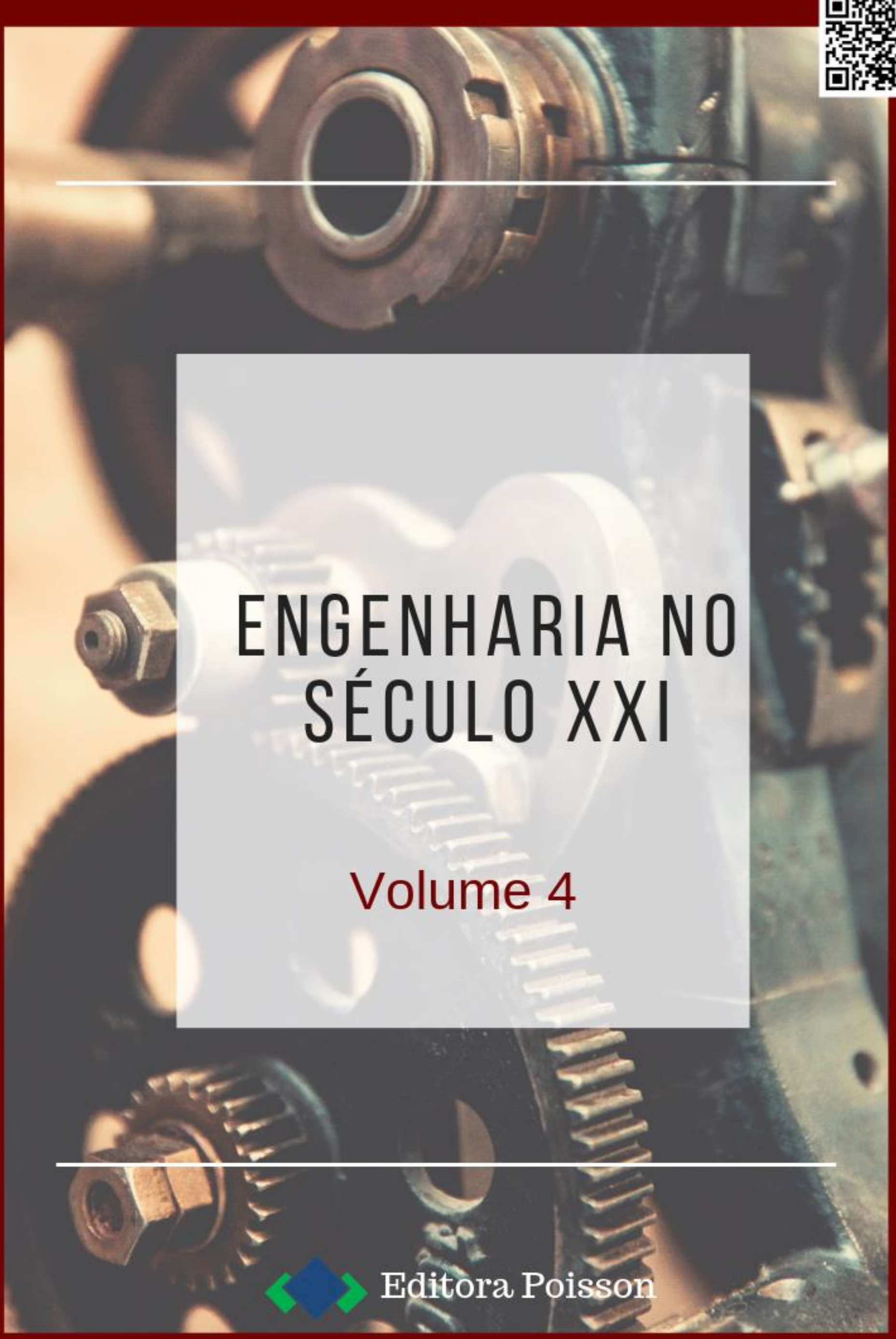


Editora Poisson

\section{Engenharia no Século XXI Volume 4}

1a Edição

Belo Horizonte

Poisson

2019 
Editor Chefe: Dr. Darly Fernando Andrade

\section{Conselho Editorial}

Dr. Antônio Artur de Souza - Universidade Federal de Minas Gerais

Msc. Davilson Eduardo Andrade

Msc. Fabiane dos Santos Toledo

Dr. José Eduardo Ferreira Lopes - Universidade Federal de Uberlândia

Dr. Otaviano Francisco Neves - Pontifícia Universidade Católica de Minas Gerais

Dr. Luiz Cláudio de Lima - Universidade FUMEC

Dr. Nelson Ferreira Filho - Faculdades Kennedy

Msc. Valdiney Alves de Oliveira - Universidade Federal de Uberlândia

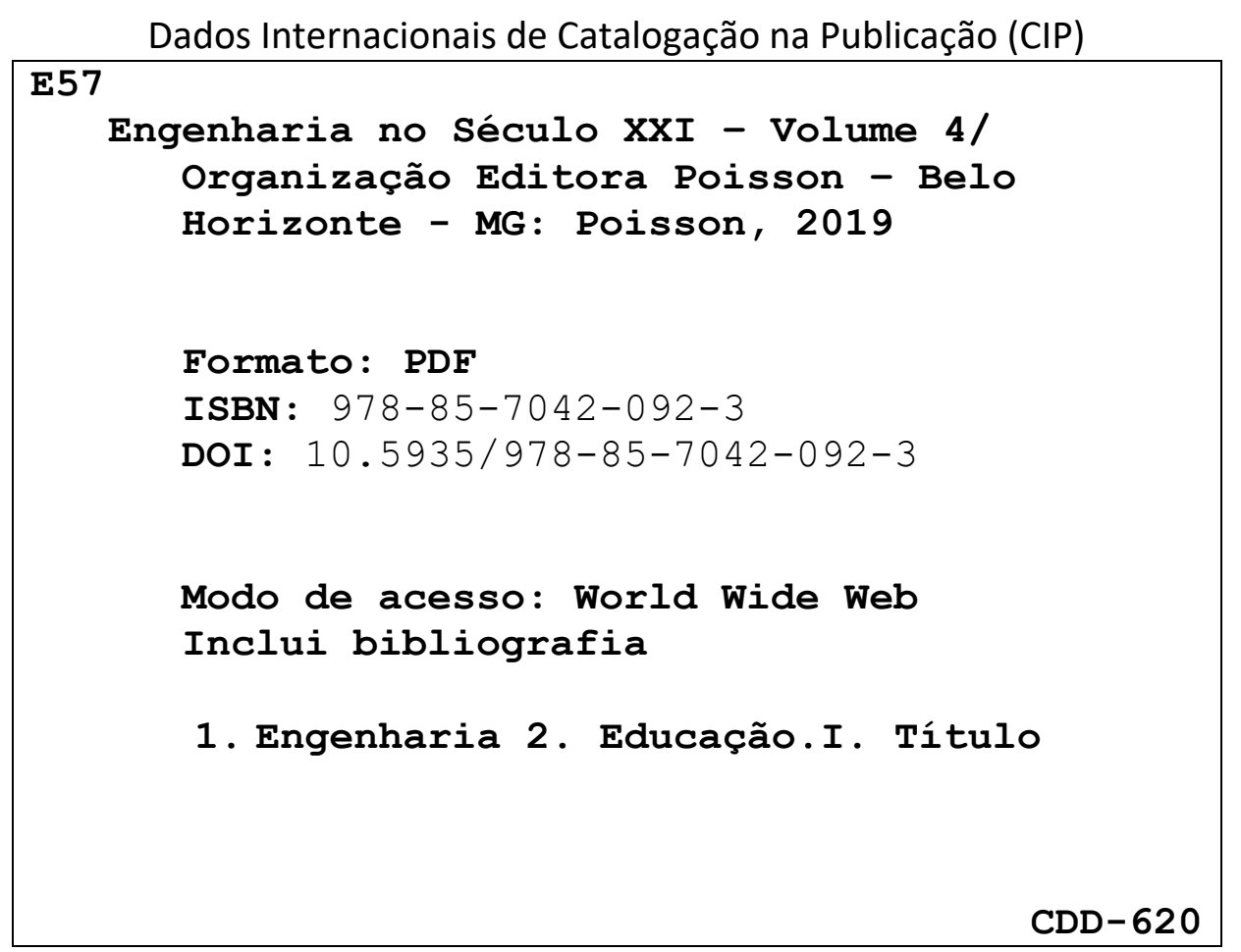

O conteúdo dos artigos e seus dados em sua forma, correção e confiabilidade são de responsabilidade exclusiva dos seus respectivos autores.

$\underline{\text { www.poisson.com.br }}$

contato@poisson.com.br 


\section{SUMÁRIO}

Capítulo 1: Influência da anisotropia no envelhecimento ambiental em plásticos reforçados por fibras de vidro

Sérgio Renan Lopes Tinô, Ana Claudia de Melo Caldas Batista, Raphael Siqueira Fontes, Eve Maria Freire de Aquino

Capítulo 2: Avaliação de procedimentos de soldagem qualificados ASME para otimizar o desempenho em corrosão de tubulações AISI 304L 14

Luis Henrique Guilherme, Ana Caroline Firmiano de Jesus, Cecílio Sadao Fugivara, Assis Vicente Benedetti

Capítulo 3: Avaliação dos fatores e das propriedades limitantes do polietileno de fonte renovável. 24

Douglas Dias de Oliveira, Giovanna Amábile Duarte Rosa, Luiz Henrique Cavalcante Damacena, Anderson Maia, Rondes Ferreira da Silva Torin

Capítulo 4: Avaliação da refrigeração criogênica na usinagem cnc do aço inoxidável martensítico AISI 440C.

Fernando Prando Dacas, Rodrigo Cardoso Costa, Elandir Antonio Desidério, Fernando Michelon Marques, Eduardo Augusto Flesch, Felipe Canal

Capítulo 5: Tratamento de Nitretação para Melhoria de Superfícies Erodidas. 38 Gustavo César Pamplona de Sousa, Marcone Andrade Farias

Capítulo 6: Desenvolvimento de equipamento para realização de ensaio de torção em eixo AISI 4340 46

Mateus Felipe Bald, Neimar João Balan, Lucas Barp, Rodrigo Cardoso Costa, David Roza José, Fernando Michelon Marques

Capítulo 7: Caracterização microestrutural, química e microdureza dos aços inoxidáveis 53

Josué Boaroli, Fernando Michelon Marques, Rodrigo Cardoso Costa, Alexandre da Silva Rocha

Capítulo 8: Caracterização e reciclagem de filmes multicamadas metalizados pósconsumo. 62

Andrea Bettanin, Ruth Marlene Campomanes Santana 


\section{SUMÁRIO}

Capítulo 9: Influência da concentração de refinador de grãos na liga de alumínio fundida A356. 70

Lucas Carvalho Cruz, Reinaldo de Almeida Rodrigues, Jonathas Santos Morais, Waldeir Santos Dias, Josiel Bruno de Oliveira, Dayane Izabelita Santos Lacerda, José Costa de Macêdo Neto

Capítulo 10: Os requisitos de scaffolds para regeneração meniscal 76

Raquel Rosa de Souza, Ênio César Machado Fagundes, Durval João De Barba Junior, Cláudia Ciceri Cesa, Thiago Farias Bujes, Carmen Iara Walter Calcagno

Capítulo 11: Alternativas para substituição de painéis de aço em vagões 84 Jean Carlo Tavares, Leandro da Conceição Medeiros

Capítulo 12: Análise de tensões geradas no contato roda/trilho através de simulações numéricas. 95

Rafael Soares Cardoso, Mateus Fortes Carvalho, Kamila da Silva Pompeu, Leonardo Dantas Rodrigues

Capítulo 13: A influência do aumento da dureza na diminuição do desgaste em um sistema tribológico de pino-sobre-disco 103

Claudio Victor da Silva e Silva, Beatriz Seabra Melo, Vinicius Silva dos Reis, Clóvis Iarlande Oliveira Santana, Emerson David Cavalcante Santos, José Maria do Vale Quaresma

Capítulo 14: Estudo da obtenção de MO2C por reação gás-sólido em reator de leito fixo e rotativo. 112

Camila Pacelly Brandão de Araújo, Carlson Pereira de Souza, Maria Veronilda Macedo Souto, Cleonilson Mafra Barbosa, Antonia Vanessa Vasconcelos Martins Frota

Capítulo 15: Effect of nitrogen treatment on $\mathrm{Nd}-\mathrm{Fe}-\mathrm{B}$ based powder 120

Marcelo Demétrio Magalhães, Juliano Assis Baron Engerroff, Paulo Antônio Pereira Wendhausen

Capítulo 16: Síntese e caracterização de óxido de Mn nanoestruturado em camada (CaOl-2) a partir de minérios da antiga mina de Serra do Navio (Amapá) 126

Irlana Costa do Mar, Bruno Apolo Miranda Figueira, Liliane Nogueira da Silva, José Manuel Rivas Mercury, Renata de Sousa Nascimento, Patrícia Teresa da Luz, Oscar Jesus Choque Fernandez 


\section{SUMÁRIO}

Capítulo 17: Influência da variação dos gases de proteção e parâmetros de soldagem na microestrutura e microdureza do aço SAE 1035 soldado por Processo MAG 131 Perla Alves de Oliveira, Thiago Monteiro Maquiné, Márcia Cristina Gomes de Araújo Lima, Reinaldo de Almeida Rodrigues, José Costa de Macedo Neto

Capítulo 18: Efeito da incorporação da enzima celulase e dos fatores abióticos na biodegradação aeróbia do PEBD

Luisa Alban, Gabriela Messias Miranda, Jéssica Pereira Pires, Gabriela Lagranha de Souza, Flávia Stürmer de Fraga , Rogério Vescia Lourega , Rosane Angélica Ligabue , Jeane Estela Ayres de Lima

Capítulo 19: Obtenção de liga de NiCu e Cu metálico com eletrodeposição pulsada variando corrente e $\mathrm{pH}$

Thayane Carpanedo de Morais Nepel, Thales Antônio Amarante, Daniella Gonçalves Portela , Ambrósio Florêncio de Almeida Neto

Capítulo 20: Caracterização mecânica e térmica de blendas de PP Virgem/PP Reciclado com destino à fabricação de para-choques 153

Wallisson Alves da Silva, Carlos Bruno Barreto Luna, João Baptista da Costa Agra de Melo, Edcleide Maria Araújo

Capítulo 21: Eletrofiação de poli ( $\varepsilon$-caprolactona) contendo óleo de andiroba (carapa guianensis aublet)

Tainah Vasconcelos Pessoa, João de Deus Pereira de Moraes Segundo, Maria Oneide Silva de Moraes, Rosemeire dos Santos Almeida, Marcos Akira d’Ávila, Karen Segala, Walter Ricardo Brito, Rudyere Nascimento Silva 


\section{Capítulo 1}

Influência da anisotropia no envelhecimento ambiental em plásticos reforçados por fibras de vidro

\section{Sérgio Renan Lopes Tinô \\ Ana Claudia de Melo Caldas Batista \\ Raphael Siqueira Fontes \\ Eve Maria Freire de Aquino}

Resumo: As respostas dos compósitos estão diretamente relacionadas com seus constituintes e principalmente com a distribuição e a orientação das fibras com relação à direção de aplicação da carga (anisotropia). A propriedade de anisotropia torna-se, inclusive, um limitante em termos de aplicação para os materiais compósitos na forma de estrutura laminar. Aliado a este fator, diversas aplicações de PRFV exigem resistência à exposição de intempéries. Buscando analisar as influências da anisotropia e da integridade estrutural frente às intempéries, neste trabalho, analisa-se um laminado compósito envolvendo a presença de quatro camadas de tecido bidirecional de fibra de vidro/E e impregnadas com resina de poliéster orto-tereftálica. Duas configurações, direções $0 / 90^{\circ}$ e $\pm 45^{\circ}$, são avaliadas pela Técnica de Medição de Variação de Massa (TMVM) e Técnica de Medição de Variação de Espessura (TMVE). Percebe-se uma boa aproximação entre a TMVM e TMVE.

Palavras-chaves: PRFV, envelhecimento ambiental, anisotropia. 


\section{INTRODUÇÃO}

Os materiais compósitos poliméricos a base de fibras de vidro, também denominados de Plástico Reforçados de Fibras de Vidro (PRFV), são afetados por vários fatores que influenciam nas propriedades mecânicas em geral, como: processo de fabricação, orientação da fibra com relação à direção da carga aplicada (anisotropia), configuração do compósito, percentual e tipo de fibra, percentual e tipo de resina, formas de carregamentos, mecanismo de dano, a qualidade da interface entre fibra/matriz e/ou entre as camadas de um laminado, a presença de condições adversas de umidade e temperaturas e principalmente as propriedades dos elementos constituintes (1-5).

Um dos tecidos mais utilizados como reforço para os materiais compósitos é o bidirecional, seja com as fibras orientadas a $0 / 90^{\circ}$ ou a $\pm 45^{\circ}$ com relação à aplicação da carga. Neste último caso, inclusive, quando impregnado em uma matriz recebe o nome de compósito equiangular $(1,6)$. Quando o material compósito apresenta fibras orientadas a $0 / 90^{\circ}$, num ensaio de tração uniaxial essas tensões são passadas à fibra, enquanto que para o laminado compósito equiangular sob um carregamento de tração uniaxial, o laminado fica submetido diretamente às direções em que atuam as tensões cisalhantes (7).

No que diz respeito à influência do envelhecimento ambiental em compósitos poliméricos pode ocorrer à degradação da matriz polimérica, do reforço ou do sistema como um todo. Em termos de condições de serviços, na ausência de qualquer forma radiação e/ou operando à temperatura ambiente, a maioria dos polímeros apresentam-se estáveis por longos períodos de tempo. No entanto, sob a luz do sol (radiação UV) a taxa de oxidação dos polímeros é acelerada e este efeito pode ser exacerbado pela presença de poluentes atmosféricos, como o nitrogênio e óxidos de enxofre, que são componentes frequentes em atmosferas industriais (8).

Logo, o presente trabalho estuda a influência do efeito do envelhecimento ambiental (Vapor aquecido e radiação UV) sob a integridade estrutural de um laminado compósito polimérico reforçado com tecido bidirecional de fibras de vidro/E, levando em conta a propriedade da anisotropia, ou seja, considerando diferentes direções das fibras (no corte dos corpos de prova), mais especificamente com fibras a $0 / 90^{\circ} \mathrm{e}$ $\pm 45^{\circ}$. Este estudo se dá a partir das técnicas experimentais de medição de perdas de massa e espessura, definidas como TMVM e TMVE, respectivamente.

\section{MATERIAIS E MÉTODOS}

\subsection{MATERIAIS UTILIZADOS E CONFIGURAÇÃO DO LAMINADO}

O laminado compósito proposto para estudo é constituído por um reforço de quatro camadas do tecido bidirecional (balanceado) de fibra de vidro-E com uma gramatura de $600 \mathrm{~g} / \mathrm{m} 2$ (fabricado pela empresa TEXIGLASS, de nome comercial WR-600/3-1) e como matriz foi utilizado a resina de poliéster insaturada orto-tereftálica, com especificação técnica Novapol - L120. 0 laminado compósito foi estudado para dois tipos de corpos de prova (CP's), cujas configurações são definidas como $0 / 90^{\circ}$ e $\pm 45^{\circ}$. A Fig. 1 ilustra a configuração do laminado, aqui definido como LT, e as direções que os CP's foram cortados. Ressalta-se que a camada de resina é apenas uma representação, já que as mesmas são impregnadas diretamente nas camadas de reforço do laminado. 
Fig. 1. Configuração do laminado compósito polimérico LT e dos CP's $0 / 90^{\circ} \mathrm{e} \pm 45^{\circ}$.

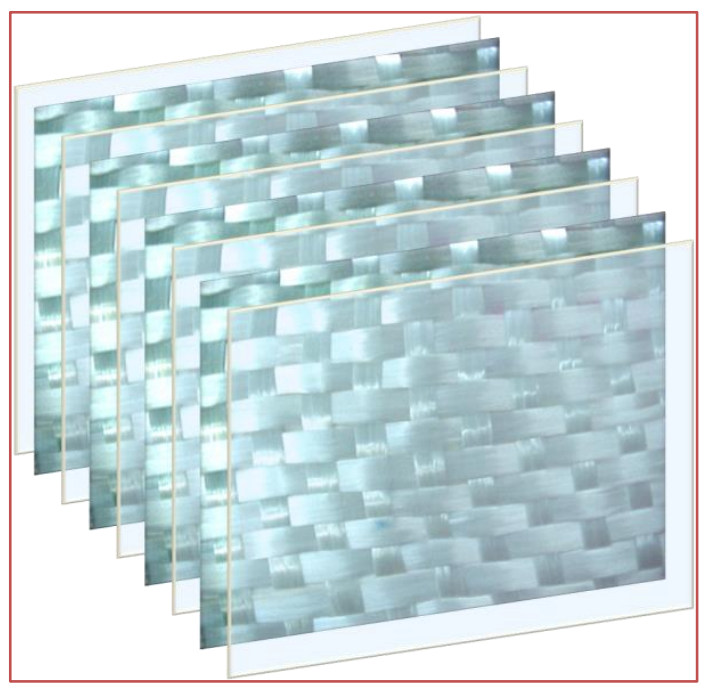

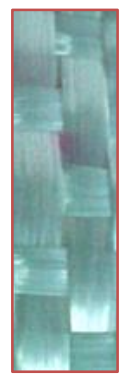

Corpos de prova $0 / 90^{\circ}$

Onde:
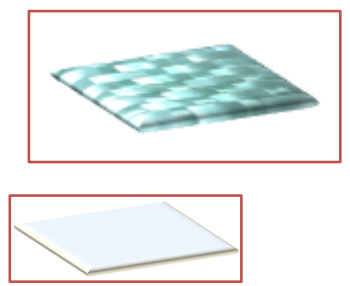

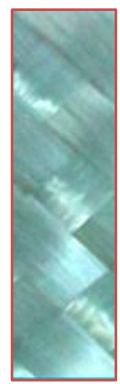

Corpos de prova $\pm 45^{\circ}$

Tecido bidirecional (balanceado) de fibra de vidro/E.

Resina

\subsection{ENSAIO DE ENVELHECIMENTO AMBIENTAL ACELERADO}

De acordo com a norma ASTM G-53 (9), foi construída uma câmara de envelhecimento ambiental acelerado, ver figura 2, na qual os CP's foram ensaiados nas condições de ciclos alternados, diários de radiação UV (18 horas) e vapor d'água aquecido (6 horas) até atingir o tempo definido através da norma ASTM G154 (10) de 2016h de exposição no total.

Fig. 2: Câmara de envelhecimento ambiental acelerado.

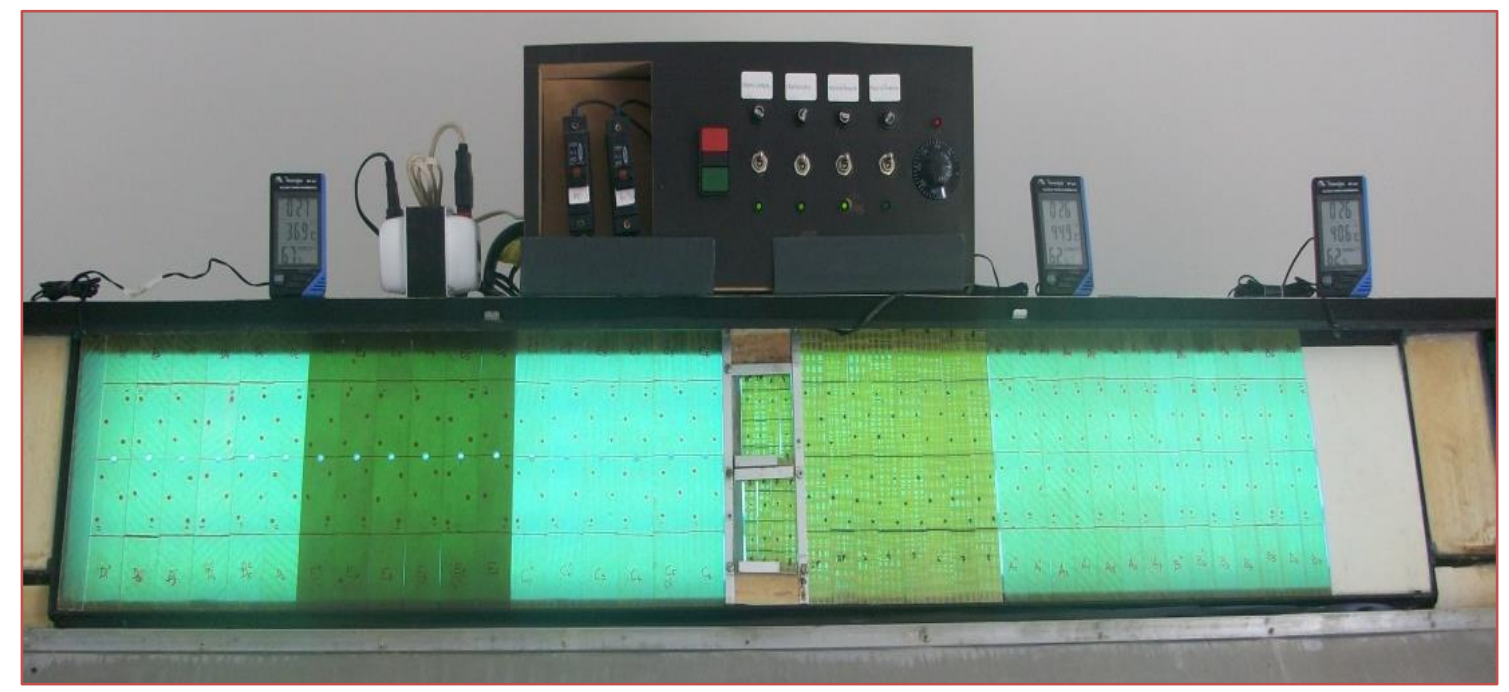




\subsection{TÉCNICA DE EXPERIMENTAIS DE MEDIÇÃO - TMVM E TMVE}

A avaliação da estabilidade estrutural, em termos de degradação, foi realizada utilizando duas formas distintas de medição, que são: Técnica de Medição de Variação de Massa (TMVM) e a Técnica de Medição Variação de Espessura (TMVE), técnica está desenvolvida por $(8,11)$.

A TMVM é baseada na lei de difusão de Fick, consiste em quantificar as perdas de massas. As variações de perda de massa são obtidas pela Eq. (A).

$$
\Delta M=\frac{M_{\text {envelhecida }}-M_{\text {original }}}{M_{\text {original }}}
$$

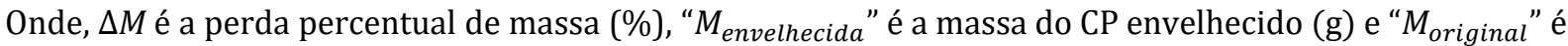
a massa do CP no estado original (g). As medidas foram efetuadas em intervalos de 7 (sete) dias e sempre após ciclo de radiação UV.

A TMVE objetiva detectar variação de espessura na secção transversal dos CP's, mediante a utilização do micrômetro. Para tanto, foram feitas marcações (pontos ao longo do comprimento útil dos corpos de prova), servindo essas marcações como referência. Desta forma, foram realizadas medições da espessura antes e após a finalização do período de exposição dos CP’s na câmara de envelhecimento.

\section{RESULTADOS E DISCUSSÃo}

\subsection{INTEGRIDADE ESTRUTURAL DO LT DIREÇÃO 0/90}

Para a análise da TMVE realizou-se as medidas de espessura dos CP's LT 0/90 (antes do processo de envelhecimento) e dos CP's LTE $0 / 90^{\circ}$ (após o envelhecimento ambiental acelerado), resultados mostrados na Fig. 3 a. Analisando os dados observa-se os CP's LTE 0/90 obteve uma redução de 0,028 $\mathrm{mm}$ o que corresponde a uma perda de $0,82 \%$ (em diferença absoluta).

Para a TMVM, a variação de massa ocorrida nos CP's LTE $0 / 90^{\circ}$ pode ser observada na Fig. 3 b. Percebe-se que no comportamento da perda de massa em função do tempo se constata que os CP's iniciaram a perda de massa a partir do $14^{\circ}$ dia (aproximadamente $336 \mathrm{~h}$ ) de exposição e que as perdas de massas mais expressivas se deram entre os dia $14^{\circ}$ e $42^{\circ}$ onde verificou-se quase $0,5 \%$ de perda. Enquanto que no final do processo (84 dias) essa perda total chegou a 0,72\% e dispersão absoluta de 5,2 \%.

Fig. 3. (a) resultado obtidos pela TMVE; (b) Resultados obtidos pela TMVM.

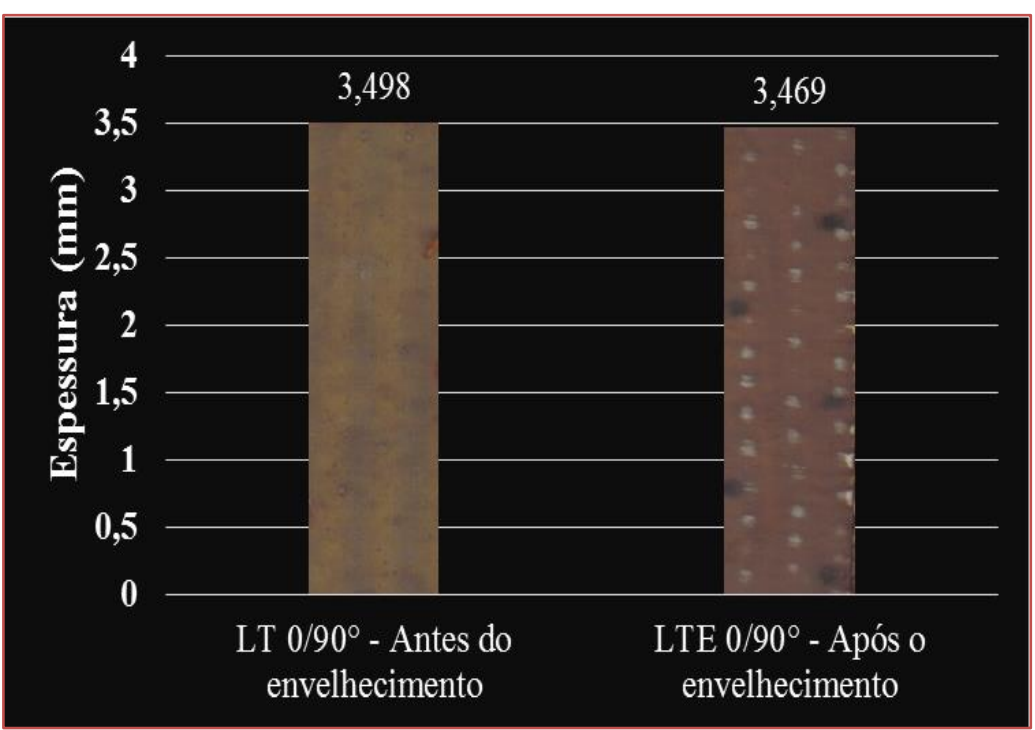

(a) 


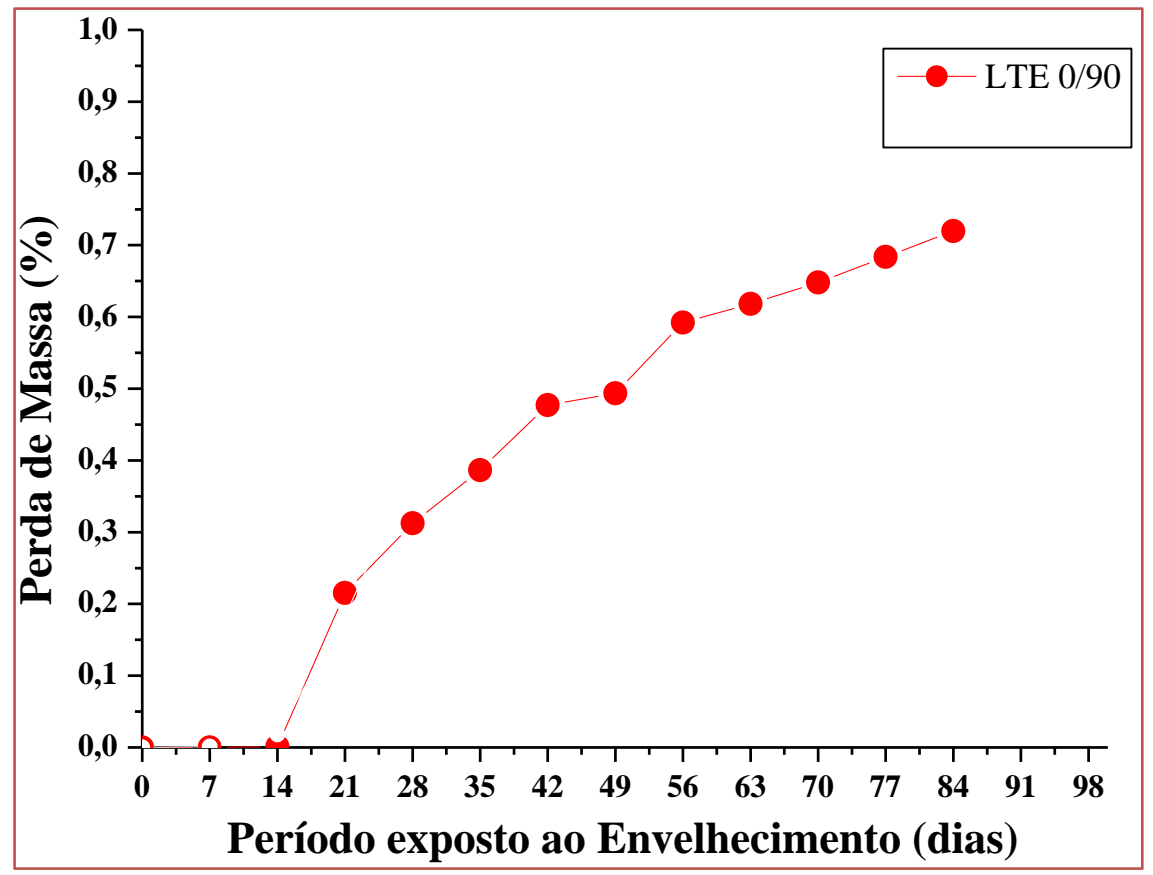

(b)

\subsection{INTEGRIDADE ESTRUTURAL DO LT DIREÇÃO $\pm 45^{\circ}$}

Mesmo procedimento descrito anteriormente foi usado para a TMVE nos CP's com direção das fibras à $\pm 45^{\circ}$. Para os CP's LTE $\pm 45^{\circ}$ (após o envelhecimento) observou-se uma redução na espessura de 0,032 $\mathrm{mm}$, se calculado a diferença da espessura obtida antes do processo de envelhecimento (CP's LT $\pm 45^{\circ}$ ). Esses resultados são mostrados na Fig. 4 a. Isto representa uma perda de espessura de 0,78\%.

Pela TMVM (ver Fig. 4 b), o início da instabilidade ocorreu a partir do $14^{\circ}$ dia e as perdas de massa mais expressivas ocorreram entre os dias $14^{\circ}$ e $42^{\circ}$, tendo uma perda de aproximadamente $0,45 \%$, comportamento este, similar ao obtido para os CP's LTE $0 / 90^{\circ}$. Ao final do $84^{\circ}$ dia a perda de massa foi de $0,64 \%$ com uma dispersão absoluta de $4,9 \%$. Pode-se dizer que a anisotropia (direção distintas das fibras) influenciou no processo de instabilidade estrutural, sendo a direção $0 / 90^{\circ}$ a mais afetada pelo envelhecimento ambiental acelerado no tocante as perdas de massa e espessura.

Fig. 4. (a) resultado obtidos pela TMVE; (b) Resultados obtidos pela TMVM.

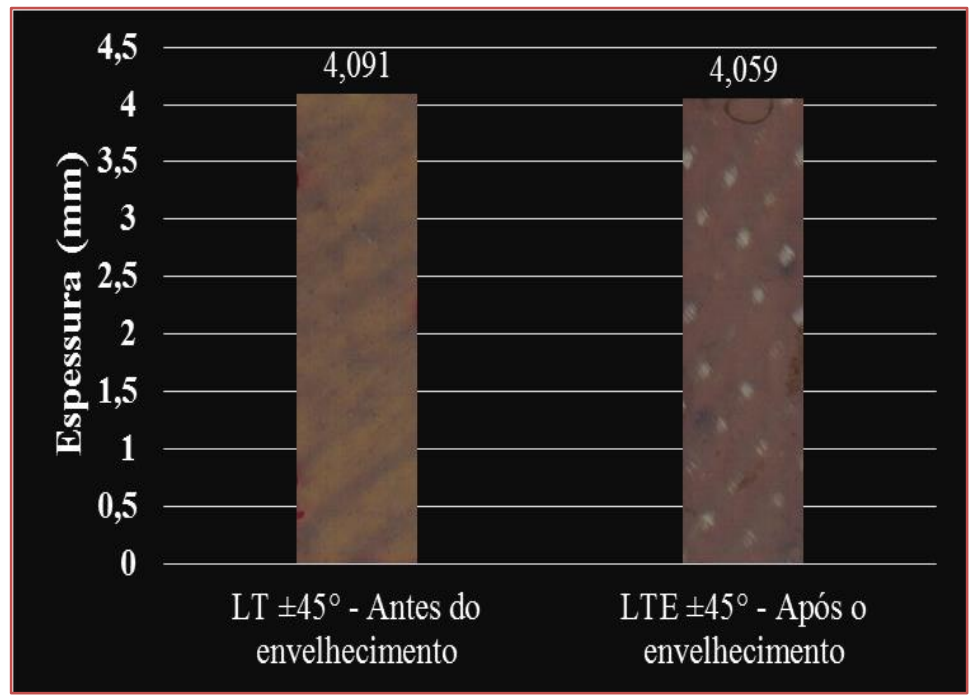

(a) 


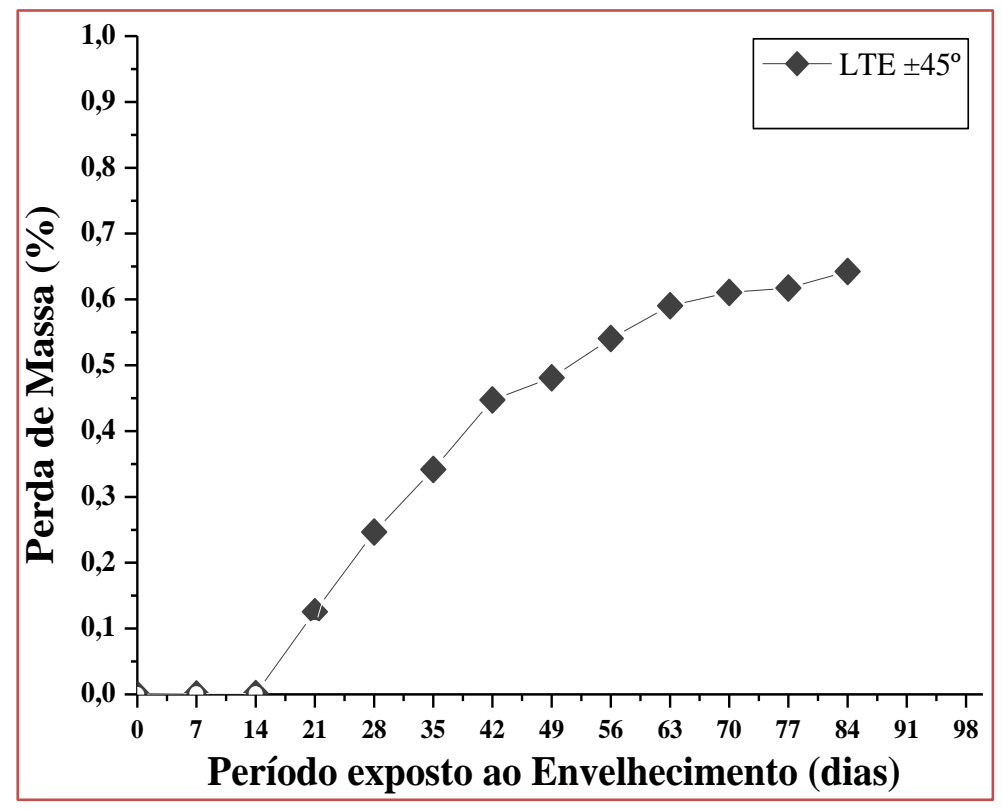

(b)

\subsection{COMPARATIVO GLOBAL}

Pode-se dizer que em relação a TMVE houve superioridade de 5\% dos CP's LTE 0/90 comparado aos CP's LTE $\pm 45^{\circ}$, enquanto para a TMVM a diferença percentual foi de $11 \%$, ver Fig. 5 . Ressalta-se que a influência da configuração foi mais significativo quando comparado em termos de perda de massa, acrescido a isto, os $\mathrm{CP}^{\prime} \mathrm{s}$ na direção $0 / 90^{\circ}$ sempre tiveram maiores perdas, independente da técnica utilizada.

Fig. 5. Comparativo global de perda entre a TMVE e a TMVM.

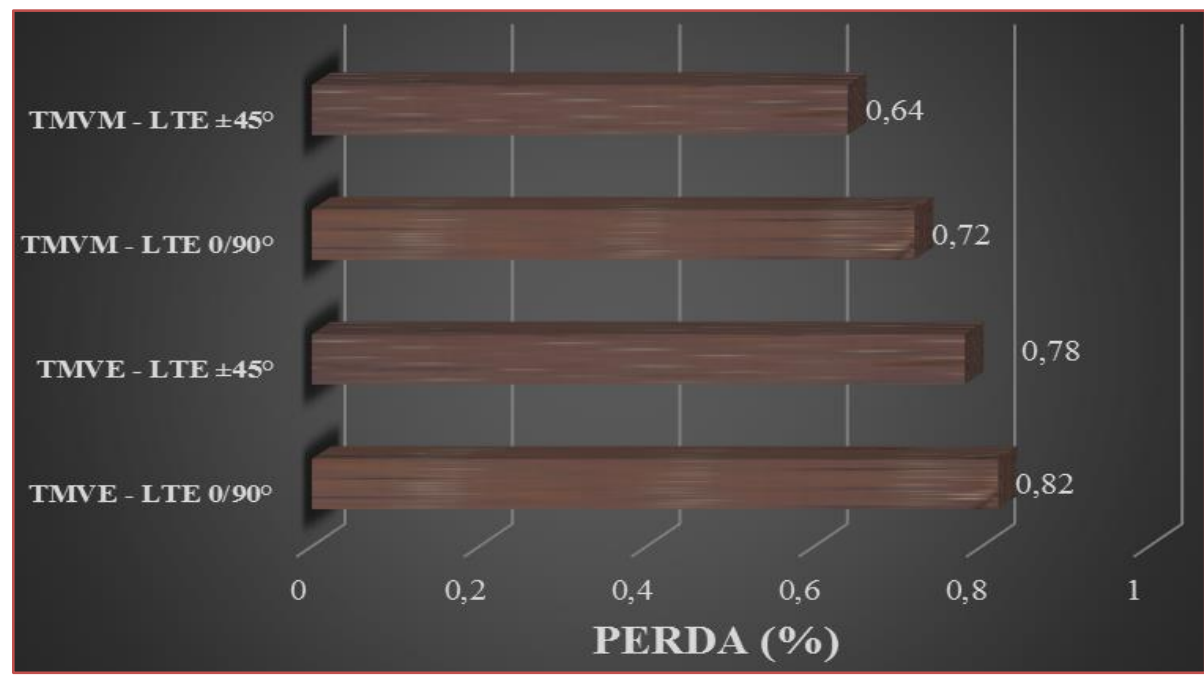

Ainda em relação a Fig. 5, para os CP's LTE $0 / 90^{\circ}$ a TMVE foi superior a TMVM em $12 \%$, já para os CP's LTE $\pm 45^{\circ}$ foi de $18 \%$, ou seja, independente da configuração a TMVE aferiu valores sempre maiores quando comparados com a perda de massa.

\section{CONCLUSÕES}

Numa análise dos resultados obtidos pode-se concluir que: Tanto os CP's LTE 0/90 quanto os CP's LTE $\pm 45^{\circ}$ variaram de espessura; as técnicas (TMVE e TMVM) utilizadas para analisar a instabilidade 
estrutural são coerentes; a anisotropia (a direção das fibras) influenciou no processo de instabilidade estrutural, sendo a direção $0 / 90^{\circ}$ a mais afetada pelo envelhecimento ambiental acelerado no tocante as perdas de massa e espessura; e a TMVE facilita a análise da integridade estrutural ocorrida no laminado após envelhecimento, uma vez que a sua medição se verifica apenas no final do ensaio.

\section{AGRADECIMENTOS}

Agradecimentos ao suporte financeiro (bolsas) proveniente do CNPq e ao Congresso Brasileiro de Engenharia e Ciência dos Materiais (CBECIMAT 2016) pela publicação em seus anais de congresso.

\section{REFERÊNCIAS}

[1] HERAKOVICH, C. T. Mechanics of fibrous composite. Ed. Wiley: New York, 460p, 1997.

[2] AQUINO, E. M. F.; FREIRE JÚNIOR, R. C. S. Fatigue Damage Mechanism and Failure Prevention in Fiberglass Reinforced Plastic. Materials Research , v. 8, n. 1, p. 45-49, 2005.

[3] FREIRE JÚNIOR, R. C. S.; DÓRIA NETO, A. D.; AQUINO, E. M. F. Comparative study between ANN models and conventional equations in the analysis of fatigue failure of GFRP. International Journal of Fatigue, v. 31, p. 831-839, 2009.

[4] SILVA, R.V.; AQUINO, E.M.F.; RODRIGUES, L.P.S.; BARROS, A.R.F. Curaua/Glass Hybrid Composite: The Effect of Water Aging on the Mechanical Properties. Journal of Reinforced Plastics and Composites, v. 28, p. 1857-1868, 2009.

[5] TINÔ, S.R.L.; FONTES R.S.; AQUINO, E.M.F. Theories of failure average stress criterion and point stress criterion in notched fiber-reinforced plastic. Journal of Composites Materials, Vol. 31, n.1 , 2013.

[6] HULL, D. An Introduction to Composite Materials. Cambridge University Press: Cambridge, 1988.

[7] HUFNER, D.R.; ACCORSI, M.L. A progressive failure theory for woven polymer-based composites subjected to dynamic loading. Composite Structures, v. 89, p. 177-185, 2009.

[8] FELIPE, R.C.T.S. Envelhecimento Ambiental Acelerado em PRF a Base de Tecidos Híbridos Kevlar/Vidro: Propriedades e Instabilidade Estrutural. 2012(a),189p. Tese (doutorado em Engenharia Mecânica), UFRN, Natal-RN.

[9] ASTM G53. Standard Practice for Operating Light- and Water- Exposure Apparatus (Fluorescente UVCondensation Type) for Exposure of Nonmetallic Materials, ASTM International, Philadelphia,1996.

[10] ASTM G154. Standard Practice for Operating Fluorescent Light Apparatus for UV Exposure of Nonmetallic Materials, ASTM International, Philadelphia, 2006.

[11] FELIPE, R.N.B. Efeitos da Radiação UV, Temperatura e Umidade nos PRF: Modelagem, Instabilidade Estrutural e Fratura, 2012(b), 247p. Tese (doutorado em Engenharia Mecânica), UFRN, Natal-RN. 


\section{Capítulo 2}

Avaliação de procedimentos de soldagem qualificados ASME para otimizar o desempenho em corrosâo de tubulações AISI $304 \mathrm{~L}$

\section{Luis Henrique Guilherme \\ Ana Caroline Firmiano de Jesus \\ Cecílio Sadao Fugivara \\ Assis Vicente Benedetti}

Resumo: 0 presente estudo teve por objetivo avaliar diferentes procedimentos de soldagem TIG para otimizar o desempenho de tubulações AISI 304L em aplicações corrosivas. Para tanto, produziu-se amostras soldadas pelo processo TIG onde a variável foi a densidade de corrente elétrica: usou-se corrente constante e corrente no modo pulsado. 0 comportamento eletroquímico das juntas soldadas foi avaliado pela técnica de polarização potenciodinâmica e pela técnica de reativação potenciocinética de duplo pulso. A caracterização microestrutural e da área exposta à varredura foi realizada por microscopia ótica e microscopia eletrônica de varredura. Os resultados indicaram que o processo TIG pulsado $250 \mathrm{~Hz}$ obteve os parâmetros eletroquímicos mais nobres, e atribuiu-se a melhor performance ao associar baixa densidade de corrente média e elevada velocidade de soldagem.

Palavras Chave: Comportamento eletroquímico, minicélula eletroquímica, TIG pulsado, tubulação AISI 304L, processos assépticos 


\section{INTRODUÇÃO}

Tubulação industrial é uma parte fundamental para processos químicos de transformação e há aplicações com alta exigência sob requisito de resistência à corrosão e assepsia nos mais variados segmentos (farmacêutico, químico, petroquímico, alimentício, bebidas, biotecnologia) (1-2).

Uma especificação de procedimento de soldagem (EPS) define uma ampla faixa de ajuste para os parâmetros de soldagem TIG de tubulações, onde o foco tem sido a resistência mecânica da junta soldada. No entanto, a configuração do procedimento de soldagem gera a história térmica a ser aplicada na junta soldada, onde o ciclo térmico, a repartição térmica e as linhas isotermas definirão o comportamento no que se refere a solidificação e precipitação de fases na junta soldada e, consequentemente, seu comportamento eletroquímico (3-6).

Para contribuir com a literatura nessa direção, o presente trabalho teve por objetivo avaliar procedimentos de soldagem TIG com corrente constante e no modo pulsado sob requisitos de resistência à corrosão. Para tanto, técnicas eletroquímicas usando uma minicélula foram utilizadas para avaliar a resistência à corrosão da junta soldada, e microscopia ótica e eletrônica de varredura foram conduzidas para avaliar a microestrutura da junta soldada. Os parâmetros de soldagem foram obtidos a partir de especificações de procedimentos de soldagem (EPS) qualificados segundo ASME seção IX.

\section{MATERIAIS E MÉTODOS}

O metal de base usado foi o tubo de aço inoxidável AISI 304L padrão OD polido internamente para aplicação asséptica com diâmetro externo de seis (6) polegadas e espessura de parede de $2.0 \mathrm{~mm}$. 0 metal de solda foi obtido pela fusão causada pelo arco eletrico das partes metálicas a serem unidas (metal de base), sem a deposião de metal de solda, operação denominada autógena. A Tabela 1 mostra a composição química do metal de base de acordo com o certificado de qualidade do fabricante.

Tabela 1. Composição química do tubo OD AISI 304L.

\begin{tabular}{|c|c|c|c|c|c|c|c|c|c|c|c|}
\hline \multirow{10}{*}{ Amostra } & \multicolumn{10}{c|}{ Elementos (\% em peso) } \\
& $\mathrm{C}$ & $\mathrm{Cr}$ & $\mathrm{Ni}$ & $\mathrm{Mo}$ & $\mathrm{Mn}$ & $\mathrm{Si}$ & $\mathrm{P}$ & $\mathrm{S}$ & $\mathrm{Cu}$ & $\mathrm{Ti}$ & $\mathrm{Fe}$ \\
\hline AISI304L & 0,02 & 18,12 & 8,00 & 0,085 & 1,14 & 0,41 & 0,031 & 0,002 & 0,1932 & 0,0035 & Bal. \\
\hline
\end{tabular}

A indústria metal-mecânica utiliza amplamente os tubos de aço inoxidável padrão OD de parede fina na interligação de equipamentos de processo, e sua montagem normalmente é feita pela técnica popularmente denominada como "bocal colado". Para esse estudo a preparação das amostras se deu pelo ajuste mecânico da face do tubo por uma máquina faceadora de tubos AXXAIR DC65, com posterior montagem das partes de tubo a serem soldadas em uma junta de topo sem abertura (Figura 1). Um cuidadoso ponteamento foi realizado em oito pontos distribuídos pelo perímetro do tubo sem que houvesse a penetração do ponto de solda (pré-montagem pela fusão da superfície externa), utilizando arame AWS ER308L diâmetro $1.2 \mathrm{~mm}$.

Figura 1. Desenho esquemático de preparação do corpo de prova.

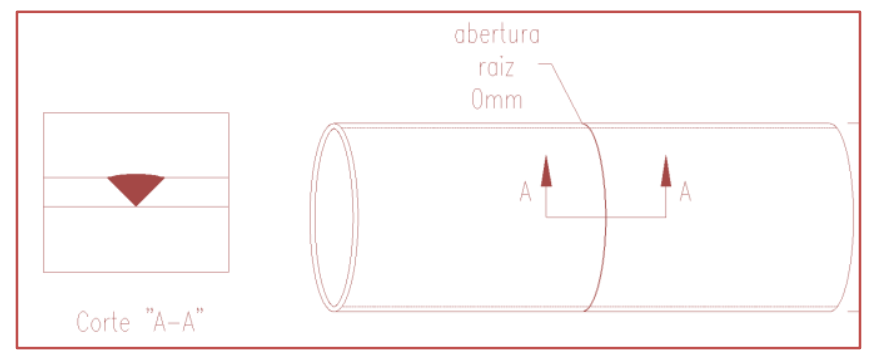

A soldagem das amostras foi realizada por quatro (4) distintos procedimentos de soldagem, conforme descrito abaixo e parâmetros apresentados na Tabela 2 : 
- Soldagem TIG corrente constante: Aplicação de corrente contínua e polaridade direta para um ajuste de corrente constante $(75 \mathrm{~A})$.

- Soldagem TIG pulsado $1 \mathrm{~Hz}$ : Aplicação de corrente modo pulsado e forma de onda de $50 \%$ entre a corrente de pico e a corrente de base. Para esse procedimento usou-se a frequência de pulso de $1 \mathrm{~Hz}$.

- $\quad$ Soldagem TIG pulsado $40 \mathrm{~Hz}$ : Semelhante ao procedimento descrito em (2), com alteração da frequência de pulso para $40 \mathrm{~Hz}$.

- $\quad$ Soldagem TIG pulsado $40 \mathrm{~Hz}$ : Semelhante ao procedimento descrito em (2), com alteração da frequência de pulso para $250 \mathrm{~Hz}$.

Tabela 2. Parâmetros de soldagem TIG.

\begin{tabular}{|c|c|c|c|c|c|c|}
\hline $\begin{array}{c}\text { Procedimento de } \\
\text { soldagem }\end{array}$ & $\begin{array}{c}\text { Corrente de } \\
\text { base (A) }\end{array}$ & $\begin{array}{c}\text { Corrent de } \\
\text { pico (A) }\end{array}$ & $\begin{array}{c}\text { Frequência } \\
\text { de pulso / } \\
\text { onda }\end{array}$ & Tensão (V) & $\begin{array}{c}\text { Velocidade } \\
\text { de soldagem } \\
\text { (mm/min) }\end{array}$ & $\begin{array}{c}\text { Heat input } \\
(\mathrm{KJ} \text { mm-1) }\end{array}$ \\
\hline $\begin{array}{c}\text { TIG corrente } \\
\text { constante }\end{array}$ & \multicolumn{2}{|c|}{$75 \pm 1$} & n.a. & $12.2 \pm 1$ & 131.93 & 0.42 \\
\hline TIG pulsado $1 \mathrm{~Hz}$ & $20 \pm 1$ & $85 \pm 1$ & $1 / 0,5$ & $12.1 \pm 1$ & 59.62 & 0.64 \\
\hline TIG pulsado $40 \mathrm{~Hz}$ & $20 \pm 1$ & $85 \pm 1$ & $40 / 0,5$ & $12.1 \pm 1$ & 63.65 & 0.60 \\
\hline TIG pulsado $250 \mathrm{~Hz}$ & $20 \pm 1$ & $85 \pm 1$ & $250 / 0,5$ & $12.1 \pm 1$ & 96.71 & 0.39 \\
\hline
\end{tabular}

Distância bico de contato-peça (DBCP): $10 \pm 1 \mathrm{~mm}$.

Gás de proteção / Vazão / Polaridade: 99.9\% Ar / 15 L min-1 / CCPD(-).

Para o procedimento de soldagem TIG pulsado a corrente média (Im) é a média ponderada das correntes de pulso e de base, assumindo-se um formato de onda regular (50\%), expresso pela equação A. Sendo que Im pode ser, para efeito de análise, comparada à corrente média de soldagem do procedimento TIG corrente constante. 0 controle da transferência metálica é dado pela relação Ip x tp, uma vez que o fator governante para a coalescência dos metais no modo pulsado está relacionado à energia gasta durante o pulso (proporcional ao produto da amplitude da corrente de pulso e pela sua duração). 0 aporte térmico foi calculado de acordo com a definição do código ASME seção IX exposta pela equação B (7).

$$
I_{m}=\frac{\left(I_{p} t_{p}+I_{b} t_{b}\right)}{\left(t_{p}+t_{b}\right)}(\mathrm{A})
$$

Onde:

$I_{m}$ : corrente média de soldagem; $I_{p}$ : corrente de pulso; $I_{b}$ : corrente de base; $t_{p}$ : tempos de pulso; $t_{b}$ : tempos de base.

$$
E=\frac{A \cdot V}{V S}(\mathrm{~B})
$$

Onde: $E$ : aporte térmico; $A$ : densidade de corrente; $V$ : tensão do arco elétrico; $V s$ : velocidade média de soldagem.

A caracterização microestrutural e os ensaios eletroquímicos foram realizados através da vista transversal da solda conforme corte AA' da Figura 1. Para tanto, as amostras foram embutidas em resina epoxy, lixadas e polidas conforme segue: (a) para microscopia ótica (MO) e microscopia electronica de varredura (MEV) conduziu-se o lixamento até a lixa 2000 grit e o polimento em solução com pasta de diamante em suspensão com granulometria de $6 \mu \mathrm{m}, 3 \mu \mathrm{m}$ e $1 \mu \mathrm{m}$; (b) para os ensaios eletroquímicos o lixamento foi conduzido até a lixa 2000 grit. 
A análise microestrutural por MO foi obtida utilizando-se o microscópio metalográfico trinocular XJM 902, onde as amostras tiveram a microestrutura revelada através do uso de solução água régia, e no MEV utilizou-se da técnica de elétrons retroespalhados sem ataque.

Para os ensaios eletroquímicos foi utilizada uma minicélula construída pelo grupo de pesquisa (8-9) com uma área exposta a varredura de 2,5x10-2 cm-2 ( $\varnothing 1.7 \mathrm{~mm})$. Com o uso de um potenciostato EG\&G mod. Princeton Applied Reserach 283 (software Power Suite) aplicou-se duas técnicas eletroquímicas para avaliar o comportamento da junta soldada: (i) técnica de polarização potenciodinâmica; (ii) técnica de reativação potenciocinética de duplo ciclo (DL-EPR). As microrregiões de interesse foram a linha de fusão e a zona fundida da solda.

Conduziu-se a polarização potenciodinâmica em $3.5 \% \mathrm{NaCl}$ a $25{ }^{\circ} \mathrm{C}$, onde o potencial de pite (Epit) foi o principal parâmetro eletroquímico de interesse. As medidas foram realizadas a partir de $-50 \mathrm{mV}$ vs. EOCP até $+1000 \mathrm{mV}$ ou até obter o potencial de pite (Epit), com velocidade de varredura de $1 \mathrm{mV} / \mathrm{s}$, em triplicata.

Nos testes DL-EPR foram usados a solução de $0.5 \mathrm{M} \mathrm{H} 2 \mathrm{SO} 4+0.01 \mathrm{M} \mathrm{KSCN}$ a temperatura de $25^{\circ} \mathrm{C}$, que teve como parâmetro eletroquímico de interesse o grau de sintetização (DOS - degree of sensitization). 0 teste foi configurado para varrer a faixa de pontencial de $-0.5 \mathrm{~V}$ à $+0.2 \mathrm{~V}$, retornando ao potencial $-0.5 \mathrm{~V}$, com taxa de varredura de $1.67 \mathrm{mV} / \mathrm{s}$, em triplicata. Inspeção por MO da área molhada (área exposta à varredura) foi feita após cada teste DL-EPR.

\section{RESULTADOS E DISCUSSÃO}

A microestrutura do metal de base AISI 304L é tipicamente austenítica, contudo, a zona fundida da solda possui fração volumétrica de ferrita-delta $(\delta)$, importante microconstituinte para se evitar a trinca de solidificação(6), e o teor de ferrita- $\delta$ de cada amostra soldada é mostrado na Tabela 3.

Tabela 3. Teor de ferrita- $\delta$ medido por ferritoscópio.

\begin{tabular}{|c|c|}
\hline Soldagem TIG & $\delta(\%)$ \\
\hline Corrente constante $90 \mathrm{~A}$ & $11.1 \pm 0.3$ \\
\hline Pulsado $1 \mathrm{~Hz}$ & $10.6 \pm 0.2$ \\
\hline Pulsado $40 \mathrm{~Hz}$ & $10.4 \pm 0.3$ \\
\hline Pulsado $250 \mathrm{~Hz}$ & $9.3 \pm 0.2$ \\
\hline
\end{tabular}

A caracterização microestrutural por microscopia ótica (MO) indicou que a amostra soldada pelo processo TIG corrente constante obteve a partir de linha de fusão, ao ser fundido o metal de base pelo arco elétrico, uma solidificação com a presença dos microconstituintes $\gamma$ e $\delta$. A solidificação incia-se pela porção do metal de base fundido com presença de fase liquída nos contornos de grãos da ZTA (5), e foi observado a morfologia de ferrita acicular (Fig. 2.a) a partir da linha de fusão e, devido a menor taxa de resfriamento no centro do cordão de solda, ocorreu o crescimento da ferrita com morfologia dendrítica na região central da zona fundida da solda (Fig. 2.b). Importante ressaltar uma relevante coesão para um crescimento epitaxial entre a ferrita acicular e a ferrita dentrítica, fator que tende a maximizar fenômenos como crescimento de grão e microsegregação.

As amostras soldadas pelo processo TIG pulsado (independente da frequência de pulso) apresentam diferenças microestruturais principalmente na microrregião da linha de fusão. A transferência metálica que utilizou frequência de $1 \mathrm{~Hz}$ apresentou a maior coesão entre os grãos equiaxiais do metal de base, a ferrita acicular nucleada na microrregião da linha de fusão e a ferrita na forma dendrítica que nucleou e cresceu em direção ao centro da zona fundida da solda. Essa coesão foi atribuída a mais baixa velocidade média de soldagem e velocidade de solidificação, uma vez que com o aumentar da frequência de pulsação ( $40 \mathrm{~Hz}$ e $250 \mathrm{~Hz}$ ) e consequente aumento da velocidade de soldagem, o crescimento epitaxial se tornou menos regular e passou a ser observado um crescimento competitivo entre grãos da linha de fusão (Fig. 2.d para $40 \mathrm{~Hz}$ e Fig. 2.e para $250 \mathrm{~Hz}$ ). 0 centro da zona fundida das soldas TIG pulsado solidificaram predominantemente com ferrita de morfologia dendrítica (Fig. 2.f). 
Figura 2. Microscopia ótica das juntas soldadas.

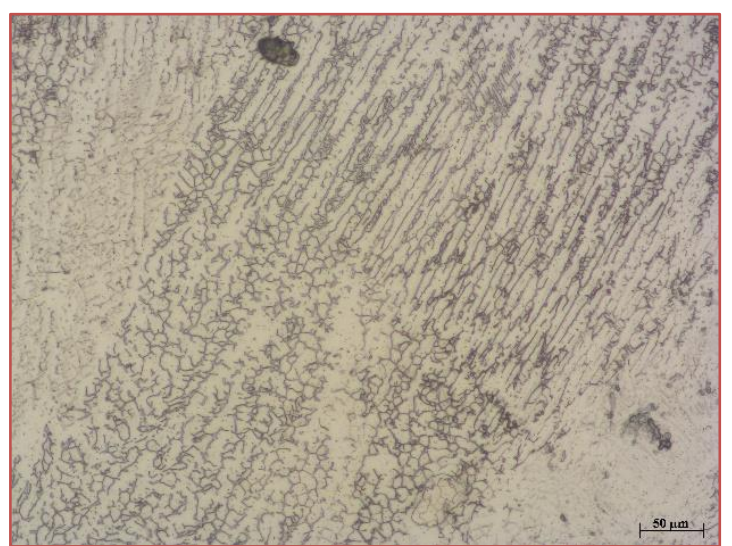

(a) TIG corrente constante: linha de fusão

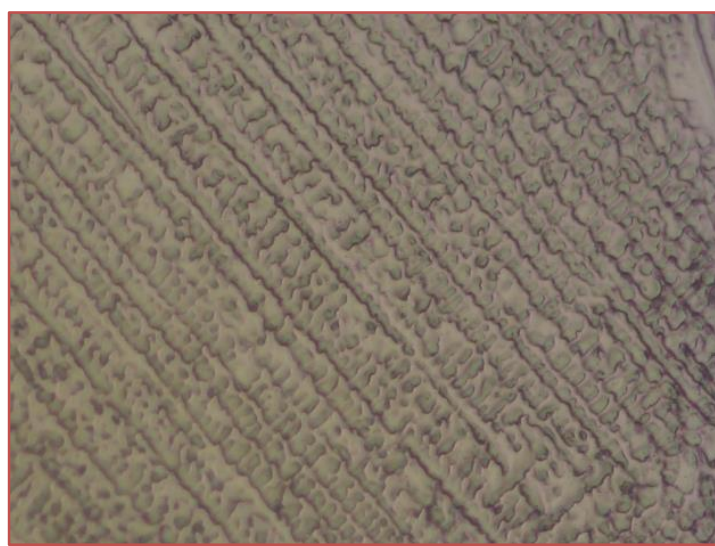

(c) TIG pulsado $1 \mathrm{~Hz}$ : linha de fusão

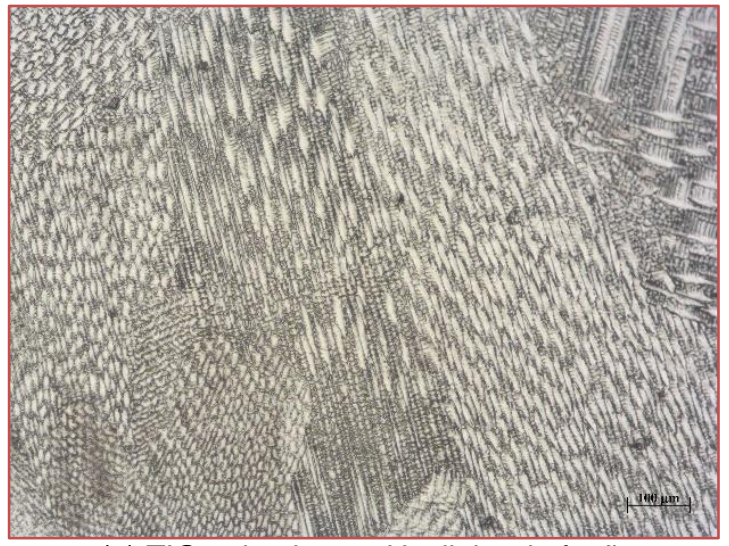

(e) TIG pulsado $250 \mathrm{~Hz}$ : linha de fusão

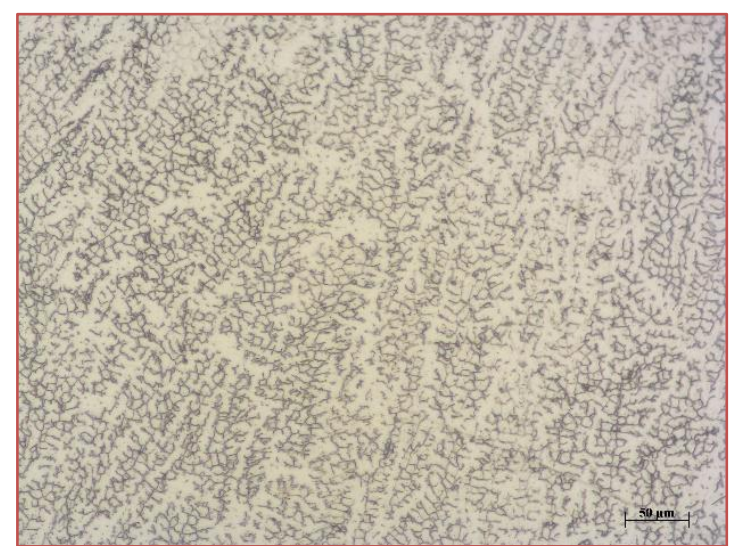

(b) TIG corrente constante: centro da solda

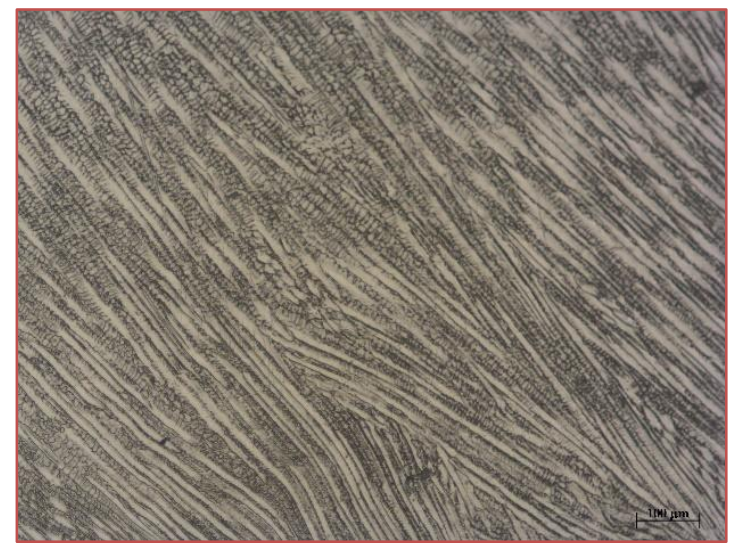

(d) TIG pulsado $40 \mathrm{~Hz}$ : linha de fusão

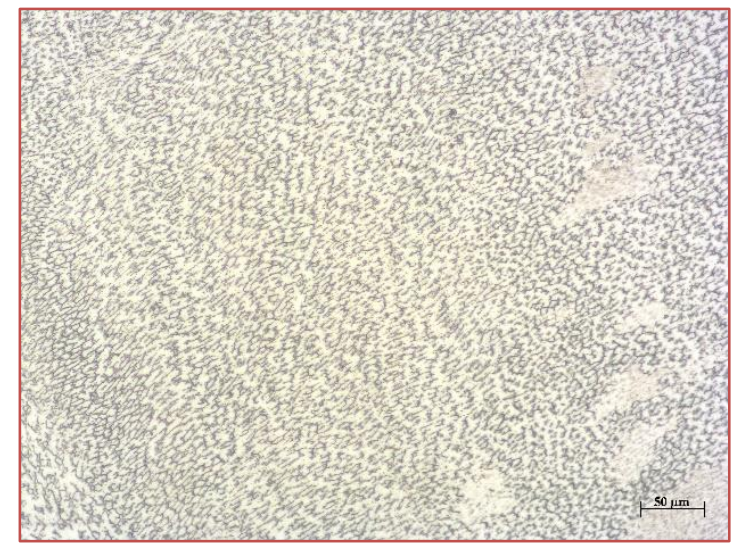

(c) TIG pulsado: centro da solda

A morfologia e composição química das fases $\gamma$ e $\delta$ foram investigadas com o uso do MEV no modo elétrons retroespalhados (BSE) e a microanálise química por EDS, conforme mostra a Figura 3. 
Figura 3. Morfologia e composição química típica das fases austenita e ferrita- $\delta$.

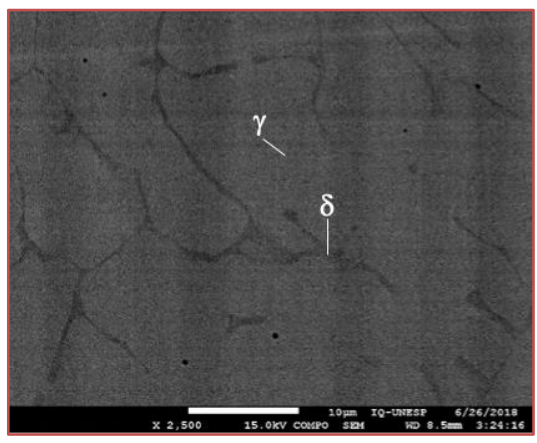

\begin{tabular}{|c|c|c|c|c|}
\hline \multicolumn{2}{|c}{$\mathrm{Cr}$} & $\mathrm{Mn}$ & $\mathrm{Fe}$ & $\mathrm{Ni}$ \\
\hline Fase $\alpha$ & 25.49 & 1.53 & 67.67 & 5.31 \\
\hline Fase $\gamma$ & 19.07 & 1.97 & 70.32 & 8.64 \\
\hline
\end{tabular}

A Figura 4 apresenta as curvas de polarização potenciodinâmica em $3.5 \% \mathrm{NaCl}$ das amostras soldadas, e a Figura 5 destaca o potencial de pite de cada amostra / microrregião na forma de um histograma. Sob o critério de potencial de pite, atribuiu-se a melhor performance nos testes de polarização potenciodinâmica em $3.5 \% \mathrm{NaCl}$ para a amostra soldada pelo processo TIG pulsado $1 \mathrm{~Hz}$. A literatura já esclareceu que a nucleção de pites tende a ocorrer preferencialmente na interface $\gamma / \alpha$ em uma junta soldada de aço inoxidável com microestrutura bifásica (3-4). Portanto, entende-se que a microestrutura da zona fundida obtida pelo procedimento de soldagem de menor velocidade de deslocamento resultou em uma interface $\gamma$ / $\alpha$ de maior espaçamento (relativamente aos outros procedimentos de soldagem) como consequência de uma solidificação de menor velocidade e uma poça de fusão calma (visto a menor frequência de bombardeamento de elétrons ao usar $1 \mathrm{~Hz}$ ). Um importante ponto a ser destacado é a elevada densidade de corrente observada durante o comportamento anódico passivo para essa EPS (10-5 e 10-4), pois isso pode implicar em degradação preferencial de fase (ferrita) previamente ao pite conforme já mencionado na literatura para juntas soldadas de aço inoxidável austeníticos (3). Os procedimentos de soldagem com frequência de $40 \mathrm{~Hz}$ e $250 \mathrm{~Hz}$ apresentaram desempenho relativamente iguais sob critério de potencial de pite para as microrregiões avaliadas. Contudo, o procedimento de soldagem TIG pulsado $250 \mathrm{~Hz}$ obteve uma performance para a linha de fusão que demonstrou menores densidades de corrente durante o comportamento anódico passivo, fator que é positivo e indica portanto maior nobreza desse procedimento do que o obtido pelo TIG pulsado $40 \mathrm{~Hz}$. 0 procedimento de soldagem TIG corrente constante apresentou o menor desempenho relativo, fator atribuído à história térmica da junta soldada. Esse procedimento caracteriza-se pelo maior aporte térmico, maior velocidade de soldagem e elevada taxa de resfriamento; condições que afetam a diluição, microsegregação e crescimento de fases.

Figura 4. Curvas de polarização potenciodinâmica em 3.5\% NaCl.
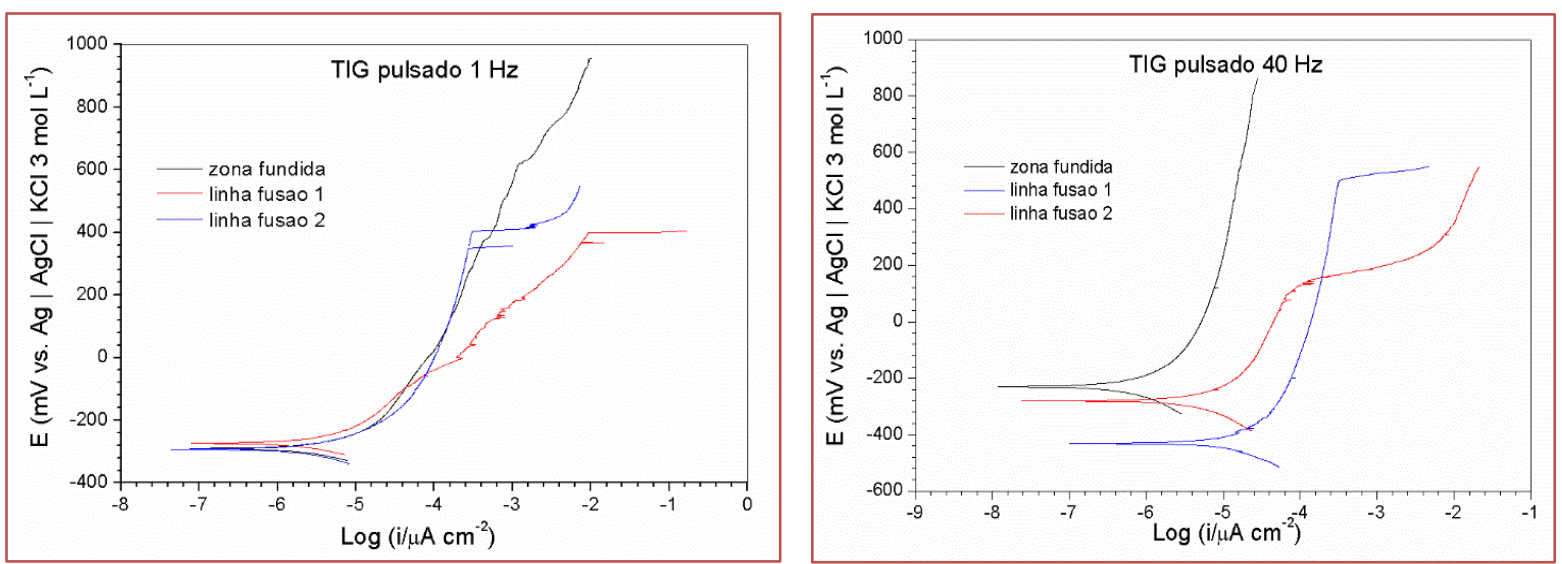

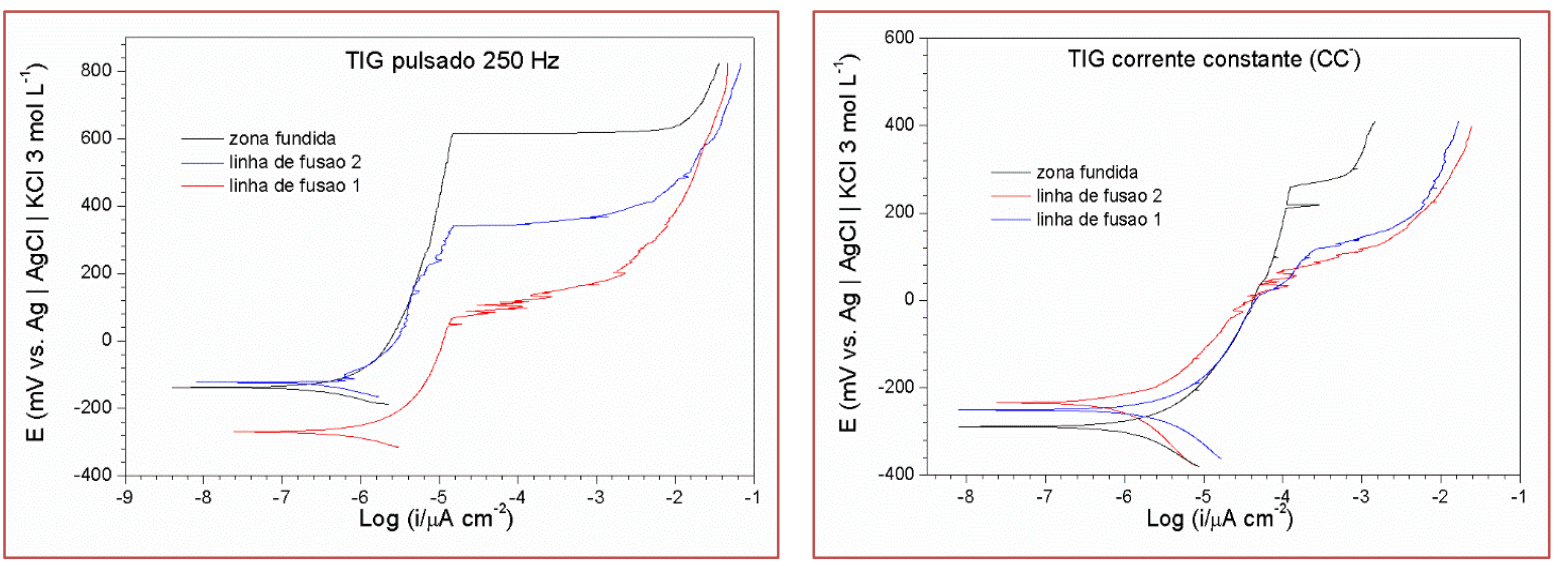

Figura 5. Histograma do potencial de pite (Epit).

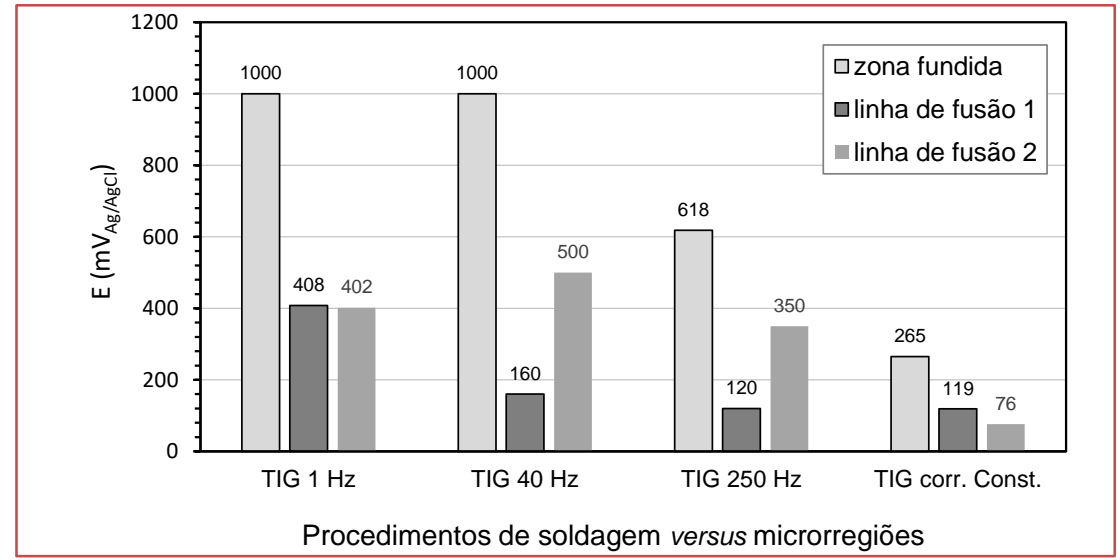

Os testes DL-EPR tiveram como objetivo mensurar o grau de sensitização (DOS - degree of sensitization) de cada microrregião (linha de fusão e zona fundida da solda) das juntas soldadas utilizando-se uma minicélula eletroquímica. Os resultados demonstraram que o procedimento de soldagem TIG pulsado 250 $\mathrm{Hz}$ obteve os mais nobres resultados para a linha de fusão (DOS=5.94\%) e zona fundida da solda (DOS=0.14\%), indicando menor ocorrência de microrregiões enriquecidas em Cr em função da história térmica causada pela soldagem. 0 procedimento de soldagem TIG pulsado $1 \mathrm{~Hz}$ obteve índices DOS pouco superiores quando comparado ao TIG pulsado $250 \mathrm{~Hz}$, contudo, deve-se destacar que o pico de dissolução da ferrita atingiu altíssimos valores $(120 \mathrm{~mA} / \mathrm{cm} 2)$ e, após esse pico, a microrregião manteve uma alta densidade de corrente, o que pode ser associado a um processo seletivo de corrosão durante o comportamento anódico passivo. Os procedimentos de soldagem TIG corrente constante e TIG pulsado 40 $\mathrm{Hz}$ apresentaram desempenho semelhante com pico de dissolução da ferrita na faixa de 40-50 mA/cm2 e DOS da microrregião linha de fusão em elevados índices na faixa de 18-26\%. O histograma dos índices DOS e as curvas dos testes DL-EPR são apresentados nas Figuras 6 e 7, respectivamente.

Observou-se a área exposta à varredura por microscopia ótica após cada teste DL-EPR e, de modo geral, a fase ferrita foi preferencialmente atacada, como mostra a Figura 8. 0 pico de dissolução da ferrita causou sua corrosão preferencial revelando a morfologia da fase. Na Figura 8.a é mostrado parcialmente a área molhada (área exposta à varredura) de um teste realizado na microrregião linha de fusão, onde observouse a ferrita acicular na extremidade esquerda da figura e, ao observar o centro da área molhada, nota-se a ferrita na forma de dendrita (Fig. 8.d). 
Figura 6. Histograma do grau de sensitização (DOS).

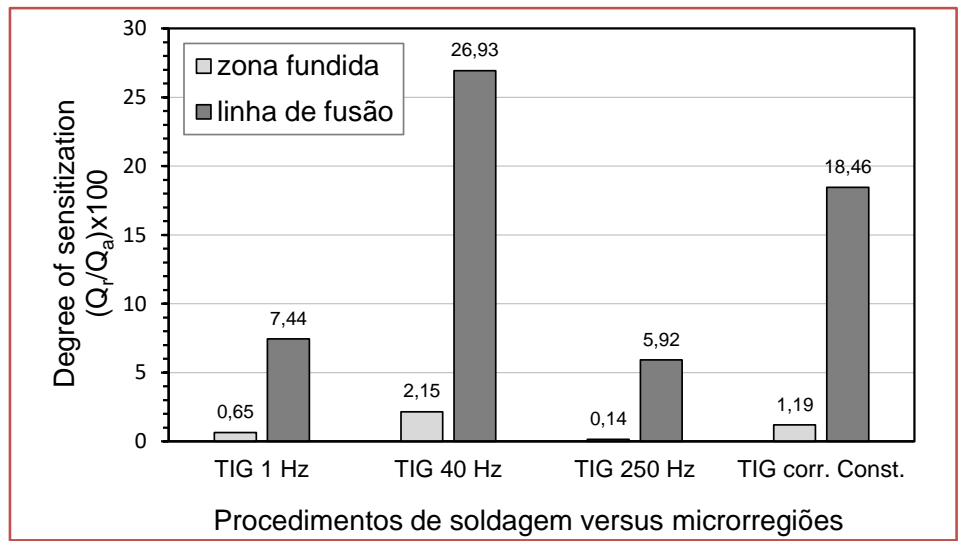

Figura 7. Curvas DL-EPR obtidas na solução 0.5 M H2SO4 + 0.01 M KSCN.
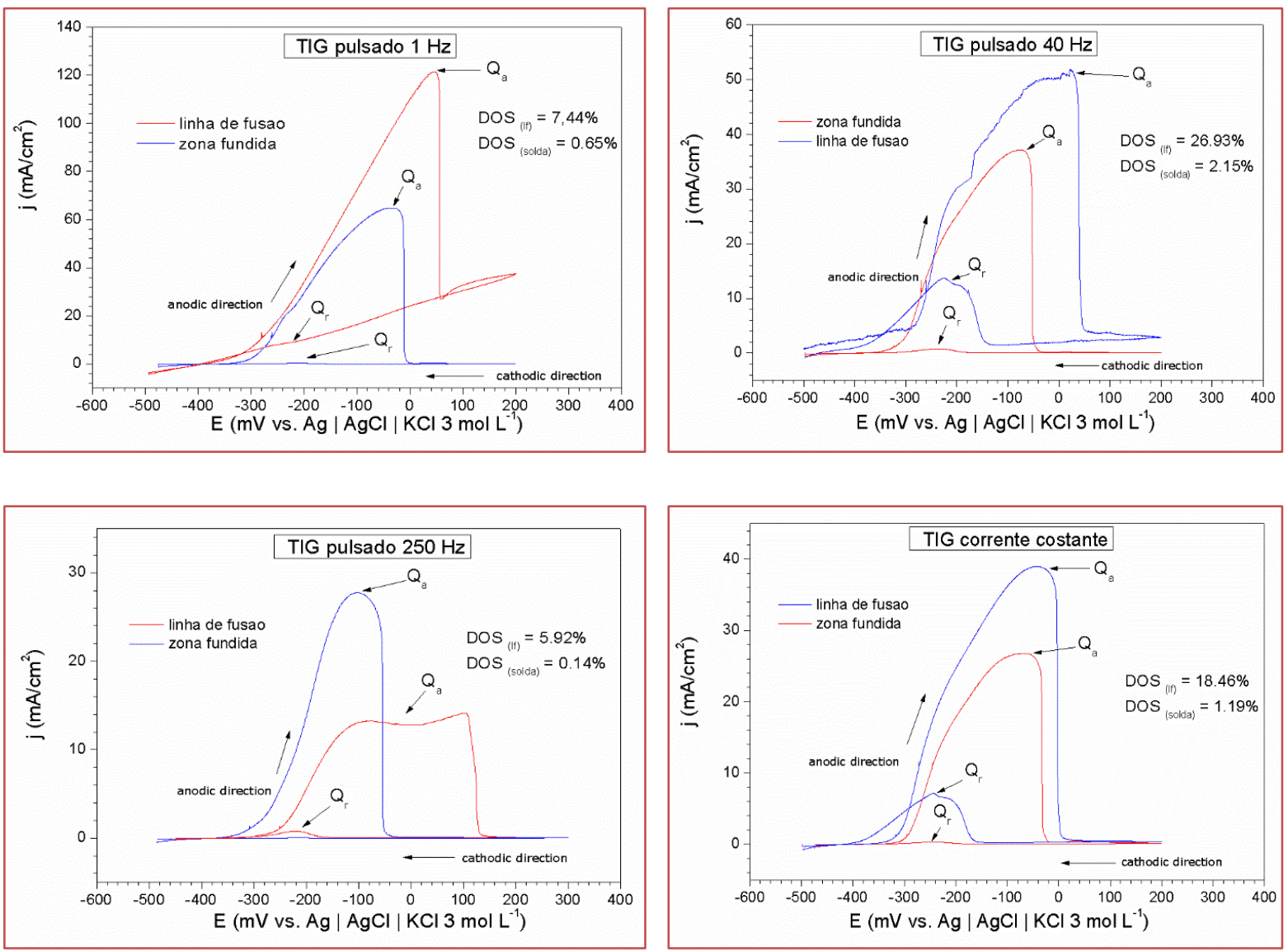
Figura 8. Micrografia obtida após testes DL-EPR em 0.5 M H2SO4 + 0.01 M KSCN observando em (a) área exposta à verredura da linha de fusão, (b) fronteira do microcapilar, (c) microrregião da interface metal de base / zona fundida onde os grãos apresentaram crescimento celular, (d) microrregião onde observou-se crescimento dendrítico da fase ferrita- $\delta$.

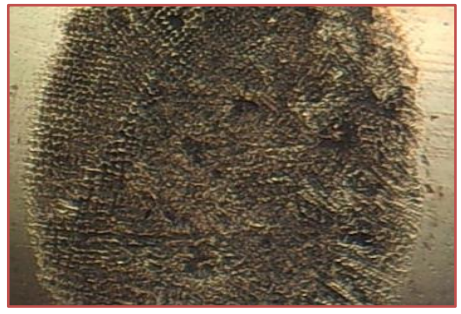

(a)

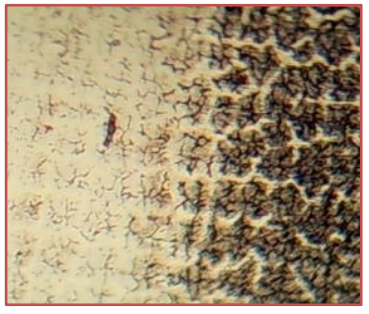

(b)

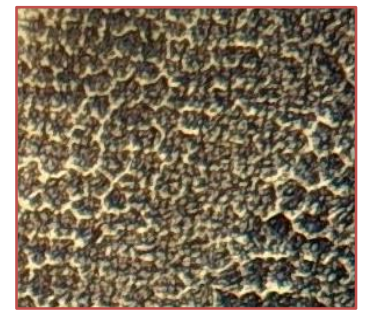

(c)

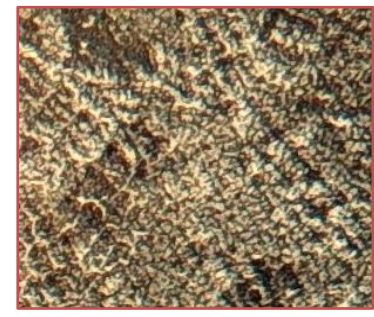

(d)

\section{CONCLUSÕES}

Com base nos resutados pode-se concluir que:

- A soldagem TIG pulsado com frequência de pulsação de $250 \mathrm{~Hz}$ resultou em uma junta soldada com melhor comportamento eletroquímico diante dos resultados obtidos nos ensaios de polarização potenciodinâmica em solução de $3.5 \% \mathrm{NaCl}$ e no ensaios de reativação potenciocinética de duplo ciclo (DL-EPR) na solução de 0.5M H2SO4 + 0.01M KSCN.

- $\quad 0$ procedimento de soldagem TIG pulsado $1 \mathrm{~Hz}$ obteve satisfatórios parâmetros eletroquímicos como Epit e DOS. No entanto, em ambos os testes observou-se que a linha de fusão resultou em elevadas densidade de corrente durante o comportamento anódico passivo, fator que comprometeu a qualidade de seus resultados. A hipótese tem como base a menor velocidade de soldagem obtida pela frequência de pulsação de $1 \mathrm{~Hz}(\sim 65 \mathrm{~mm} / \mathrm{min})$, afetando negativamente as linhas isotermas e consequentemente a metalúrgia da junta soldada.

- A escolha da frequência de pulsação para um procedimento de soldagem TIG pulsado deve considerar a velocidade de soldagem, evitando um lento deslocamento para que se obtenha uma linha de fusão / ZTA de maior resistência à corrosão.

- A soldagem TIG corrente constante se refere ao processo mais comumente empregado pela indústria e, segundo os resultados aqui apresentados, há disponível no mercado nacional equipamentos de soldagem que permitem otimizar a qualidade das soldas que são empregadas em meio asséptico ou corrosivo.

\section{AGRADECIMENTOS}

Os autores gostariam de agredecer a Fundação de Amparo à Pesquisa do Estado de São Paulo (FAPESP) pelo auxilio à pesquisa processo $\mathrm{n}$ ‥ 2016/08439-0 e a bolsa de treinamento técnico processo $\mathrm{n}$ ㅇ. 2018/02514-5, e também a empresa Soudap Engenharia pelo fornecimento das amostras soldadas.

\section{REFERÊNCIAS}

[1] TELLES, P.C.S.T. Vasos de pressão. 2nded. Rio de Janeiro: LTC, 2005.

[2] TELLES, P.C.S.T. Tubulações industriais: materiais, projeto e desenho. 10nded. Rio de Janeiro: LTC, 2012.

[3] GUILHERME, L.H. Influência da fase sigma na corrosão em microrregiões de juntas soldadas por processos MIG do aço inoxidável AISI 316L. 2017. 198p. Tese (Doutorado em Engenharia de Materiais) - Escola de Engenharia de São Carlos - Universidade de São Paulo, EESC/USP, São Carlos.

[4] MAGNABOSCO, R. Influência da microestrutura no comportamento eletroquímico do aço inoxidável UNS S31803 (SAF 2205). 2001. 181 p. Tese (Doutorado) - Escola Politécnica (POLI), Departamento de Engenharia Metalúrgica e de Materiais, Universidade de São Paulo (USP).

[5] WAINER, E.; BRANDI, S.D.; MELLO, F.D.H. Soldagem: processos e metalurgia. São Paulo: Edgar Blüncher, 
[6] LIPPOLD, J.C.; KOTECKI, D.J. Welding metallurgy and weldability of stainless steels. Nova Jersey: John Wiley, 2005.

[7] THE AMERICAN SOCIETY OF MECHANICAL ENGINEERS. ASME Seção IX: boiler and pressure vessel code welding and brazing qualifications - international code. New York, 2010a.

[8] GONÇALVES, H. M. Estudo do comportamento eletroquímico localizado nas diferentes regiões da liga AA2024-T3/AA7475-T651 soldada por FSW. 2018. 131p. Tese (doutorado em Química) - Instituto de Química de Araraquara - Universidade Estadual Paulista, IQ/UNESP, Araraquara.

[9] UNIVERSIDADE DE SÃO PAULO (USP), SÃO CARLOS-SP, Luis Henrique Guilherme et. al. Microcélula eletroquímica para ensaios de corrosão e sistema de medição de corrosão em microrregiões. INPI no. BR-10-2014012647-3. Maio 2014. 


\section{Capítulo 3}

\section{Avaliação dos fatores e das propriedades limitantes do polietileno de fonte renovável}

\section{Douglas Dias de Oliveira \\ Giovanna Amábile Duarte Rosa \\ Luiz Henrique Cavalcante Damacena \\ Anderson Maia \\ Rondes Ferreira da Silva Torin}

Resumo: 0 polietileno (PE) de fonte renovável é um bioplástico obtido a partir da canade- açúcar em escala industrial. Produtos feitos com PE renovável vem ganhando espaço no mercado, com isso estudos sobre a influência da reprocessabilidade em suas propriedades se tornam muito importantes. Nosso foco foi avaliar fatores limitantes de processabilidade do polietileno de alta densidade (PEAD) renovável sem aditivação de oxidantes, verificando a aplicação no âmbito performance técnica, estética e potencialidade de reuso. Amostras de PEAD foram submetidas a reprocessamentos em extrusora monorosca e analisadas por colorimetria, ensaios mecânicos, térmicos e reológicos. A partir do oitavo reprocessamento as amostras apresentaram alteração, amarelecimento, atribuído a inicio de processo degradativo, sem afetar de modo expressivo suas propriedades mecânicas. Amostras do décimo sexto reprocessamento mostraram maior índice de amarelecimento e degradação efetiva, com alterações nas propriedades mecânicas: aumento do alongamento do material e diminuição das resistências à tração e ao impacto.

Palavras Chave: PEAD, bioplástico, reprocessabilidade, degradação, reuso. 


\section{INTRODUÇÃO}

O uso de materiais poliméricos apresentou crescimento significativo nas últimas décadas, podendo-se observar na quantidade de utilitários plásticos que nos cerca no dia-a-dia e pesquisas demostram que o mercado mundial de termoplástico vem ultrapassando a margem de 180 milhões de ton/ano, atribuindo destaque ao Polietileno (PE), devido ao seu expressivo uso na confecção de embalagens descartáveis [1]

Para atender tal demanda o uso do petróleo se tornou limitante, já que existe o custo elevado e uma atenção maior para a sustentabilidade. Isto posto, tornou-se crucial o desenvolvimento de novos materiais plásticos provenientes de fontes renováveis, chamados de biopolímeros, tais como os polilácticos, amidos termoplásticos e o polietileno. Este último por sua vez é conhecido como polietileno verde, nome atribuído pela empresa Braskem, responsável pelo processo de obtenção em escala industrial do PE a partir da cana-de-açúcar.[9] É notório citar o PE verde, pela representatividade pertinente que possui no mercado e fácil acessibilidade que o consumidor possui em obtê-lo. Entretanto, ainda é importante ressaltar a preservação do meio ambiente, pois resíduos plásticos são os grandes vilões de problemas ambientais, pelo tempo que leva para suceder a degradação espontânea.

A reciclagem é a solução mais viável para o tratamento de resíduos plásticos e existe uma grande gama de estudos tecnológicos voltados para esta temática, em razão de alguns materiais perderem propriedades quando reprocessados, comprometendo assim a aplicação destinada ao mesmo. Por tais motivos o presente trabalho tem por objetivo avaliar o comportamento do PE verde quando reprocessados diversas vezes.

O PE utilizado para a realização deste trabalho é proveniente da cana-de- açúcar, produzido pela empresa Braskem, não é um material biodegradável e possui a mesmas características química, física e térmica do PE convencional, obtido do petróleo, assim não havendo restrição na sua aplicação. [1]

\section{MATERIAIS E MÉTODOS}

Para o desenvolvimento deste trabalho foi utilizado o PEAD verde fornecido pela Braskem, grade SGM9450F. Os reprocessamentos do PEAD verde foram realizados em em Extrusora Monorosca NZ, faixa de temperatura de 190 a $220{ }^{\circ}$ C. Após cada reprocessamento foram separadas amostras para caracterização a partir dos ensaios de tração, impacto, colorimétrico, calorimetria diferencial de varredura (DSC) e reológicos, como descritos a seguir.

\subsection{ENSAIOS DE TRAÇÃO}

Para o ensaio de tração foi utilizada a norma ASTM D638, e os corpos de provas foram confeccionados seguindo o padrão, totalizando cinco amostras, em temperatura ambiente, sob taxa de tensão de 50 $\mathrm{mm} / \mathrm{min}$. A máquina universal utilizada foi fabricada pela empresa Kratos® modelo KE $2000 \mathrm{MP}$, o software para aquisição de dados foi o Tracomp - Windows.

\subsection{ENSAIO DE IMPACTO}

Os ensaios de impacto foram realizados embasados na norma ASTM D6110 - Charpy, pelo método A e os corpos de provas confeccionados de acordo com a mesma. Os ensaios das amostras de PEAD reprocessadas foram conduzidos à temperatura ambiente. Fez-se uso do equipamento Zwick Roell® HIT25/50P, o pêndulo foi dotado de uma energia nominal de 1J.

\subsection{ENSAIO COLORIMÉTRICO}

Realizado em um colorímetro Delta Color Colorium 2, empregou-se o PEAD virgem como padrão comparativo para análise das amostras que demonstraram mudança significativa na coloração. 


\subsection{CALORIMETRIA DIFERENCIAL DE VARREDURA (DSC)}

Os ensaios de calorimetria foram realizados utilizando um DSC modelo Q20 da TA Instruments Foram realizadas duas varreduras no intervalo de $35^{\circ} \mathrm{C}$ a $200^{\circ} \mathrm{C}$ à $20^{\circ} \mathrm{C} / \mathrm{min}$, a primeira varredura foi realizada para apagar a história térmica da amostra e a segunda, rampa de aquecimento, coletou-se os dados.

\subsection{ANÁLISE REOLÓGICA}

Para analisar as propriedades reológicas em regime linear foi utilizado um reômetro rotacional de placas paralelas AR 2000 da TA instrutments. 0 método de cisalhamento oscilatório de baixa amplitude (COPA), com os parâmetros de 3,5

$\%$ de deformação e frequência variando de $100 \mathrm{rad} / \mathrm{s}$ à $0,01 \mathrm{rad} / \mathrm{s}$, foi utilizado para identificação da região de viscoelasticidade linear do PEAD de fonte renovável. As variáveis analisadas em regime viscoelástico linear foram os módulos de armazenamento ( $\left.G^{\prime}\right)$ e de perda ( $\left.G^{\prime \prime}\right)$, bem como na viscosidade em função da taxa de cisalhamento.

\section{RESULTADOS E DISCUSSÔES}

\subsection{COLORIMETRIA}

A análise colorimétrica é utilizada para identificação de alterações na coloração de materiais poliméricos, sendo que nesta pesquisa serviu como ferramenta de base auxiliando na detecção da possível degradação pela diferença de tonalidade.

De acordo com os resultados colorimétricos referentes a amostra PEAD virgem em comparação com PEAD reprocessado, as mudanças significativas na coloração, evidenciada pelo grau de amarelecimento, ocorreram no 8o e 16음 reprocessamento, denominados PEAD8 e PEAD16, respectivamente. Os resultados colorimétricos mostram, Figura 1 e 2, que ambas amostras, PEAD8 e PEAD16, apresentaram uma cor amarelo-avermelhado, em diferentes graus de amarelecimento. Na amostra PEAD8 este grau apresentou Db* de 3,71, sendo menor que na amostra PEAD16, a qual possui Db* de 4,77. Estes resultados indicam que houve degradação a partir do

$8^{\text {o }}$ reprocessamento, relativo à amostra PEAD8, que foi mais pronunciada no $16^{0}$ processamento. Variações desse tipo são características de degradação termooxidativa. [3]

Figura 1. Comparação grau de amarelecimento entre PEAD virgem e PEAD 8.

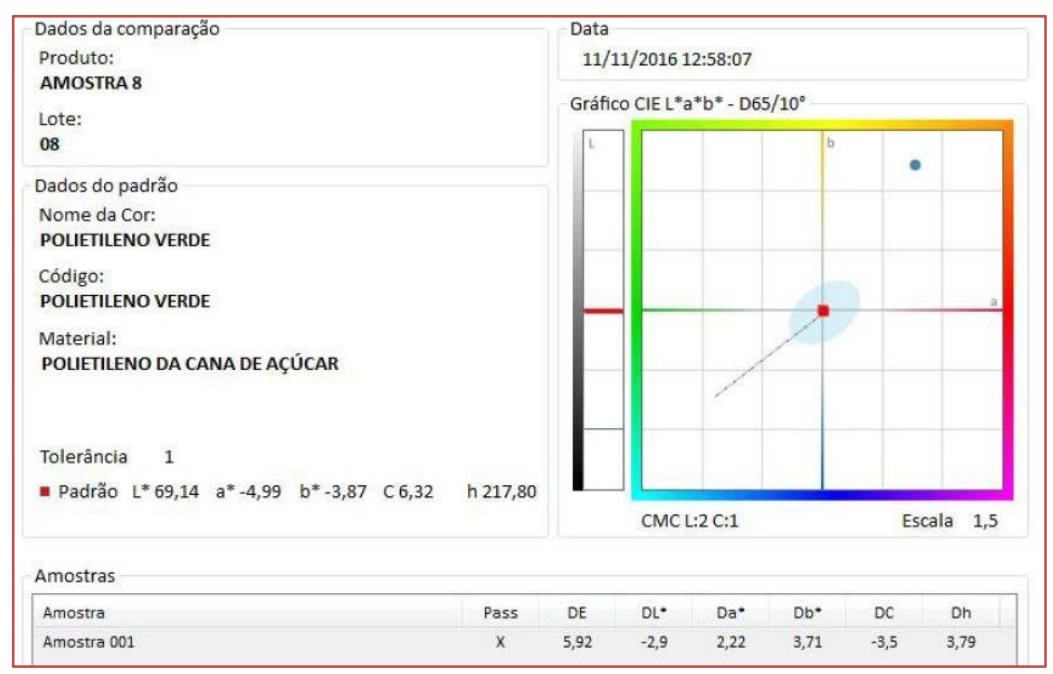


Figura 2. Comparação grau de amarelecimento entre PEAD virgem e PEAD 8.

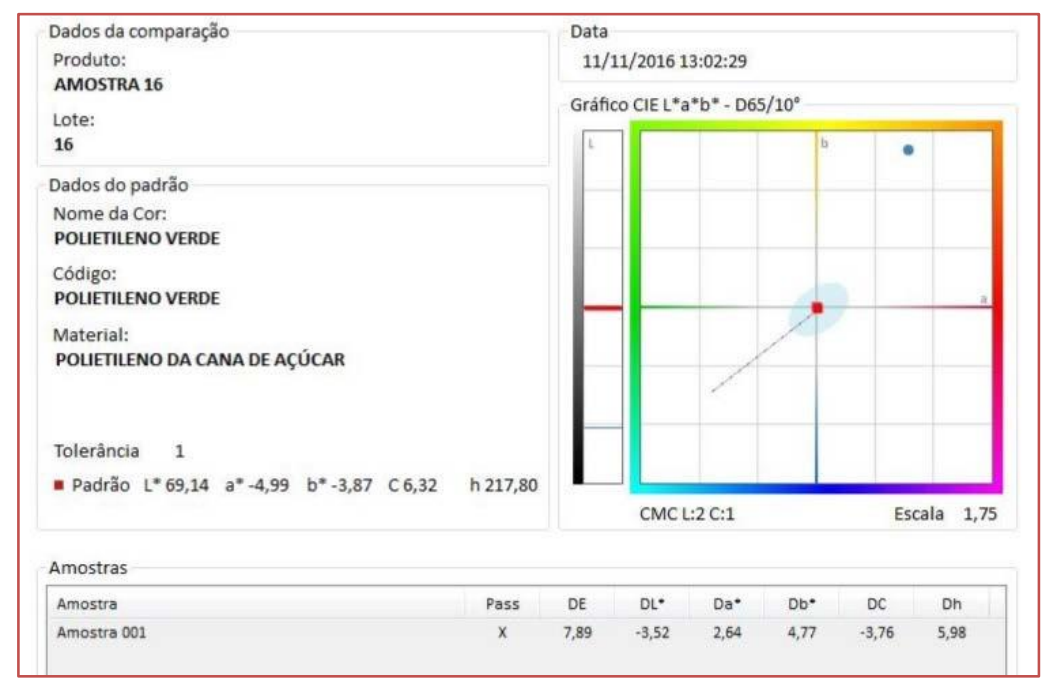

\subsection{ENSAIOS MECÂNICOS}

Os ensaios mecânicos são importantes para determinação de mudanças no comportamento físico estrutural do material analisado. Desta forma, ensaios mecânicos, de tração e impacto, foram utilizados para acompanhamento de mudanças na base do material relacionadas com o grau de reprocessabilidade do PEAD verde.

Os dados obtidos do Ensaio de Tração para as amostras do PEAD virgem, PEAD 8o e PEAD 16o processamentos, denominadas PEAD8 e PEAD16, respectivamente, estão relacionados na Tabela 1. Todas as amostras foram analisadas seguindo a norma ASTM D638 utilizando cinco corpos de prova. Os dados mostrados na Tabela 1 são os valores médios encontrados. A amostra PEAD do 8o processamento mostra leve aumento no limite de resistência à tração, provavelmente por conta da orientação da estrutura molecular reticulada do material. Já as amostras de PEAD do 16으 reprocessamento mostram decréscimo das propriedades de resistência a tração, uma vez que força máxima do PE verde virgem foi de 949,89N e para o PEAD16 foi de 894,38N, e o limite de resistência à tração reduziu de 23,38 MPa para 22,01 MPa, do PEAD virgem em comparação com PEAD16. Estes resultados propõem que houve processo de degradação térmica resultante de cisão intermolecular nas cadeias do polímero PEAD.

Por outro lado, o alongamento à ruptura foi maior na amostra do 16으 reprocessamento, pois é uma característica atribuída a degradação pelo processamento. Este resultado está em concordância com a literatura, visto que pesquisas feita por Alcântara et.al. [2] descrevem o polietileno com característica degradativa de aumento do peso molecular devido a cisão das cadeias e a formação de reticulações que provocam o maior estiramento do material. [1]

Tabela 1: Dados de Ensaio de Tração das amostras PEAD, PEAD 8o e PEAD 16oㅜ reprocessamento.

\begin{tabular}{|c|c|c|c|c|}
\hline Amostras & Força máxima (N) & $\begin{array}{l}\text { Limite de resistência } \\
\text { (Mpa) }\end{array}$ & Alongamento (\%) & $\begin{array}{l}\text { Alongamento linear } \\
(\mathrm{mm})\end{array}$ \\
\hline PEAD & 949,89 & 23,38 & 14,28 & 16,42 \\
\hline PEAD8 & 971,66 & 23,92 & 15,57 & 17,90 \\
\hline PEAD16 & 894,38 & 22,01 & 32,45 & 37,32 \\
\hline
\end{tabular}

Os resultados adquiridos no ensaio de impacto para as amostras de PEAD virgem, PEAD8 e PEAD16, sumarizados na Tabela 2, apontam variações mínimas, ou seja, não houve grandes perdas nas propriedades de impacto das amostras de PEAD mesmo após 16 reprocessamentos. Tais resultados podem dar a infundada impressão de que mesmo após 16 reprocessamentos o PEAD não sofreu degradação, porém esta característica é comum do polietileno, em razão de ser um polímero semicristalino, onde a dissipação de energia entre as moléculas é mais fácil e com isso a perda de propriedades físicas macroscópicas são menores. A tendência é que com o aumento dos reprocessamentos 
por extrusão as variações nas propriedades mecânicas sejam mais notáveis. Uma vez que o aumento de reprocessamentos impacta diretamente na formação de reticulações, re- enovelamento causando redução na mobilidade das moléculas e consequentemente, dificultando a dissipação de energia favorecendo, portanto, o processo degradativo por cisão radicalar das cadeias poliméricas. [2]

Tabela 2: Dados de Ensaio de Impacto das amostras PEAD, PEAD 8o e PEAD 16o reprocessamento.

\begin{tabular}{|c|c|c|}
\hline Amostras & Energia de Impacto (J) & Resultado $(\mathrm{J} / \mathrm{m})$ \\
\hline PEAD & 0,8678 & 260,3 \\
\hline PEAD8 & 0,88 & 269,9 \\
\hline PEAD16 & 0,836 & 256,4 \\
\hline
\end{tabular}

\subsection{ANÁLISE DE DSC}

Análises de Calorimetria Diferencial de Varredura (DSC) foram conduzidas com o objetivo de investigar o comportamento térmico, a partir do monitoramento das temperaturas de fusão (Tm) e cristalização (Tc), em função do grau de reprocessamento do PEAD.

Foram realizadas curvas de DSC das amostras de PEAD virgem como padrão comparativo para as amostras PEAD 8 e PEAD16, figuras 3, 4 e 5, respectivamente. As curvas de DSC não demostram variações significantes no evento endotérmico Tm, as mudanças não foram significativas para alterara temperatura de fusão. [5]

Figura 3. Curva de DSC do PEAD virgem.

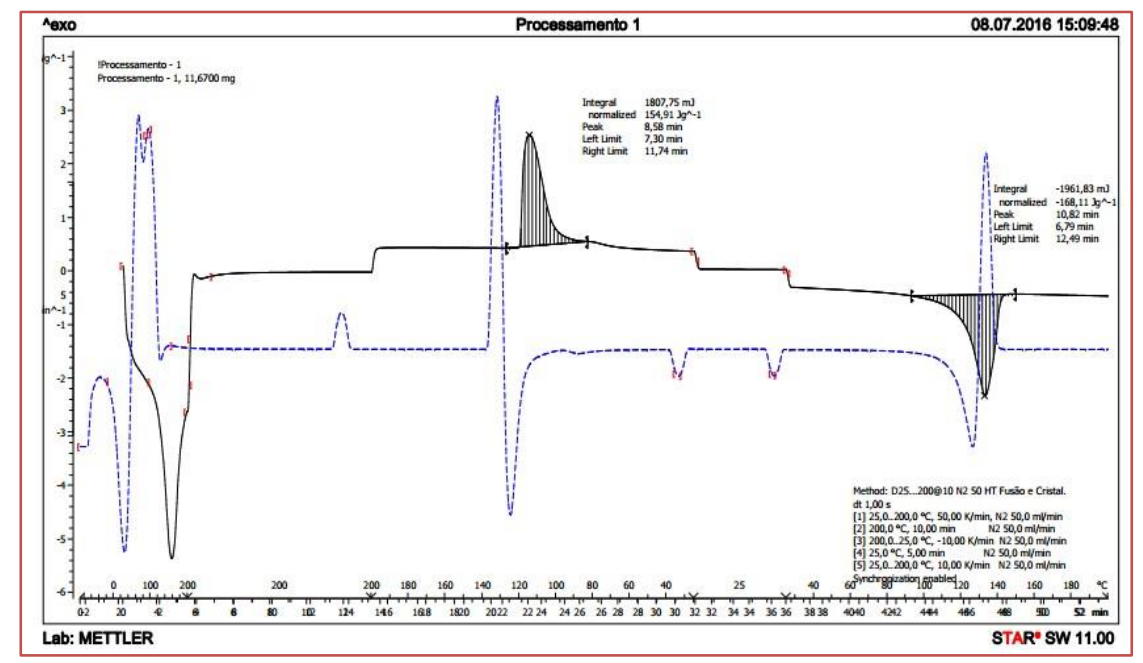


Figura 4. Curva de DSC do PEAD8.

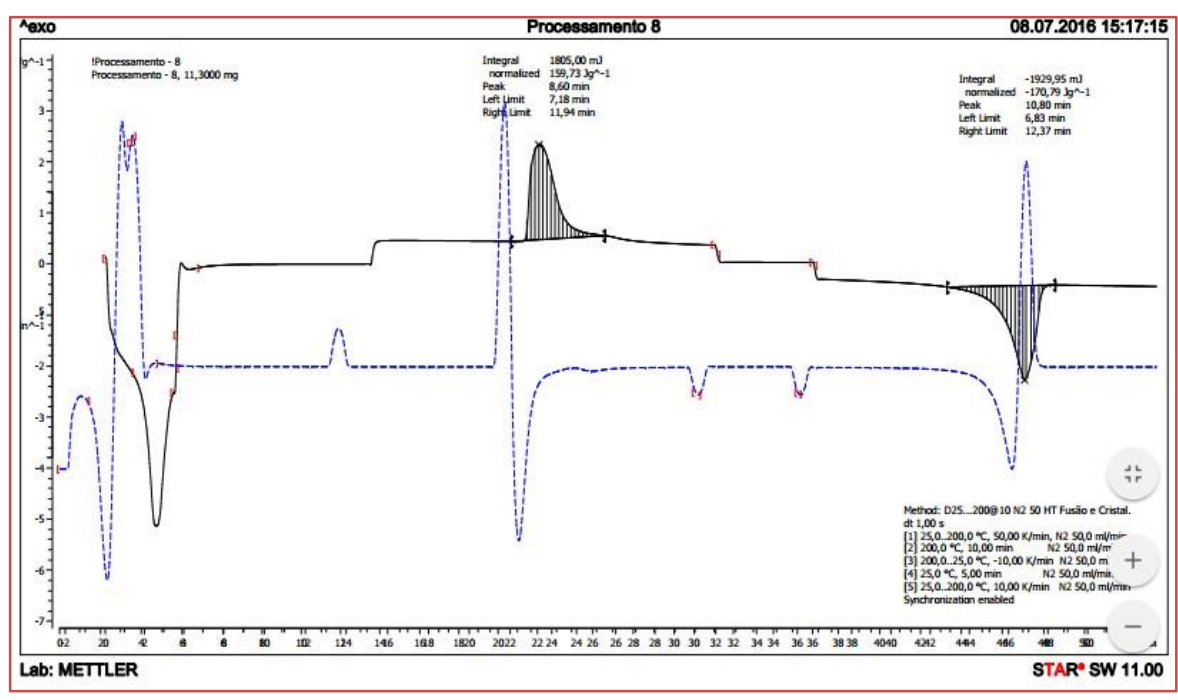

Figura 5. Curva de DSC do PEAD16.

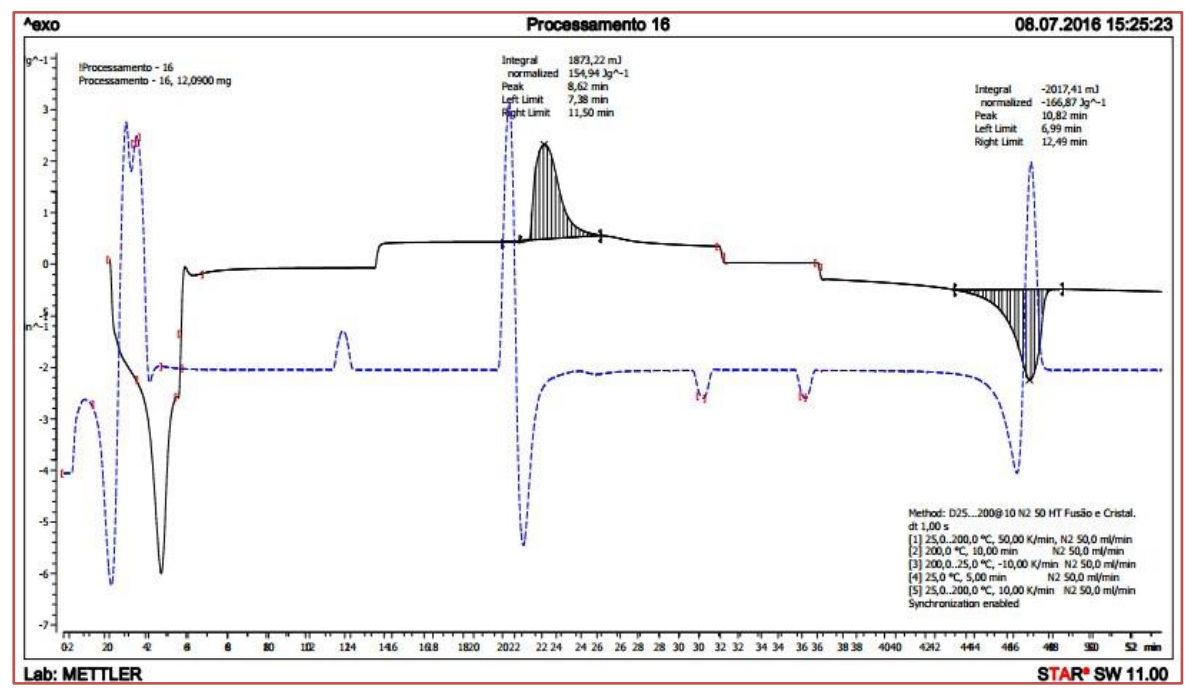

Os valores percentuais do grau de cristalinidade, evidenciados na Tabela 3, oriundos a partir das curvas de DSC, figuras 3, 4 e 5, mostram um leve aumento da cristalinidade na amostra PEAD8 com relação ao PEAD virgem, podendo ser justificado ao associá-lo à conformidade das cadeias por consequência do processamento, todavia na amostra PEAD16 fica notável o efeito degradativo pelo declínio da cristalinidade, comprovando que a amostra possui reticulações.[5][6]

Tabela 3: Percentual do Grau de Cristalinidade.

\begin{tabular}{|c|c|}
\hline Amostras & Grau de Cristalinidade \\
\hline PE & $57,97 \%$ \\
\hline PEAD8 & $58,89 \%$ \\
\hline PEAD16 & $57,54 \%$ \\
\hline
\end{tabular}

\subsection{ENSAIOS REOLÓGICOS}

As análises reológicas em regime oscilatório relacionam as propriedades viscoelásticas lineares dos materiais poliméricos e contribuem para identificar alterações na estrutura molecular de polímeros no estado fundido. A Figura 6 mostra os módulos de armazenamento ( $\left.G^{\prime}\right)$ e módulo de perda ( $\left.G^{\prime \prime}\right)$ em função 
da frequência angular das amostras de PEAD virgem e reprocessados PEAD8 e PEAD16. As curvas dos módulos G' e G", figura 6, mostram de maneira geral um aumento em função da frequência aplicada e variações no platô elastomérico, as quais estão relacionadas com a distribuição do peso molecular, resultante da cisão da cadeia molecular e reticulações das cadeias laterais, promovendo aumento do volume da cadeia polimérica, transmutando assim os módulos de armazenamento e perda.[4] [10]

Figura 6. Gráficos G' e G” em função do ângulo de frequência.

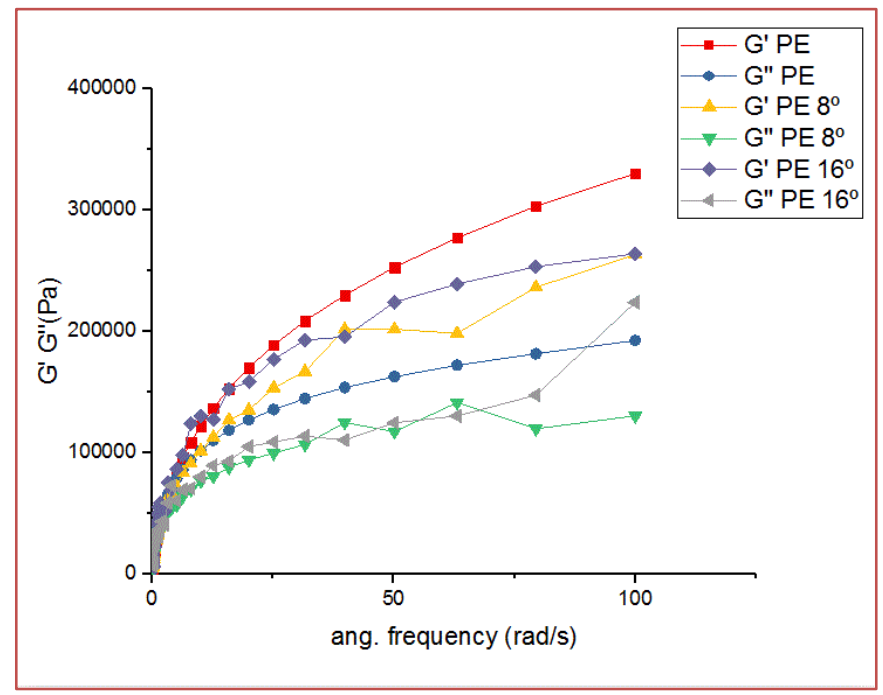

A Figura 7 mostra curvas de viscosidade em função da taxa de cisalhamento. Ao compará-las fica evidenciado que há variação na viscosidade relacionada à diminuição da massa molecular, associada ao processo degradativo da cadeia polimérica, que intervém no aumento de cristalinidade, devido à restrição da fase amorfa. [8]

Figura 7. Viscosidade em função tensão de cisalhamento das amostras PE, PE 8o e PE $10^{\circ}$

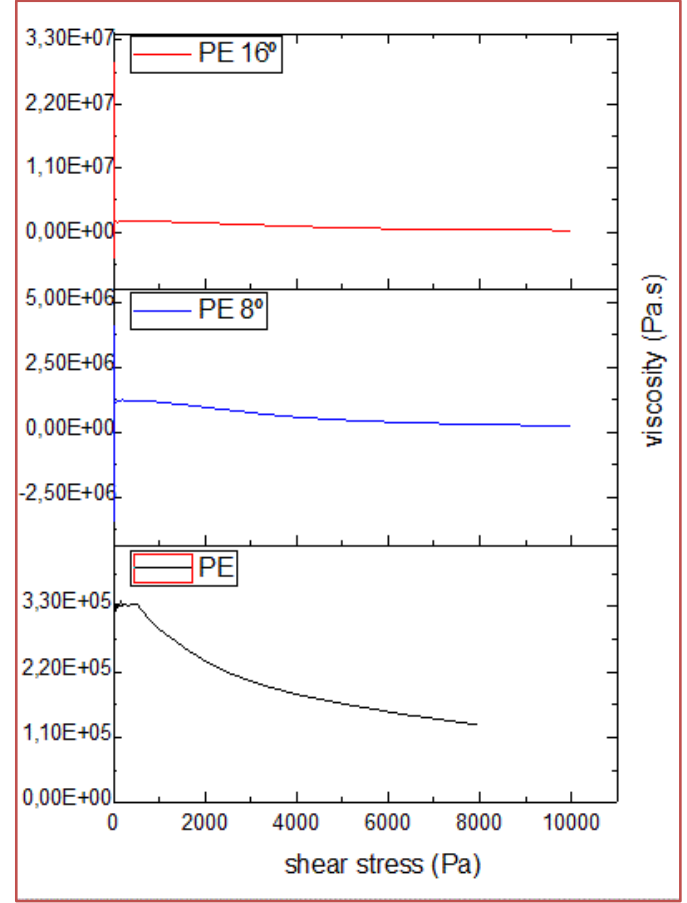




\section{CONCLUSÃO}

Ao submeter o polietileno verde em extrusora monorosca por dezesseis ciclos, modificações na coloração, identificadas pela presença de tons amarelados em sua superfície, demonstraram que para fins estéticos, este polímero tem aplicações restringidas no decorrer de sua recuperação em subsequentes processos. Não obstante, ao se investigar os ensaios mecânicos, verificou-se que o material em estudo evidencia oscilações ínfimas em suas propriedades de resistências a tração e impacto, e resultados adquiridos por meio das técnicas de DSC e reologia indicam diminuição da cristalinidade na estrutura somente na décima sexta amostra utilizada neste estudo, fator decorrente do progresso de degradação, certificando desta forma, que o polietileno procedente da cana de açúcar apresenta um perfil passível de reciclagem.

\section{REFERÊNCIAS}

[1] BELLOLI, Rodrigo. Polietileno Verde do etanol da cana-de-açúcar brasileira: Biopolímeros de classe mundial. Tese (Bacharel em Engenharia química), Universidade Federal do Rio Grande do Sul, Porto Alegre, 2010.

[2] ALCÂNTARA, R. L.; CARVAlHO, L. H.; RAMOS, S. M. L. S. Propriedades Mecânicas de Resíduos Plásticos Urbanos da Região Nordeste: Influência das Condições de Processamento. Revista: Polímeros, n.5, p.42, 1995.

[3] PAOLI, M. A. Degradação e estabilização de polímeros. 4. ed. São Paulo: Artlibler Editora. 2008.

[4] BRETAS, E. S. R.; d' Ávila, A. M. Reologia de Polimeros Fundidos. 2. Ed. São Carlos: EdUFSCar, 2010.

[5] LUCAS, F. E.; SOARES, G. B.; MONTEIRO, E. C. E. Caracterização de Polímeros: Determinação de Peso Molecular e Análise Térmica. 1. Ed. Rio de Janeiro: E-PAPERS, 2001.

[6] CANEVARolo, V. S. Jr.; Ciência dos Polímeros: Um tesxto básico para tecnólogos e engenheiros. 2. Ed. São Paulo: Artiliber. 2006.

[7] GUimarãES, O. C. M.; COUTINHO, M. B. F.; ROCHA, C. G. M.; BRETAS, E. S. Reologia de Polietileno de Alta Densidade Tenacificado com Polietileno Elastomérico. Polímeros: Ciência e Tecnologia, vol. 13, no 2, p. 135-140, 2003.

[8] BATALiOTTI, D, M.; Avaliação da degradação do polipropileno sob múltiplas extrusões com e sem antioxidante. Universidade Tecnológica Federal do Paraná, Londrina, 2016.

[9] ANDREW, W.; Handbook of Biopolymers and Biodegradable Plastics. 1. Ed. Waltham, USA: Sina Ebnesajjad. 2006.

[10] Kealy, T.; Rheological Analysis of the Degradation of HDPE During Consecutive Processing Steps and for Different Processing Conditions, Journal of Applied Polymer Science 112 (2): (2009) 639-648.

[11] Mittal, V.; Renewable Polymers: Synthesis, Processing and Technology, 1. Ed. Salem, Massachusetts. USA: Scrivener Publishing LLC, 2012. 


\section{Capítulo 4}

\section{Avaliação da refrigeração criogênica na usinagem chc do aço inoxidável martensítico AISI 440C}

\section{Fernando Prando Dacas}

Rodrigo Cardoso Costa

Elandir Antonio Desidério

Fernando Michelon Marques

Eduardo Augusto Flesch

Felipe Canal

Resumo: Materiais de difícil usinabilidade como o aço inoxidável AISI 440C apresenta grande desgaste na aresta de corte de insertos, o qual é potencializado pelo calor do atrito abrasivo. Neste estudo foi desenvolvido uma metodologia para verificar a eficiência do método de refrigeração de corte frente ao desgaste de flanco do inserto e integridade da superfície usinada. As análises mostraram que o método de refrigeração a seco apresentou menor rugosidade de superfície usinada para 15 minutos $(\mathrm{Ra}=1,449$ $\mu \mathrm{m})$. 0 método de refrigeração criogênico com nitrogênio líquido ofereceu menor desgaste de flanco para 15 minutos de usinagem ( $\mathrm{Vb}=0,168 \mathrm{~mm})$. Os testes de usinagem demostraram que o inserto TNMG160404 Classe 6525 suporta os parâmetros de usinagem, para e os métodos de refrigeração e o material adotado conforme norma ABNT NBR ISO 3685.

Palavras-Chave: Usinagem, Nitrogênio líquido, Desgaste, Rugosidade. 


\section{INTRODUÇÃO}

Materiais de difícil usinabilidade, como o aço inoxidável martensítico AISI 440C, apresentam maior desgaste na aresta de corte, o qual é potencializado pelo calor do atrito abrasivo durante operações de usinagem. Partículas desses materiais ficam aderidas na superfície do inserto em razão da elevada temperatura do corte (1).

Para auxiliar no prolongamento da vida útil da ferramenta deve-se aumentar a taxa de extração de calor da área de corte, mediante a utilização de fluidos refrigerantes ou lubri-refrigerantes.

A grande desvantagem dos fluidos de corte convencionais, no caso líquido emulsivo, é o descarte posterior ao uso. Esses fluidos são altamente contaminantes ao solo e água, sem contar os problemas de saúde ao operador. Com isso, vem se buscando alternativas mais efetivas para realizar a extração de calor, com menos impacto ao meio ambiente.

O nitrogênio líquido como fluido refrigerante de corte vem sendo utilizado, em razão da característica de ser inerte no meio ambiente e da baixíssima temperatura (2). A refrigeração de corte com nitrogênio líquido corrobora para a caracterização criogênica desse método de refrigeração. No estudo de Vicentin e Sanchez (2009), foi observado maior eficiência do inserto frente ao desgaste da aresta de corte na usinagem do material INCONEL 718® com refrigeração por nitrogênio líquido. Na Figura 1 pode ser observado a evolução do desgaste frente aos diferentes tipos de refrigeração estudados por Vicentin e Sanchez (2009).

Figura 1 - Desgaste da aresta de corte

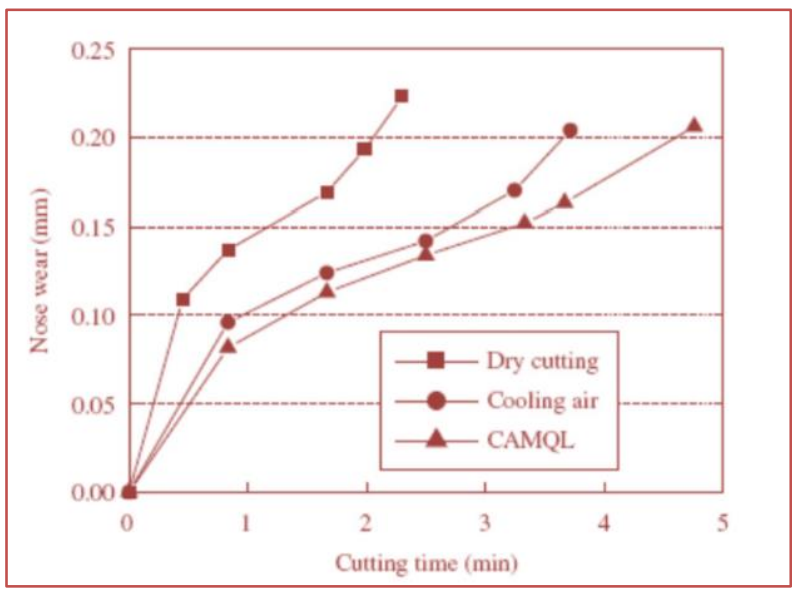

Fonte: (3).

Este trabalho tem por finalidade avaliar o desgaste de aresta de corte de um inserto de metal duro e rugosidade superficial do aço inoxidável martensítico AISI 440C, mediante a variação do método de refrigeração para os mesmos parâmetros de corte, na usinagem de torneamento externo em máquina CNC.

\section{METODOLOGIA}

Este estudo consiste em avaliar o desgaste da aresta de corte e a integridade superficial da peça de trabalho, conforme características operacionais de usinagem e do método de refrigeração de corte. A cada ciclo de 6 passes de usinagem, com tempo aproximado de 2 min, foi capturado uma imagem da aresta de corte do inserto e verificado a rugosidade superficial usinada.

A Tabela 1 apresenta os valores ajustados para cada parâmetro de corte, conforme indicação do fabricante do inserto código TMMG160404MQ e classe CA6525 (2). O inserto possui substrato em metal duro com camada de revestimento em TiCN+Al203+TiN aplicado por Chemical Vapour Deposition - CVD. 
Tabela 1-Parâmetros de corte

\begin{tabular}{|c|c|}
\multicolumn{1}{|c|}{ Parâmetro } & Valor Ajustado \\
\hline Velocidade de corte (Vc) & $150 \mathrm{~m} / \mathrm{min}$ \\
\hline Profundidade de corte (ap) & $0,4 \mathrm{~mm}$ \\
\hline Avanço de corte (f) & $0,15 \mathrm{~mm} / \mathrm{rev}$ \\
\hline \multicolumn{2}{|c|}{ Fonte - (4) }
\end{tabular}

A usinagem de torneamento externo foi realizada no torno CNC ROMI Centur 30D com o mesmo parâmetro de corte, para os diferentes métodos de refrigeração.

O material de estudo foi o aço inoxidável martensítico AISI 440C maciço de microestrutura recozida. Na Tabela 2 pode ser observado a composição do material de interesse. As dimensões nominais dos corpos de prova utilizados nos testes de usinagem podem ser analisadas na Tabela 3.

Tabela 2 Composição química do material AISI 440c (\% em peso)

\begin{tabular}{|c|c|c|c|c|c|c|c|}
\hline Elemento & $\mathrm{C}$ & $\mathrm{Si}$ & $\mathrm{Mn}$ & $\mathrm{P}$ & $\mathrm{S}$ & $\mathrm{Cr}$ & Mo \\
\hline Teórico (5) & $0,95-1,2$ & $\begin{array}{c}\text { Máx } \\
1,00\end{array}$ & Máx 1,00 & Máx 0,04 & Máx 0,03 & $16,0-18,0$ & Máx 0,75 \\
\hline Analisado & 0,99 & 0,61 & 0,43 & 0,031 & 0,028 & 16,42 & 0,06 \\
\hline
\end{tabular}

Tabela 3 - Dimensões do corpo de prova

\begin{tabular}{|c|c|}
\hline \multicolumn{2}{|c|}{ Dimensões } \\
\hline Diâmetro bruto & 44,10 \\
\hline Diâmetro final médio & 26,00 \\
\hline Comprimento usinado & 75,00 \\
\hline
\end{tabular}

Fonte: Próprio autor

No método de corte a seco não foi utilizado nenhum fluido refrigerante líquido ou gasoso. 0 fluido de corte líquido emulsivo foi aplicado pelo método de fluxo contínuo, sendo o jato direcionado na região do corte pela parte superior do inserto. 0 líquido emulsivo utilizado neste estudo foi composto por uma mistura de água e óleo solúvel semi-sintético Rocol Ultracut $370 \mathrm{AL} \circledast$, na proporção de 20 litros de água para 1 litro de óleo solúvel. Já o método de refrigeração criogênica foi aplicado por fluxo contínuo de nitrogênio líquido, a pressão de 1 bar, na região do corte pela parte inferior do inserto.

Para medir a rugosidade das superfícies usinadas foi utilizado um rugosímetro portátil modelo TR-220® do fabricante TIME. 0 equipamento foi configurado com os seguintes parâmetros: comprimento de análise de 12, $5 \mathrm{~mm}$; filtro GLAUSS; range de $\pm 40 \mu \mathrm{m}$; e parâmetro de rugosidade média Ra. Foram efetuadas 3 medições em regiões distintas de cada amostra. Os dados de rugosidade de cada ciclo foram inseridos em planilha de cálculo para observar de forma gráfica a evolução da rugosidade.

Para medir o desgaste do flanco do inserto foi aplicado método de macroscopia digital. Neste estudo foi utilizado um estereoscópio digital modelo 4083.B5 do fabricante OPTIKA. As imagens foram processadas no software OPTIKAVIEW7 com o aumento de 50X. Na Figura 2 pode ser observado a cota $\mathrm{Vb}$ a qual caracteriza o desgaste de flanco conforme norma NBRISO 3685 (6). 
Figura 2 - Desgaste do inserto após a usinagem

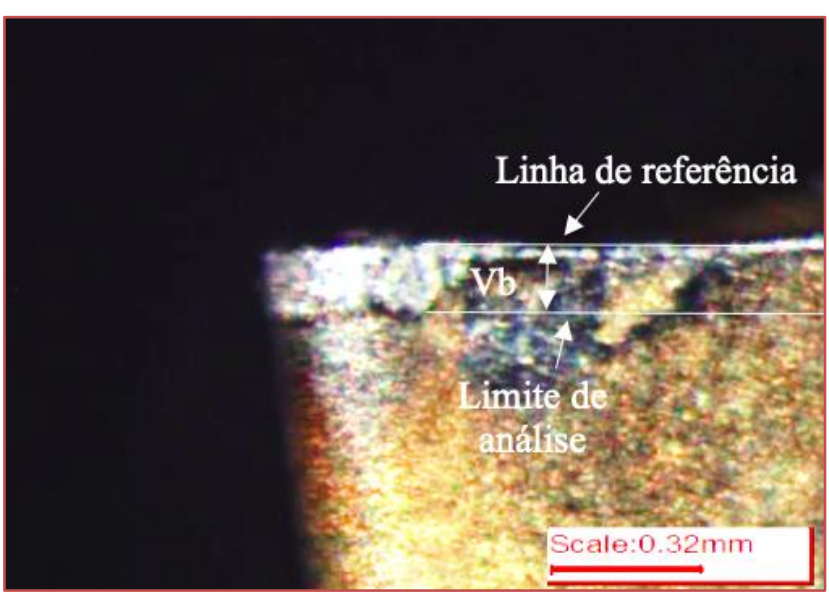

Fonte - Próprio autor

Os valores de desgaste de flanco foram inseridos em planilha de cálculo para observar de forma gráfica a evolução do desgaste abrasivo.

\section{RESULTADOS E DISCUSSÃO}

A medição do desgaste de flanco do inserto possibilitou identificar a influência do método de refrigeração de corte. Como pode ser observado na Figura 3, o desgaste de flanco do inserto tende a ocorre de forma crescente para todos os métodos de refrigeração de corte avaliados. Analisando a linha de tendência dos métodos de refrigeração de corte a seco e com líquido emulsivo fica evidente que a partir de 10 minutos de usinagem ocorre aumento mais acentuado do desgaste de flanco do inserto. Analisando o desgaste das arestas de corte no tempo de 15 minutos confirma-se uma tendência de melhor desempenho do método de refrigeração criogênico, por nitrogênio líquido, frente aos métodos avaliados.

Também é possível verificar no gráfico da Figura 3 que a usinagem com líquido emulsivo obteve um desgaste mais elevado com relação a usinagem seco, o que contradiz muitas literaturas (7) (8). Uma possível explicação para esse fenômeno é que os insertos são projetados para trabalhar sem refrigeração. A baixa eficiência das propriedades lubi-refrigerante do líquido emulsivo utilizado neste estudo, de certa forma, permitiu maior atrito da aresta de corte durante o processo de usinagem de torneamento externo (9)

Figura 3 - Desgaste do inserto em função do tempo

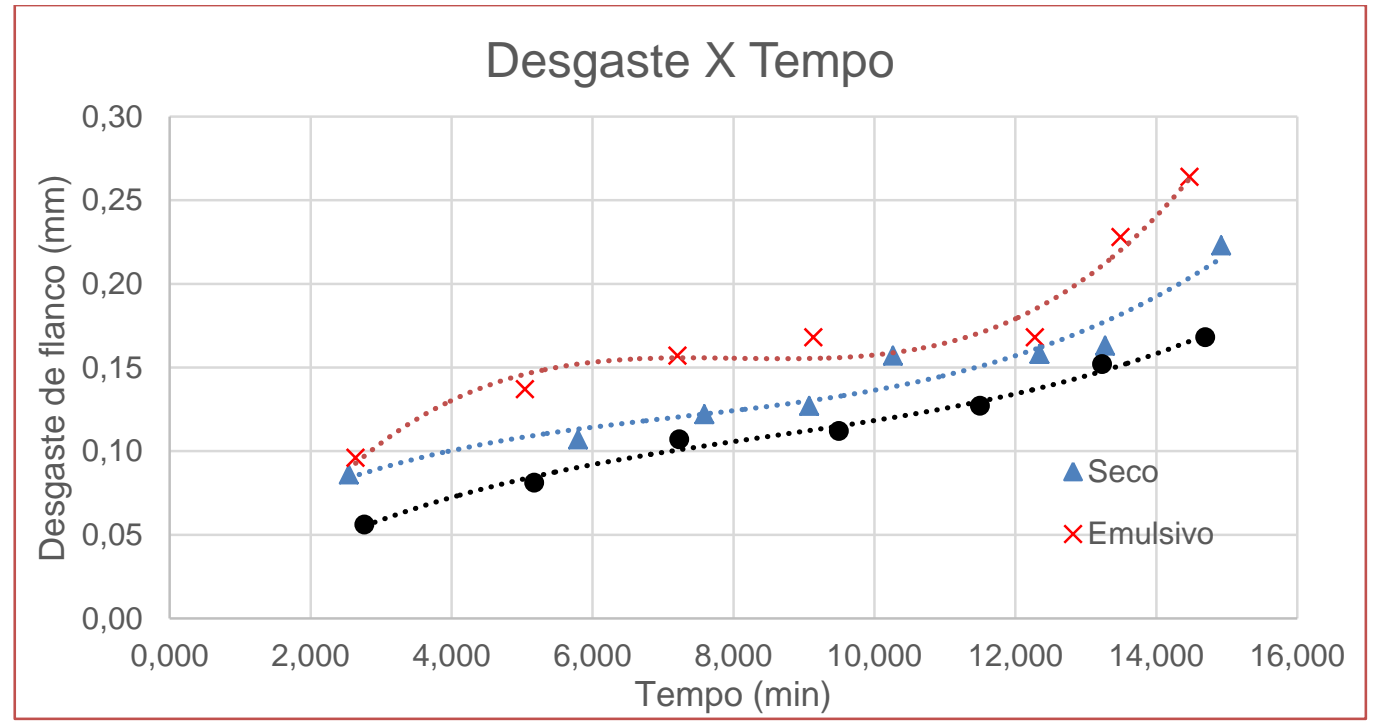




\section{Fonte - Próprio autor}

Por outro lado, os ensaios de usinagem realizados com a injeção de nitrogênio líquido, a uma temperatura extremamente baixa, evidenciaram redução do desgaste de flanco ( $\mathrm{Vb}$ ) do inserto. 0 método de refrigeração criogênica reduziu o desgaste da ferramenta a cerca de $25 \%$ em relação a usinagem a usinagem a seco e 36\% em comparação com a usinagem com líquido emulsivo, para o tempo de 15 minutos. Apesar do bom resultado na usinagem do aço AISI 440C, ainda é necessário realizar estudo mais aprofundado, com variação dos parâmetros de corte, para obtenção de maior eficiência global do processo de usinagem e maior produtividade.

Outro diferencial observado no método de refrigeração criogênico foi o fluxo de nitrogênio líquido direcionado para a região do corte pela parte inferior do inserto. Entende-se que a injeção do fluido refrigerado pela parte inferior do inserto oferece maior eficiência de troca térmica da aresta de corte, uma vez que não possui obstrução do caminho pelo cavaco (7)

A integridade superficial da área usinada pode ser observada no gráfico da Figura 4, com a análise comparativa da rugosidade frente aos métodos de refrigeração de corte avaliados.

Como pode ser observado na Figura 4, nos casos estudados, a rugosidade da superfície usinada teve comportamento contrário ao entendimento básico sobre a correlação da rugosidade superficial com o desgaste da ferramenta. Entende-se que a evolução da rugosidade da superfície usinada tem relação direta com a evolução do desgaste da aresta de corte do inserto. No entanto, isso não foi observado neste estudo.

Figura 4 - Rugosidade da peça ao longo do tempo de usinagem

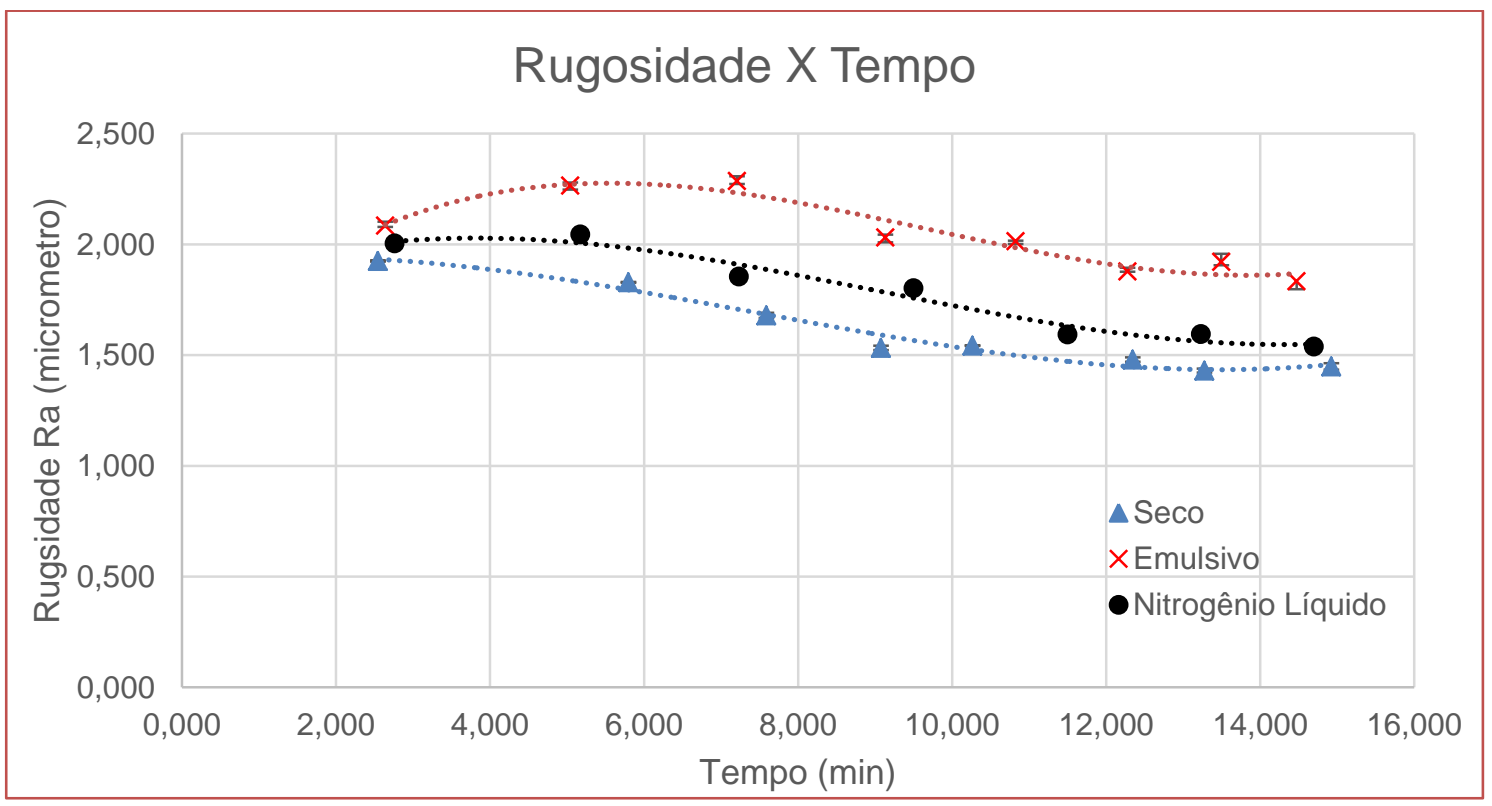

Fonte - Próprio autor

Estima-se que esse comportamento tem relação com o arredondamento da aresta de corte. Isso decorrente do atrito gerado pela extração do cavaco dos primeiros passes. 0 arredondamento da aresta de corte tende ao alisamento da superfície usinada do material AISI 440C, pois uma parte da aresta acaba conformando o material e isso reduz a rugosidade superficial.

No entanto, a refrigeração criogênica seguiu a mesma linha de tendência dos demais métodos de refrigeração analisados, porém os valores de rugosidade Ra mantiveram-se entre os métodos a seco e líquido emulsivo.

Acredita-se que a baixa temperatura do nitrogênio líquido confere uma estabilização térmica do corte e isso, de certa forma, pode ter contribuído com uma maior fragilização do cavaco a cada ciclo de usinagem. A fragilização tem relação com características metalúrgicas do material AISI 440C. Por esse motivo, mais estudos devem ser realizados, com mais tempo de usinagem e alterando os parâmetros corte, a fim de obter mais informações e melhorar o entendimento sobre esse estudo de caso. 


\section{CONSIDERAÇÕES FINAIS}

Neste estudo o inserto TMMG160404MQ classe CA6525, na usinagem do aço inoxidável AISI 440C, no tempo de 15 minutos de usinagem adotado na metodologia não foi suficiente para atingir o critério de fim de vida de ferramenta com $\mathrm{Vb}$ médio de $0,3 \mathrm{~mm}$ ou $\mathrm{Vb}$ máximo de $0,6 \mathrm{~mm}$. Isso significa que a tecnologia do inserto suporta os parâmetros de corte desse estudo

A refrigeração com líquido emulsivo mostrou-se ineficiente, sendo assim o seu emprego é menos indicado para a usinagem desse material com esse tipo de inserto e parâmetro de corte.

A refrigeração criogênica com nitrogênio líquido mostrou-se efetivo na extração de calor da ferramenta, dentre os métodos analisados.

A menor taxa de desgaste do flanco da ferramenta de corte foi observada no método de refrigeração criogênica.

A refrigeração na parte inferior do inserto, a qual foi aplicada no método criogênico, apresenta maior eficiência na introdução do fluido refrigerante na região do corte.

0 corte a seco apresenta inicialmente uma menor rugosidade da superfície usinada. Isso pode ter relação com um suposto alisamento e arredondamento do raio da aresta de corte.

Mais estudos sobre a refrigeração criogênica devem ser realizados para observar o comportamento do degaste de flanco e rugosidade superficial, frente ao maior tempo de usinagem.

\section{AGRADECIMENTOS}

Os autores agradecem o IFC campus Luzerna por ceder o espaço, instrumentos, equipamento e insumos para a realização desta pesquisa. Também agradecem a empresa Kyocera pelas informações técnicas solicitadas e o Laboratório de Ensaios Metalúrgicos (LABEMM).

\section{REFERÊNCIAS}

[1] BORDIN, A. BRUSCHI, S. GHIOTTI, A. BARIANI, P.F. Analysis of tool wear in cryogenic machining of additive manufactured Ti6Al4V alloy Wear 328-329(2015) 89-99

[2] YILDIZ, Y. NALBANT, M. A review of cryogenic cooling in machining processes International Journal of Machine Tools \& Manufacture 48 (2008) 947-964

[3] VICENTIN, G. C.; SANCHEZ, E. D. Â. PORTA-FERRAMENTA PARA USINAGEM COM REFRIGERAÇÃO INTERNA. III Seminário da Pós-Graduação em Engenharia Mecânica, 2009 . Disponivel em: http://www2.feb.unesp.br/pos/seminario/IIISeminario/anais.php. Acesso em 23 de abril de 2018.

[4] KYOCERA CORPORATION. Kyocera Cutting Tools. [S.l.]: Advencing Productivity, 2016.

[5] RGPBALLS S.R.L. RGPBALLS. ESFERAS EM AÇO INOXIDÁVEL AISI 440C, 2018. Disponivel em: <https://www.rgpballs.com/pt/esferas-em-a\%C3\%A7o-inoxid\%C3\%A1vel-aisi-440c/>. Acesso em: 07 ago. 2018.

[6] ASSOCIAÇÃO BRASILEIRA DE NORMAS TECNICA. NBR ISO 3685:Ensaio de de vida util de ferramenta de ponta única para torneamento. Rio de Janeiro, p. 61. 2017.

[7] FERRARESI, D. Fundamentos da Usinagem dos Metais. São Carlos: Editora Edgard Blucher LTDA., 1969.

[8] MACHADO A.R., COELHO R.C, ABRÃO AM et al. Teoria da Usinagem dos Materiais, editora: Blucher 1ํㅡㄹ edição, 2009 (ISBN: 978-8521204527)

[9] GRUB, André Mangetti. Evaluation of the Performance of Contaminated Cutting Fluids when Turning AISI 304 Austenitic Stainless Steel. 2013. 130 f. Dissertação (Mestrado em Engenharias) - Universidade Federal de Uberlândia, Uberlândia, 2013. 


\section{Capítulo 5}

Tratamento de nitretação para melhoria de superfícies erodidas

\section{Gustavo César Pamplona de Sousa}

Marcone Andrade Farias

Resumo: A modificação da superfície de moldes e matrizes por processos de difusão de nitrogênio tem grande aplicação na indústria de injeção plástica. E a usinagem por eletroerosão é um processo capaz de usinar peças de perfis complexos e mais detalhados e de dureza elevada, tendo grande aplicação nesta área. Neste trabalho, foi analisada a aplicação do processo de nitretação em superfícies acabadas por eletroerosão em diferentes amperagens. A partir de ensaios de microdureza e análise metalográfica, constatou-se que após usinada em baixa amperagem ou para desbaste é possível aplicar o endurecimento superficial da nitretação sem a necessidade de retífica e polimento.

Palavras-chave: nitretação, eletroerosão, camada branca, microestrutura. 


\section{INTRODUÇÃO}

A combinação dos vários elementos químicos disponíveis na natureza para o desenvolvimento de ligas ferrosas visando atender às diversas aplicações industriais tem limitação quando se trata de melhorar as propriedades da superfície.

O processo de injeção é caracterizado por uma alta exigência de desempenho de suas matrizes e moldes. A submissão a ciclos de trabalho sob alta temperatura e o atrito com a matéria-prima escoante, faz com que haja um elevado desgaste das matrizes e moldes. Isto tem impulsionando pesquisas no sentido de minimizar este desgaste abrasivo. Uma das soluções adotadas, ao longo do tempo, para aumentar as propriedades das superfícies das matrizes, é a sua modificação por processos de difusão de nitrogênio, técnica conhecida como nitretação. Estas, são normalmente construídas em aço ferramenta, sendo posteriormente temperadas e revenidas, com grande aplicação na indústria de injeção de alumínio, injeção de plástico, conformação a frio e a quente. A indústria disponibiliza processos de difusão e de revestimentos como também processos combinando ambos para as diversas aplicações de moldes e matrizes. Melhorar o desempenho da superfície implica em melhor qualidade de produto final e, sobretudo, incremento da vida útil do molde.

A submissão do aço à têmpera e ao revenimento propiciam as modificações desejadas na estrutura do aço, assim, diversas propriedades são melhoradas, tais como a dureza, a usinabilidade, a resistência ao desgaste e à corrosão (YOSHIDA, 2002; LIMA E CORRÊA, 2006; \& UDDEHOLM, 2006). Todavia, há um forte efeito colateral, a transformação martensítica, apresentando um "fator de empacotamento" menor, causa "crescimento" da estrutura, consequentemente, necessitando de usinagem para se cumprir tolerâncias dimensionais.

0 processo de nitretação é o mais utilizado para melhorar as propriedades mecânicas de superfície de moldes e matrizes. Embora não alcance as mesmas qualificações de dureza e resistência, não causa alterações dimensionais (pelo menos, não significativas) e ainda apresenta uma propriedade importantissíma para estas aplicações, que é conferir a superfície tratada, um caráter não metálico, fazendo com que diminua drasticamente o desgaste abrasivo, melhorando ainda a resistência à corrosão e a fadiga térmica. A indústria disponibiliza processos em meio líquido (sal fundido), gás (amônia dissociada) e plasma (mistura de íons, átomos, moléculas e elétrons).

No processo de eletroerosão por penetração, uma ferramenta reproduz a cavidade por meio de um eletrodo que dá forma às peças. É um processo conveniente para usinar peças que seriam difíceis de serem trabalhadas pelos processos convencionais, seja pela complexidade da geometria e/ou dimensões, seja pela dureza do material. Tem grande aplicação na confecção de matrizes para estampas e corte, moldes de injeção, forjaria, cunhagem e fabricação de ferramentas de aço rápido e de metal duro.

Algumas características são inerentes aos trabalhos executados por eletroerosão, que apresentam na superfície um ligeiro endurecimento e a formação de uma camada superficial com microestrutura, composição química e propriedades distintas do material original, tais como resistência à corrosão, resistência ao desgaste abrasivo, dureza e propriedades mecânicas em geral. Essa camada superficial formada é denominada camada branca.

Esta pesquisa tem como objetivo analisar a aplicação do processo de nitretação em superfícies acabadas por eletroerosão e levantar um estudo das vantagens e desvantagens desse processo.

\section{MATERIAIS E MÉTODOS}

\subsection{AÇOS DE ALTA RESISTÊNCIA E BAIXA E LIGA}

A pesquisa foi realizada com aço ARBL (Alta resistência e baixa liga), são aços que possuem baixo teor de carbono e baixo teor de liga, mas altos limites de resistência. Estes aços possuem aspectos físicos, químicos e econômicos que favorecem sua aplicação em matrizes de injeção plástica. Um aço típico possui normalmente menos que 0,15\% de Carbono, 1,65\% de Manganês e níveis baixos (abaixo de 0,035\%) de Fósforo, enxofre e outros elementos. A resistência destes aços é aumentada pela adição de pequenas quantidades de elementos de liga. Um aço ARBL com uma porcentagem de 0,1 a 0,75\% de Níquel beneficia a sua qualidade superficial. 


\subsection{CORTE E USINAGEM DAS AMOSTRAS}

O corte das amostras foi realizado por eletroersosão na Oficina Mecânica da Universidade Federal de Campina Grande, Campus Campina Grande (PB) numa máquina Eletroerosão Novick AR2300, como podemos observar na Figura 1. O aço ARBL foi cortado nas medidas 10 × 6 × $10 \mathrm{~mm}$.

Figura 1: Processo de eltroerosão por penetração realizada na Universidade Federal de Campina Grande

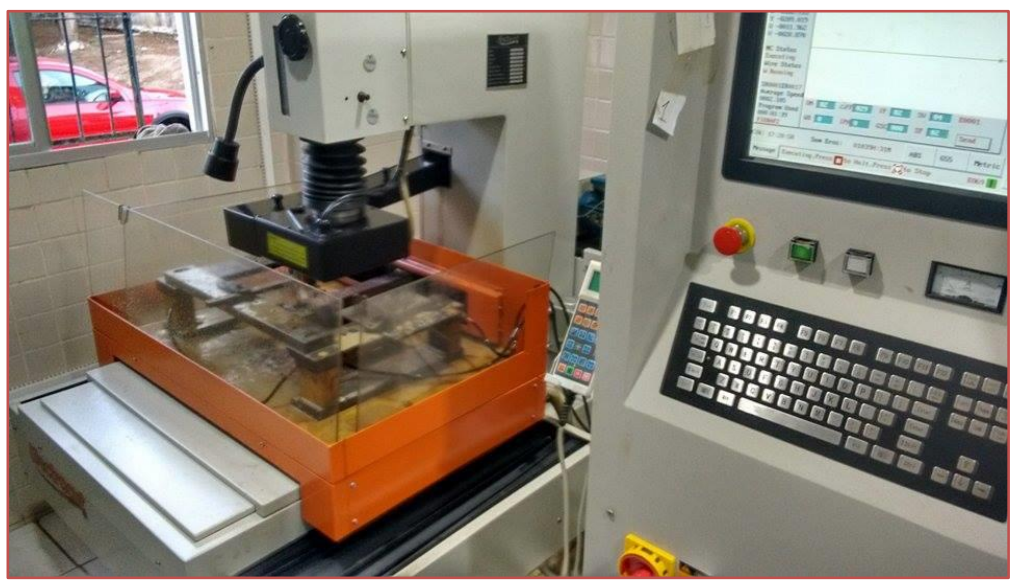

As amostras foram cortadas em três amperagens diferentes e foram denominadas codificações nas amostras. "Classe A", amperagem para acabamento; “Classe B" amperagem mediana e "Classe C" para uma amperagem mais alta (bruta). Foram estudadas duas amostras de cada amperagem e os parâmetros de usinagem utilizados na eletroerosão são mostrados na Tabela 1.

Tabela 1: Parâmetros de Usinagem utilizados nas Classes A, B e C.

\begin{tabular}{|c|c|c|c|}
\hline Parâmetros & Classe A & Classe B & Classe C \\
\hline Marca do parâmetro & E0003 & E0108 & $18 \mu \mathrm{s}$ \\
\hline On & $03 \mu \mathrm{s}$ & $08 \mu \mathrm{s}$ & $59 \mu \mathrm{s}$ \\
\hline Off & $29 \mu \mathrm{s}$ & $49 \mu \mathrm{s}$ & $5 \mathrm{~A} / \mathrm{cm}^{3}$ \\
\hline Corrente & $3 \mathrm{~A} / \mathrm{cm}^{3}$ & $4 \mathrm{~A} / \mathrm{cm}^{3}$ & $380 \mathrm{~V}$ \\
\hline Potência & $380 \mathrm{~V}$ & $380 \mathrm{~V}$ & Automático \\
\hline Gap & Automático & Automático & 06 \\
\hline Norma do gap & 04 & 04 & Velocidade alta \\
\hline Velocidade da alimentação do fio & Velocidade alta & Velocidade alta & Pulso retangular \\
\hline GSC & Pulso retangular & Pulso retangular & Emulsão JH03 \\
\hline Dielétrico & Emulsão JH03 & Emulsão JH03 & $59 \mathrm{~mm}^{2} / \mathrm{min}^{2}$ \\
\hline Eficiência do corte & $8 \mathrm{~mm}^{2} / \mathrm{min}$ & $35 \mathrm{~mm}^{2} / \mathrm{min}$ & $3,5 \mu$ \\
\hline Espessura Ra & $2,3 \mu$ & $2,5 \mu$ & \\
\hline
\end{tabular}

\subsection{CARACTERIZAÇÃO MECÂNICA E FÍSICA DAS AMOSTRAS}

Após a usinagem por eletroerosão, foram realizados os testes de microdureza nas amostras erodidas sem um acabamento superficial prévio, a fim de analisar a dureza da superfície erodida com tratamento de nitretação. Contudo, houve certa dificuldade na medição de microdureza devido a desregularidade da superfície resultante do acabamento por eletroerosão.

A análise de microdureza foi efetuada em um micro-durômeto Shimadzu.com no Laboratório de Materiais da Unidade Acadêmica de Engenharia Mecânica da Universidade Federal de Campina Grande.

0 ensaio foi realizado com carga de 30 gf e com um tempo de permanência de 30 segundos. Para a obtenção dos perfis foram usadas dez profundidades crescentes. O objetivo desta análise foi estudar a influência da camada branca na microdureza antes e depois de aplicar o tratamento de nitretação. Foram 
ensaiadas 02 amostras do Aço ARBL da Classe A, 02 amostras do Aço ARBL da Classe B e 02 amostras Aço ARBL da Classe C.

\subsection{CARACTERÍZAÇÃO MORFOLÓGICA}

A análise metalográfica também foi realizada no Laboratório de Materiais do Departamento de Engenharia Mecânica da Universidade Federal de Campina Grande. 0 objetivo desta análise foi estudar a influência da camada branca na microestrutura do material das amostras, antes de depois de ser aplicado o tratamento de nitretação e, observar a formação de microtrincas. Para cumprir esta finalidade foram ensaiadas 02 amostras do Aço ARBL na Classe A, 02 amostras do Aço ARBL na Classe B e 02 amostras Aço ARBL na Classe C. Todas as amostras antes da análise sofreram limpeza por algodão com álcool e foram secadas por ar quente por 10 min. Para proteção contra a oxidação foi utilizado vaselina.

\subsection{NITRETAÇÃO A BANHO DE SAL}

O tratamento de nitretação foi feito em uma empresa do campo fabril da cidade de Campina Grande. Empresa especializada em extrusão de alumínio que também trabalha com tratamento de matrizes de injeção.

Foi realizado pré-aquecimento a $350^{\circ} \mathrm{C}$ por 60 minutos e 2 horas ao sal CR4 com temperatura de $(570 \pm$ 5) ${ }^{\circ} \mathrm{C}$. As amostras foram resfriadas a temperatura ambiente. Na Figura 2, observamos a amostra mergulhada em taque d'água para limpar os vestígios de sal.

Figura 2: Retirada dos resquícios de sal.

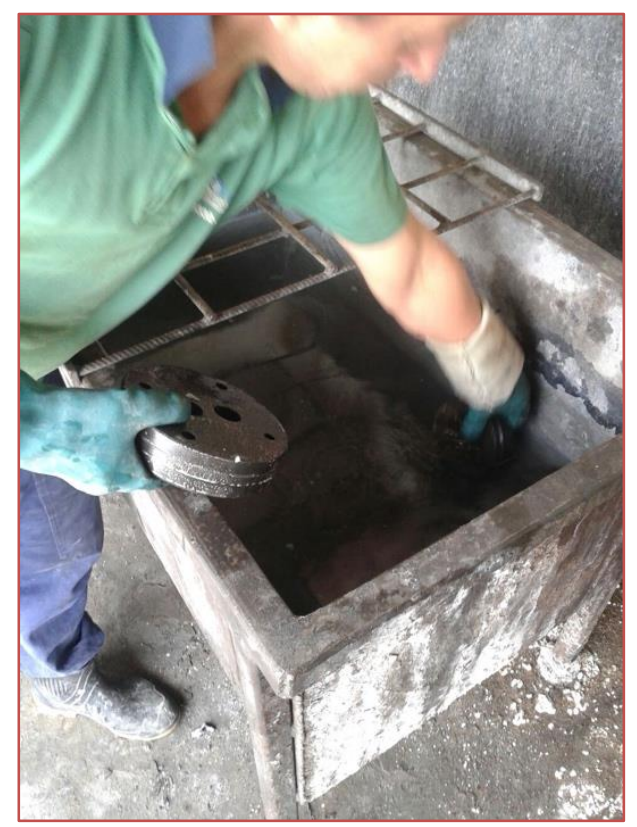

As amostras foram colocadas em uma pequena armação de aço vazada que foi posta na cesta com as amostras da empresa. Não foi permitido pela empresa fotografar, mas nos foi fornecido algumas imagens do processo de Nitretação que a empresa executa como podemos observar na Figura 3. Desse modo as amostras foram nitretadas no mesmo lote, evitando qualquer desregularidade no processo e foi pensado também em não interromper as atividades de nitretação da empresa. 
Figura 3: Nitretação a banho de sal.

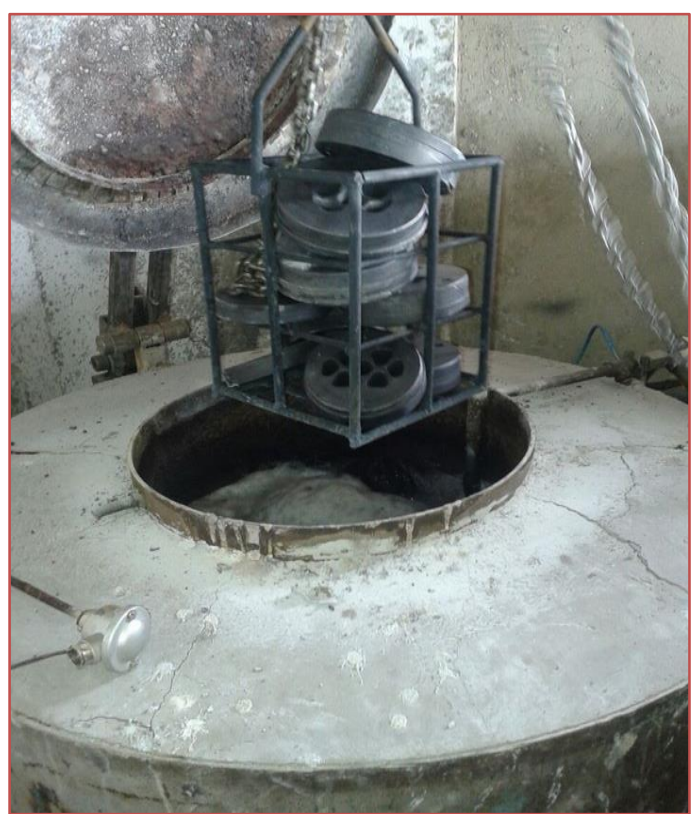

\section{RESULTADOS E DISCUSSÃO}

\subsection{MICRODUREZA}

A microdureza do aço ARBL antes da usinagem por eletroerosão e do tratamento de nitretação conferiu em $304 \mathrm{HV}$.

As amostras que foram usinadas com baixa amperagem, Classe A, apresentaram uma dureza de 423,35 HV com um desvio padrão de mais ou menos 3,72. Após a nitretação houve uma melhoria na dureza superficial para 600,25 HV com um desvio de mais ou menos 2,6 HV.

As amostras usinadas com média amperagem, Classe B, apresentaram uma dureza de 580,44 HV com desvio de mais ou menos 5,61. E depois da nitretação houve um aumento na dureza para 879,91 HV com desvio de mais ou menos 3,35.

As amostras erodidas com alta amperagem apresentaram uma dureza bastante elevada comparada com a dureza natural do aço ARBL em estudo, o aço apresentou uma dureza de 800,43 HV com desvio padrão de mais ou menos 9,6 HV. E depois da nitretação, uma dureza de 900,4 HV com desvio de 6,02 HV.

Percebe-se que as amostras erodidas apresentaram uma dureza mais elevada do que a dureza natural do aço ARBL, isto se dá devido à liberação de carbono pelo eletrodo de grafite ou fluido dielétrico resultando em um aumento do teor de carbono na área correspondente a camada branca.

\subsection{ANÁLISE METALOGRÁFICA}

A análise metalográfica nos trouxe resultados sobre a possibilidade de aplicar a nitretação após a usinagem por eletroerosão sem a necessidade de retifica e demais meios de retirada da camada branca. A Figura 4 representa a face erodida de uma amostra Classe A, sem o tratamento de nitretação ampliada em 200x. É possível observar presença de microtrincas vistas no perfil da amostra. 
Figura 4: Perfil de baixa amperagem ampliada em 200x.

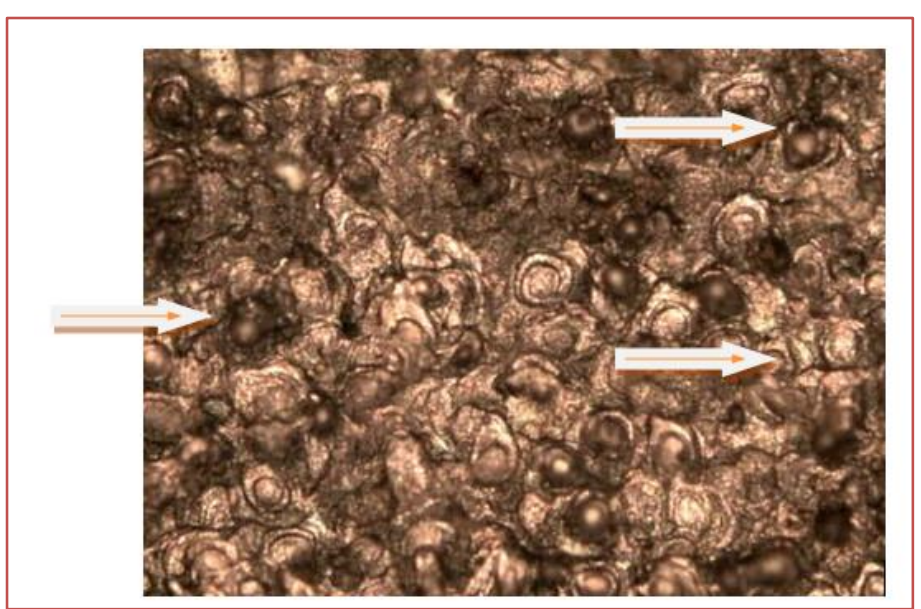

Na Figura 5, nota-se que após a nitretação da amostra Classe A, as microtrincas não aparecem mais.

Figura 5: Perfil nitretado da amostra com baixa amperagem ampliada 200x.

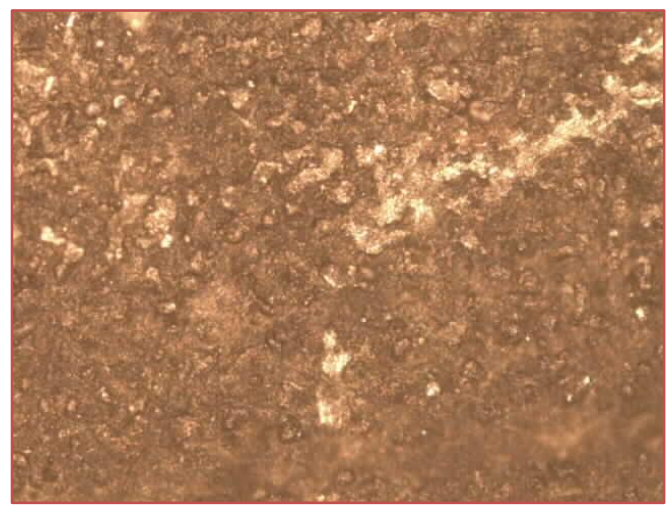

Assim como é apresentada na literatura, quanto mais severa a amperagem, mais profunda a camada branca e maior a presença de microtrincas. Na Figura 6, temos a microscopia da superfície erodida de uma amostra Classe B seguida do perfil nitretado da mesma amostra, ambas ampliadas em 200x. Nota-se que a aparição de microtrinas diminuiu, mas ainda aparecem.

Figura 6: Perfis de média amperagem antes e depois da nitretação, ampliada 200x.

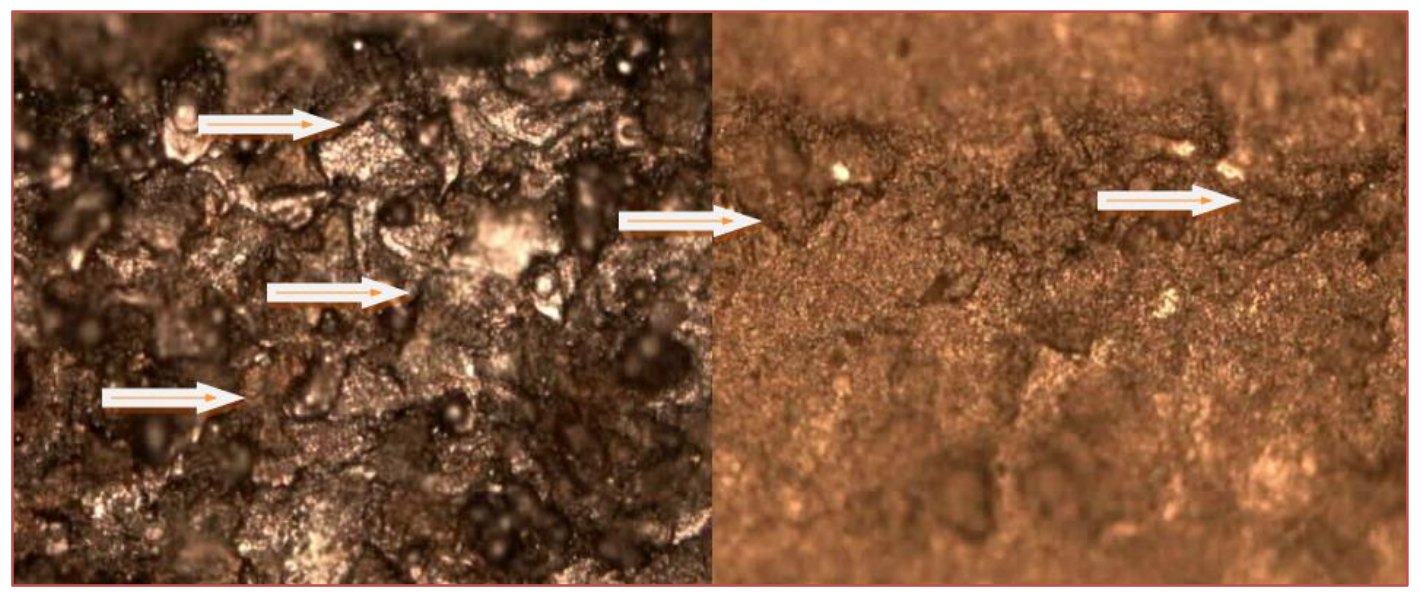


Na Figura 7, podemos observar a microscopia do perfil da amostra com alta amperagem seguida do seu perfil após a nitretação. Percebe-se o acabamento cada vez mais severo, condizendo com a literatura.

Figura 7: Perfis de alta amperagem antes e depois da nitretação, ampliada 200x.

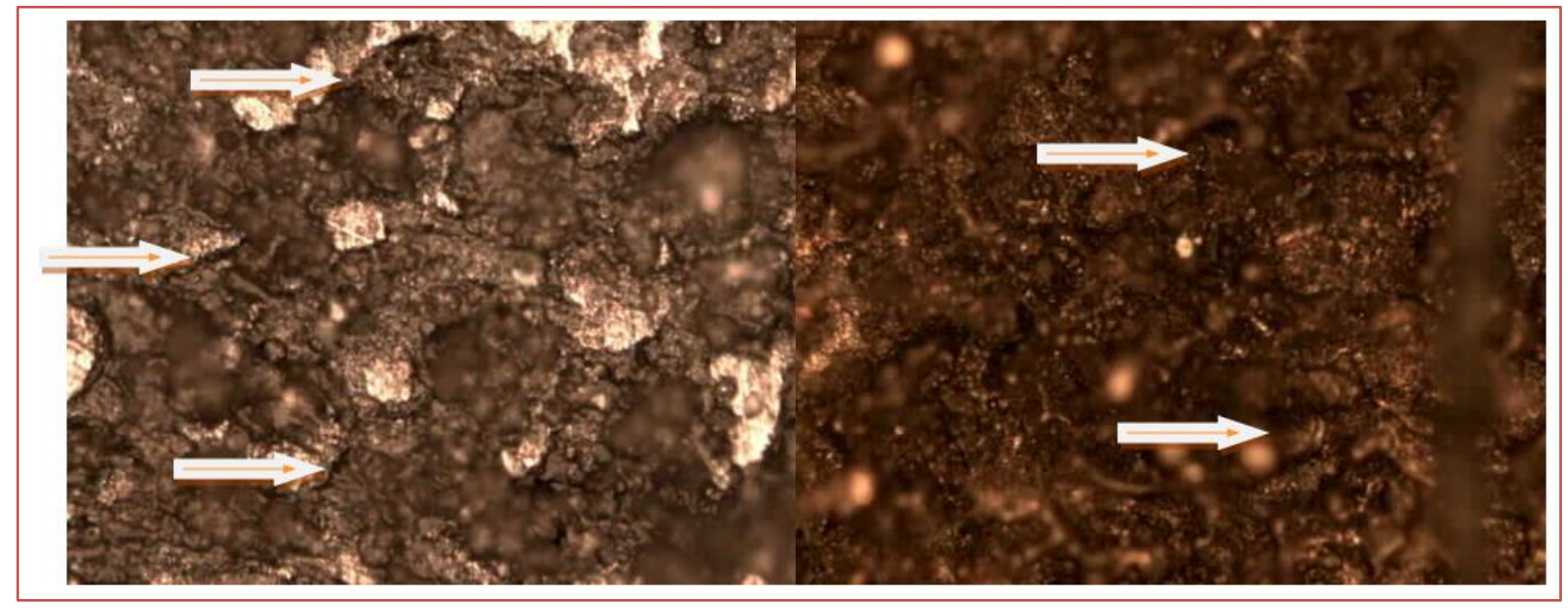

Uma visão lateral da amostra Classe C foi capturada na micrografia antes da nitretação, como se pode observar na Figura 8. Percebe-se a camada branca bem acentuada, uma vez que os parâmetros de usinagem para essa classe foram mais severos.

Figura 8: Perfil lateral de uma amostra da Classe C, antes do tratamento de nitretação.

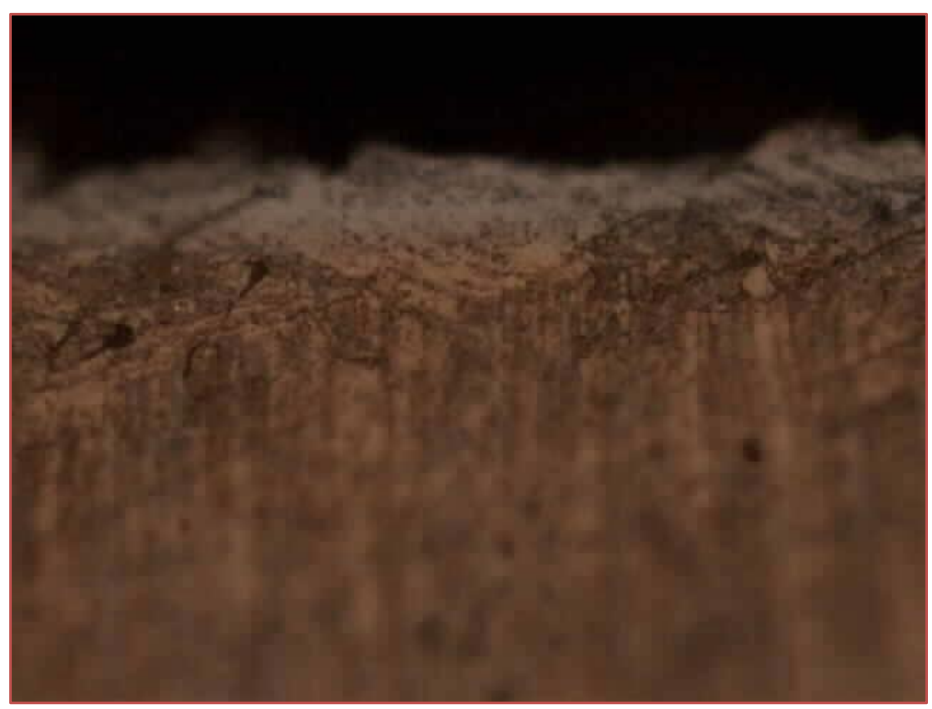

\section{CONCLUSÃO}

Condizendo com a literatura, conferiu-se a necessidade de um acabamento prévio para retirada da camada erodida a fim de obter uma integridade superficial adequada (ausência de microtrincas e camada branca) para receber o tratamento superficial de nitretação. Contudo, através da microscopia notamos que quando usinada em baixa amperagem é possível aplicar o endurecimento superficial da nitretação sem a necessidade de retífica e polimento. Mas, quanto mais severas as condições de usinagem por eletroerosão, maior a necessidade de preparar superficialmente as amostras, antes do tratamento de nitretação, como podemos observar na análise metalográfica, os perfis que foram usinados com média e alta amperagem ainda ficaram com ocorrência de microtrincas, após o endurecimento superficial da nitretação. 
Com os perfis de microdureza observamos um menor desvio dos resultados abordados nos testes após a nitretação, isso foi ainda mais perceptível na baixa amperagem. Algumas dificuldades estiveram presentes na leitura da microdureza na face erodida. 0 acabamento por eletroerosão está distante do nível de retífica, podendo ser considerado inadequado para "deslizamentos entre metais" devido à camada refundida. Também se observou desvios consideraveis nos valores de micro dureza, o que já era esperado, devido a heterogeneidades na microestrutura da camada branca.

Aplicado a moldes de injeção e outras matrizes, superfícies erodidas e nitretadas, sem melhoria no acabamento, submetidas a alta pressão de injeção ficam sujeitas a trincas tipo casca de ovo, devido a natureza pobre da microestrutura após a eletroerosão.

Atenta-se que a microdureza da superfície é mais elevada do que a do núcleo do substrato, isso ocorre porque a zona refundida sofre alterações de composição química e pode sofrer também uma espécie de têmpera, devido a alta temperatura alcançada e o rápido resfriamento, possibilitado pela extração de calor do dielétrico e da própria massa da peça que é muitíssimo maior que a massa da camada refundida, assim se a camada afetada, inclusive termicamente, é apenas da ordem de milímetros.

Por fim, vimos que de fato é mais viável, assim como mencionado na literatura, um tratamento superficial da peça antes da nitretação. Mas ainda é possível realizar o tratamento sem retífica e polimento se a peça tiver sido usinada em baixa amperagem ou apenas para desbaste.

\section{REFERÊNCIAS}

[1] CHIAVERINI, Vicente. Tratamentos Térmicos das Ligas Metálicas. ABM - Associação Brasileira de Metalurgia e Materiais. São Paulo, 2003.

[2] CHIAVERINI, Vicente. Tecnologia Mecânica. 2 Ed. São Paulo: McGraw-Hill, 1986.

[3] CRUZ, C.; MALAQUIAS, E. S.; \& FERNANDES, L. A. Introdução à usinagem não tradicional. Uberlândia, MG: DEEME, UFU, 1999, p. 7-19.

[4] FULLER, J. E. Electrical discharge machining. 9th Ed. Terre Haute: Joseph R. D., Metals Handbook Machining, v. $16,1989$.

[5] LAZZARINI, F. A. S.; YAMAKAMI, W. J.; \& CRUZ JUNIOR, E. J. Estudo das superfícies obtidas por eletroerosão. XXVII Congresso de Iniciação Científica da Unesp. São Paulo: 2015

[6] KLOCKE, F; KARDEN, A. Materials Characteristics after cavity sinking by EDM. Production Engineering. V. 6, N. 2. Germany: 1999, p. 35-38.

[7] LIMA, F.; CORRÊA, M. Efeitos da eletroerosão sobre a superfície de peças usinadas. Rev. Tecnol. Fortaleza, v. 27, n. 1. UNICAMP, São Paulo: 2006, p. 26-33.

[8] MÜLLER, Peter; SOTO, Marcos. O HSS está muito vivo! 0 Mundo da Usinagem, 2002. Disponível em: < http://www.omundodausinagem.com.br>. Acesso em: 18 de agosto de 2016.

[9] UDDEHOLM, T. Aços Especiais, “EDM of tool steel”. Editado pela Uddeholm Tooling. Suécia, 2002.

[10] YOSHIDA, S.; VENDRAMIM, J. Seleção de Aços, Tratamentos Térmico e Tratamentos de Superfície para Ferramentas de Conformação de Metais. Congresso de Corte e Conformação, São Paulo, Brasil: 1995. 


\section{Capítulo 6}

Desenvolvimento de equipamento para realização de ensaio de torção em eixo AISI 4340

\section{Mateus Felipe Bald \\ Neimar João Balan \\ Lucas Barp \\ Rodrigo Cardoso Costa \\ David Roza José \\ Fernando Michelon Marques}

Resumo: Nos últimos 5 anos algumas empresas do meio oeste catarinense passaram a aplicar diferenciadas tecnologias na fabricação de componentes mecânicos, por exemplo, a soldagem por fricção dos eixos nos rotores de bombas hidráulicas. Para garantir a qualidade dos rotores soldados é imprescindível testar o conjunto mecânico frente ao ensaio de torção. 0 presente estudo apresenta o desenvolvimento do projeto mecânico de um equipamento para realizar o ensaio de torção, conforme especificidade das aplicações industriais locais. Como resultados obtidos, foi observado que a estrutura do equipamento é capaz de resistir aos esforços durante o ensaio de torção. Os eixos das engrenagens do redutor secundário apresentam robustez frente ao torque calculado para fratura do corpo de prova conforme norma ASTM E 8-03. As engrenagens projetadas para o redutor de velocidade externo também suportam os esforços. Os cálculos realizados conforme bibliografia indicaram que o equipamento projetado possui torque máximo de 3500 N.m.

Palavras-chave: Ensaio; Torção; Equipamento; Projeto. 


\section{INTRODUÇÃO}

Muitas máquinas industriais utilizam eixos para transmissão de potência mecânica. Neste sentido, quando em operação, o material do eixo é constantemente submetido ao esforço de torção. De posse desse conhecimento, os engenheiros mecânicos procuram desenvolver os projetos dimensionais dos eixos, de forma que as tensões tangenciais aplicadas no eixo de interesse não ultrapassem os limites máximos de resistência mecânica do material metálico (1).

A determinação das propriedades mecânicas de um material metálico normalmente ocorre por meio de ensaios mecânicos destrutivos padronizados, por exemplo ensaio de tração, compressão, torção e fadiga. Em todo ensaio destrutivo acontece a ruptura ou a inutilização do corpo de prova, ou seja, o material é forçado ao seu limite máximo de resistência para avaliar sua aplicabilidade (2).

A proposta do ensaio mecânico destrutivo de torção é testar o material de interesse em condições similares às das operações industriais. Neste tipo de ensaio mecânico, um lado do corpo de prova permanece estático, enquanto o outro é rotacionado com potência, velocidade angular e sentido constante. No núcleo do corpo de prova surgem vetores de força que tendem ao cisalhamento do material em planos mutuamente perpendiculares, conforme a hélice de torção do corpo de prova. Esses vetores surgem como resposta de resistência do material ao esforço mecânico de torção. Os esforços internos desenvolvidos no corpo de prova devido ao ensaio de torção podem provocar um estado de tensão que promova a ruptura do material. As informações referentes ao limite de escoamento e a máxima tensão do material são utilizadas para o dimensionamento de eixos, bem como a avaliação de diferentes tipos de materiais metálicos e tratamentos térmicos empregados na fabricação dos mesmos (3).

A fabricação de peças industriais de qualidade é pautada no conhecimento técnico das pessoas envolvidas, no domínio da tecnologia empregada na produção e na organização empresarial. Nem sempre as empresas produtoras de bens e serviços finais estão capacitadas para garantir a qualidade plena de seus produtos (4).

O compartilhamento de conhecimento entre indústria e instituição de ensino tende ao fortalecimento de uma economia local, uma vez que existe a possibilidade da divisão dos custos de pesquisas tecnológicas, da oportunidade de abertura de novos negócios, da promoção de competitividade, e do desenvolvimento sustentável associados a fabricação de produtos com qualidade superior (4).

Com base na capacitação e aperfeiçoamento de arranjos produtivos locais de empresas que fabricam componentes mecânicos submetidos ao esforço de torção, é necessário o desenvolvimento de um equipamento de laboratório que atenda às necessidades técnicas para avaliar a resistência mecânica a torção do material que constitui o produto de interesse. A proposta desse projeto de pesquisa é tornar possível a constatação na prática das informações obtidas via simulação numérica, ou seja, comparar os resultados de resistência à torção frente aos cálculos matemáticos e simulações.

\section{METODOLOGIA}

Para o desenvolvimento do equipamento adota-se metodologia de engenharia reversa, uma vez que o equipamento a ser desenvolvido para ensaio de torção segue referência de resistência ao cisalhamento de um eixo maciço conhecido. Neste estudo, o corpo de prova segue dimensionamento conforme norma ASTM E 8-03. Na Figura 1 podem ser observadas as dimensões nominais do corpo de prova (5).

Figura 1 - Corpo de prova

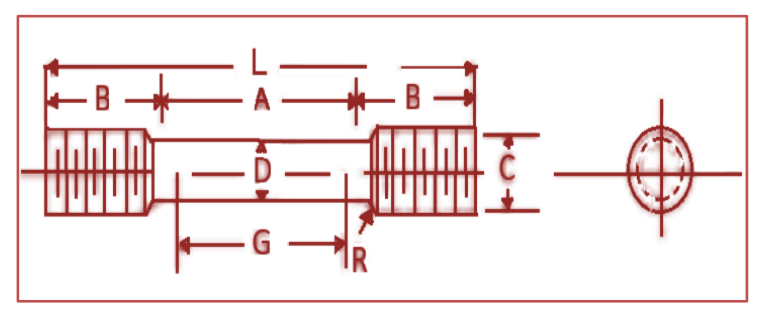

\begin{tabular}{|lcc|}
\hline \multicolumn{3}{|c|}{ Amostra I } \\
\hline & $\begin{array}{c}\text { Dimensão } \\
\text { (in.) }\end{array}$ & $\begin{array}{c}\text { Dimensão } \\
\text { (mm) }\end{array}$ \\
\hline G - Comprimento entre raios & $2.000 \pm 0.005$ & $50,8 \pm 0,127$ \\
\hline D - Diâmetro útil & $0.500 \pm 0.010$ & $12,7 \pm 0,257$ \\
\hline R - Raio & $3 / 8$ & 9,52 \\
\hline A - Comprimento útil & $21 / 4$ min. & 57,15 \\
\hline L - Comprimento total & 5 & 127 \\
\hline B - Comprimento de fixação & $13 / 8$ aprox. & 34,92 \\
\hline C - Diâmetro de fixação & $3 / 4$ & 19,05 \\
\hline
\end{tabular}


Fonte: (ASTM E 8-03)

Na etapa de projeto, cálculos foram realizados referente a resistência à torção de um eixo maciço constituído de aço carbono comum laminado AISI 4340 não temperado. A partir dos resultados obtidos nesses cálculos foram determinados o tamanho das peças estruturais e elementos de máquinas, para adequação do equipamento ao esforço necessário para rompimento do corpo de prova de interesse.

O dimensionamento das partes e componentes segue orientação de resultados das simulações numéricas realizadas pelo software ANSYS R19.1 Acadêmico® do corpo de prova. Já a estrutura metálica foi simulada pelo Autodesk Inventor Professional 2019® Student License.

A simulação numérica do corpo de prova foi realizada conforme resultado dos cálculos convencionais. Estes valores foram utilizados como ponto de partida, pois entende-se que a utilização do software de simulação é válida apenas para prever a deformação do material na região elástica, ou seja, uma previsão teórica do comportamento do corpo de prova frente ao esforço de torção. Na Tabela 1 podem ser analisados os parâmetros limites utilizados no estudo de torção dentro do ambiente virtual do ANSYS R19.1 Acadêmico®.

Seguindo Cittadin sobre ensaio de resistência à torção de materiais metálicos, a rotação do corpo de prova deve ser baixa, de 0,5 a $3 \mathrm{rpm}$. Nesse sentido, foi determinado um segundo redutor de velocidade para adequação desse quesito, uma vez que o motorredutor disponível para o projeto oferece rotação de saída de $16 \mathrm{rpm}$.

Os valores de resistência à torção calculados e simulados do corpo de prova serviram como base para determinar o torque final do equipamento. Para tanto, foi utilizado outro conjunto de equações a fim de constatar a robustez do equipamento frente a torção do corpo de prova. Os valores de resistência à torção do corpo de prova também serviram de referência para determinar a resistência dos elementos mecânicos, como eixos e engrenagens do redutor de velocidade secundário externo.

0 material de referência neste estudo é o aço AISI 4340, laminado maciço e não temperado, para este, a tensão de cisalhamento máxima é de 780,08 MPa. Na Eq. (A) é determinado o momento de torção necessário para a ruptura do corpo de prova. Já a Eq. (B) determina o valor de torque mínimo na saída do redutor primário considerando as perdas relacionadas à deformação do material e atrito dos engrenamentos. Neste caso foi utilizado uma redução de $4 \%$ do torque nominal em cada par engrenado (7-8).

$$
M t=\frac{\pi D^{3} \tau}{16}
$$

Onde: Mt é o torque (N.m); $\tau$ é a tensão de cisalhamento máxima (MPa); D é o diâmetro da seção transversal $(\mathrm{mm})$.

$$
M t r=\frac{M t}{\sum_{n=1}^{n} 0,96^{n} r^{n}}
$$

Onde: Mtr é o momento de torção requerido na saída do redutor primário (N.m); $r$ é a relação de transmissão entre o par engrenado (adm); $n$ é o número de pares engrenados (adm).

\section{RESULTADOS E DISCUSSÕES}

Conforme resolução da Eq. (A), para este estudo de caso, foi determinado que o torque mínimo necessário para romper o corpo de prova em aço AISI 4340 laminado maciço não temperado é de 313,74 N.m. Este pode ser observado na Eq. (C) a seguir.

$$
M t=\frac{\pi(0,0127)^{3} 780080000}{16}=313,74 \mathrm{Nm}
$$


Conforme pode ser observado na Figura 2, a simulação numérica do corpo de prova de interesse identifica as regiões de tensão máxima, bem como a escala de comparação destas tensões.

Tabela 01- Parâmetros de entrada para análise do ensaio de torção do aço AISI 4340.

\begin{tabular}{|c|c|c|}
\hline $\begin{array}{c}\text { Módulo de elasticidade } \\
(\mathrm{GPa})\end{array}$ & $\begin{array}{c}\text { Coeficiente de Poisson } \\
(\mathrm{adm})\end{array}$ & $\begin{array}{c}\text { Momento } \\
\text { Aplicado (N.m) }\end{array}$ \\
\hline 190 & 0,29 & 313,74 \\
\hline
\end{tabular}

Fonte: Matweb. (6)

Figura 2 - Simulação do corpo de prova

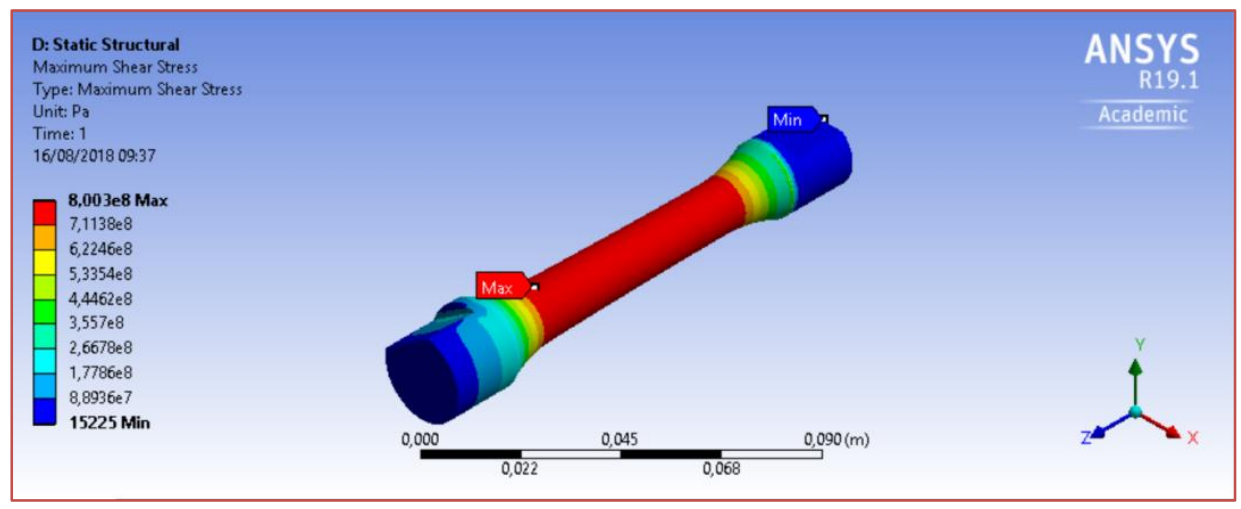

Fonte: Os autores

O valor máximo observado na simulação é de (800,03 MPa), esse valor corresponde aos resultados dentro de um limite elástico para o material conforme o parâmetro utilizado no software ANSYS R19.1 Acadêmico®.

Para atender requisito de baixa rotação foi determinado dois pares de engrenagem que constituem o sistema de engrenamento de um redutor secundário. Tomando como informações a rotação de saída do redutor primário $(16 \mathrm{rpm}$ ) e a rotação do corpo de prova (aprox. $2 \mathrm{rpm}$ ), foi calculado a relação de transmissão entre a entrada e saída do redutor de velocidade secundário. Neste caso, a redução do redutor secundário é de 1:6,25. Isso significa que cada par engrenado terá uma redução de 1:2,5. 0 limite estrutural condiciona o tamanho das engrenagens. Sendo assim, foi estipulado que as engrenagens pinhões serão de 24 dentes e as engrenagens coroas serão de 60 dentes. Para a engrenagem pinhão é observado um diâmetro externo nominal de $104 \mathrm{~mm}$, já a engrenagem coroa é observado o diâmetro externo de $248 \mathrm{~mm}$. Todas as engrenagens serão fabricadas em aço AISI 1045 laminado maciço e não temperado, constituídas de dentes retos, com largura nominal de $50 \mathrm{~mm}$ e módulo 4 (8).

Segundo dados do fabricante do motorredutor SEW R80DZ 90S4BHG, o torque nominal de saída do redutor de velocidade primário é de 617 N.m para potência nominal de $1 \mathrm{~kW}$. Observa-se que esse valor de saída do redutor de velocidade primário é suficiente para romper o corpo de prova de interesse, pois esse torque é cerca de $200 \%$ maior que o torque necessário. 0 redutor de velocidade primário conectado ao redutor de velocidade secundário, o qual apresenta redução de 1:6,25, aumenta o torque muitas vezes na saída. Neste estudo o torque máximo teórico do equipamento para ensaio de torção é de aproximadamente 3500 N.m.

Analisando somente o necessário para romper o corpo de prova, o conceito de equipamento para ensaio de torção na configuração do powertrain, com aproximadamente $9 \%$ da potência do motor já atende a situação de interesse. Estima-se que esta mesma fração da potência nominal do motor corresponde a um torque de saída no redutor primário de 54,46 N.m, cujo valor confere com o resultado da Eq. (2).

Com relação ao eixo das engrenagens do redutor secundário foi adotado o material maciço de aço AISI 1045 laminado não temperado, com diâmetro externo nominal de $50 \mathrm{~mm}$. Esse valor é equivalente ao diâmetro externo do eixo de saída do redutor primário. Conforme a Eq. (1), um eixo com diâmetro externo 
nominal de $50 \mathrm{~mm}$, para este tipo de material, apresenta momento de torção máximo de 17175 N.m. Esse valor é maior do que o momento de torção proporcionado pelo maior engrenamento (engrenagem coroa) do redutor secundário, cujo valor é de 1480 N.m. Em teoria, o eixo de $50 \mathrm{~mm}$ também é superior à capacidade máxima da máquina, uma vez que 17175 N.m é maior que 3500 N.m (8).

Na Figura 3 pode ser observado a segunda versão do projeto conceitual para equipamento de ensaio de torção. Esse equipamento apresenta as seguintes dimensões nominais: altura $1350 \mathrm{~mm}$; largura $500 \mathrm{~mm}$; e comprimento $1550 \mathrm{~mm}$. A altura de operação da máquina está conforme NR-12 e NR-17. A estrutura será fabricada em perfil tubular quadrado 50x50 mm de espessura 2,5 mm de material aço comum AISI 1020, o equipamento possuirá rodízios para movimentação e transporte. Um sistema de posicionamento e fixação das amostras será desenvolvido, por meio de acoplamentos, a fim de facilitar a montagem do corpo de prova no equipamento. Também será desenvolvido um sistema para medição da força de torção, o qual é composto por um braço de alavanca fixada ao acoplamento estático do corpo de prova. Inicialmente o ângulo de torção será aferido por uma escala angular graduada.

Figura 3 - Projeto conceito

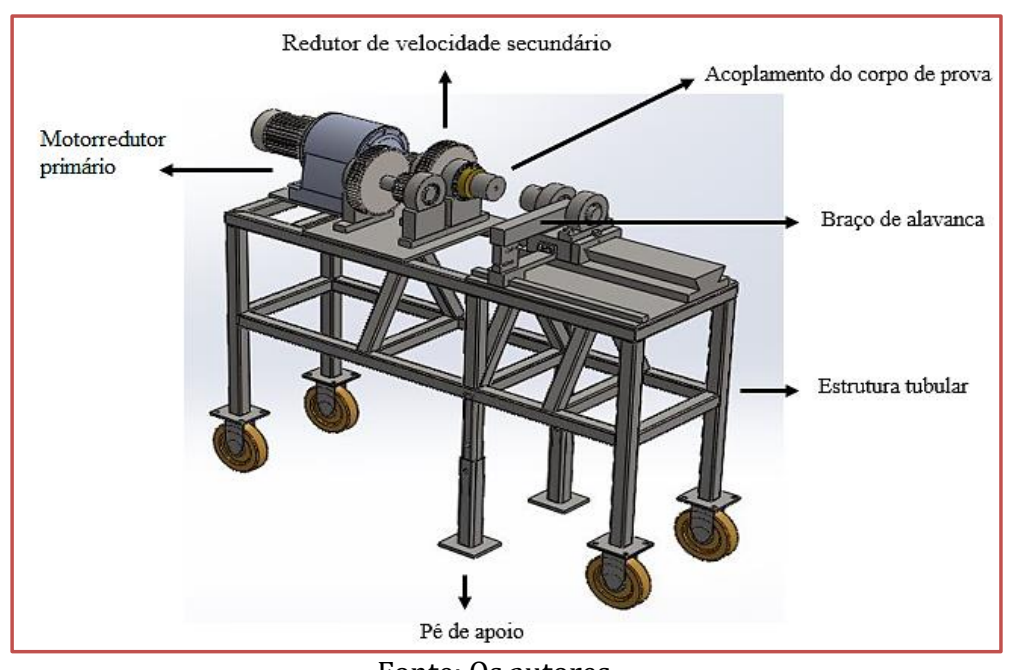

Fonte: Os autores

O ensaio de torção não admite deformações na estrutura do equipamento. Neste sentido, foi desenvolvido o primeiro conceito estrutural do equipamento o qual apresenta quatro pontos de apoio.

Na Figura 4 pode-se observar o resultado da análise gráfica do Software Autodesk Inventor Professional 2019® Student License. Como pode ser observado, para uma força de 12000 N no local onde haverá maior concentração de esforços de flexão, conforme comprimento do corpo de prova (ASTM E 8-03). Nesta análise foi observado uma deflexão máxima na estrutura tubular de 1,27 mm.

Figura 4 - Simulação estrutural sem os pés centrais de apoio

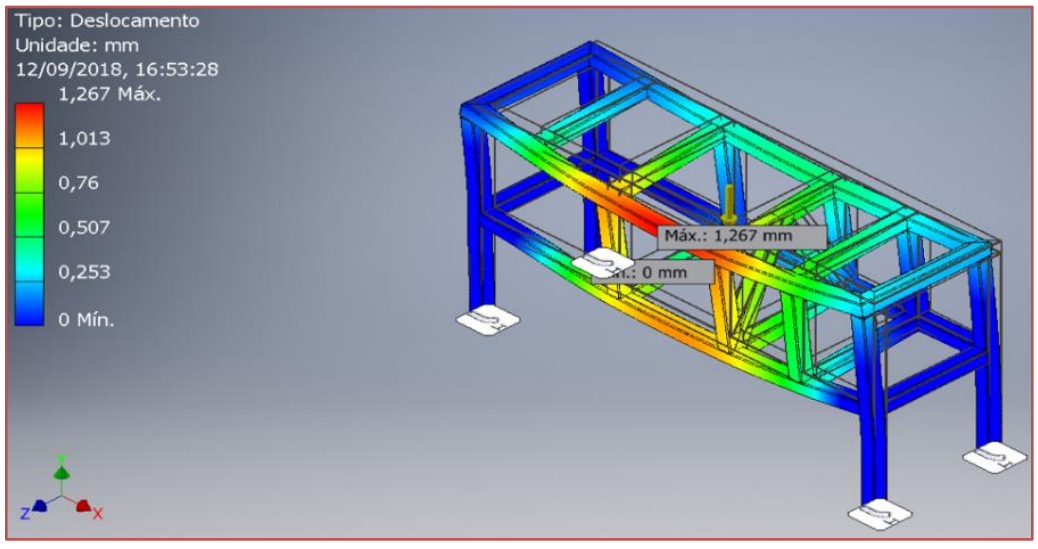

Fonte: Os autores 
Na Figura 5 pode ser observado a alteração do projeto estrutural conceitual. Como diferencial, foram acrescentados dois novos pontos de apoio.

Figura 5 - Simulação estrutural com os pés centrais de apoio

Fonte: Os autores

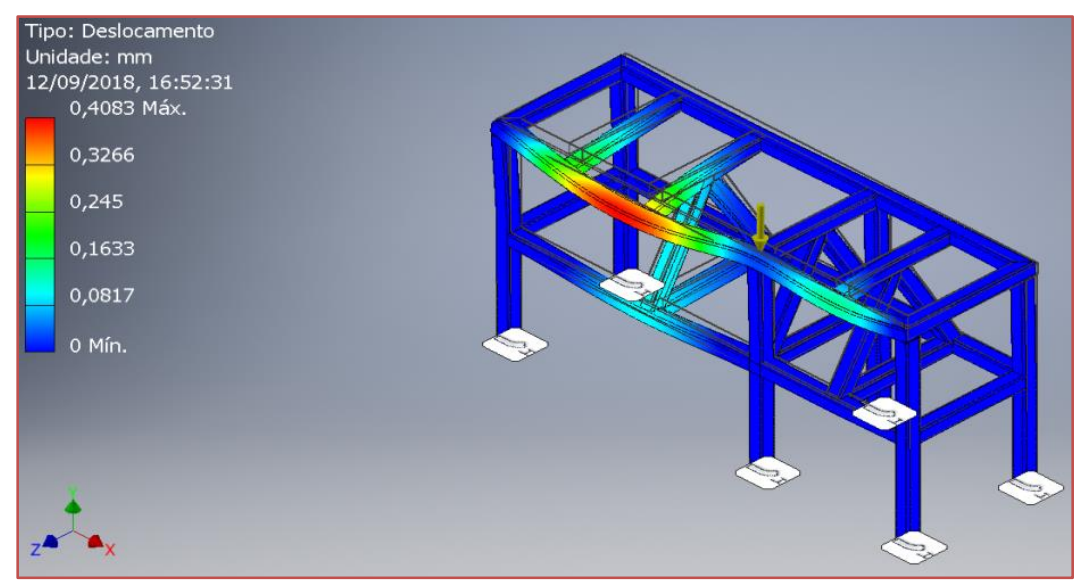

Como pôde ser observado, para a mesma força de 12000 N no local de interesse, foi evidenciada uma menor deflexão estrutural, sendo essa de aproximadamente $0,41 \mathrm{~mm}$. Isso indica que a estrutura com seis pés de apoio apresenta maior robustez.

\section{CONCLUSÃO}

Os cálculos demonstram que os componentes, eixos e engrenagens do redutor secundário possuem momento de torção acima do requerido para romper o corpo de prova em aço AISI 4340 laminado não temperado maciço de diâmetro externo nominal de $12,7 \mathrm{~mm}$.

O equipamento apresenta 3500 N.m como momento de torção máximo, esse valor está bem acima do necessário para romper o corpo de prova de interesse, o qual apresenta como momento de torção um valor teórico de 313,74 N.m. Por ter-se obtido um torque máximo de 3500 N.m, a máquina permitirá ensaios em demais materiais, podendo analisar amplamente elementos e perfis mecânicos comerciais.

A alteração do projeto estrutural conceitual, de quatro para seis apoios, demonstra que a deflexão estrutural será praticamente nula. Isso corrobora para maior robustez e confiabilidade do equipamento, uma vez que o braço de alavanca concentra o máximo do esforço de cisalhamento no corpo de prova.

0 valor da resistência a tensão de cisalhamento máxima no limite elástico estipulada de 800,3 MPa para o material AISI 4340 laminado não temperado maciço de diâmetro nominal 12,7 mm, conforme parâmetros ajustados no software ANSYS R19.1 Acadêmico®, pode ser considerada como um valor de referência, o qual deverá ser comparada na prática mediante análise de valores experimentais.

\section{AGRADECIMENTOS}

0 projeto somente pode ser executado perante financiamento realizado conforme edital da reitoria do IFC № 267/2017. Agradecimento especial ao LABEMM (Laboratório de Ensaios Mecânicos e Metalúrgicos), ao Laboratório de Ciências Termofluidas e ao Instituto Federal Catarinense Campus Luzerna por ceder espaço para a realização deste projeto. 


\section{REFERÊNCIAS}

[1] LEGGERINI M. R. C. Resistência dos materiais I: Notas de aula. Apostila apresentada à Faculdade de Engenharia do Departamento de Engenharia Civil da Instituição Pontifícia Universidade Católica do Rio Grande do Sul - PUCRS. Porto Alegre - RS. 2007.

[2] SOUZA S. A. Ensaios mecânicos de materiais metálicos: Fundamentos teóricos e práticos. São Paulo-SP. 1982.

[3] BALANCIN O. Ensaio de torção. Laboratório Termomec. Universidade de São Carlos. São Paulo-SP. 2015.

[4] CARDoso U. C; Carneiro V. L. N; Rodrigues É. R. Q. APL: arranjo produtivo local. série empreendimentos coletivos - Sebrae. Brasília-DF. 2014.

[5] ASTM. STANDARD TEST METHODS FOR TENSION TESTING OF METALLIC MATERIALS. ASTM E 8-03: Standard test methods for tension testing of metallic materials. United States, 2004. 23 p.

[6] MATWEB. AISI E4340 Steel, normalized, $13 \mathrm{~mm}$ (0.5 in.) round. M434C0 / 7784. Disponível em: <http://www.matweb.com/search/DataSheet.aspx?MatGUID=ef6bd62c5eb34df88cc26ce8d1a2c507>.

[7] CITTADIN, R; MARQUES, F M. Aplicação de Métodos Analíticos para Validação de Ensaio de Torção Realizado em AISI 1045, 4340 e 8640 - Faculdade SATC. Criciúma-SC. 2009.

[8] PROVEnZA,. Francesco. Projetista De Máquinas - PRO-TEC. São Paulo: Provenza, 2010. 490 p.

[9] ANSYS Academic Student. Version 19.1. [S.l.]: ANSYS Inc., 2018.

[10] AUTODESK Inventor Professional for Students. Version 2019. [S.l]: Autodesk Corporation, 2018.

[11] NR, Norma Regulamentadora Ministério do Trabalho e Emprego. NR-12 - Máquinas e Equipamentos. 2009.

[12] NR, Norma Regulamentadora Ministério do Trabalho e Emprego. NR-17 - Ergonomia. 2009.

[13] PROVENZA,. Francesco. Projetista De Máquinas - PRO-TEC. São Paulo: Provenza, 2010. 490 p. 


\section{Capítulo 7}

\section{Caracterização microestrutural, química e microdureza dos aços inoxidáveis}

\section{Josué Boaroli \\ Fernando Michelon Marques \\ Rodrigo Cardoso Costa \\ Alexandre da Silva Rocha}

Resumo: Hoje é praticamente impossível encontrar alguma área de atividade humana no qual o metal não esteja presente e intimamente ligado ao desenvolvimento. Assim é necessário conhecer suas propriedades e quais ambientes serão utilizados para selecionar o melhor tipo de material a usar. Este estudo investiga alguns dos diferentes aços inoxidáveis austeníticos quanto a composição, microestrutura e dureza.. Para tais análises, foi necessário seguir uma série de procedimentos padrões referente a preparação da amostra, a qual interfere diretamente no resultado fina, microestrutura e durezal. 0 percentual de cromo variou entre 17 e 18\%, característica que dá ao material boa passividade. Já o molibdênio na classe 304 e 304L apresenta-se como teor residual, e no 316 e 316L apresenta-se como elemento de liga. Dentre todos os materiais estudados, o AISI 304 apresentou maior dureza. A relação entre a composição da liga, microestrutura e dureza e as propriedades específicas de cada aço foi discutida.

Palavras Chaves: Metal, Composição Química, Aços Inoxidáveis 


\section{INTRODUÇÃO}

Atualmente comenta-se que as principais necessidades de fabricação para humanidade estão nos setores de alimentos, energia e materiais. Pode-se evidenciar a importância dos materiais buscando historicamente as eras pelas quais o homem passou, sendo lembradas por idade do cobre, idade da pedra, idade do bronze e idade do ferro (1).

Algumas aplicações requerem materiais muito específicos para melhor rendimento, durabilidade e custo benefício da máquina ou equipamento. Desta forma abre-se uma lacuna para a pesquisa sobre metais com características bem peculiares, resistência à corrosão e a oxidação. Com o grande número de meios agressivos existentes, o estudo para suprir tal exigência necessita ser minucioso e preciso. Levando em consideração essas questões, foram desenvolvidos os aços inoxidáveis(2).

Para definição de um metal que atendesse tais necessidades se fez necessário a combinação de elementos químicos que trouxessem as características necessárias. Nessa combinação de elementos químicos, notouse destaque na adição do elemento denominado Cromo $(\mathrm{Cr})$ com percentuais acima de 10,5\%. Este material, entre todos os outros, é o mais importante para resistência à corrosão e oxidação. Este elemento cria uma camada passiva rica em $\mathrm{Cr}$ entre o elemento de contato e o interior do material(3) (4).

Os critérios de especificação e escolha de materiais impõem, para a realização dos ensaios, métodos normalizados que objetivam levantar as propriedades mecânicas e seu comportamento sob determinadas condições e esforços. Essa normalização é fundamental para que se estabeleça uma linguagem comum entre fornecedores e usuários, já que é a pratica comum a realização de ensaios no seu recebimento, a partir de uma amostragem estatística representativa de tal volume recebido. Os ensaios dos materiais são de suma importância para permitir a obtenção de informações rotineiras dos produtos e para desenvolver novas informações, desenvolvimento de novos materiais, novos processos de fabricação e novos tratamentos (5).

Atualmente comenta-se muito utilização dos aços inoxidáveis para implantes, pois este possui propriedades as quais garante a resistência aos fluídos do organismo humano. Os aços inoxidáveis, atualmente, também tem grande destaque no setor alimentício, por assegurar melhor condição de contaminação. Nas indústrias químicas merecem destaque por resistir a mudanças bruscas de temperatura e suportar a corrosão. São empregados em tanques de armazenamento de produtos, tubulações de circulação de materiais, em peças e equipamentos de manipulação (6).

Nessa linha de raciocínio, o objetivo deste artigo foi ressaltar conceitos sobre as microestruturas, comentar e informar aspectos de preparação de amostras, caracterização microestrutural, bem como exibir algumas micrografias (imagens) e resultados de microdureza e composição química. Este artigo poderá ser usado em áreas como controle de qualidade, análise de falhas e pesquisa e desenvolvimento. As análises que foram realizadas, em controle de qualidade, podem ser usadas para determinar parâmetros estruturais, bem como critérios de aceitação ou rejeição de materiais. Essas análises realizadas podem evidenciar se houve qualquer erro no processo de fabricação de determinada peça, ou se as condições de trabalho provocaram alterações no material, sendo assim, seria necessário o estudo para a substituição do material empregado

\section{MATERIAIS E METODOS}

Para realização deste trabalho foram necessários alguns materiais e ensaios que serão relatados a partir deste capítulo, incluindo a metodologia aplicada.

Foi inciado o processo com a separação de barras trefiladas de aço inoxidável AISI 304, AISI 304L, AISI 316 e AISI 316L. Munidos dos materiais em questão, foram cortados corpos de prova, com o auxílio de um torno Romi S-20 A, com dimensões de 20 mm de largura e 15 mm de diâmetro conforme fig. 1. 
Figura 1. Amostras cortadas.

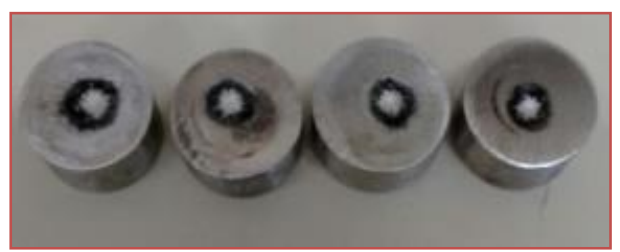

Com os corpos de prova disponíveis, fez-se necessário o seccionamento do corpo de prova, com o auxílio de uma cortadeira metalográfica marca Entex, para que parte desse material fosse direcionado ao ensaio de composição química e o restante direcionada ao embutimento, para preparação até que se chegue ao polimento e ataque químico(7).

Utilizou-se a cortadeira metalográfica indicada pela fig. 2 a, também um disco de corte abrasivo especial para cortadeira metalográfica. Trata-se de um disco de alta qualidade produzido em material abrasivo (AL203), fig. 2 b, e durabilidade para materiais ferrosos, com esse disco a superfície do material após o corte tem melhor acabamento. Acabamento este, quando comparado à outros processos de seccionamento de corpos de prova.

Figura 2.a- Cortadeira metalográfica, b- Disco abrasivo.

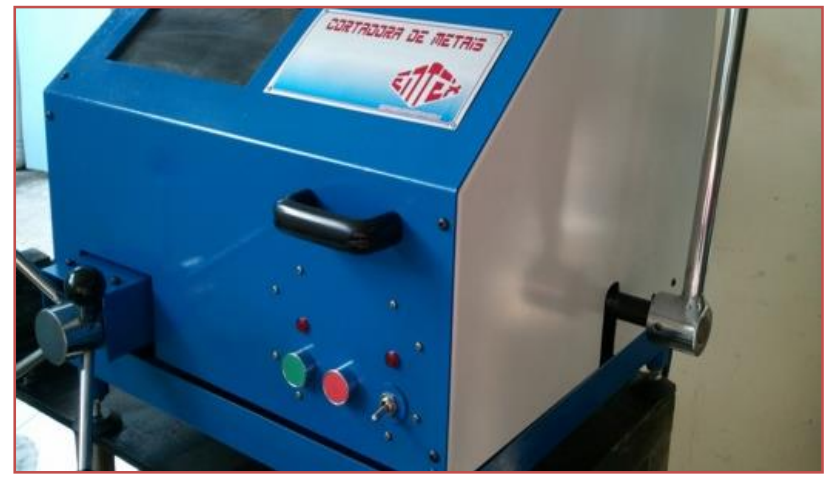

(a)

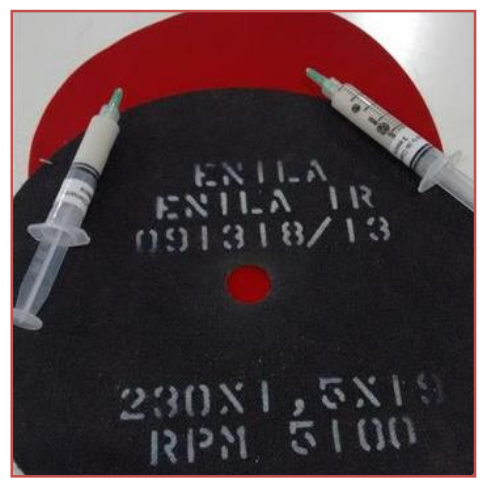

(b)

Para o corte da amostra é necessário que seja feito com cautela para evitar o aquecimento excessivo da amostra. Este aquecimento pode alterar algum fator na estrutura do material, quando posteriormente for analisado sua microestrutura. Para tanto, foi utilizado fluido refrigerante em toda a operação de corte.

A metade do corpo de prova, direcionada para a análise de composição química, foi preparada utilizandose de uma lixadeira metalográfica, fig. 3, com uma lixa d'água de 220 mesh. Assim conseguiu-se uma superfície lisa para acoplamento ao campo de queima do Espectrômetro.

Figura 3. Lixadeira metalográfica.

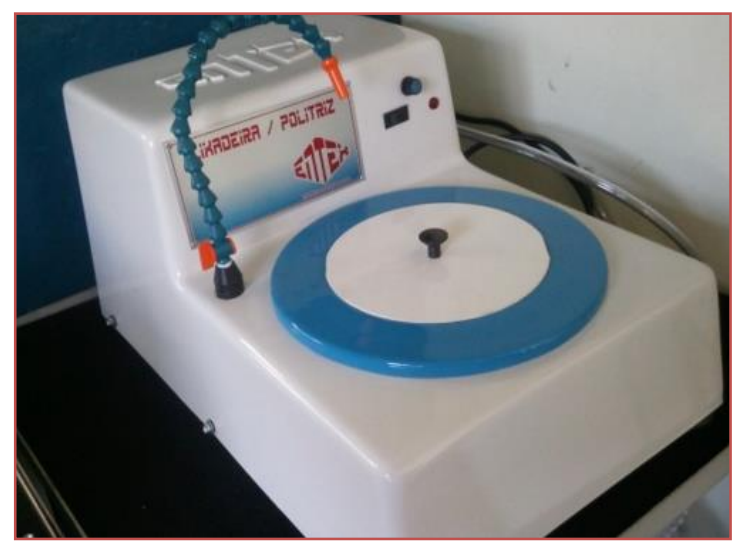


Os quatro materiais indicados foram lixados e preparados para sua posterior análise química. Para determinação da análise química se fez necessário o uso do equipamento denominado "Spectro Lab. Jr", fig. 4. Este equipamento é acoplado a um computador, ao qual, por meio do Software da máquina, revela o percentual de cada elemento químico presente no material. A definição do resultado de cada elemento químico é realizada pela medição de ondas de luz e eletromagnéticas.

Figura 4. Spectrômetro de Emissão Óptica.

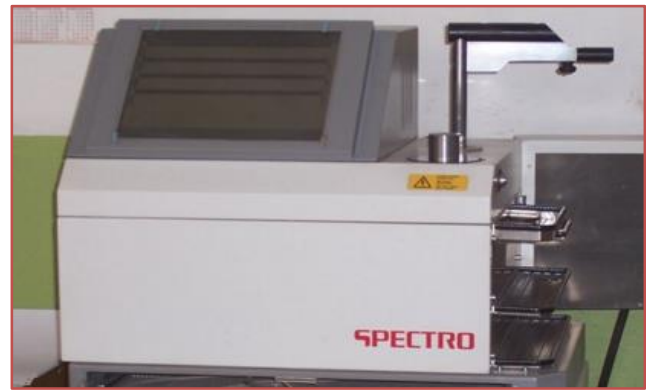

Com as análises realizadas, foi possível verificar o percentual de cada elemento químico presente nas amostras, conforme tabela que será apresentada nos resultados dos ensaios.

Com os resultados apresentados pelo software de composição química, foi dado continuidade aos ensaios de análise metalográfica e microdureza. Para tanto, se fez necessário o embutimento das amostras em resina poliéster automotiva. Fez-se necessário um perfil circular com diâmetro de $50 \mathrm{~mm}$ e despejado a resina misturada com catalisador ao molde em uma proporção de 20 gotas de catalisador para cada $100 \mathrm{ml}$ de resina.. Após um período de 15 minutos, para cada amostra, obteve-se os corpos de prova embutidos e prontos para o lixamento conforme fig. 5.

Figura 5. Amostras embutidas.

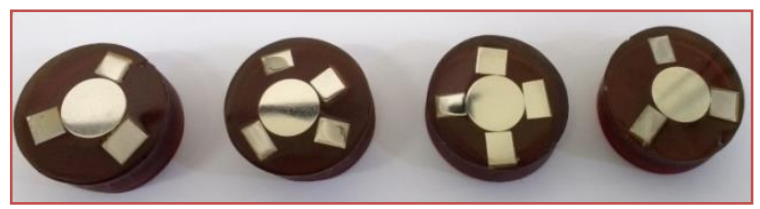

0 lixamento inicia com lixas d'água grão 100, passando sucessivamente pelas lixas grão 220, 320, 400, 600,1500 . Após cada etapa de lixamento, tomou-se cuidado para que os riscos provenientes do lixamento anterior desaparecessem por completo.

Com a troca de cada lixa, é necessário rotacionar a amostra em $90^{\circ}$ na direção do lixamento. Isso facilitou a observação dos riscos provenientes da lixa anterior, e evita que a amostra fique abaulada. Com a finalização do lixamento, foi realizado o polimento da amostra.

Foi utilizado um pano de polimento, com lubrificação constante de pasta de diamante de 0,5 mícron dissolvida em água em uma proporção de $3 \mathrm{ml}$ de pasta de diamante para $200 \mathrm{ml}$ de água. Para melhor acabamento no lixamento, girando a amostra no sentido contrário ao pano de polimento. Esse processo foi feito até que se considerou que a amostra estivesse isenta de riscos, trincas e o mais plana possível.

Para análise metalográfica posterior, foi necessário o ataque eletroquímico com reagentes. 0 ataque eletroquímico com a solução de $60 \%$ de HNO3 (ácido nítrico) e 40\% de H2O (água) além de uma fonte de alimentação 0 a 30 Vcc - 0 a 3 A. Assim foi necessário imergir a amostra na solução e com a passagem de corrente elétrica de um A durante 120 segundos. Após os 120 segundos a amostra foi retirada da solução e banhada em álcool. Para sua limpeza foi necessário um secador e algodão. Após o processo de limpeza pode-se levar a amostra ao microscópio, fig. 6, para verificar a microestrutura resultante. 
Figura 6. Microscópio de análise.

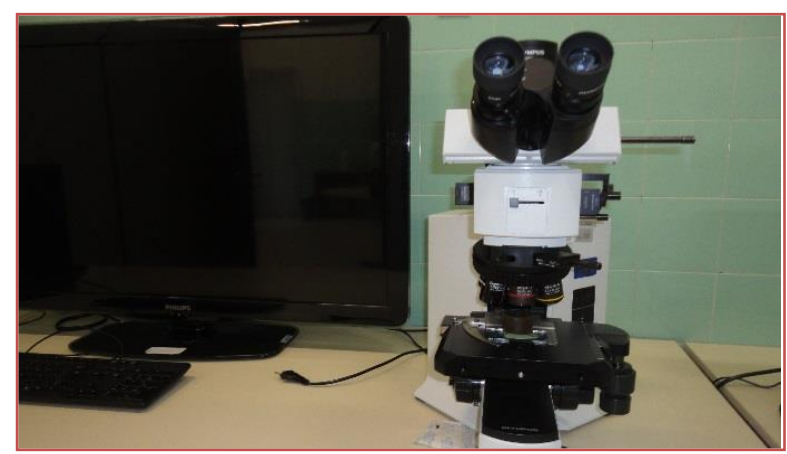

Com a amostra posicionada sobre a lente do microscópio, pode-se verificar a microestrutura resultante do ataque químico. Desta maneira, foi retirada uma imagem de cada material. Após a captura das imagens metalográficas, foram realizados ensaios de microdureza Vickers utilizando uma microdurômetro da marca Shimatzu.

Esse aparelho gera uma impressão em forma de um losango, ao qual deve ser medido com o auxílio de um retículo acoplado ao aparelho. Com a medição das diagonais do losango,que devem ser similares, pode-se definir o resultado da dureza por comparações em tabelas de conversão.

Vale salientar que foram realizados todos os ensaios em cada um dos corpos de prova, ou seja, quatro resultados diferentes.

\section{RESULTADOS}

A ordem de apresentação dos resultados seguirá a mesma ordem cronológica que foram apresentados os métodos e ensaios utilizados.

A tab. I apresenta os resultados da análise química realizada no Spectômetro. Os resultados são apresentados em percentual de massa. É possível perceber que o percentual de Cromo com variação entre $17 \%$ e $18 \%$, assim, pode-se avaliar que o material apresenta uma boa passividade, pois atende as literaturas descritas anteriormente. Pode ser visível pela tabela I, que os materiais denominados com a letra "L", realmente possuem teor de carbono inferior aos demais. Desta forma justificando sua especificação.

Tabela I. Resultados análise química [\% massa].

\begin{tabular}{|c|c|c|c|c|c|c|c|c|}
\hline AISI & $\mathrm{C}$ & $\mathrm{Si}$ & $\mathrm{Mn}$ & $\mathrm{P}$ & $\mathrm{S}$ & $\mathrm{Cr}$ & $\mathrm{Mo}$ & $\mathrm{Ni}$ \\
\hline 304 & 0,130 & 0,64 & 1,36 & 0,04 & 0,01 & 18,4 & 0,18 & 7,93 \\
\hline $304 \mathrm{~L}$ & 0,007 & 0,40 & 2,00 & 0,03 & 0,01 & 18,77 & 0,45 & 8,10 \\
\hline 316 & 0,020 & 0,40 & 1,81 & 0,03 & 0,01 & 17,60 & 1,86 & 9,95 \\
\hline $316 \mathrm{~L}$ & 0,010 & 0,30 & 1,55 & 0,02 & 0,01 & 17,37 & 1,96 & 10,07 \\
\hline
\end{tabular}

Analisando a tabela I, é possível também perceber que o elemento Molibdênio (Mo) é um item determinante na denominação dos aços inoxidáveis, pois enquanto o AISI 304 e 304L possuem teores considerados residuais, os aços AISI 316 e AISI $316 \mathrm{~L}$ possuem valores denominados como elementos de liga, pois estão em teores superiores aos demais aços em estudo.

Quanto os limites de teores dos demais elementos, estes se enquadram dentro das especificações que a norma ASTM determina, sem grandes variações.

Logo após os resultados de composição química foi analisado a metalografia dos materiais. Com o auxílio do microscópio pode-se obter imagens. A fig. 7a e 7b apresentam o material AISI 304L com sua ampliação de $500 \mathrm{X}$, apenas polida e após o ataque eletroquímico respectivamente. Desta forma todas as posteriores 
imagens dos outros materiais serão apresentadas com a mesma ampliação, podendo assim fazer uma análise comparativas dos resultados de microscopia óptica.

Figura 7. Amostra de AISI 304L, (a) apenas polida e (b) atacada quimicamente.

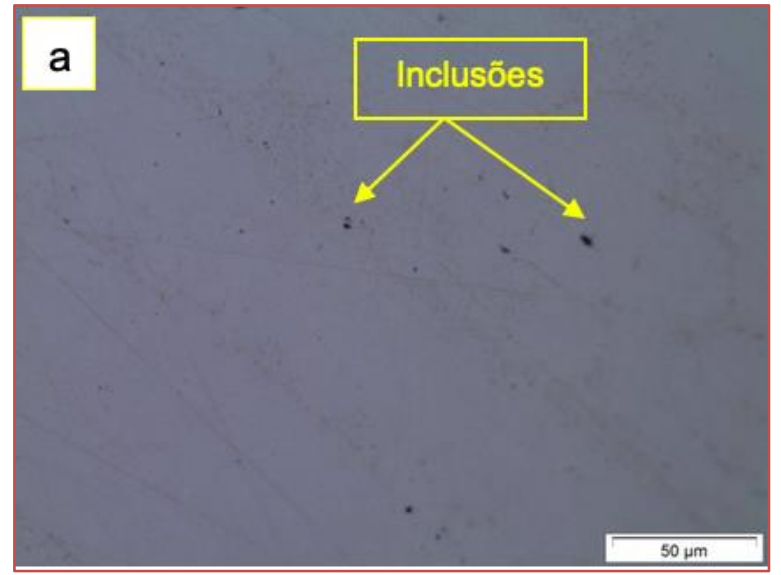

(a)

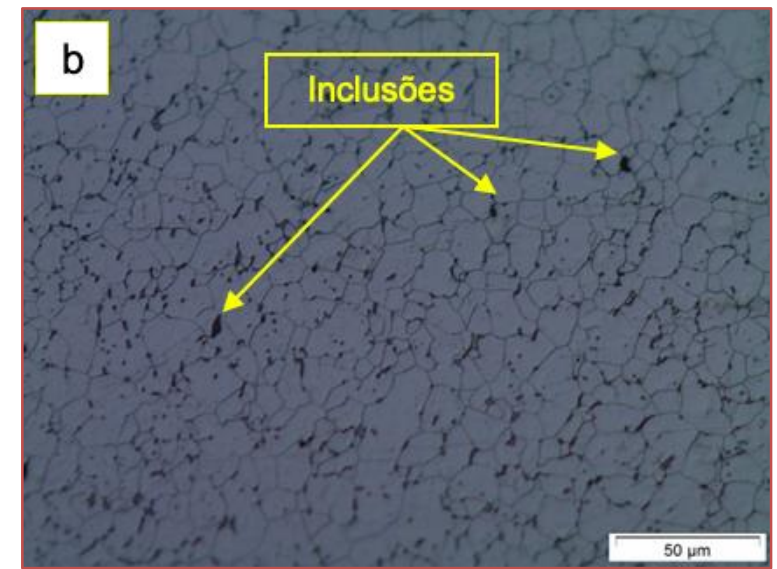

(b)

Na fig. 7 (a) é visível que o material ainda possui pontos, que serão denominados como inclusões, pois dificilmente encontra-se um material totalmente isento de elementos residuais.

A fig. 7 (b) apresenta grãos bem definidos e formação austenítica, tido por base comparações de literaturas de microestruturas, percebe-se também as inclusões no aço(9).

o que determina um grão ser caracterizado como austenítico é seu formato poligonal, e também os tamanhos de grão possuem homogeneidade em toda a imagem apresentada, sendo um reflexo de todo o corpo de prova.

Na fig. 8 (a) e (b), temos o resultado da imagem metalográfica do material AISI 304, novamente antes e após ataque. Tomou-se cuidado para que todas as imagens resultantes da metalografia fossem capturadas com a mesma ampliação, $500 \mathrm{X}$, para possível comparação quanto ao tamanho dos grãos e número de inclusões. Assim, é evidente que o material AISI 304 apresenta tamanho de grão maior que na análise anterior (fig. 7-b). Inclusive este material possui grão em início de difusão com seus grãos vizinhos, ou seja, reduzindo o número de interceptos, mas aumentando o tamanho dos grãos. Com uma comparação sobre impurezas, é percebido a quantidade menor no material AISI 304.

Figura 8. Amostra de AISI 304, (a) apenas polida e (b) atacada quimicamente.

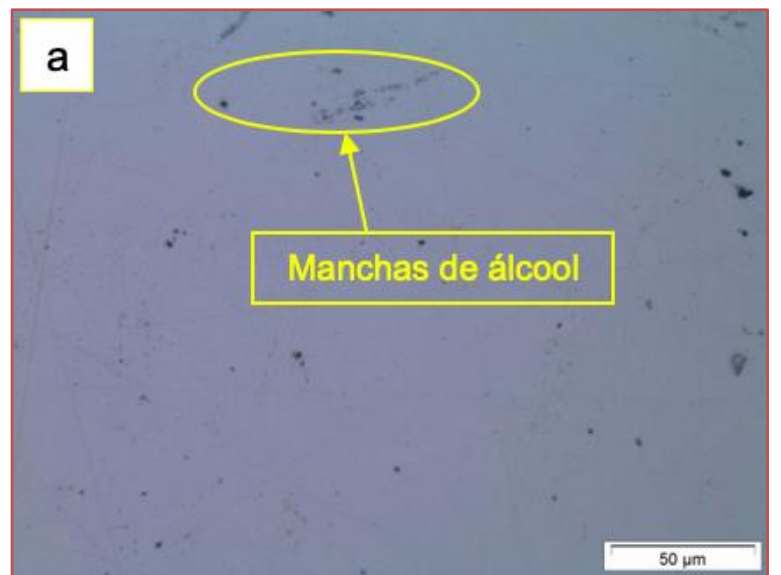

(a)

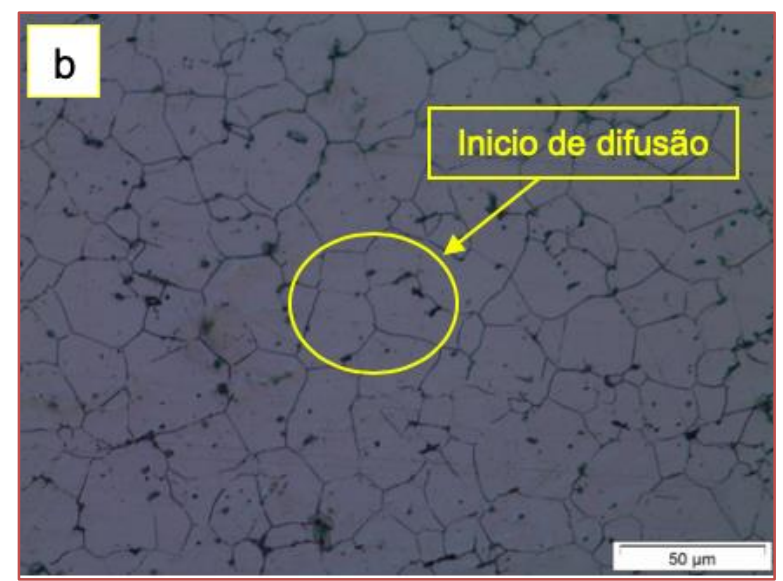

(b) 
Na fig. 8 (a), está representado que durante o processo de limpeza da amostra após o polimento, surgiu manchas proveniente do ato inadequado de secagem da amostra. Para tanto, se fez necessário um novo processo de lavagem e secagem da amostra.

Após a finalização da captura das imagens nos materiais AISI 304 e AISI 304 L, seguiu-se para a análise dos materiais da classe AISI 316. Esses materiais, como já indicado na tab. I, possuem um percentual de cromo (Cr) inferior ao indicado na classe AISI 304, porém, na classe AISI 316 temos a adição de molibdênio (Mo) três a quatro vezes maior.

Figura 9. Imagem microscópica do AISI 316L (a) apenas polida e (b) atacada quimicamente.

(a)

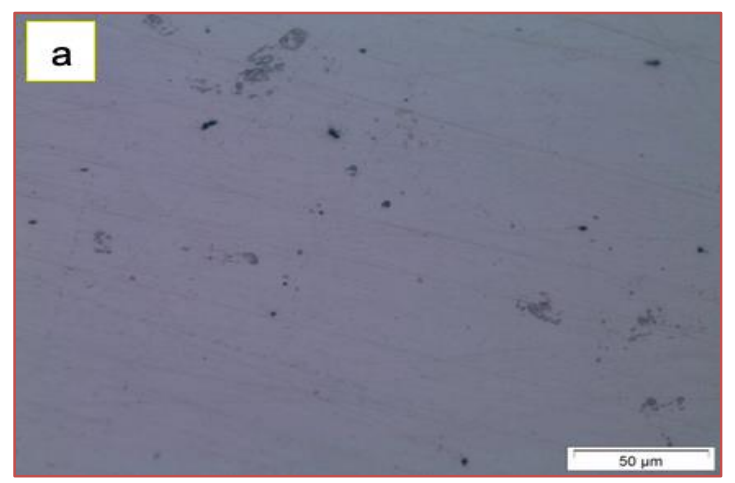

(b)

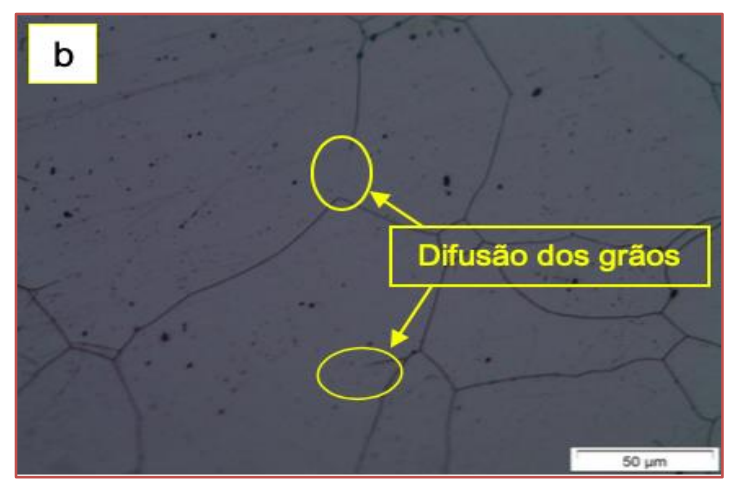

A fig. 9 (a) apresenta a superfície da amostra com indicação de riscos, possivelmente derivados do processo de lixamento e polimento inadequados. Para tanto foi necessário um novo processo de aplicação de lixas a partir do número 400 mesh.

A fig. 9 (b) mostra o aço AISI 316L após ataque eletroquímico, inda sendo possível perceber alguns riscos provenientes do lixamento da amostra.

Pode ser percebido, ainda, pela escala que a captura da imagem foi realizada em mesma ampliação dos materiais anteriores e pode-se destacar o tamanho dos grãos deste material, ao qual encontra-se muito maior do que os materiais já analisados.

Em relação as impurezas (Enxofre e Fósforo), o material AISI 316L pode ser mencionado com menor grau de impurezas, em comparação aos já analisados. Pode enaltecer também que ocorreu o processo de difusão por parte dos grãos maiores em relação aos grãos menores, pois existem contornos de grãos que não completam a circunscrição poligonal já descrita, sendo mencionada na fig. 9 (b).

Para a finalização das análises dos quatro corpos de prova, foi encaminhado a preparação das amostras do material AISI 316. Este material passou pelos mesmos processos de lixamento e polimento até que a sua face se tornasse satisfatória para análise microestrutural, ou seja, brilhante, polida e com o mínimo de marcas.

Figura 10. Amostra de AISI 316 (a) apenas polida e (b) atacada quimicamente.

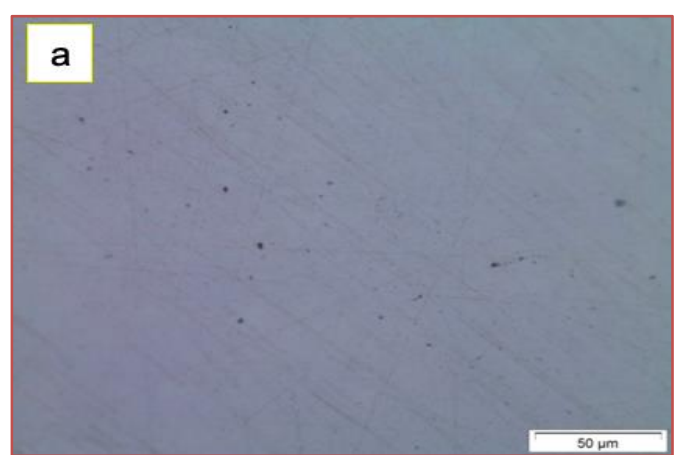

(a)

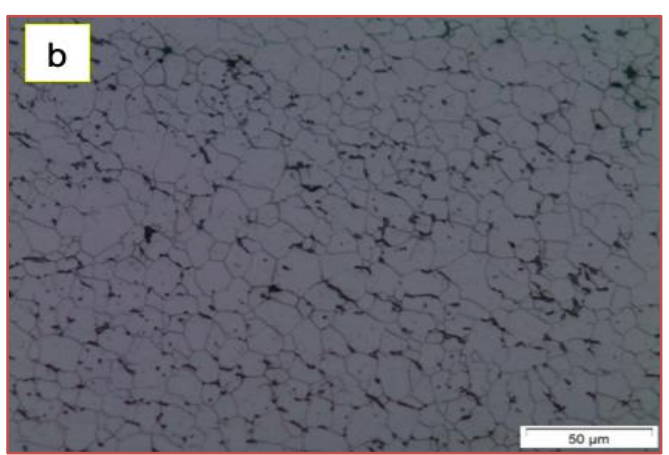

(b) 
As fig. 10 (a) e (b) representam o aço AISI 316, apenas polida e pós-processo de ataque eletroquímico, respectivamente.

Analisando a imagem do material AISI 316, Fig. 10 (b), é visível que o mesmo apresenta tamanho de grãos inferior do demonstrado no material AISI 316 L, porém similar ao AISI 304 L. Esta situação pode ser resultante do tratamento térmico realizado no material ou do processo de trefilação, ao qual não será debatido neste trabalho.

Os resultados dos ensaios de dureza estão presentes na tab. II. Os ensaios de microdureza foram realizados em todas as amostras partindo da extremidade até $0,18 \mathrm{~mm}$ em direção ao centro do corpo de prova. Os resultados de todos os corpos de prova estão na mesma tabela para que possa ser feita uma comparação entre a dureza dos materiais.

Tabela II Resultados dos ensaios de dureza

\begin{tabular}{|l|l|l|l|c|}
\hline \multicolumn{5}{|c|}{ Ensaio de Microdureza HV [0,1] } \\
\hline Dist. [mm] & 316 & $316 \mathrm{~L}$ & 304 & $304 \mathrm{~L}$ \\
\hline 0,02 & 354 & 388 & 443 & 340 \\
\hline 0,06 & 309 & 304 & 350 & 334 \\
\hline 0,10 & 293 & 280 & 324 & 311 \\
\hline 0,14 & 269 & 261 & 319 & 285 \\
\hline 0,18 & 256 & 261 & 287 & 283 \\
\hline
\end{tabular}

Com os resultados apresentados anteriormente de microdureza, pode-se construir o Graf. I, demonstrando o perfil de microdureza de cada material empregado no estudo em questão. Com esse gráfico podemos ver melhor a comparação do comportamento entre os materiais, pois todos foram submetidos aos mesmos parâmetros de usinagem, porém responderam de maneiras diferenciadas.

Gráfico I. Resultado do comportamento da microdureza partindo da extremidade ou centro.

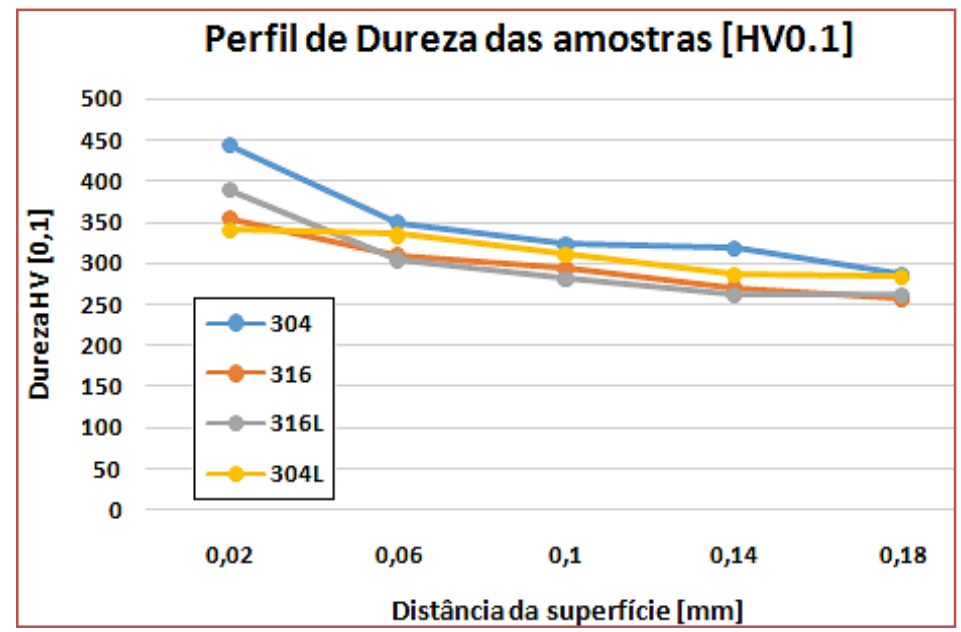

Analisando os resultados encontrados percebe-se que o material AISI 304 apresenta maior dureza na extremidade, chegando a $450 \mathrm{HV}$. Pode-se destacar também que a 0,18 mm todos os materiais apresentam durezas similares. Assim pode-se definir, que de alguma forma, os agentes externos de preparação do corpo de prova afetaram muito mais as durezas nos materiais AISI 304 e AISI 316L. 


\section{CONCLUSÃO}

Após todos os ensaios realizados, finalizados e discutidos, pode-se, com base nas informações também obtidas em literaturas, tomar como conclusões que:

Deve-se tomar muitos cuidados durante a preparação de uma amostra, seja para análise metalográfica, química ou dureza. Caso uma amostra não esteja com as características necessárias para posterior análise, isso poderá levar a uma interpretação errônea, causando complicações na análise final do material.

Dentre os materiais analisados o material com maior dureza encontrada foi o AISI 304 e nas suas extremidades. Isso pode ter ocorrido devido algum superaquecimento por usinagem de desbaste ou corte.

Os materiais com a classe "L" apresentam menor teor de Carbono em relação aos que não são desta classe. Isso pode ser afirmado com base nas análises químicas e também pelos resultados metalográficos onde o número de impurezas e óxidos apresenta-se menor.

O tamanho de grão não pode ser determinado pela composição química dos aços, pois dependem de outros fatores, tipo de tratamento por exemplo, e que não foram objeto de estudo deste trabalho.

Mesmo sendo mencionado que as amostras apresentavam inclusões, para se ter maior certeza deste tipo de inclusão torna-se necessário uma análise química pontual em cada tipo de inclusão.

Os testes realizados são de grande importância nas indústrias metalúrgicas. Informações como as adquiridas neste trabalho, podem garantir maior confiabilidade na utilização de determinada peça com grandes responsabilidades. Os ensaios apresentados, comumente, são realizados em controle de qualidade, porém, poucas pessoas têm os conhecimentos necessários para retirar conclusões que definam a melhor utilização do material.

São necessários cada vez mais trabalhos acadêmicos que visam melhorar a eficiência dos materiais aplicados em estruturas de grande risco. Desta forma todo trabalho que visa aumentar a durabilidade, juntamente com a diminuição de custo é de grande valia.

\section{REFERÊNCIAS}

[1] COLPAERT, Hubertus. Metalografia: Dos produtos siderúrgicos comuns. São Paulo: Editor Edgard Blucher LTDA, 2000.

[2] AMERICAN SOCIETY FOR TESTING AND MATERIALS. ASTM A751 - 11: Standard test methods, practices, and terminology for chemical analysis of steel products. ASTM International.

[3] SPECTRO Princípio de funcionamento de um analisador de metais estacionário.s. Disponível em: representatives. spectro.com. Acesso em: 17/04/2016.

[4] MANNHEIMER, Walter A. et al. Microscopia dos Materiais: Uma introdução. Rio De Janeiro: Sociedade Brasileira de Microscopia e Microanálises, 2002.

[5] Héctor Mario Carbó. Aço Inoxidável: Aplicações e Especificação. 2001. Disponível em: www.nucleoinox.org.br. Acesso em: 17/04/2016.

[6] Regis Almir Rohde. Metalografia Preparação de Amostras. 2010. Disponível em: www.urisan.tche.br. Acesso em: 17/04/2016.

[7] MARTINS, Marcelo ET al. Análise Microestrutural de Aços Inoxidáveis Altamente Ligados: da Amostragem à Interpretação. 2014. Disponível em: www.nucleoinox.org.br. Acesso em: 25/04/2016.

[8] PADILHA, Angelo Fernando; GUEDES, Luis Carlos. Aços inoxidáveis austeníticos: microestrutura e propriedades. São Paulo (SP): Hemus, 1994. 170 p.

[9] METALOGRAFIA: Tamanho de grão ASTM E112. Tamanho de grão ASTM E112. Disponível em: <www.testmat.com.br>. Acesso em: 20 maio 2016.

[10] ASSOCIAÇÃO BRASILEIRA DE NORMAS TECNICAS. ABNT NBR 6507-1: Materiais Metálicos: ensaio de dureza Vickers. 2008 


\section{Capítulo 8}

\section{Caracterização e reciclagem de filmes multicamadas metalizados pós-consumo}

\section{Andrea Bettanin \\ Ruth Marlene Campomanes Santana}

Resumo: Filmes multicamadas metalizados são amplamente utilizados devido às suas ótimas propriedades para conservação de alimentos. Na maioria dos casos, estes são descartados em aterros. Este estudo apresentou como objetivo caracterizar filmes multicamadas metalizados pós-consumo e avaliar o seu desempenho mecânico após reciclagem secundária. As amostras foram recolhidas em containers de resíduos localizados na universidade UFRGS e separadas de acordo com a norma ABNT NBR 13230 em dois grupos: G5 e G0, para embalagens com identificação número cinco, e com ausência de identificação, respectivamente. As análises térmicas de DSC e química por FTIR indicaram que a porção polimérica da amostra G5 é composta por PP e de G0 por PP, PELBD, PEBD e PA-6. 0 grupo G0 atingiu aproximadamente 55\% da resistência ao impacto apresentada pelas amostras do grupo G5. 0 estudo apresentou a importância da identificação e segregação das embalagens pós-consumo para o incremento do desempenho mecânico dos produtos reciclados.

Palavras-chave: embalagens de filmes flexíveis, reciclagem, triagem de resíduos, embalagens pós-consumo. 


\section{INTRODUÇÃO}

"Hoje, a humanidade consome $30 \%$ a mais do que o planeta pode naturalmente repor". Transformações, portanto, se fazem necessárias, e o mercado da reciclagem opera como possível termômetro dessas mudanças ( Dentro desta problemática, surgem também as embalagens plásticas, presentes em diversos setores, dentre eles, da indústria alimentícia. Estes materiais têm como principal função conservar o alimento por meio de propriedades de barreira aos fatores ambientais como luz, umidade, oxigênio e microrganismos (

Filmes poliméricos, como BOPP - polipropileno biorientado, apresentam boas propriedades mecânicas e de barreira a gases e a umidade e, portanto, são excelentes opções para conferir propriedades de barreira com espessura total reduzida ( Uma barreira adicional tradicional tem sido o alumínio, primeiramente na forma de lâmina na ordem de alguns micrômetros (filmes laminados), e, mais recentemente, como um revestimento através de deposição a vácuo (metalização) com uma espessura na faixa de alguns nanômetros. Os filmes laminados de alumínio fornecem uma barreira virtualmente total, enquanto que camadas metalizadas podem fornecer barreiras quase tão eficientes a um valor mais baixo. Os polímeros tipicamente aplicados em embalagens alimentícias são a base de poliamida, como poli-' $\varepsilon$ '-caprolamida (PA-6 ou náilon-6), BOPP, polietileno de baixa densidade (PEBD), polietileno linear de baixa densidade (PELBD) ou poliéster, como politereftalato de etileno (PET) ( A combinação das boas propriedades mecânicas e baixa absorção de água do PELBD com à maior facilidade de processamento do PEBD faz com que estes sejam comumente empregados como blendas de PELBD/PEBD aplicados como filmes poliméricos para embalagens (

Apesar da mistura de diferentes materiais em uma única embalagem melhorar suas propriedades requeridas para a conservação de produtos, este procedimento dificulta sua reciclagem ( A reciclagem da fração seca reciclável é comumente atribuída somente aos plásticos rígidos, muitas vezes sendo descartada a possibilidade da recuperação dos polímeros flexíveis ( Segundo laudo realizado pelo CETEA, Centro de Tecnologia de Embalagem, dentre 19 das 196 empresas recicladoras de PP no Estado de São Paulo, apenas duas destas reciclam filmes de BOPP, sendo que somente uma recicla BOPP metalizado, e ambas trabalham exclusivamente com resíduos de origem industrial ( Em Porto Alegre (RS), Brasil, de seis Unidades de Triagem entrevistadas todas afirmaram não possuírem compradores para as embalagens de filmes metalizados. Não ocorrendo a reciclagem destes produtos, estes acabam sendo destinados a aterros sanitários junto a outros resíduos incapazes de reciclagem (

A norma ABNT NBR 13230 - "Embalagens e acondicionamentos plásticos recicláveis - identificação e simbologia" trata do método de identificação de embalagens no Brasil a qual visa facilitar a reciclagem de resinas termoplásticas ( No entanto, Coltro e Duarte (2013) mostraram que cerca de metade das embalagens plásticas flexíveis avaliadas não apresentavam a identificação do plástico utilizado em sua composição, e em alguns casos cerca de $30 \%$ das embalagens apresentaram a identificação de forma incorreta

0 presente trabalho apresentou como objetivo caracterizar os diferentes filmes multicamadas metalizados pós-consumo, tendo em vista facilitar possíveis processos de reciclagem futuros.

\section{MATERIAIS E MÉTODOS}

\subsection{MATERIAIS}

Para a realização do presente trabalho, amostras de filmes multicamadas metalizadas/laminadas provenientes de embalagens de alimentos foram coletadas em containers de resíduos localizados na Universidade Federal do Rio Grande do Sul (UFRGS). A separação destas foi realizada com base na identificação das embalagens estabelecidas pela norma ABNT NBR 13230 (1994) ( Dois grupos distintos foram estabelecidos: G5 e G0, para embalagens com identificação de reciclagem número cinco, referente ao PP, e produtos com ausência de identificação, respectivamente, como mostrado na Figura 1. 
Figura 1 - Imagens de exemplos de embalagens de filmes multicamadas metalizados utilizados no estudo. Amostras a) e b) com o símbolo de reciclagem número 5, e amostra c) sem qualquer identificação de material na embalagem. 0 nome e marca do produto foram ocultadas.

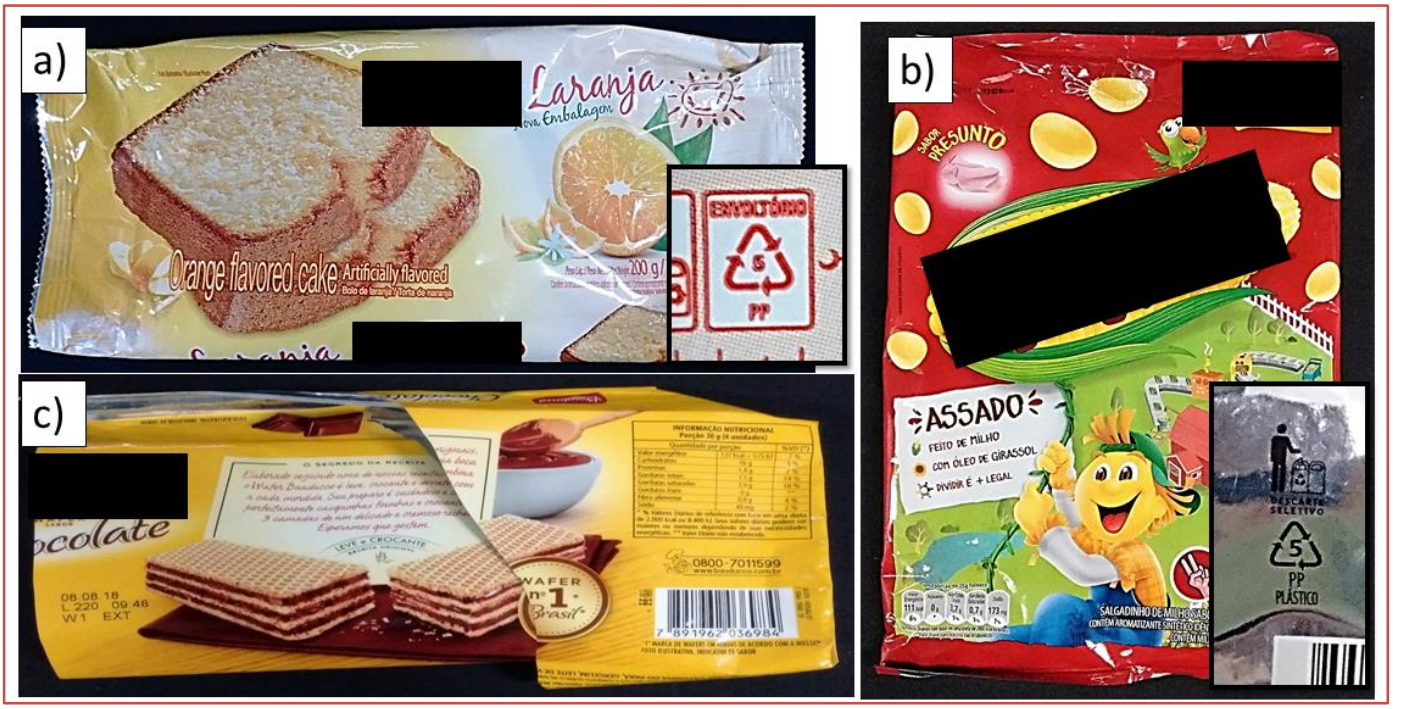

\subsection{METODOLOGIA}

Após, os grupos passaram separadamente por processo de prensagem em prensa hidráulica Solab SL11 por 15 minutos a $190^{\circ} \mathrm{C}$ e pressão de 5 bar, com pré-aquecimento de 4 minutos. A moagem em moinho de facas da marca Retsch, modelo SM2000, foi realizada utilizando-se aberturas de $10 \mathrm{~mm}$ e $4 \mathrm{~mm}$. Parte das amostras cominuídas foram processadas em câmara de mistura DVE- HAAKE Rheodrive 7, na temperatura de $270^{\circ} \mathrm{C}$, velocidade de $60 \mathrm{~Hz}$ e tempo de cinco minutos. Os corpos de prova foram moldados em uma mini-injetora da marca Thermo Scientific, modelo Minijet II. Os parâmetros utilizados foram temperatura de aquecimento de $200^{\circ} \mathrm{C}$ por 2 minutos e temperatura do molde de $50^{\circ} \mathrm{C}$ por 1 minuto, pressão de injeção e de recalque, por 10 segundos, de 470 bar e 350 bar, respectivamente.

\subsection{CARACTERIZAÇÃo}

As amostras foram caracterizadas por análises térmicas, mecânicas, químicas e físicas. A análise de termogravimetria (TGA) foi realizada em analisador termogravimétrico TA Instruments, modelo Q50, com taxa e rampa de aquecimento de $20^{\circ} \mathrm{C} / \mathrm{min}$ e de temperatura ambiente até $900 \mathrm{oC}$ respectivamente em atmosfera de N2. Para identificação dos materiais poliméricos foi usado as técnicas de calorimetria diferencial de varredura, DSC da TA Instruments, modelo Q20, em atmosfera de $\mathrm{N} 2$, na taxa de $10^{\circ} \mathrm{C} / \mathrm{min}$, em ciclos de aquecimento, resfriamento e segundo aquecimento; e por análise química por infravermelho com espectrofotômetro FTIR Perkin Elmer modelo Spectrum 1000, na faixa de $4000 \mathrm{~cm}-1$ a $400 \mathrm{~cm}-1$.

Os ensaios de índice de fluidez foram conduzidos segundo a norma ASTM D1238, em equipamento plastômetro de extrusão da marca Ceast, em temperatura de aquecimento de $230{ }^{\circ} \mathrm{C}, 2,16 \mathrm{Kg}$ e tempo de $240 \mathrm{~s}$, com $4 \mathrm{~g}$ de amostra, e tempo de corte de 10 segundos.

O equipamento de Impacto Izod Ceast Impactor II foi utilizado com martelo de 2,75J, em amostras sem entalhe, para a caracterização de desempenho mecânico das amostras.

\section{RESULTADOS E DISCUSSÃO}

Na Figura 2 são mostradas as curvas térmicas obtidas por DSC das amostras G0 e G5 no segundo aquecimento. As análises de calorimetria diferencial de varredura indicaram uma variação na composição polimérica entre as amostras G0 e G5. É possível observar a presença de quatro picos distintos na curva referente à amostra G0, nas temperaturas de $108^{\circ} \mathrm{C}, 120^{\circ} \mathrm{C}, 159^{\circ} \mathrm{C}$ e $228^{\circ} \mathrm{C} .0$ aparecimento de dois picos endotérmicos próximos à faixa de temperatura de $105-110^{\circ} \mathrm{C}$ e $121-125^{\circ} \mathrm{C}$ são associados à presença de polietileno linear de baixa densidade (PELBD). 0 pico referente ao polietileno de baixa densidade se sobrepõe a esta faixa, estando entre 105 e $115^{\circ} \mathrm{C}$ ( De acordo com Canevarolo (2003), o pico referente ao 
polipropileno com alto grau de cristalinidade encontra-se na faixa entre 160 a $165^{\circ} \mathrm{C}$, identificado nas curvas de DSC de ambas as amostras, G0 e G5 ( Em conjunto com estudo bibliográfico, o pico na temperatura de $228,3^{\circ} \mathrm{C}$ na amostra G0 pode ser atribuído à presença de PA-6 ( Já para a amostra G5, apenas um pico, na temperatura de $160^{\circ} \mathrm{C}$ foi identificado, referente, conforme já discutido, à presença de polipropileno.

Figura 2 - Curvas de DSC das amostras G0 e G5.

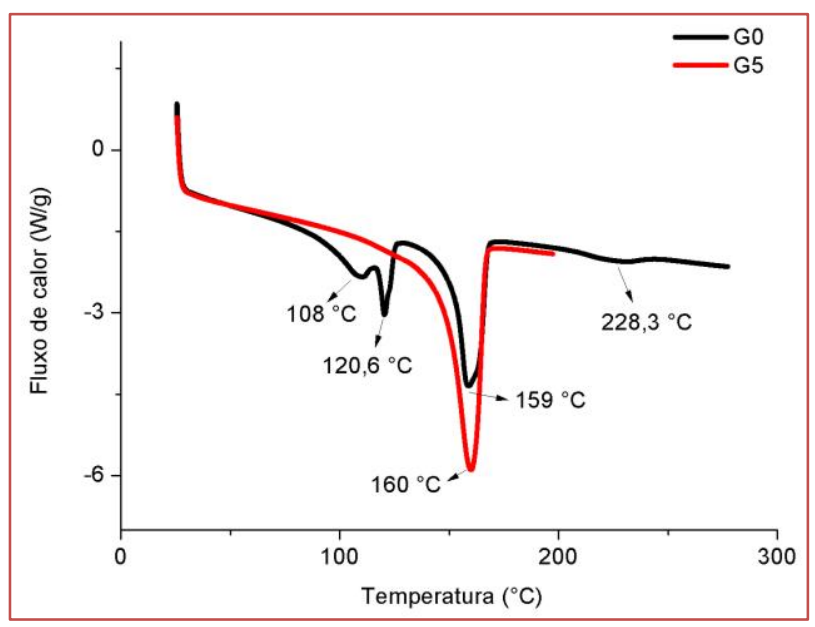

Os termogramas das amostras G0 e G5 obtidos pela análise termogravimétrica são apresentados na Figura 3. É possível observar um comportamento semelhante quanto à perda de massa das amostras com o aumento de temperatura. No entanto, uma variação nos resultados, mostrados na Tabela 1, pode ser conferida à diferença da composição das amostras. Os valores mais elevados de temperatura nas perdas de massa em 5 e 10\%, e de temperatura de pirólise indicada por DTG das amostras G0 podem ser atribuídas à presença de PA-6 na composição dessas amostras, o qual possui uma temperatura de fusão maior do que os outros polímeros presentes na amostra. Após a temperatura do pico de taxa de perda de massa das amostras, foi identificada a variação de massa da porção não referente à matriz, provavelmente referente à presença de tintas e adesivos presentes nas embalagens. Em embalagens de alimentos de filmes flexíveis, espera-se a presença de alumínio (camada laminada ou metalizada) e possivelmente compostos inorgânicos como Ti02, CaCO3 e ZnO aplicados pigmentos em tintas ( A porção de resíduo apresentada na análise termogravimétrica pode ser referente a estes compostos. No entanto, não foram realizadas análises químicas destes elementos para a confirmação desta hipótese.

Figura 3 -Termogramas de a) TGA e b) DTG obtidas das amostras G0 e G5.

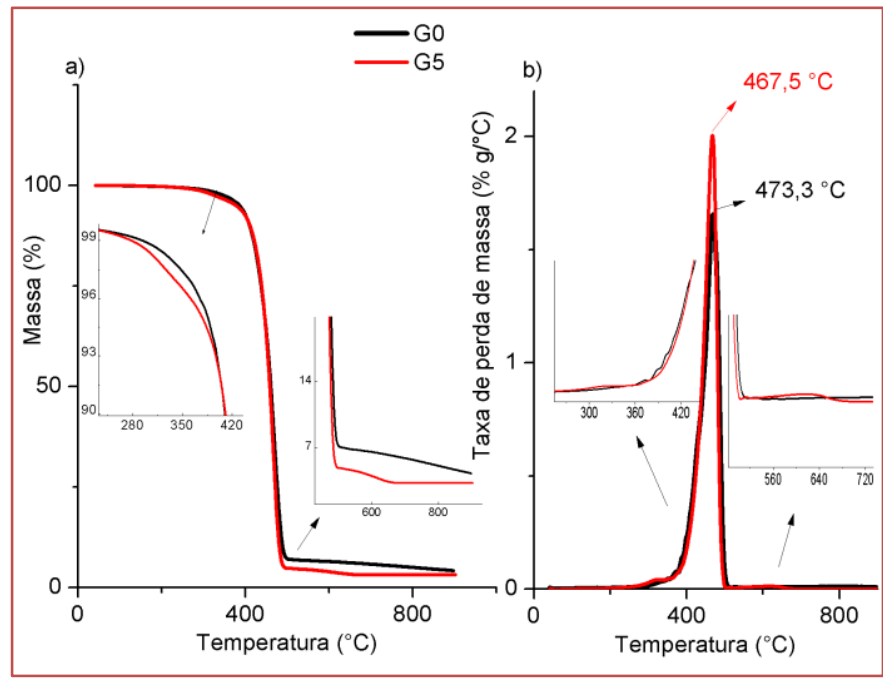


Tabela 1 - Resultados obtidos a partir da análise de TGA das amostras G0 e G5.

\begin{tabular}{|c|c|c|c|c|c|c|}
\hline Amostra & $\begin{array}{l}\text { T } 5 \% \\
\left({ }^{\circ} \mathrm{C}\right)\end{array}$ & $\mathrm{T} 10 \%\left({ }^{\circ} \mathrm{C}\right)$ & $\begin{array}{c}\text { Matriz polimérica } \\
(\%)\end{array}$ & $\begin{array}{c}\text { Não-matriz } \\
\text { polimérica (\%) }\end{array}$ & $\begin{array}{l}\text { Resíduo } \\
(\%)\end{array}$ & $\begin{array}{l}\text { DTG Tp } \\
\left({ }^{\circ} \mathrm{C}\right)\end{array}$ \\
\hline G0 & 391 & 414 & 93,10 & 2,66 & 4,24 & 473 \\
\hline G5 & 379 & 411 & 95,24 & 1,54 & 3,22 & 467 \\
\hline
\end{tabular}

É possível observar uma etapa predominante na curva de TGA para ambas as amostras. Segundo curva de DTG, o pico refere-se às temperaturas de pirólise $467,5{ }^{\circ} \mathrm{C}$ e $473,3{ }^{\circ} \mathrm{C}$ para amostras G5 e G0, respectivamente. Para a amostra G5, mais duas etapas podem ser observadas, em torno de $320^{\circ} \mathrm{C} \mathrm{e} 600^{\circ} \mathrm{C}$. Para a amostra G0 ainda é possível observar alguns pequenos picos a temperaturas mais baixas à principal temperatura de pirólise. A presença destas etapas pode ser atribuída à presença de polímeros comumente utilizados como adesivos, aditivos e/ou resinas, os quais podem iniciar sua degradação a diferentes temperaturas, de acordo com sua composição. Além disso, é importante ressaltar a existência de uma ampla variedade de fabricantes, e, consequentemente, de processes de fabricação das embalagens utilizadas para o estudo, e, portanto, a identificação com exatidão da quantidade e composição dos aditivos utilizados no processo torna-se complexa.

Para complementar informações sobre a natureza da composição química das amostras a Figura 4 apresenta os espectros de FTIR das amostras G0 e G5.

Figura 4 - Curvas de FTIR das amostras G0 e G5.

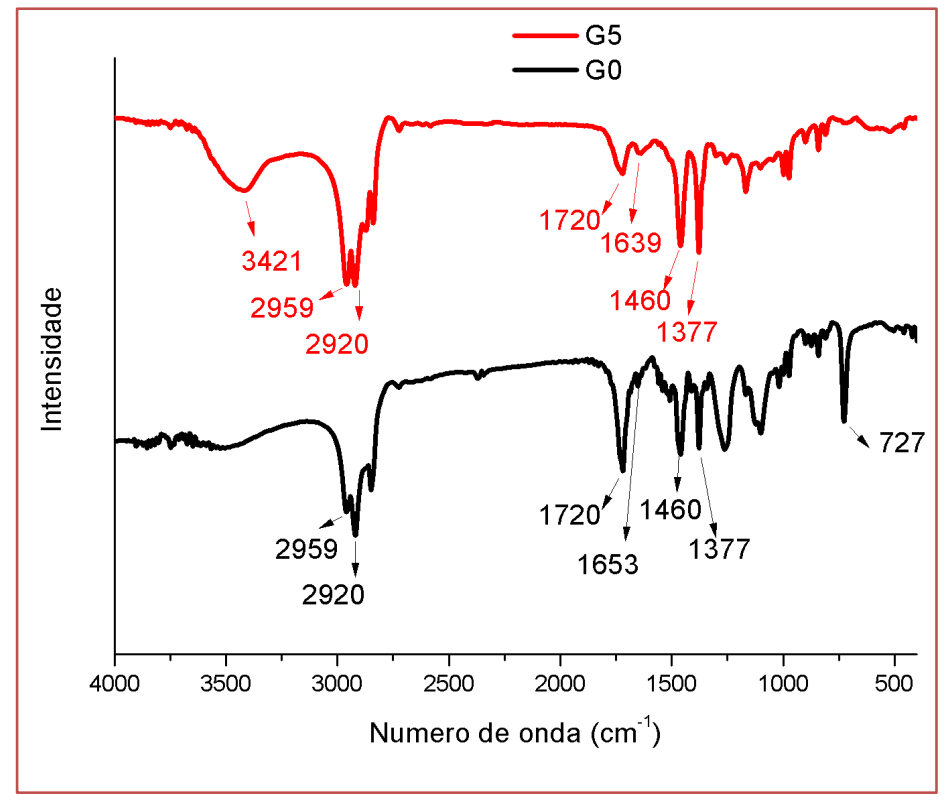

É possível observar picos referentes ao mesmo número de onda em ambas amostras. Picos entre $2960 \mathrm{~cm}$ 1 e $2850 \mathrm{~cm}-1$ são comumente atribuídos à presença de ligações $\mathrm{C}-\mathrm{H}$ alifáticos de carbonos primários e secundários, predominante em PEBD, PELBD e PP. 0 pico $1377 \mathrm{~cm}-1$ pode ser observado devido à deformação angular de grupos metil, contidos em PP. O pico em $1460 \mathrm{~cm}-1$ pode ser atribuído à deformação angular de ligações (CH2), o qual, no caso de sequências longas, também aparece uma banda em torno de $727 \mathrm{~cm}-1$. Neste caso, este pico é observado apenas na amostra G0, devido à provável presença de polietileno e poliamida 6.0 pico $1653 \mathrm{~cm}-1$, presente na amostra G0 é comum de ligações C=0 de amidas, como no caso de PA-6. Segundo Longo et al (2011), os picos $1720 \mathrm{~cm}-1$ e $1640 \mathrm{~cm}-1$ são indícios de grupos carboxílicos de éster, aldeído ou cetonas, e ligações duplas, respectivamente ( De acordo com Arkatkar et al. (2010), a formação destes grupos sugerem a oxidação do polímeroO pico em torno de $3420 \mathrm{~cm}-1$ presente em maior intensidade na amostra G5, assim como em $1720 \mathrm{~cm}-1$ também pode ser atribuída à degradação do $\mathrm{PP}$ com formação de ligações $\mathrm{O}-\mathrm{H}$ e carbonila $\mathrm{C}=\mathrm{O}$ na cadeia polimérica, assim como da presença de possíveis resinas e adesivos. Conforme mencionado 
anteriormente, as amostras foram previamente processadas à $270{ }^{\circ} \mathrm{C}$, temperatura significativamente maior à recomendada para processamento de polímeros como polipropileno, o que pode ter proporcionado a degradação deste.

É comumente relatado que com a degradação do polímero ocorre o aumento do seu índice de fluidez. A partir disso, para identificar a possível degradação da amostra, foi realizado um ensaio de índice de fluidez com o grupo G5. A Tabela 2 mostra os resultados obtidos. Os valores mostram valores de índice de fluidez da amostra pós-reprocessamento em câmara de mistura (identificada por G5_H) mais de 3 vezes superiores à amostra sem processamento (identificada por G5_n-H) resultado que indica a possível degradação da amostra analisada por FTIR.

Tabela 2 - Índice de fluidez da amostra G5 processada na câmara de mistura e pré-processamento amostras G5H e G5_n-H, respectivamente.

\begin{tabular}{|c|c|}
\hline Amostra & Índice de fluidez (g/10min) \\
\hline G5_H & $14,3 \pm 0,8$ \\
\hline G5_n-H & $4,6 \pm 0,2$ \\
\hline
\end{tabular}

A Figura 5 apresenta os resultados de desempenho mecânico das amostras G0 e G5 frente aos ensaios de impacto Izod. É possível observar que a amostra G0 apresentou um comportamento significativamente inferior à amostra G5, chegando a uma média de 55\% da resistência ao impacto do grupo de amostras compostos por PP. Devido à degradação das amostras a temperaturas próximas a $270^{\circ} \mathrm{C}$, o processamento por injeção dos corpos de prova foi realizado a uma temperatura inferior, determinada em $200^{\circ} \mathrm{C}$. Esta temperatura, no entanto, em conformidade com a análise de DSC, não é suficiente para fundir uma fração da amostra do grupo G0. Desta forma, foi possível verificar regiões onde não ocorreu a fusão da embalagem, mostrados na Figura 6.

Figura 5 - Resultados de resistência ao impacto das amostras G0 e G5.

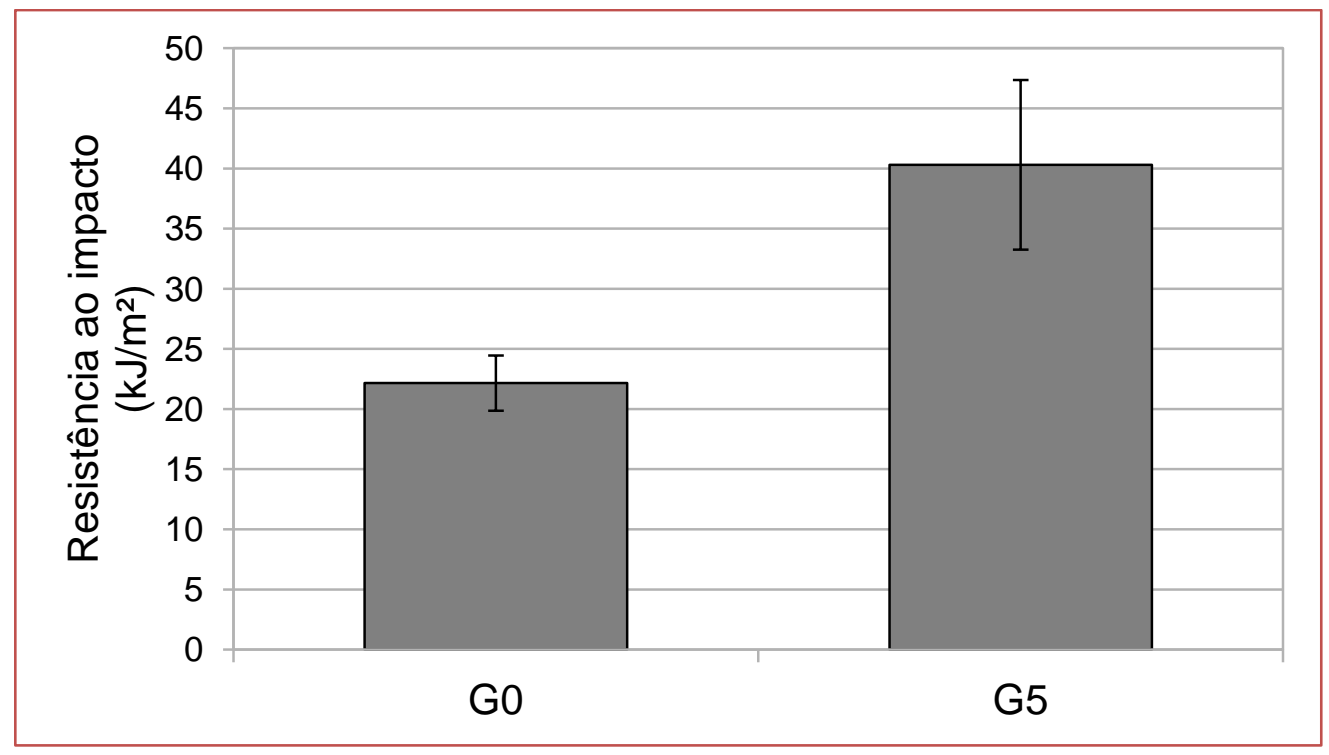

A Figura 6 apresenta os corpos de prova do grupo G0 e G5 após o ensaio de impacto. A seção transversal, revelada por microscopia óptica, apresenta pontos onde não ocorre a fusão de fragmentos de filmes poliméricos (indicados por círculos na imagem). Estes pontos podem ter acarretado em pontos de tensão e superfícies de fraca adesão entre polímeros, os quais podem ter sido determinantes no comprometimento do desempenho das amostras G0 frente aos ensaios de impacto. 
Figura 6 - Imagens de: a) corpos de prova do grupo G0 e G5 após ensaio de impacto. A seção transversal ressaltada pelo retângulo na imagem é revelada por microscopia óptica nas imagens: b) G0 e c) G5.

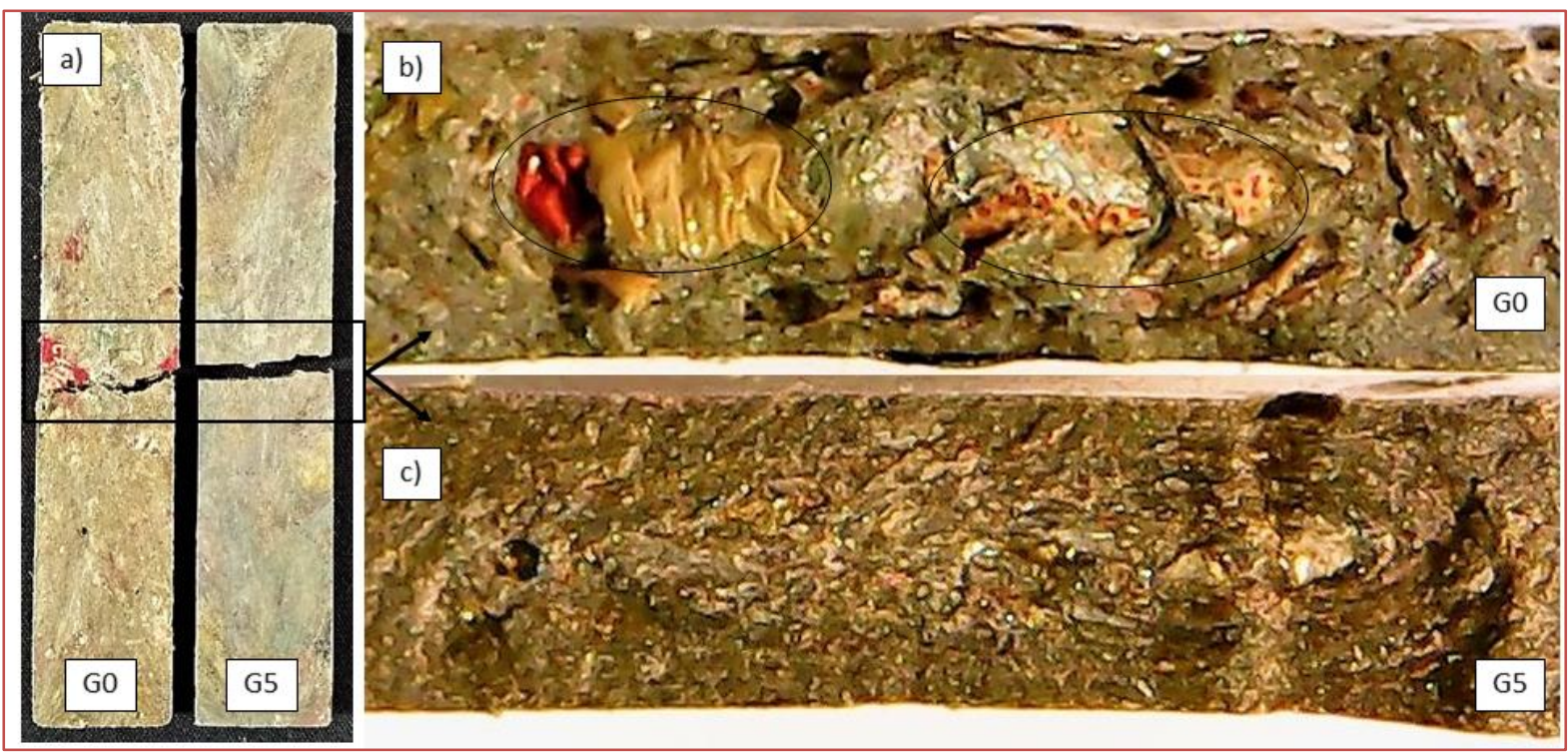

\section{CONCLUSÃO}

As análises de caracterização física e química indicaram que a porção polimérica da amostra G5 é composta majoritariamente por polipropileno. Já para a amostra G0 as análises indicaram uma mistura de PP, PELBD, PEBD e PA-6. A presença de diferentes polímeros na mesma amostra acarretou na degradação desta quando processada a temperaturas necessárias para fundir todo o conteúdo polimérico. Resultados das análises por FTIR e ensaio de índice de fluidez indicaram a ocorrência de degradação da amostra de PP. A partir disso, utilizou-se os mesmos parâmetros de processamento por injeção para G5 e G0. Os resultados do ensaio de impacto indicaram que o grupo de embalagens G0, composta por diferentes materiais poliméricos, atinge aproximadamente $55 \%$ da resistência ao impacto apresentada pelas amostras identificadas como G5. Desta forma, o estudo apresentou a importância da identificação e segregação das embalagens pós-consumo que podem ser aplicadas em unidades de triagem para o incremento do desempenho dos produtos reciclados.

\section{AGRADECIMENTOS}

As autoras agradecem o Laboratório de Materiais Poliméricos (LAPOL) da Universidade Federal do Rio Grande do Sul (UFRGS), CAPES pelo suporte financeiro para que este trabalho pudesse ser realizado, e à Giovana Barbosa por todo auxílio ao longo do presente estudo.

\section{REFERÊNCIAS}

[1] Sarantópoulos, C. I. G. L., de Oliveira, L. M., Padula, M., Coltro, L. \& Alves, R. M. V. Embalagens plásticas flexíveis: principais polímeros e avaliação de propriedades. (CETEA/ITAL, 2002).

[2] Oliveira, L. M., Sarantópoulos, C. I., Teixeira, F. G. \& Suguiuti, P. A. Determinação da força de adesão da metalização com alumínio em filmes plásticos utilizados em embalagens flexíveis-Desenvolvimento e Validação de Metodologia. Polímeros 21, 233-239 (2011).

[3] Lange, J. \& Wyser, Y. Recent Innovations in Barrier Technologies for Plastic Packaging - a Review. Packaging Technology and Science 16, 149-158 (2003).

[4] Goydan, R., Carrol, T. R. \& Schwope, A. D. Evaluation of Polyester and Metallized-Polyethylene Films for Chemical Protective Clothing Applications. Plastic Film \& Sheeting 6, 106-111 (1990).

[5] Baschek, G., Hartwig, G. \& Zahradnik, F. Effect of water absorption in polymers at low and high temperatures. Polymer 40, 3433-3441 (1999).

[6] Clark, J. N., Jagannathan, N. R. \& Herring, F. G. A nuclear magnetic resonance study of poly (aryl ether ether ketone). Polymer 29, 341-345 (1988). 
[7] Pedrag, M. \& Bhattacharya, S. N. Rheology of LLDPE, LDPE and LLDPE/LDPE blends and its relevance to the film blowing process. Polymer International 49, 1580-1589 (2000).

[8] Mark. E., J. Polymer Data Handbook. (Oxford University Press, 1999).

[9] ABRE, A. B. de E. Estudo macroeconômico da embalagem. (2014).

[10] CEMPRE. Cempre Review 2015. (2015).

[11] CETEA/ITAL, C. de T. de E. Simbologia de reciclagem para laminados de BOPP. (2009).

[12] Albuquerque e Souza de Oliveira, A. O Design como ferramenta de tecnologia social: equipamento de processamento de resíduos. (UFRGS, 2015).

[13] Associação Brasileira de Normas Técnicas - ABNT. NBR 13230: Embalagens e acondicionamentos plásticos recicláveis - identificação e simbologia". (2008).

[14] Coltro, L. \& Duarte, L. C. Reciclagem de embalagens plásticas flexíveis: contribuição da identificação correta. Polímeros: Ciência e Tecnologia 23, (2013).

[15] Canevarolo, S. V. Técnicas de Caracterização de Polímeros. (Artliber Editora, 2003).

[16] Adams, L. K., Lyon, D. Y. \& Alvarez, P. J. J. Comparative eco-toxicity of nanoscale TiO2, SiO2, and ZnO water suspensions. Water Research 40, 3527-3532 (2006).

[17] Longo, C., Savaris, M., Zeni, M., Brandalise, R. N. \& Grisa, A. M. C. Degradation study of polypropylene (PP) and bioriented polypropylene (BOPP) in the environment. Materials Research 14, 442-448 (2011).

[18] Arkatkar, A., Juwarkar, A. A., Bhaduri, S., Uppara, P. V. \& Doble, M. Growth of Pseudomonas and Bacillus biofilms on pretreated polypropylene surface. International Biodeterioration \& Biodegradation 64, 530-536 (2010). 


\section{Capítulo 9}

Influência da concentração de refinador de grãos na liga de alumínio fundida A356

\section{Lucas Carvalho Cruz}

Reinaldo de Almeida Rodrigues

Jonathas Santos Morais

Waldeir Santos Dias

Josiel Bruno de Oliveira

Dayane Izabelita Santos Lacerda

José Costa de Macêdo Neto

Resumo: As propriedades mecânicas de produtos produzidos em alumínio no Polo Industrial de Manaus (PIM) estão associadas com o tamanho dos grãos e com o espaçamento dendrítico que são afetados pela formação dos grãos durante o processo de solidificação e tratamento térmico. A adição de refinadores de grãos à liga fundida proporciona a formação de pontos de nucleação durante o processo de solidificação, de forma a se obter uma microestrutura que eleva a elasticidade do alumínio fundido. Neste estudo de caso foi utilizado a liga de alumínio (A356) e realizado a variação nas concentrações do refinador de grãos (TiBAl) nas proporções 0,06\%, 0,08\%, para a fundição em molde permanente. Afim de se avaliar as interações entre a concentração de refinador de grãos e as propriedades mecânica e microestrutural foram realizados os ensaios mecânicos de tração e microscopia óptica de modo a identificar a influência de cada concentração no alumínio fundido.

Palavras-chave: Alumínio, Refino de grão, Nucleante, Fundição, TiBAl3. 


\section{INTRODUÇÃO}

O alumínio é muito utilizado na indústria automobilística e aeroespacial assim como em outras áreas tecnológicas porque possui condutividade elétrica e térmica elevadas, e uma resistência à corrosão em alguns ambientes comuns, como a atmosfera ambiente, além do fato de possuir propriedades mecânicas desejáveis para a produção de produtos com baixo custo a peças com alta complexidade dimensional (Neto, et. al. 2015; Oliveira; Rocha, 2014).

O processo de fabricação do alumínio por fundição envolve a adição de refinadores em ligas de alumínio é uma prática comum em muitas fundições, havendo casos de fundições que realizam a adição de nucleantes em toda e qualquer produção (Chen; Fortier, 2010; Da Silva, 2016).

0 refino de grão por tratamento químico com refinadores de grão não possui o mesmo efeito de um resfriamento rápido relacionando-se com as propriedades mecânicas, porém reduz a tendência de formação de trincas de contração e dispersa a porosidade (Gruzleski, 1990).

A interação entre o titânio e o alumínio para formação do intermetálico TiAl3 permite a formulação da teoria do peritético A reação peritética ocorre a $665^{\circ} \mathrm{C}$ em ligas de alumínio contendo $0,15-1,15 \%$ de titânio, do seguinte modo:

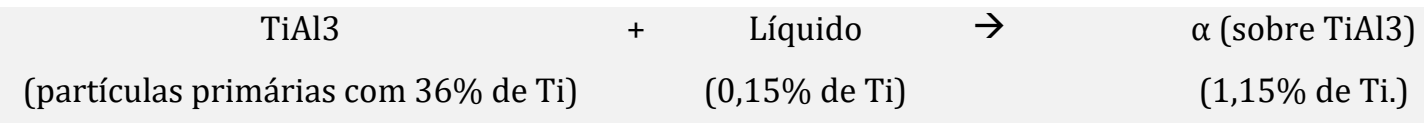

Em condições práticas a fase primária TiAl3 pode se desintegrar parcialmente em cristais muito finos sobre os quais precipita a fase $\alpha$. Estes cristais finos recobertos com a fase $\alpha$ são ideais para a solidificação subsequente, uma vez que se trata de alumínio ( $\alpha$ ) nucleando o alumínio. (Cupini, 1978).

0 tratamento térmico na liga A356 é essencial para o aumento da resistência mecânica após o processo de fundição, a microestrutura tem um papel fundamental para elevar essas propriedades, assim como a distribuição das partículas de Si eutéticas. (Segundo, 2015). 0 endurecimento por precipitação (T6) se dá através do envelhecimento artificial na qual se baseia na formação de um componente intermetálico durante a decomposição da solução sólida supersaturada metaestável formada no tratamento de solubilização. (LI et. al., 2004; Smith, 1998). 0 tratamento térmico de endurecimento por precipitação envolve três fases ilustrados na fig. 1: A solubilização, têmpera e envelhecimento artificial. 0 tratamento térmico de solubilização tem o objetivo de solubilizar os elementos que estão presentes na composição da liga e a dissociação da estrutura do silício e esferoidização das partículas resultantes, ou seja, ocorre a dissolução das fases intermetálicas e a formação de uma solução sólida de elementos responsáveis pelo endurecimento. A amostra que passa pelo tratamento de solubilização é aquecida até a temperatura T0 e mantida até que toda a sua fase $\beta$ tenha sido dissolvida, nesse ponto a liga consiste apenas em uma fase $\alpha$, esse procedimento é seguido pelo resfriamento rápido ou têmpera até alcançar a temperatura T1. A têmpera tem por objetivo arrefecer a amostra até a à temperatura ambiente, esse resfriamento rápido impede a difusão dos elementos que foram dissolvidos na solubilização, formando uma solução sólida supersaturada, de forma a impedir qualquer formação da fase $\beta$ novamente, nesse sentido a peça é mole e fraca pois possui uma estrutura com ausência de equilíbrio. 0 tratamento térmico de precipitação ocorre quando a peça é aquecida até uma temperatura intermediária T2, localizada em uma região bifásica $\alpha+\beta$ onde as taxas de difusão se tornam apreciáveis, a fase $\beta$ precipitada se forma a partir de partículas finas e dispersas que são responsáveis pelo aumento da resistência e dureza num processo conhecido como "envelhecimento", após o envelhecimento apropriado à temperatura T2 a liga é resfriada até temperatura ambiente (Callister, 2012; Moreira, 2011; Furlan, 2008). 
Figura 1. Gráfico esquemático da temperatura em função do tempo, mostrando os tratamentos térmicos de solubilização e envelhecimento artificial para o processo de endurecimento por precipitação.

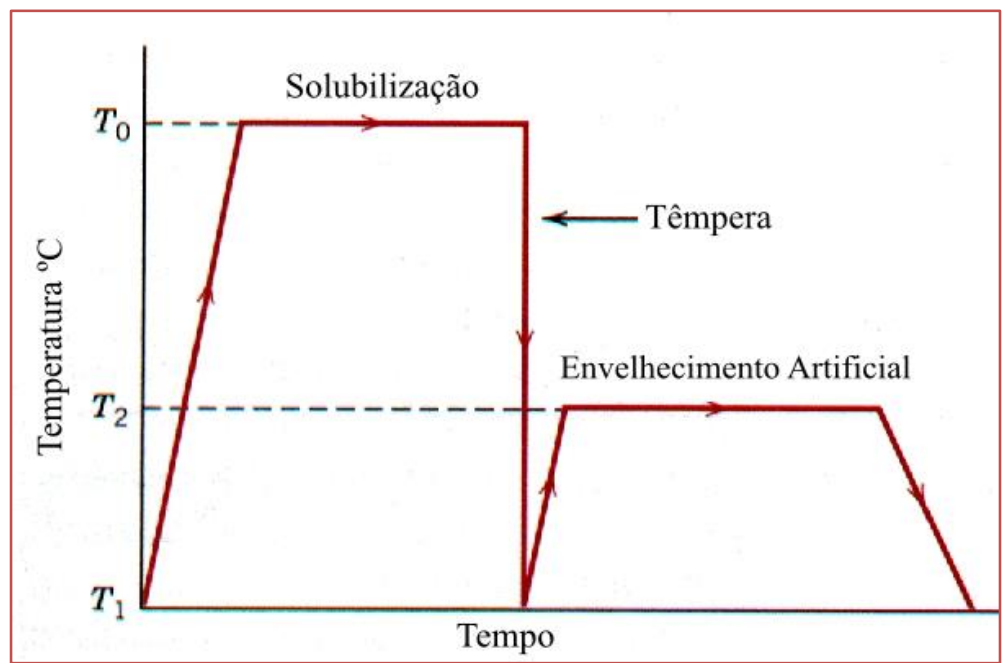

\section{MATERIAIS E MÉTODOS}

Para a realização da fusão do alumínio A356 (Al-7Si-0,3Mg) foi utilizado um forno Sauder de $1500 \mathrm{~kg}$ com temperatura média de $740^{\circ} \mathrm{C}$, o forno foi alimentado por meio de lingotes de alumínio. 0 alumínio derretido sofreu um tratamento químico de com $2 \mathrm{~kg}$ de Zendox afim de eliminar a presença da formação de óxidos e a inclusão do refinador de grãos TiBAl3 (Nucleant 100) com o intuito diminuir e refinar os grãos dendríticos. Foi realizado a variação do teor de nucleante nas concentrações de 0,06\% e 0,08\% em relação ao forno, assim como a correção dos elementos de liga de $\mathrm{Sr}$ e $\mathrm{Mg}$ com $0,54 \mathrm{~kg}$ e $0,44 \mathrm{~kg}$ respectivamente. Foi realizado o tratamento de desgaseificação no alumínio fundido utilizando N2 em fluxo constante de $5 \mathrm{~L} / \mathrm{min}$ com rotação média de $260 \mathrm{Rpm}$.

0 vazamento do alumínio fundido ocorreu por gravidade em molde permanente com temperatura média de $380^{\circ} \mathrm{C}$ e com tempo de vazamento e solidificação de $15 \mathrm{~s}$ e 110 s respectivamente, utilizando macho de areia shell. A peça produzida é parte integrante do sistema de amortecimento da motocicleta, as amostras utilizadas para realização dos ensaios de microscopia óptica e ensaios mecânicos foram retiradas da peça conforme mostra a fig. 2.

Figura 2. Peça utilizada para a realização das análises

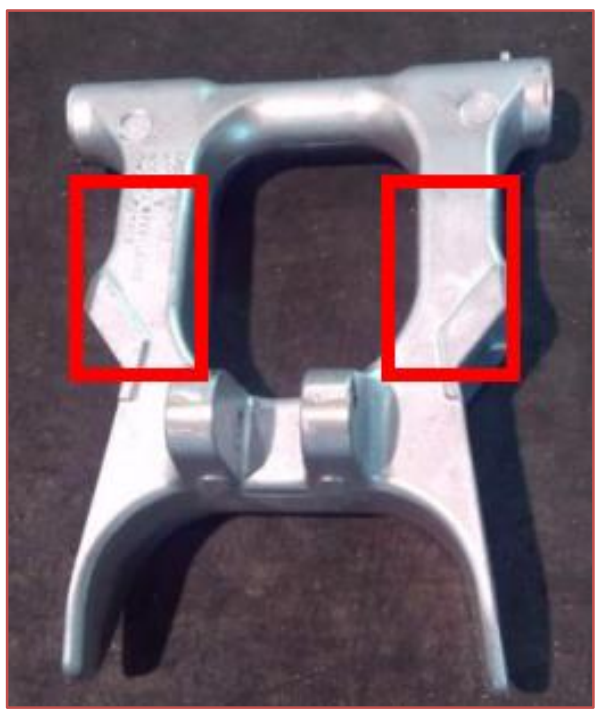


Tabela 1. Composição Química Liga de Alumínio A356 em peso (\%).

\begin{tabular}{|c|c|c|c|c|c|c|c|c|c|}
\hline $\mathrm{Cu}$ & $\mathrm{Si}$ & $\mathrm{Mg}$ & $\mathrm{Zn}$ & $\mathrm{Fe}$ & $\mathrm{Mn}$ & $\mathrm{Ni}$ & $\mathrm{Ti}$ & Allnt & $\mathrm{Al} \%$ \\
\hline 0.3636 & 7,071 & 0,3315 & 0,013 & 0,2303 & 0,0078 & 0,09 & 0,1055 & 7,218 & 92,18 \\
\hline
\end{tabular}

A análise química da liga foi realizada em um espectrômetro de emissão Shimadzu PDA-7000 pelo método PDA (análises de distribuição de pulsos) mostrado na tabela 1. Para análise da microestrutura foi realizado procedimento de metalografia (ASTM E 40770 - Microetching Metal and Alloys). 0 corte transversal foi realizado com o auxílio de uma politriz, o embutimento a quente foi feito com $16 \mathrm{~g}$ de baquelite a $150^{\circ} \mathrm{C}$ a $10 \mathrm{~min}$. Para o lixamento foram utilizadas lixas com granulação nos tamanhos: 600 , $800,1000,1200,1500$ e 2500 , com duração de 10 min cada para cada lixa. Todas as amostras foram giradas no ângulo de $90^{\circ}$, o polimento deu-se com aluminas nas granulometrias de $0,3 \mu \mathrm{m}$ e $0,05 \mu \mathrm{m}$, o ataque químico revelador foi realizado com keller com duração de $10 \mathrm{~s}$. As imagens foram capturadas em um microscópio óptico Olympus CX 41, afim de identificar a microestrutura das amostras que sofreram e não sofreram o tratamento térmico e a variação nos teores de refinador de grãos.

As amostras para o ensaio de tração foram confeccionadas segundo o padrão da norma JIS-Z 2241 cujo a dimensão é mostrada na fig. 3. de modo a avaliar as propriedades mecânicas. 0 teste foi realizado em uma máquina universal de tração Instron, com célula de carga de $100 \mathrm{kN}$, velocidade de ensaio de $20 \mathrm{Mpa} / \mathrm{s} \mathrm{e}$ com extensômetro de $2,5 \mathrm{~mm}$

Figura 3. Dimensões especificadas pela norma para elaboração do corpo de prova.

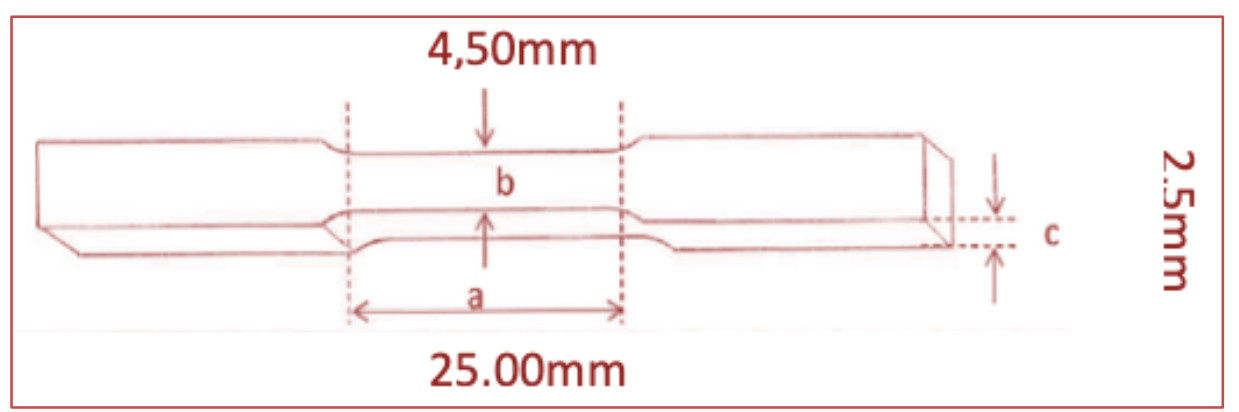

\section{RESULTADOS E DISCUSSÕES}

A microestrutura da liga de alumínio A356 analisada na fig. 4 é caracterizada por uma formação dendrítica de Al $\alpha$ e Si eutético. Comparando as fig 4. a), b), d) e e) observamos através das imagens que a alteração na concentração do refinador de grãos modificou a microestrutura da liga através da esferiodização e na diminuição dos grãos de Ala que está envolto de uma fase de Si eutético (OLIVEIRA, 2014). Após o tratamento térmico de solubilização e precipitação percebe-se através das fig. 4 e) e f) que houve um aumento do tamanho dos grãos assim como um arredondamento, a fase de sílicio eutético sofreu um coalescimento e esferiodização aumentando a formação dos precipitados de Si eutético. 
Figura. 4 Microestruturas da liga de alumínio A356: a) 0,06\% de RG, 40x; b) 0,06\% de RG, 100x; c) 0,06\% de RG com tratamento térmico T6, 100x; d) 0,08\% de RG, 40x; b) 0,08\% de RG, 100x; c) 0,08\% de RG com tratamento térmico $\mathrm{T} 6,100 \mathrm{x}$.

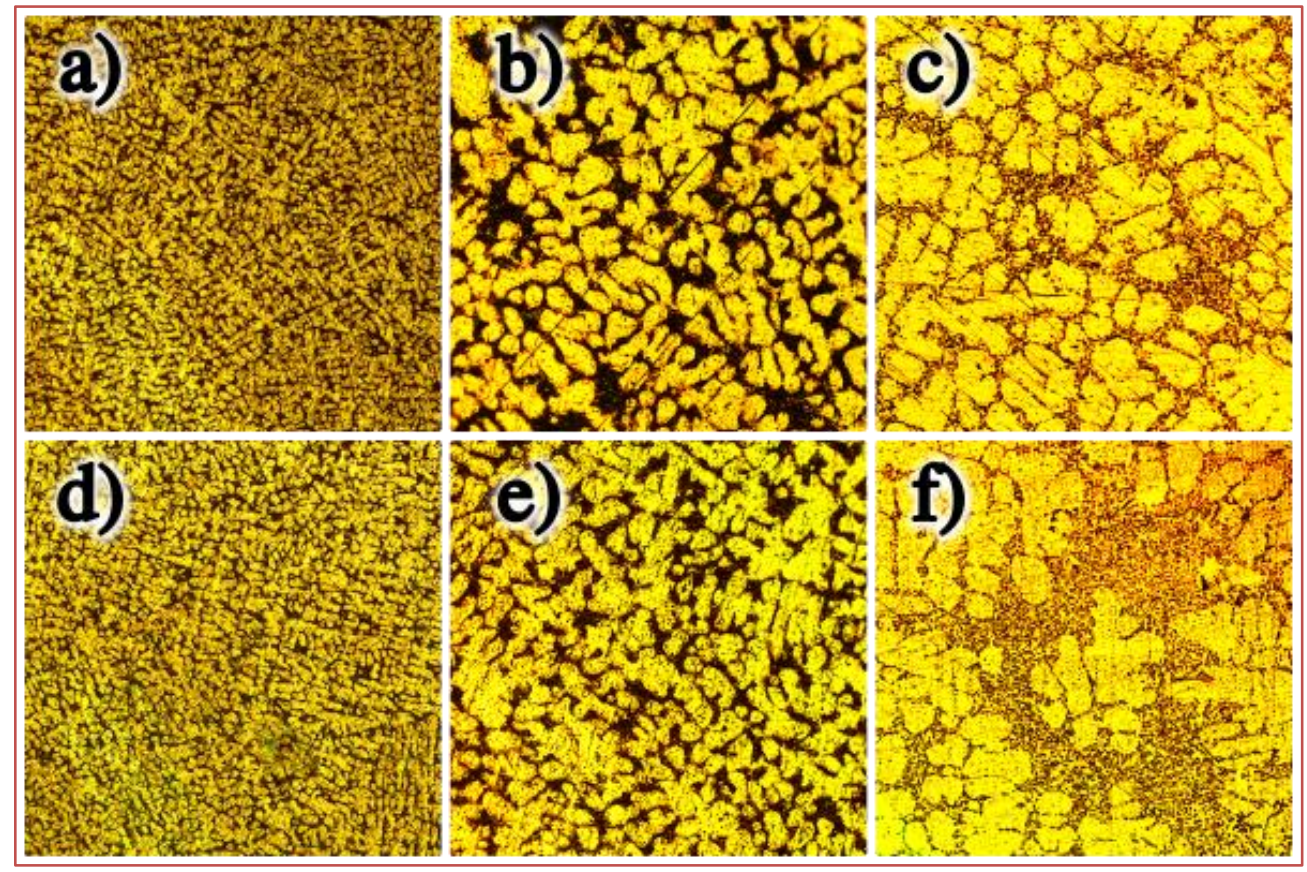

0 resultado do ensaio de tração mostrou que aumentando o percentual de refinador de grãos na liga de alumínio A 356 a propriedade alongamento aumentou.

A partir dos resultados do ensaio de tração percebe-se que os valores de limite de escoamento, resistência a tração e alongamento das amostras produzidas com $0,08 \%$ de refino de grãos foram superiores às amostras contendo apenas 0,06\% mostrando sua influência diretamente nas propriedades mecânicas, assim como é possível observar na tabela 2 e 3.

Tabela 2. Resultado do ensaio de tração (0,06\%) de refinador de grãos.

\begin{tabular}{|c|c|c|c|}
\hline \multirow{2}{*}{ Amostras } & Limite de Escoamento & Resistência a Tração & Alongamento \\
\hline 1 & 168,47 & 237,60 & $1,99 \%$ \\
\hline 2 & 147,50 & 222,68 & $1,65 \%$ \\
\hline 3 & 111,30 & 190,67 & $1,38 \%$ \\
\hline 4 & 134,69 & 202,56 & $1,71 \%$ \\
\hline Média & 140,49 & 213,38 & $1,68 \%$ \\
\hline
\end{tabular}

Tabela 3. Resultado do ensaio de tração $(0,08 \%)$ de refinador de grãos.

\begin{tabular}{|c|c|c|c|}
\hline \multirow{2}{*}{ Amostras } & Limite de Escoamento & 255,41 & Alongamento \\
\hline 1 & 184,37 & 248,19 & $6,49 \%$ \\
\hline 2 & 177,56 & 260,99 & $6,93 \%$ \\
\hline 3 & 197,01 & 266,59 & $6,42 \%$ \\
\hline 4 & 195,39 & 257,80 & $6,43 \%$ \\
\hline
\end{tabular}




\section{CONCLUSÃO}

Observou-se a partir das microestruturas analisadas que o aumento no teor de refino de grãos no banho influenciou para a presença de grãos mais refinados, menores e mais esferiodizados.

0 ensaio de tração mostrou que com o aumento do refino de grãos na liga de alumínio A 356 as propriedades mecânicas também aumentaram consideravelmente.

O aumento das propriedades mecânicas da peça que é parte integrante do sistema de amortecimento da motocicleta, influenciou positivamente para o aumento da resistência, durabilidade e garantia do produto final.

\section{REFERÊNCIAS}

[1] NETO, J.D.M,; DA SILVA, R.N.A.; DE FREITAS, B.M.; NETO, J.E.; DOS SANTOS, M.D. Estudo comparativo da microestrutura e microdureza da liga $\mathrm{Al}-5 \% \mathrm{Si} 0,3 \% \mathrm{Mg}$ antes e após o tratamento térmico T6. In: Congresso Técnico Científico da Engenharia e da Agronomia CONTTEC', Fortaleza, CE, 2015. Anais... Disponível em http://72soea.soea.org.br/anais/. Acesso em 18 de Junho de 2018.

[2] OLIVEIRA, R.O.M.; ROCHA, F.L. Tratamento térmico de precipitação - t6 aplicado em roda de liga leve de motocicleta. Holos, v. 5, n. 30, p. 372-382, 2014.

[3] CHEN, X.-G.; FORTIER, M. TiAISi intermetallic formation and its impact on the casting processing in Al-Si alloys. Journal of Materials Processing Technology, v. 210, p. 1780-1786, 2010.

[4] DA SILVA, C.C. Efeito de inoculantes para refino de grão e modificador de eutético na curva de resfriamento da liga a356 e da liga a356 reciclada. 2016, 147p. Tese (Doutorado em Engenharia Mecânica - Materiais) Universidade Estadual Paulista, UNESP, Guaratinguetá.

[5] GRUZLESKI, J.E.; The Treatment of Liwuid Aluminum-Silicon Alloys: Des Plaines, III. American Foundrymen's Society, p. 25-91, 1990.

[6] CUPINI, N. L. Desenvolvimento de um Processo para Refino de Grão do Alumínio Fundido Baseado na Aplicação de Recobrimentos Voláteis à Interface Metal/Molde. 1978, 259p. Tese (Doutorado em Engenharia Mecânica) Universidade Estadual de Campinas, UNICAMP, Campinas, 1978.

[7] SEGUNDO, E.H; VERRAN, G.O.; BATISTA, G.M. Análise dos efeitos dos tratamentos térmicos de solubilização e envelhecimento artificial sobre a microestrutura da liga de alumínio A356. Revista Matéria, v. 20, n. 4, p. 936-945, 2015.

[8] LI, R.X.; LI, R.D.; ZHAO, Y.H.; HE, L.Z.; LI, C.X.; GUAN, H.R.; HU, Z.Q. Age-hardening behavior of cast Al-Si base alloy. Materials Letters, v. 58, p. 2096-2101, 2004.

[9] SMITH, W.F., Princípios de Ciência e Engenharia dos Materiais. Portugal: McGraw-Hill, 1998.

[10] CALLISTER, W.D.; RETHWISCH, D.G. Ciência e Engenharia de Materiais. Uma Introdução.

[11] MOREIRA, P. S. Efeito da taxa de resfriamento e dos tratamentos térmicos sobre as propriedades mecânicas da liga Al-Si-Mg (A356.0). Minas Gerais, 2011. Dissertação (Mestrado em Engenharia de Materiais) Universidade Federal de Outro Preto, UFOP, Ouro Preto, 2011.

[12] FURLAN, T.S. Influência do teor de estrôncio na modificação da liga A356. 2008,178p. Dissertação (Mestrado em Engenharia Metalúrgica e de Materiais) Escola Politécnica da Universidade de São Paulo, USP, São Paulo.

[13] ASTM E 407-93. Standard Practice for Microetching Metals and Alloys. USA: ASTM International,1997.

[14] ASM. Introduction to Aluminum Alloys and Tempers. J. Gilbert Kaufman, p. 9-22. ASM International, 2000.

[15] JIZ Z 2201. Test pieces for tensile test for metallic materials. Japanese Standards Association, 1998. 


\section{Capítulo 10}

\section{Os requisitos de scaffolds para regeneração meniscal}

\section{Raquel Rosa de Souza}

Ênio César Machado Fagundes

Durval João De Barba Junior

Cláudia Ciceri Cesa

Thiago Farias Bujes

Carmen Iara Walter Calcagno

Resumo: Scaffolds são peças promissoras no tratamento de lesões meniscais, pois possibilitam o estabelecimento das funções do menisco. No entanto, estes implantes não estão disponíveis no Brasil. Assim, existe um campo em aberto de investigação de materiais capazes de serem moldados e testados nacionalmente. Deste modo, por meio de uma revisão literária, este projeto visa elencar os requisitos destes dispositivos. As bases acadêmicas PubMed e Science Direct foram utilizadas para pesquisar as publicações dos últimos 10 anos que apresentassem os termos: "meniscus" e "scaffold" (presentes no título/resumo); "tissue" e "repair" ao longo do texto. Os resumos resultantes foram avaliados e 59 publicações, no idioma inglês, foram selecionadas. Um quadro dos requisitos que um scaffold para regeneração meniscal deve possuir foi gerada, incluindo informações sobre suas funções e a quantificação de suas características físicas/químicas. Esta lista poderá auxiliar na decisão de profissionais acerca da fabricação e escolha de materiais para protótipos meniscais.

Palavras-chave: Scaffold, regeneração meniscal, revisão sistemática, requisitos.

*0 artigo foi apresentado e publicado nos anais do 23 CBECiMat - Congresso Brasileiro de Engenharia e Ciência dos Materiais 


\section{INTRODUÇÃO}

0 menisco, medial e lateral, faz parte dos componentes essenciais para o funcionamento do mecanismo do joelho. Os meniscos são discos fibrocartilaginosos em formato de C, situados entre o côndilo femoral e o planalto tibial(1-12). Eles são compostos por uma matriz extracelular constituída maioritariamente por água e por colágeno e em baixas quantidades por glicosaminoglicanos (GAGs) $(13,14,8)$. As fibras de colágeno são orientadas tanto de maneira circunferencial como radial permitindo propriedades mecânicas anisotrópicas aos meniscos $(2,3,9,13)$. Esta complexa estruturação faz com que o menisco seja considerado uma das articulações mais complexas do corpo humano(15). Ele executa o papel de lubrificante, amortecedor, estabilizador da junta do joelho e transmissor de tensões $(4,10,15-23)$.

Os danos meniscais fazem parte das lesões mais comuns no joelho(24), frequentemente ocorrem devido a impactos durante a prática esportiva ou resultam da degeneração da articulação conforme o envelhecimento(1,14,15,20,25,26). A maioria das fraturas localizam-se nas partes avasculares do menisco (região sem espontânea regeneração) ocasionando dores acentuadas e mudanças degenerativas no conjunto do joelho, como a osteoartrose $(2,5,13-16,18,20,25,27)$. As estratégias para correção das lesões são complexas. 0 procedimento ortopédicos mais empregado é a meniscectomia que consiste na remoção tecidual da área lesionada(5,14,15,19,21,22,24,26-29). Entretanto a diminuição do tecido conduz à perda das funções meniscais e consequentemente ao desenvolvimento da degeneração da cartilagem, perturbando a qualidade de vida dos pacientes $(14,21,30)$. Assim, métodos para substituição meniscal estão sendo desenvolvidos e empregados, como é o caso dos aloenxertos e dos scaffolds $(6,15,24,31,32)$.

Procedimentos de transplante meniscais reduzem as dores e restauram a função meniscal. Porém, possuem disponibilidade limitada e podem gerar problemas potenciais de transmissão de doenças $(1,5,8,24,31,33,34)$. Já, os scaffolds possuem como intuito restaurar as funções do menisco pelo crescimento tissular no interior de sua estrutura(21). Atualmente existem dois tipos de scaffolds empregados em cirurgias: o implante meniscal de colágeno (CMI ${ }^{\circledR}$, Menaflex) e o implante de poliuretano (Actifitß), ambos são temporários e comercias na Europa para substituição meniscal parcial (lateral e medial)(14,28,35-37). Também está em análise clinica o Nusurface® para substituição meniscal medial total $(8,9,28)$. Esse implante sintético é permanente, não sofre degradação no corpo e não permite a formação de célula de infiltração.

Nenhum destes três dispositivos estão disponíveis no Brasil. Desta maneira, existe um campo em aberto de investigação e exploração nacional acerca de materiais capazes de serem moldados e testados para atender as necessidades de aplicação como implante meniscal. Por isto, este projeto visa elencar os requisitos destes dispositivos por meio de uma revisão literária. Uma plataforma que contenha os requisitos de um scaffold meniscal permitirá a otimização das suas propriedades por promover uma escolha embasada de materiais e métodos de produção.

\section{METODOLOGIA}

Com intuito de efetuar uma investigação aprofundada sobre as variáveis que influenciam no produto final, a revisão da literatura ocorreu nas bases PubMed e Science Direct de acordo com a seguinte estratégia de busca: as publicações dos últimos 10 anos deveriam apresentar os termos: "meniscus" e "scaffold", presentes no título ou no resumo, e as palavras: "tissue" e "repair" ao longo do texto. Com estas delimitações, obteve-se 130 publicações, 16 pertencentes a ambas as bases. Todos os resumos resultantes foram analisados e submetidos a uma seleção, aqueles que contiveram um entendimento acerca do menisco e sua biomecânica foram selecionados para avaliação aprofundada. Ainda, foram objeto de análise as publicações que permitiram o conhecimento sobre o mecanismo de regeneração tissular a partir de scaffolds, os seus métodos de fabricação e seus limitantes.

\section{RESULTADOS E DISCUSSÃO}

Para MORAN et al. (2015)(38) há limitações acerca do processo de regeneração meniscal, devido à falta de explicações que apresentem com clareza um tipo de scaffold ideal. Deste modo, esta pesquisa teve como intuito desenvolver uma lista dos requisitos para um scaffold meniscal, por meio da leitura prévia dos estudos dos últimos 10 anos resultantes dos critérios de pesquisa empregados. A partir da utilização do critério de seleção, 59 publicações, todas em inglês, foram analisadas por completo. Das quais 18 referemse a artigos de revisão ou de contextualização sobre o cenário meniscal $(2,5,6,8,9,21,20,24,28,31,32,34$ 36,38,40-42), 3 caracterizaram o menisco natural(4,33,43), 15 buscaram avaliação de scaffolds a partir de 
materiais naturais(1,3,16,18,19,22,25,27,29,44-49), 16 por meio de polímeros sintéticos(7,11,12,17,26,30,37,39,50-57) e 7 relacionando tanto materiais biológicos como sintéticos(10,13-15,23,58,59).

A partir da análise das publicações foi possível identificar os fatores chaves que influenciam na restauração das funções meniscais pela utilização de scaffolds. O dispositivo deve apresentar seis propriedades: biocompatibilidade; biodegradabilidade e/ou bioreabsorvibilidade; geometria similar ao menisco nativo; propriedades mecânicas adequadas; porosidade e viabilidade cirúrgica. Essas características relacionam-se entre si e são apresentadas na tabela 1. Para o desenvolvimento de um implante permanente estes não apresentam as propriedades concernentes a degradação e reabsorção, nem proliferação celular(8).

Tabela 1. Requisitos de um scaffold meniscal. Fonte: Autor.

\begin{tabular}{|c|c|c|c|c|c|}
\hline \multicolumn{6}{|c|}{ SCAFFOLD MENISCAL } \\
\hline Função & Descrição & Propriedade do produto & Método de quantificação & $\begin{array}{l}\text { Quantificaçã } \\
\text { o meta }\end{array}$ & \\
\hline \multirow{12}{*}{$\begin{array}{c}\text { agente } \\
\text { sustentador } \\
\text { temporário } \\
\text { para criação } \\
\text { interna de } \\
\text { tecido } \\
\text { meniscal }\end{array}$} & $\begin{array}{c}\text { Evitar rejeição ou } \\
\text { proliferação de organismos } \\
\text { nocivos }\end{array}$ & biocompatibilidade & testes in vitro e in vivo: & \multirow{3}{*}{$\begin{array}{l}\text { ausência de } \\
\text { substâncias } \\
\text { tóxicas }\end{array}$} & \multirow{3}{*}{$(8,9,32)$} \\
\hline & \multirow{3}{*}{$\begin{array}{l}\text { Taxa de degradação } \\
\text { adequada (para garantir uma } \\
\text { estruturação do novo } \\
\text { tecido).sem a geração de } \\
\text { substâncias toxicas }\end{array}$} & \multirow{3}{*}{$\begin{array}{l}\text { biodegradabilidade e/ou } \\
\text { bioreabsorvibilidade }\end{array}$} & análise histológica & & \\
\hline & & & teste de citotoxicidade & & \\
\hline & & & $\begin{array}{l}\text { cálculo da taxa de } \\
\text { degradação }\end{array}$ & $\geq 12$ meses & $(8,38)$ \\
\hline & $\begin{array}{l}\text { Geometria similar ao do } \\
\text { menisco natural }\end{array}$ & $\begin{array}{l}\text { formato similar ao } \\
\text { menisco natural ou } \\
\text { habilidade de ajustar sua } \\
\text { geometria durante } \\
\text { implementação }\end{array}$ & $\begin{array}{c}\text { Ressonância magnética } \\
\text { do joelho do paciente } \\
\text { para verificação de } \\
\text { medidas }\end{array}$ & - & $(8,9,35)$ \\
\hline & \multirow{3}{*}{$\begin{array}{c}\text { Possuir funções } \\
\text { biomecânicas que atendam } \\
\text { as necessidades do paciente. } \\
\text { Isto deve ocorrer até o fim do } \\
\text { processo de regeneração } \\
\text { tissular }\end{array}$} & \multirow[t]{2}{*}{ resistência mecânica } & teste de tração & $\begin{array}{l}\text { resistência } \\
\text { entre } 75 \text { - } \\
150 \mathrm{Mpa}\end{array}$ & \multirow{3}{*}{$\begin{array}{c}(3,8,9,16, \\
17, \\
20,22,23, \\
31,32,39, \\
43,50)\end{array}$} \\
\hline & & & teste de compressão & $\begin{array}{l}\text { modulo de } \\
75-150 \mathrm{Kpa}\end{array}$ & \\
\hline & & $\begin{array}{c}\text { propriedades } \\
\text { tribológicas adequadas }\end{array}$ & teste de fricção & $\begin{array}{l}\text { coeficiente } \\
\text { de fricção } \\
\leq 0,05\end{array}$ & \\
\hline & \multirow{3}{*}{$\begin{array}{l}\text { O implante deve promover } \\
\text { aderência e proliferação } \\
\text { celular }\end{array}$} & \multirow{3}{*}{ estrutura porosa } & \multirow{2}{*}{$\begin{array}{c}\text { MEV e softwares de } \\
\text { imagem }\end{array}$} & $\begin{array}{l}\text { macroporos: } \\
200-300 \mu \mathrm{m}\end{array}$ & \multirow{3}{*}{$\begin{array}{l}(3,8,9,16, \\
17,32,38)\end{array}$} \\
\hline & & & & $\begin{array}{l}\text { microporos: } \\
10-50 \mu \mathrm{m}\end{array}$ & \\
\hline & & & cálculo da porosidade & $\begin{array}{l}\text { porosidade } \\
\text { da estrutura } \\
\geq 70 \%\end{array}$ & \\
\hline & $\begin{array}{c}\text { Compatível com as práticas } \\
\text { cirúrgicas }\end{array}$ & viabilidade cirúrgica & teste de corte e de sutura & - & $(8,25,48)$ \\
\hline
\end{tabular}

A propriedade primária para a escolha do material para a fabricação de scaffold meniscal é a biocompatibilidade. Pois, deve-se evitar a rejeição do dispositivo ou proliferação de organismos nocivos ao corpo humano. Por isto, alguns estudos escolhem materiais naturais(38,42) como o colágeno(48) e a seda(18,22). Um dos métodos para a produção de scaffold de matriz extracelular é o processo de descelularização de meniscos(1,19,25,27,29,44,58). Estes dispositivos irão oferecer uma estrutura regenerada similar ao tecido natural(25) mas, com propriedades mecânicas limitadas(9). Para contornar este problema, adição de materiais ou de outros métodos de processamentos podem ser empregadas ao menisco descelularizado(1,58). 
Pelo fato de os materiais naturais não possuírem grande disponibilidade ou elevada resistência mecânica, scaffolds a base de materiais sintéticos veem sendo foco de inúmeros estudos, tendo em destaque os polímeros: poliuretano (PU), poli(ácido lático) (PLA) e poli-ع-caprolactona (PCL) $(27,57)$. Os implantes a base de polímeros sintéticos apresentam excelentes propriedades mecânicas e processamento bem flexíveis, entretanto podem ocasionar problemas de biocompatibilidade(1,3,9,38). Um dos métodos de fabricação empregado é o do electrospinning(10-13,30,51,52,55,56,58), o qual reproduz uma estrutura similar das orientações da fibra de colágeno(31) e possibilita a fabricação de scaffold celularizados $(11,12,51,52,56)$. No entanto, é considerado lento, apresenta propriedades mecânicas limitadas e emaranhados densos(31,54). Estudos demonstram que aplicação de fibras secundárias de sacrifício (como de poli(óxido de etileno)-PE0) são promissoras para aumentar a porosidade do scaffold(13,51,52). Outra tecnologia que está ganhando destaque é a manufatura aditiva(7,9,55). A metodologia da criação de scaffold meniscal com dimensões personalizadas ao paciente pelo método de impressão 3D está sendo desenvolvida por CENGIZ et al. (2016)(7). 0 procedimento de bioimpressão apresenta desafios no desenvolvimento de sua formulação pelo fato de requerer que esta seja tanto biocompatível como imprimível(9).

Estudos iniciais acerca de implantes meniscais focavam na produção de uma estrutura permanente e resistente. Empregavam materiais não reabsorvíveis, como o Teflon e o Dácron, produzindo resultados insatisfatórios (inflamações)(8,32). Após, procurou-se desenvolver dispositivos que interagissem com o organismo, gerando estruturas porosas que degradavam-se e/ou que seriam absorvidas enquanto permitiriam a criação tissular em seu interior(32). RONGEN et al. (2014)(8) apresentam duas diretrizes para a construção de substitutos para os defeitos meniscais: um dispositivo permanente, não reabsorvível, e outro biodegradável e/ou reabsorvível. Deste modo, os scaffolds devem possuir uma taxa de degradação e/ou absorção adequada para permitir uma estruturação tecidual que promova um suporte mecânico(40), aconselha-se esta taxa a ser de pelo menos 12 meses(8). Além disto, os produtos da degradação devem ser atóxicos $(8,9,32)$.

A fim de garantir uma estruturação correta da articulação o implante deve possuir formato e tamanho similar ao menisco natural, preferencialmente considerando a anatomia específica do menisco que será empregado(8,9). Deverá ser previsto no projeto as possíveis alterações de dimensionamento e fixação que ocorrerão no scaffold quando empregado ao corpo humano(8). Por questões de segurança os implantes empregados atualmente são superdimensionados, $10 \%$ maiores do que a área mensurada correspondente ao defeito meniscal(35). É aconselhável um dimensionamento maior, pois um tamanho menor irá aumentar a pressão no scaffold fazendo com que seja susceptível a falha8.

Outro aspecto importante é que o arcabouço deve possuir funções biomecânicas que atenderão as necessidades do paciente $(16,17,50)$. Isto deve ocorrer até o fim do processo de regeneração tissular(3). Para evitar abrasão e rompimento do conjunto do joelho até que o novo tecido produza sua própria zona proteica, considera-se que a propriedade tribológica do implante deva ser próxima ao do menisco nativo, sendo assumido por RONGEN et al. (2014)(8) um coeficiente de fricção menor ou igual à 0,05. Os mesmos autores citam maneiras que auxiliam para o alcance deste coeficiente: redução da porosidade superficial do scaffold, adição de lubrificação e/ou de substâncias antiadesivas(8).

As propriedades mecânicas do implante deverão ser próximas ao do menisco nativo. Para efeitos de comparação, deve-se testar o menisco nativo com a mesma metodologia de caracterização empregada ao material/protótipo de interesse no estudo(8). Segundo RONGEN et al. (2014)(8) a zona de performance mecânica que o dispositivo deve abranger é: um modulo de compressão no intervalo de 75-150 KPa e de tração entre 75-150 MPa. Uma das ressaltas nas propriedades mecânicas do scaffold é a presença de uma memória de forma $(4,22,32,45)$. Os principais testes empregados para a caracterização da performance mecânica são: testes de tração e de compressão(1,3,4,17,18,23,29,30,33,50,51,53,54,58,59).

Outro fator importante para o desenvolvimento de um scaffold é a porosidade em sua estrutura, pois influencia na promoção da aderência e proliferação celular. Ela está ligada com a tendência de formação tecidual no interior do arcabouço(9,16,17,32,38). É necessária que a ordenação dos poros do arcabouço seja avaliada: aconselha-se que deva conter macroporos (para promoção do crescimento tissular medindo em torno de 200-300 $\mu \mathrm{m}$ ), microporos (que auxiliarão na interconectividade interna, sendo de aproximadamente 10-50 $\mu \mathrm{m}$ ) e porosidade elevada (a partir de 70\%)(8). Como foi constatado por ZHANG et al. (2016)(17) estruturas de menor diâmetro em seus poros (250 e 310 em comparação com $515 \mu \mathrm{m}$ ) geraram uma maior proliferação celular devido a possuírem uma maior área de contato efetiva para colonização celular. $\mathrm{O}$ microscópio eletrônico de varredura, MEV, tem sido utilizado para caracterizar a morfologia dos scaffolds, como o tamanho e a distribuição de seus $\operatorname{poros}(1,3,10,12,14,15,18,19,27,29,45,47,53-55,57-59)$. 0 cálculo do dimensionamento do diâmetro dos 
poros pode ser efetuado por softwares de processamento de imagens, como o Image $\mathrm{J}(10,12,13,17,18,51,54,55)$. A porosidade da estrutura pode ser calculada pela massa e volume da amostra como explanado por YUAN et al. (2016)(1), GAO et al. (2016)(44) e LIU et al. (2012)(57).

Por uma abordagem biológica o scaffold deve permitir adesão celular e promover uma rede de restauração, incluindo células meniscais e elementos matriciais(8,9,23). Além disto, deve ser biocompatível e apresentar produtos atóxicos resultantes do processo de degradação ou de interação com o organismo. Para isto são realizados testes laboratoriais, in vitro, e após em animais, in vivo. A degradação dos arcabouços foi determinada nos estudos pela avaliação da taxa de perda de peso da amostra em determinado tempo(3,15). A viabilidade celular e citotoxicidade pode ser observada utilizando kit LIVE/DEAD $(1,16,17,25,27,30,45,51,57)$ e pelo teste MTT(25,58,59). 0 estudo de YUAN et al. (2016)(1) cita que a viabilidade celular foi calculada utilizando a relação entre as células vivas e número total de células. Já GAO et al. (2016)(44) cita a realização de teste de citotoxicidade de acordo com a norma ISO 10993-5.

Por envolver testes em seres vivos, as análises in vivo devem estar de acordo com protocolos de ética estabelecidos pelas instituições de pesquisa. As publicações analisadas escolheram em sua grande maioria modelos de animais pequenos, como coelhos(1,17,49,50,58,59) e camundongo(19). DEPONTI et al. (2013)(2) concluem que do ponto de vista anatômico o menisco caprino é o mais semelhante ao humano e que outros modelos interessantes são os suíno e os ovinos. A escolha do modelo animal leva em consideração fatores financeiras, técnicas e biológicas(2). Previamente animais pequenos são interessantes para ligar os resultados in vitro com in vivo, no entanto, possuem uma relevância clinica prática limitada(2).

Outro aspecto que concerne no projeto de desenvolvimento de um implante meniscal é a sua viabilidade cirúrgica. 0 scaffold deve ser projetado para ser fixado, maleável e cisalhável, mas, ao mesmo tempo, deve possibilitar um procedimento cirúrgico menos invasivo e ser rígido quando posicionado para não danificar o sistema articular(8). Para minimizar o tempo e incisões cirúrgicas dispositivos injetáveis veem sendo estudados, como é o caso de scaffold em gel a base de colágeno(48) e do scaffold ECM injetável de hidrogel a partir da descelularização de menisco suíno(25).

\section{CONCLUSÃO}

A estruturação do método de busca do referencial teórico gerou publicações que auxiliaram na criação do quadro de requisitos de um scaffold meniscal. Pela análise das publicações, não existe um caminho consolidado para desenvolvimento e escolha de materiais para substitutos meniscais. Isto se dá ao fato de as características destes implantes serem interligadas entre si e de explorarem diversas áreas de conhecimento. Seis propriedades foram identificadas como essenciais para garantir o comprimento das funções meniscais: biocompatibilidade; biodegradabilidade e/ou bioreabsorvibilidade; geometria similar ao menisco nativo; propriedades mecânicas adequadas; porosidade e viabilidade cirúrgica. 0 quadro dos requisitos criado poderá auxiliar na decisão de profissionais acerca da fabricação e escolha de materiais para protótipos meniscais.

\section{AGRADECIMENTOS}

Os autores agradecem ao IFSUL/Sapucaia e ao NEOT.

\section{REFERÊNCIAS}

[1] YUAN, Z. et al. AMECM/DCB scaffold prompts successful total meniscus reconstruction in a rabbit total meniscectomy model. Biomaterials, v. 111, p. 13-26, 2016.

[2] DEPONTI, D. et al. Animal models for meniscus repair and regeneration. J Tissue Eng Regen Med, v. 9, n. 5, p. 512-27, 2015.

[3] SAREM, M. et al. Optimization strategies on the structural modeling of gelatin/chitosan scaffolds to mimic human meniscus tissue. Mater Sci Eng C Mater Biol Appl, v. 33, n. 8, p. 4777-85, 2013.

[4] COLUCCINO, L. et al. Anisotropy in the viscoelastic response of knee meniscus cartilage. J Appl Biomater Funct Mater, v. 15, n. 1, p. e77-e83, 2017. 
[5] CHEN, Y. et al. Current advances in the development of natural meniscus scaffolds: innovative approaches to decellularization and recellularization. Cell Tissue Res, v. 370, n. 1, p. 41-52, 2017.

[6] GLORIA, A.; DE SANTIS, R.; AMBROSIO, L. Polymer-based composite scaffolds for tissue engineering. J Appl Biomater Biomech, v. 8, n. 2, p. 57-67, 2010.

[7] CENGIZ, I. F. et al. Building the basis for patient-specific meniscal scaffolds: From human knee MRI to fabrication of 3D printed scaffolds. Bioprinting, v. 1-2, p. 1-10, 2016.

[8] RONGEN, J. J. et al. Biomaterials in search of a meniscus substitute. Biomaterials, v. 35, n. 11, p. 3527-3540, 2014.

[9] MURPHY, C. A. et al. Biopolymers and polymers in the search of alternative treatments for meniscal regeneration: State of the art and future trends. Applied Materials Today, v. 12, p. 51-71, 2018.

[10] LÓPEZ-CALZADA, G. et al. Development of meniscus substitutes using a mixture of biocompatible polymers and extra cellular matrix components by electrospinning. Materials Science and Engineering: C, v. 61, p. 893-905, 2016.

[11] FISHER, M. B. et al. Engineering meniscus structure and function via multi-layered mesenchymal stem cellseeded nanofibrous scaffolds. Journal of Biomechanics, v. 48, n. 8, p. 1412-1419, 2015.

[12] Organized nanofibrous scaffolds that mimic the macroscopic and microscopic architecture of the knee meniscus. Acta Biomaterialia, v. 9, n. 1, p. 4496-4504, 2013.

[13] QU, F. et al. Biomaterial-mediated delivery of degradative enzymes to improve meniscus integration and repair. Acta Biomater, v. 9, n. 5, p. 6393-402, 2013.

[14] FREYMANN, U. et al. Expanded human meniscus-derived cells in 3-D polymer-hyaluronan scaffolds for meniscus repair. Acta Biomaterialia, v. 8, n. 2, p. 677-685, 2012.

[15] WANG, J. et al. Evaluation of novel alginate dialdehyde cross-linked chitosan/calcium polyphosphate composite scaffolds for meniscus tissue engineering. Carbohydrate Polymers, v. 79, n. 3, p. 705-710, 2010.

[16] GROGAN, S. P. et al. Digital micromirror device projection printing system for meniscus tissue engineering. Acta Biomater, v. 9, n. 7, p. 7218-26, 2013.

[17] ZHANG, Z. Z. et al. Role of scaffold mean pore size in meniscus regeneration. Acta Biomater, v. 43, p. 314-326, 2016.

[18] MANDAL, B. B. et al. Multilayered silk scaffolds for meniscus tissue engineering. Biomaterials, v. 32, n. 2, p. 639-651, 2011.

[19] STAPLETON, T. W. et al. Investigation of the regenerative capacity of an acellular porcine medial meniscus for tissue engineering applications. Tissue Eng Part A, v. 17, n. 1-2, p. 231-42, 2011.

[20] MAKRIS, E. A.; HADIDI, P.; ATHANASIOU, K. A. The knee meniscus: Structure-function, pathophysiology, current repair techniques, and prospects for regeneration. Biomaterials, v. 32, n. 30, p. 7411-7431, 2011.

[21] SMITH, N. A.; PARKINSON, B.; SPALDING, T. Meniscal allograft transplantation and meniscal scaffolds; where are we up to now? Orthopaedics and Trauma, v. 29, n. 1, p. 31-37, 2015.

[22] WARNECKE, D. et al. Friction properties of a new silk fibroin scaffold for meniscal replacement. Tribology International, v. 109, p. 586-592, 2017.

[23] PATEL, J. M. et al. One-Year Outcomes of Total Meniscus Reconstruction Using a Novel Fiber-Reinforced Scaffold in an Ovine Model. Am J Sports Med, v. 44, n. 4, p. 898-907, 2016.

[24] VERDONK, P. C. M.; VAN LAER, M. E. E.; VERDONK, R. Meniscus Replacement: From Allograft to Tissue Engineering. Sport-Orthopädie - Sport-Traumatologie - Sports Orthopaedics and Traumatology, v. 24, n. 2, p. 78-82, 2008.

[25] WU, J. et al. An injectable extracellular matrix derived hydrogel for meniscus repair and regeneration. Acta Biomater, v. 16, p. 49-59, 2015.

[26] GU, Y. et al. Repair of meniscal defect using an induced myoblast-loaded polyglycolic acid mesh in a canine model. Exp Ther Med, v. 3, n. 2, p. 293-298, 2012.

[27] MONIBI, F. A. et al. Development of a Micronized Meniscus Extracellular Matrix Scaffold for Potential Augmentation of Meniscal Repair and Regeneration. Tissue Eng Part C Methods, v. 22, n. 12, p. 1059-1070, 2016.

[28] HUTCHINSON, I. D. et al. Restoration of the meniscus: form and function. Am J Sports Med, v. 42, n. 4, p. 987 98, 2014

[29] STABILE, K. J. et al. An Acellular, Allograft-Derived Meniscus Scaffold in an Ovine Model. Arthroscopy: The Journal of Arthroscopic \& Related Surgery, v. 26, n. 7, p. 936-948, 2010. 
[30] BAKER, B. M.; MAUCK, R. L. The effect of nanofiber alignment on the maturation of engineered meniscus constructs. Biomaterials, v. 28, n. 11, p. 1967-1977, 2007.

[31] CHEN, M. et al. The application of electrospinning used in meniscus tissue engineering. J Biomater Sci Polym Ed, v. 29, n. 5, p. 461-475, 2018.

[32] VAN TIENEN, T. G.; HANNINK, G.; BUMA, P. Meniscus Replacement Using Synthetic Materials. Clinics in Sports Medicine, v. 28, n. 1, p. 143-156, 2009.

[33] ABDELGAIED, A. et al. Comparison of the biomechanical tensile and compressive properties of decellularised and natural porcine meniscus. Journal of Biomechanics, v. 48, n. 8, p. 1389-1396, 2015.

[34] BAKER, B. M. et al. Meniscus tissue engineering on the nanoscale: from basic principles to clinical application. J Knee Surg, v. 22, n. 1, p. 45-59, 2009.

[35] MYERS, K. R.; SGAGLiOne, N. A.; KURZWEIL, P. R. A Current Update on Meniscal Scaffolds. Operative Techniques in Sports Medicine, v. 21, n. 2, p. 75-81, 2013.

[36] MOUZOPOULOS, G.; SIEBOLD, R. Partial Meniscus Substitution with Tissue-Engineered Scaffold: An Overview. Clinics in Sports Medicine, v. 31, n. 1, p. 167-181, 2012.

[37] MAHER, S. A. et al. A pre-clinical test platform for the functional evaluation of scaffolds for musculoskeletal defects: the meniscus. Hss j, v. 7, n. 2, p. 157-63, 2011.

[38] MORAN, C. J. et al. Biological augmentation and tissue engineering approaches in meniscus surgery. Arthroscopy, v. 31, n. 5, p. 944-55, 2015.

[39] GALLEY, N. K. et al. Frictional properties of the meniscus improve after scaffold-augmented repair of partial meniscectomy: a pilot study. Clin Orthop Relat Res, v. 469, n. 10, p. 2817-23, 2011.

[40] TAN, G. K.; COOPER-WHITE, J. J. Interactions of meniscal cells with extracellular matrix molecules: towards the generation of tissue engineered menisci. Cell Adh Migr, v. 5, n. 3, p. 220-6, 2011.

[41] MAUCK, R. L.; BURDICK, J. A. From repair to regeneration: biomaterials to reprogram the meniscus wound microenvironment. Ann Biomed Eng, v. 43, n. 3, p. 529-42, 2015.

[42] MONIBI, F. A.; COOK, J. L. Tissue-Derived Extracellular Matrix Bioscaffolds: Emerging Applications in Cartilage and Meniscus Repair. Tissue Eng Part B Rev, v. 23, n. 4, p. 386-398, 2017.

[43] GILBERT, S. et al. Dynamic contact mechanics on the tibial plateau of the human knee during activities of daily living. Journal of Biomechanics, v. 47, n. 9, p. 2006-2012, 2014.

[44] GAO, S. et al. Comparison of glutaraldehyde and carbodiimides to crosslink tissue engineering scaffolds fabricated by decellularized porcine menisci. Materials Science and Engineering: C, v. 71, p. 891-900, 2017.

[45] ALMEIDA, H. V. et al. Anisotropic Shape-Memory Alginate Scaffolds Functionalized with Either Type I or Type II Collagen for Cartilage Tissue Engineering. Tissue Eng Part A, v. 23, n. 1-2, p. 55-68, 2017.

[46] LAKES, E. H. et al. Mechanical Integrity of a Decellularized and Laser Drilled Medial Meniscus. J Biomech Eng, v. 138, n. 3, 2016.

[47] ZITNAY, J. L. et al. Fabrication of dense anisotropic collagen scaffolds using biaxial compression. Acta Biomaterialia, v. 65, p. 76-87, 2018.

[48] PUETZER, J. L.; BONASSAR, L. J. High density type I collagen gels for tissue engineering of whole menisci. Acta Biomaterialia, v. 9, n. 8, p. 7787-7795, 2013.

[49] TORATANI, T. et al. Scaffold-Free Tissue-Engineered Allogenic Adipose-Derived Stem Cells Promote Meniscus Healing. Arthroscopy: The Journal of Arthroscopic \& Related Surgery, v. 33, n. 2, p. 346-354, 2017.

[50] MURAKAMI, T. et al. Establishment of novel meniscal scaffold structures using polyglycolic and poly-l-lactic acids. J Biomater Appl, v. 32, n. 2, p. 150-161, 2017.

[51] SHIMOMURA, K. et al. In Vitro Repair of Meniscal Radial Tear Using Aligned Electrospun Nanofibrous Scaffold. Tissue Eng Part A, v. 21, n. 13-14, p. 2066-75, 2015.

[52] IONESCU, L. C.; MAUCK, R. L. Porosity and cell preseeding influence electrospun scaffold maturation and meniscus integration in vitro. Tissue Eng Part A, v. 19, n. 3-4, p. 538-47, 2013.

[53] HUA-DING, L. U. et al. Whole meniscus regeneration using polymer scaffolds loaded with fibrochondrocytes. Chinese Journal of Traumatology, v. 14, n. 4, p. 195-204, 2011.

[54] FENG, J. et al. Characterization of poly(lactic acid) melt spun fiber aligned scaffolds prepared with hot pressing method. Materials Letters, v. 214, p. 178-181, 2018.

[55] STOCCO, T. D. et al. Design of a novel electrospinning setup for the fabrication of biomimetic scaffolds for meniscus tissue engineering applications. Materials Letters, v. 196, p. 221-224, 2017. 
[56] DRISCOLL, T. P. et al. Fiber angle and aspect ratio influence the shear mechanics of oriented electrospun nanofibrous scaffolds. Journal of the Mechanical Behavior of Biomedical Materials, v. 4, n. 8, p. 1627-1636, 2011.

[57] LIU, C. et al. Influence of perfusion and compression on the proliferation and differentiation of bone mesenchymal stromal cells seeded on polyurethane scaffolds. Biomaterials, v. 33, n. 4, p. 1052-1064, 2012.

[58] GAO, S. et al. An electrospinning fiber reinforced scaffold promoted total meniscus regeneration in rabbit meniscectomy model. Acta Biomaterialia, v. 73, p. 127-140, 2018.

[59] MORADI, L. et al. Regeneration of meniscus tissue using adipose mesenchymal stem cells-chondrocytes coculture on a hybrid scaffold: In vivo study. Biomaterials, v. 126, p. 18-30, 2017. 


\section{Capítulo 11}

\section{Alternativas para substituição de painéis de aço em vagões}

\section{Jean Carlo Tavares}

\section{Leandro da Conceição Medeiros}

Resumo: Perante ocorrências de desgaste acelerado em painéis de aço dos vagões do tipo gôndola, fabricados entre os anos de 2005 e 2013, foi necessário aprofundar a análise dos fatores que influenciaram na precoce perda de espessura dessas chapas que compõem a estrutura dos vagões, falhas essas identificadas nas oficinas de manutenção da empresa de transporte ferroviário, bem como validar um método que possa projetar uma expectativa de vida útil de diferentes tipos de aços já utilizados pelo mercado ferroviário no Brasil e em outros países, levando em conta, testes específicos em laboratório e coleta de dados em campo. Neste artigo demonstra-se, através do custo do ciclo de vida, que a utilização de aço carbono é interessante em curto prazo, porém, em longo prazo, para cenários de possível renovação de concessão a utilização de semi-inox ferrítico, é mais econômica ao longo da vida útil do vagão trazendo menor impacto operacional.

Palavras Chave: vagão, ASTM A-242, inox, revestimento. 


\section{INTRODUÇÃO}

A empresa em estudo é voltada para transporte ferroviário de carga possuindo aproximadamente $6 \%$ da estrutura nacional brasileira, nos quais são transportados cerca de um terço de toda a produção do país. Detém cerca de $20 \%$ da frota ferroviária nacional, em torno de 20 mil vagões e aproximadamente 800 locomotivas. Dos tipos de cargas transportadas o minério de ferro se destaca em volume, sendo utilizado principalmente o vagão do tipo gôndola GDT, cuja frota aproxima-se de 10 mil vagões.

A partir de 2005, a empresa investiu na redução de tara da frota de minério de ferro. Todos os novos vagões gôndola foram modificados, comparados ao projeto original. Naturalmente, os principais objetivos deste projeto foram o alto desempenho e economia de combustível. Essas modificações aumentaram a capacidade útil do vagão em 16,4\%, gerando ganhos de produtividade e eficiência. Entretanto, em 2015, as oficinas de manutenção observaram que esses novos vagões começaram a apresentar preocupante deterioração dos painéis de revestimento, principalmente nas laterais e cabeceiras, gerando impactos operacionais e aumento dos custos de manutenção.

Após estudos realizados pelas áreas de engenharia, planejamento e manutenção, concluiu-se que a corrosão precoce das chapas tem origem na especificação do aço utilizada pelo fabricante de vagões. Assim, foi definido um plano emergencial para substituição parcial ou total das chapas de revestimento, de acordo com os níveis de degradação das séries de vagões fabricados entre 2005 e 2013, totalizando uma necessidade de intervenção em aproximadamente 5.000 vagões.

Nesse sentido, o trabalho tem por objetivo principal analisar e comparar, sob a ótica do LCC ("Life Cycle Cost"), o desempenho da chapa de aço carbono ASTM A-242, aplicada no plano emergencial de manutenção, e o aço semi-inox 410D, material esse já utilizado em outras ferrovias brasileiras e internacionais.

Seu objetivo secundário é validar um método de projeção de vida útil das chapas de aço carbono e semiinox comparando testes de resistência à corrosão, realizados em laboratório, com dados de espessura dos painéis dos vagões, coletados em campo.

As conclusões desse estudo são de fundamental importância, pois a escolha do melhor cenário para tratamento desse problema gerará impactos estratégicos e financeiros nos próximos anos para a empresa.

\section{REVISÃO BIBLIOGRAFICA}

\subsection{CORROSÃO}

A corrosão é um fenômeno espontâneo, geralmente metálico, de destruição gradativa, com perda de material base, devido às modificações químicas e eletroquímicas do meio ambiente, podendo estar associado ou não a esforços mecânicos. Sendo ela um processo destrutivo contínuo diretamente no metal, pode provocar a indisponibilidade do equipamento por perfuração, trincas e solicitações mecânicas (Chiaverini, 1986).

As figuras 1 e 2 demonstram fotos que exemplificam a corrosão identificada em vagões imobilizados em uma das oficinas de manutenção da empresa.

Figura 1: Foto de chapa da lateral

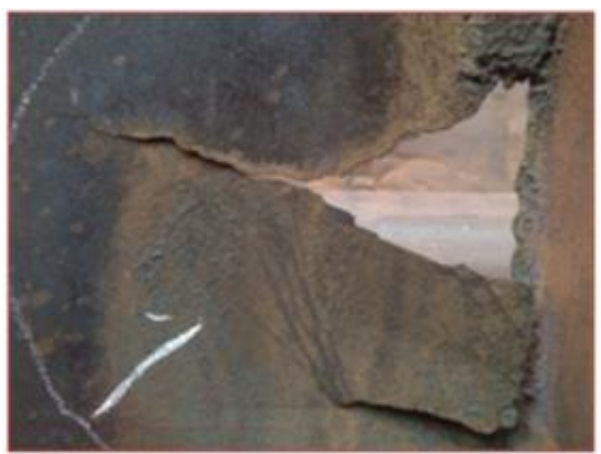

Figura 2: Foto de chapa da cabeceira

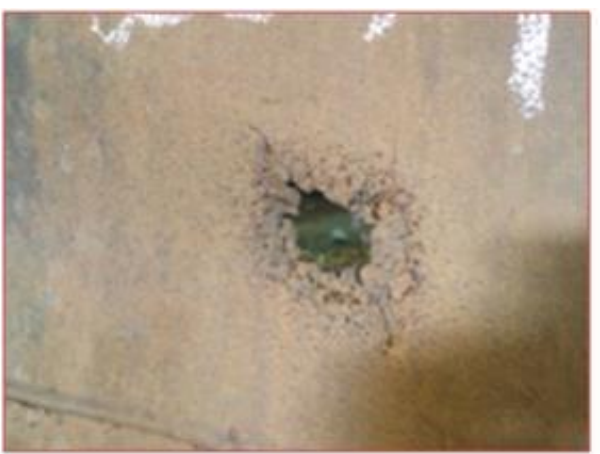


Os metais, geralmente quando submetidos a uma solução aquosa, reagem entre os meios ocorrendo o desprendimento de íons para a solução, gerando uma concentração elétrica de cargas em sua superfície, que segundo Nunes (2007) ocasiona uma diferença de potencial elétrico entre a solução e o metal.

Um dos tipos de corrosão mais comum é a corrosão eletroquímica, principalmente porque seu processo está diretamente associado ao meio úmido, com presença de água ou umidade, onde se encontram várias condições favoráveis para a formação de pilhas ou células de corrosão. Sua formação geralmente ocorre em temperatura abaixo do ponto de orvalho (Telles, 2007).

A taxa de corrosão, ou a taxa de remoção de material - como consequência de ação química -, é um destacado parâmetro de corrosão. Esta pode ser expressa como taxa de penetração de corrosão (TPC), ou perda de espessura do material por unidade de tempo (Callister, 2012). O CPR (Corrosion Penetration Rate), outro termo como pode ser chamado o TPC, é convenientemente expresso tanto em milésimo da polegada por ano (mpy) como milímetros por ano (mm/yr). A norma NACE Standard TM-01-69 (2012) recomenda expressar a taxa de corrosão em mpy ou $\mathrm{mm} / \mathrm{yr}$.

As técnicas eletroquímicas são bastante populares como ferramentas de caracterização dos fenômenos de corrosão, tendo como principal objetivo prever de maneira quantitativa a taxa de corrosão. De acordo com Woynec (2003) o método de extrapolação da reta de Tafel, para determinado potencial de corrosão, determina o valor da taxa de corrosão. Esse mesmo método foi indicado pela equipe do laboratório de corrosão da UMFG como sendo satisfatório para realização do presente trabalho.

A norma NACE RP-07-75 (1999) estabelece a classificação de corrosividade de um meio como àquele que propicia uma taxa de corrosão uniforme e recomenda que a sua aplicação obedeça às faixas na tabela 1.

Tabela 1: Classificação de corrosividade (NACE 1999)

\begin{tabular}{|c|c|c|}
\hline Taxa de Corrosão uniforme $(\mathrm{mm} / \mathrm{ano})$ & Taxa de pite $(\mathrm{mm} / \mathrm{ano})$ & Corrosividade \\
\hline$<0,025$ & $<0,13$ & Baixa \\
\hline 0,025 a 0,120 & 0,130 a 0,200 & Moderada \\
\hline 0,130 a 0,250 & 0,210 a 0,380 & Alta \\
\hline$>0,250$ & $>0,380$ & Severa \\
\hline
\end{tabular}

\subsection{LCC ("LIFE CYCLE COST")}

Segundo Woodward (1997) o custo do ciclo de vida ("Life Cycle Cost" ou LCC) de um produto consiste na soma de todos os custos despendidos com esse produto, desde a sua fabricação e operação até ao fim da sua vida útil.

Outra definição de LCC, semelhante à anterior, que transmite na totalidade a sua essência e é igualmente fácil de compreender é apresentada por Flanagan et al. (1989). De acordo com os autores, o LCC é uma técnica de avaliação econômica que consiste na apuração da totalidade dos custos relacionados com um produto ao longo da sua vida operacional, incluindo não só os custos iniciais, mas também os custos de manutenção, os custos de operação e até os custos ou benefícios resultantes da sua "eliminação".

A escolha do método LCC para cálculo dos cenários de desempenho dos aços analisados se corrobora pelo ponto de vista do consumo, que compreende o tempo desde que um produto é adquirido até que é "eliminado". Essas atividades passam pela aquisição, operação/utilização, manutenção e venda/"eliminação" (Hansen e Mowen, 2005).

Neste sentido, sendo a análise de LCC uma previsão do futuro, diferentes métodos de estimativa de custos poderão ser aplicados, dependendo sempre da disponibilidade de dados e da fase em que estes estão a ser estimados. Fabrycky e Blanchard (1991) propõem três formas de estimação de custos: estimação por analogia, métodos de estimação paramétricos e estimação através de procedimentos de engenharia. Para orientação do presente trabalho foi escolhido esse último citado, devido aos custos serem distribuídos por cada categoria de custos detalhadamente, somando em seguida a sua totalidade. Ainda de acordo com Fabrycky e Blanchard (1991) este método pode resultar numa estimativa bastante precisa se todos os dados necessários estiverem disponíveis. 


\section{METODOLOGIA}

Os métodos utilizados no presente trabalho consistem em ensaios de resistência à corrosão de diferentes tipos chapas de aço carbono e semi-inox e medições de espessura de painéis de vagões em operação, realizadas em campo. 0 cálculo do LCC foi baseado em parâmetros de manutenção vigentes na empresa, juntamente com informações coletadas nos fabricantes dos materiais e insumos envolvidos na recuperação da estrutura dos vagões.

\subsection{ENSAIO DE RESISTÊNCIA À CORROSÃO}

Foram enviadas ao Laboratório de Corrosão e Engenharia Química do Departamento de Engenharia Química da UFMG uma chapa de cada um dos aços identificados da seguinte maneira: aço atual (figura 3), aço novo ASTM A-242 (figura 4) e aço semi-inox (figura 5).

Figura 3: Foto da chapa de aço atual

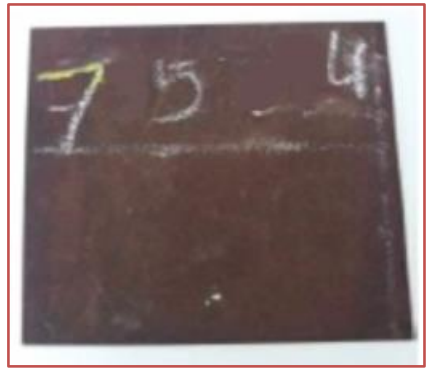

Figura 4: Foto da chapa de aço novo

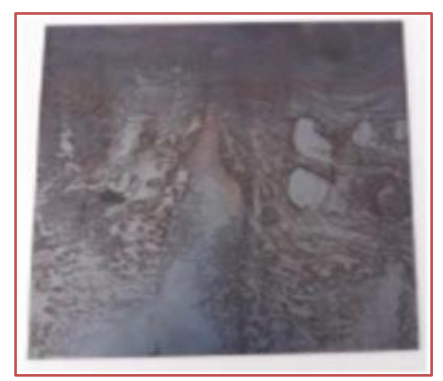

Figura 5: Foto da chapa de aço semi-inox

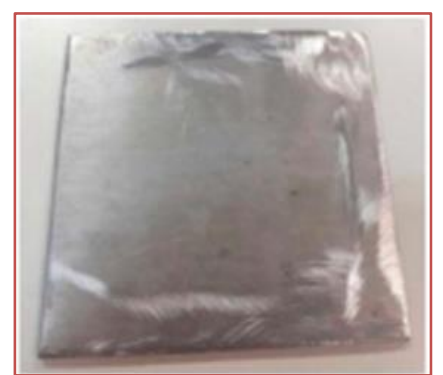

A composição química dos aços indicada na tabela 2 foi utilizada para interpretação dos dados do ensaio de resistência à corrosão.

Tabela 2: Composição química dos aços

\begin{tabular}{cccccccccccc}
\hline \multirow{2}{*}{ Amostra } & \multicolumn{10}{c}{ Elemento } \\
\cline { 2 - 13 } & $\mathrm{C}$ & $\mathrm{Mn}$ & $\mathrm{P}$ & $\mathrm{S}$ & $\mathrm{Si}$ & $\mathrm{Ni}$ & $\mathrm{Cr}$ & $\mathrm{Mo}$ & $\mathrm{Al}$ & $\mathrm{Cu}$ & $\mathrm{Ti}$ \\
\hline Aço atual & 0,110 & 0,643 & 0,024 & 0,005 & 0,366 & 0,009 & 0,457 & 0,006 & 0,039 & 0,001 & 0,001 \\
\hline Aço novo & 0,129 & 0,756 & 0,028 & 0,007 & 0,285 & 0,080 & 0,271 & 0,007 & 0,039 & 0,266 & 0,028 \\
\hline Aço semi-inox & 0,02 & 0,584 & 0,013 & 0,001 & 0,599 & 0,366 & 11,4 & 0,068 & 0,001 & 0,011 & 0,003 \\
\hline
\end{tabular}

De acordo com o relatório técnico do laboratório de corrosão (Lins et al., 2017) além dos elementos citados na tabela 2, o aço semi-inox apresentou teor de nitrogênio inferior a 0,02\%.

A fim de analisar a resistência à corrosão dos aços retratados nas figuras 3,4 e 5 , as chapas foram inicialmente cortadas em amostras com área de $1 \mathrm{~cm}^{2}$ para que fossem realizados os ensaios de polarização e de espectroscopia de impedância eletroquímica. Para tanto, foram afixados às amostras fios de cobre por soldagem com estanho e o sistema foi embutido utilizando-se resina epóxi de cura rápida. Em seguida, as amostras foram lixadas numa politriz metalográfica utilizando lixas d'agua de carbeto de silício (SiC) com granulometrias de 400, 600 e 1200 mesh respectivamente. Os testes foram feitos em duplicata, a fim de confirmar o comportamento de cada amostra avaliada.

Cabe ressaltar que o meio eletrolítico utilizado no laboratório foi uma amostra de água coletada dos drenos de vagões após carregamento de minério, cujo pH foi igual a 6,8, valor esse muito próximo à neutralidade e, portanto, pouco influente sobre sua corrosividade de modo que, de acordo com Lins (2017), a agressividade desta solução pode estar associada aos íons nela presentes, sobretudo os cátions. 
No ensaio de polarização por extrapolação de Tafel, as curvas foram obtidas utilizando taxa de varredura de $1,0 \mathrm{mV} \cdot \mathrm{s}^{1}$, numa janela potencial em torno de $250 \mathrm{mV}$ (vs ECS) em relação ao potencial de circuito aberto previamente estabilizado por 3600 segundos. Os parâmetros da taxa de corrosão foram calculados pelo método de extrapolação de Tafel.

Após os testes de polarização, as amostras foram analisadas por microscopia óptica e fotos dos aspectos da superfície foram registradas.

\subsection{COLETA DE DADOS EM CAMPO}

Para a coleta de dados sobre a espessura das chapas em campo o vagão do tipo GDT teve seus 12 painéis laterais subdivididos virtualmente em 6 seções, denominadas A, B, C, D, E e F conforme figura 6.

Figura 6: Subdivisões virtuais dos painéis do vagão GDT

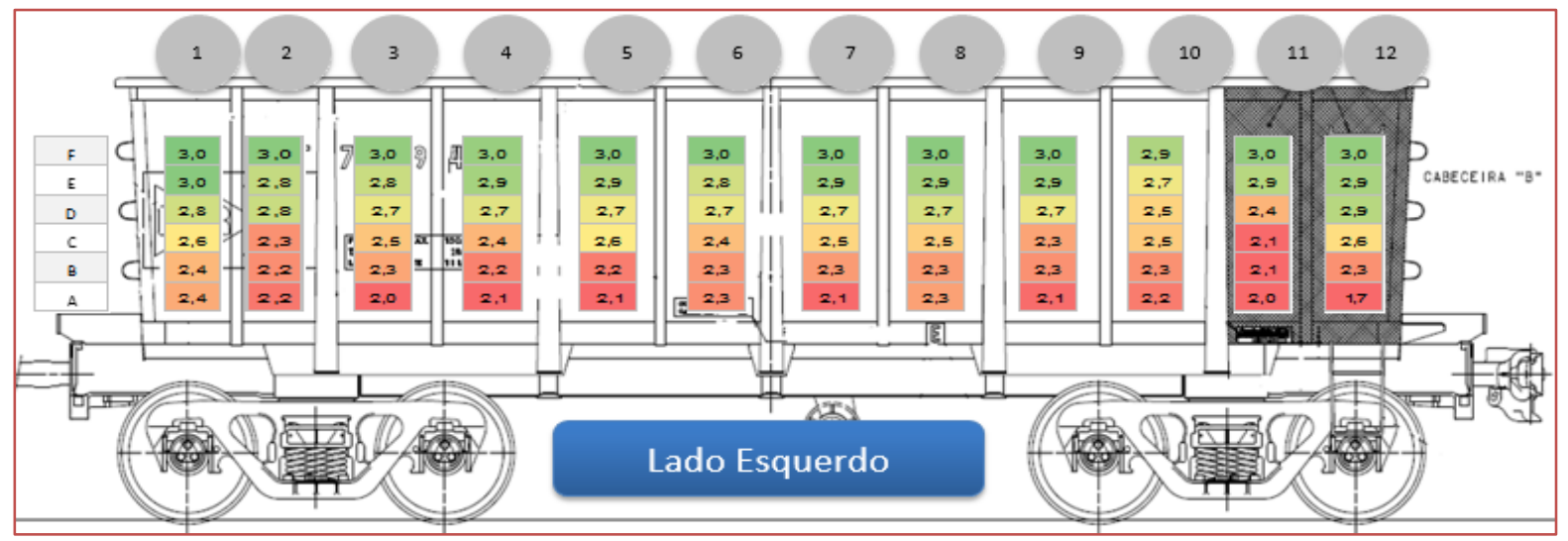

Cada seção originada do corte virtual entre painel versus subdivisão, exemplificados na figura 6, teve sua espessura coletada através de medidor de espessura ultrassônico calibrado. Foram avaliados 282 vagões GDT de diversas séries e anos de fabricação.

Em paralelo à medição de espessura das chapas foi aberta outra frente de coleta de informações com as equipes de manutenção que atuam em campo. Esse trabalho resultou na inspeção visual de 4.172 vagões catalogando trincas nas chapas laterais.

\subsection{PARÂMETROS PARA O CÁLCULO DO LCC}

Explorando a vantagem de customização dos parâmetros de entrada da técnica do cálculo do LCC, foi estipulado que as premissas de engenharia se restringirão apenas à intervenção necessária nos painéis que compõem as chapas laterais, chapas das cabeceiras e as chapas do assoalho. Para esse estudo o custo de aquisição e operação do ativo não terá relevância, pois os vagões alvo do estudo já estão em operação e com ciclo de manutenção definido.

Premissas eleitas para compor o cálculo do LCC:

- Área das chapas dos painéis laterais, das cabeceiras e assoalho;

- $\quad$ Peso especifico dos aços ASTM A-242 e semi-inox 410D;

- $\quad$ Custo / kg das chapas de aços ASTM A-242 e semi-inox 410D;

- Homem x hora (Hxh) médio do mantenedor metalúrgico para recuperação de estrutura;

- $\quad$ Custo do Hxh do mantenedor metalúrgico;

- Quantidade média de gasto de arame MIG para recuperação de estrutura;

- $\quad$ Custo / Kg do arame MIG especifico para cada tipo de aço estudado;

- Q Quantidade média de gás $\left(\mathrm{em} \mathrm{m}^{3}\right)$ utilizada para recuperação de estrutura; 
- $\quad$ Custo $/ \mathrm{m}^{3}$ dos gases específicos para cada tipo de aço estudado;

- Taxa proporcional de corrosão identificada para cada tipo de aço estudado;

- L Limite de desgaste das chapas do assoalho, painéis laterais e de cabeceiras.

\section{ANÁLISE DOS RESULTADOS}

\subsection{TAXA DE DESGASTE DAS CHAPAS ENCONTRADAS EM CAMPO}

Após medição em campo, das chapas laterais de 282 vagões foi possível calcular uma taxa de desgaste, em $\mathrm{mm} /$ ano, levando em conta o ano de fabricação das séries dos ativos. A figura 7 representa o gráfico que mostra o comportamento do desgaste nas subdivisões da figura 6.

Figura 7: Taxas de desgaste obtidas através das medições de espessura em campo

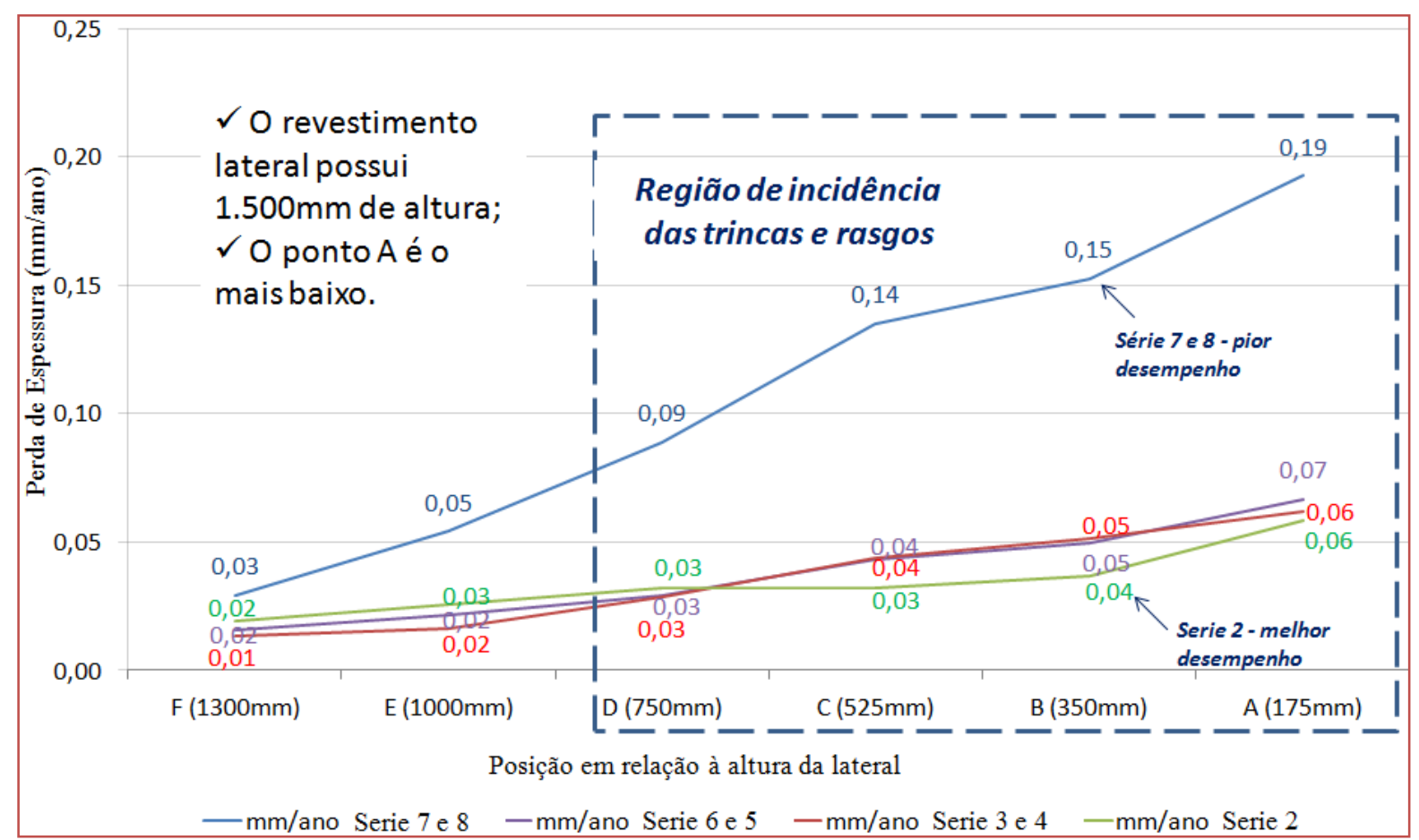

Pode-se notar a partir da análise da figura 7 que o comportamento das séries de vagões de 2 a 6 apresentam taxas de desgaste razoavelmente parecidas, enquanto as séries de vagões 7 e 8 , destoam em muito das outras, chegando a $0,19 \mathrm{~mm} / \mathrm{ano}$, um desempenho 3,2 vezes pior. Interessante observar também que, independente da série, os pontos mais próximos ao assoalho do vagão apresentam maiores valores de corrosão. Esse fato pode ser explicado devido ao fato dessa região geralmente permanecer mais úmida durante o tempo em que os vagões estão carregados com minério.

Com relação à coleta de informações sobre painéis trincados visualmente a figura 8 traz um índice de "percentual de trinca por tempo médio de uso", determinado pela relação do percentual de painéis trincados pelo tempo médio de uso dos vagões. 
Figura 8: Percentual de trinca por tempo médio de uso

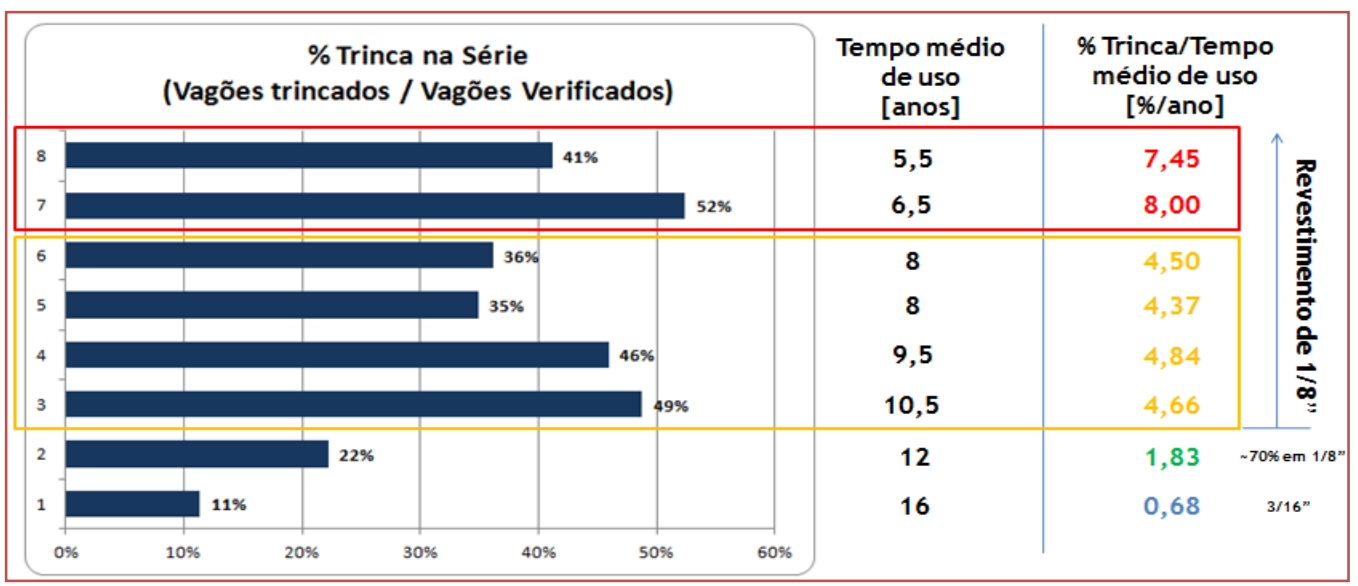

Pode-se perceber que as séries 1 e 2 apresentam percentual muito baixo em relação às demais frotas porém deve-se segregar o desempenho da série 1 devido ao fato de que os painéis de revestimento dessa frota são de espessura diferente.

Análises químicas feitas em várias amostras de chapa de cada uma das séries apresentadas na figura 8 mostraram que as chapas utilizadas na série 2 condizem com as especificações do aço ASTM A-242 enquanto as séries 3, 4, 5 e 6 apresentam várias alterações em seus elementos, principalmente cobre, performando em média, 2,5 vezes menos que a série 2 . As amostras das séries 7 e 8 , que apresentam o pior índice identificado, possuem características que as identificam como sendo um aço patinável com cobre residual, informação essa confirmada pelo fabricante, cujo desempenho apresentou-se em média 4,2 vezes menor do que as chapas da série 2 .

\subsection{TAXA DE CORROSÃO}

Os resultados obtidos no ensaio de polarização mostram que o maior potencial de corrosão (Ecorr) foi observado para o aço semi-inox, conforme figura 9, que apresentou ainda a menor densidade de corrente de corrosão. Isso significa que a amostra de semi-inox é mais resistente à corrosão do que as duas outras amostras avaliadas.

As curvas de polarização dos aços atual e aço novo apresentam perfil bastante similar, com valores próximos de potencial e de densidade de corrente de corrosão.

Figura 9: Curvas de polarização para as amostras de aço (Lins 2017)

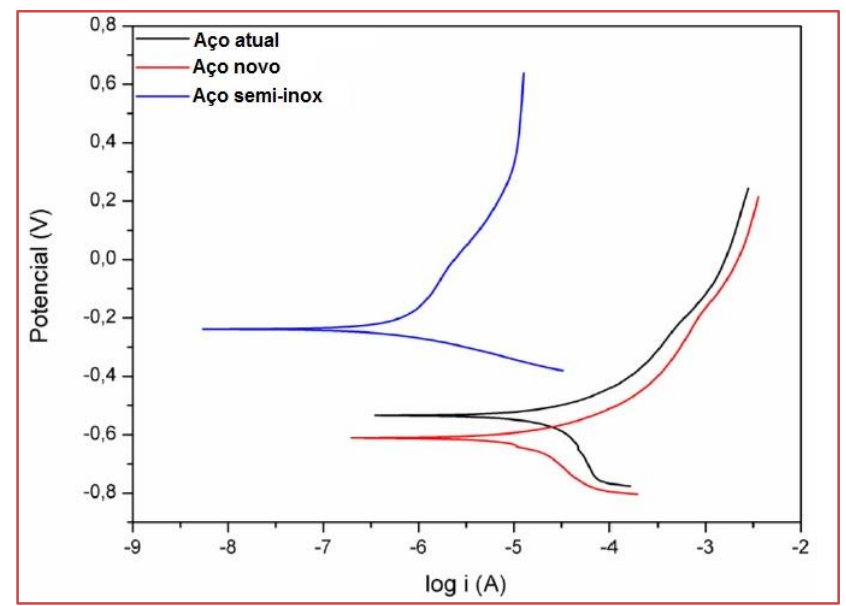


A tabela 3 abaixo mostra o resultado dos parâmetros de Tafel. Pode-se ver que a maior densidade de corrente de corrosão (jcorr) observada para o aço atual implica em uma maior taxa de corrosão $(1,4342$ mm/ano), valor aproximadamente 2,3 vezes maior do que a taxa do aço novo ASTM A-242 $(0,62806 \mathrm{~mm} / \mathrm{ano})$, porém consideravelmente altos quando comparados à taxa de corrosão do aço semiinox (0,018215mm/ano), valor esse 34,5 vezes menor do que o aço novo e 78,7 vezes menor do que o aço atual.

Tabela 3: Parâmetros de Tafel (Lins 2017)

\begin{tabular}{|cccc|}
\hline Amostra & Ecorr $(\mathrm{mV})$ & jcorr $\left(\mu \mathrm{A} / \mathrm{cm}^{2}\right)$ & $\begin{array}{c}\text { Taxa de corrosão } \\
(\mathrm{mm} / \mathrm{ano})\end{array}$ \\
\hline Aço atual & $-534,50$ & 61,87 & 1,4342 \\
\hline Aço novo & $-611,03$ & 27,09 & 0,62806 \\
\hline Aço semi-inox & $-239,03$ & 0,78579 & 0,018215 \\
\hline
\end{tabular}

Conforme relatório técnico do laboratório de corrosão (Lins et al., 2017) o pH do meio eletrolítico utilizado no teste, que se resume à água coletada de drenos do vagão após carregamento, foi igual a 6,8, muito próximo à neutralidade de modo que a agressividade da desta solução pode estar associada a íons nela presentes, sobretudo os cátions, e pelo baixo teor de elementos de liga nos aços atual e novo (ASTM A-242), tornando-os pouco resistentes à corrosão.

Importante ressaltar que a norma NACE RP-07-75 (1999) estabelece a classificação de baixa corrosividade de um meio como àquele que propicia uma taxa de corrosão uniforme inferior a 0,025 mm/ano, portanto, pode-se inferir que entre os diferentes materiais analisados apenas a aplicação do aço semi-inox pode ser considerada satisfatória.

As figuras presentes na tabela 4 ilustram, com um aumento de 100 vezes, o efeito da polarização em cada um dos aços, pelas quais se verifica claramente a presença de produtos de corrosão, sobretudo, nos aços atual e novo. Sobre as mesmas condições eletroquímicas de sobretensão, o aço semi-inox não teve sua superfície consideravelmente alterada, corroborando sua maior resistência à corrosão no referido meio eletrolítico em concordância com os resultados verificados nos ensaios de polarização.

4: Imagens de microscopia antes e depois do ensaio em laboratório (Lins 2017)

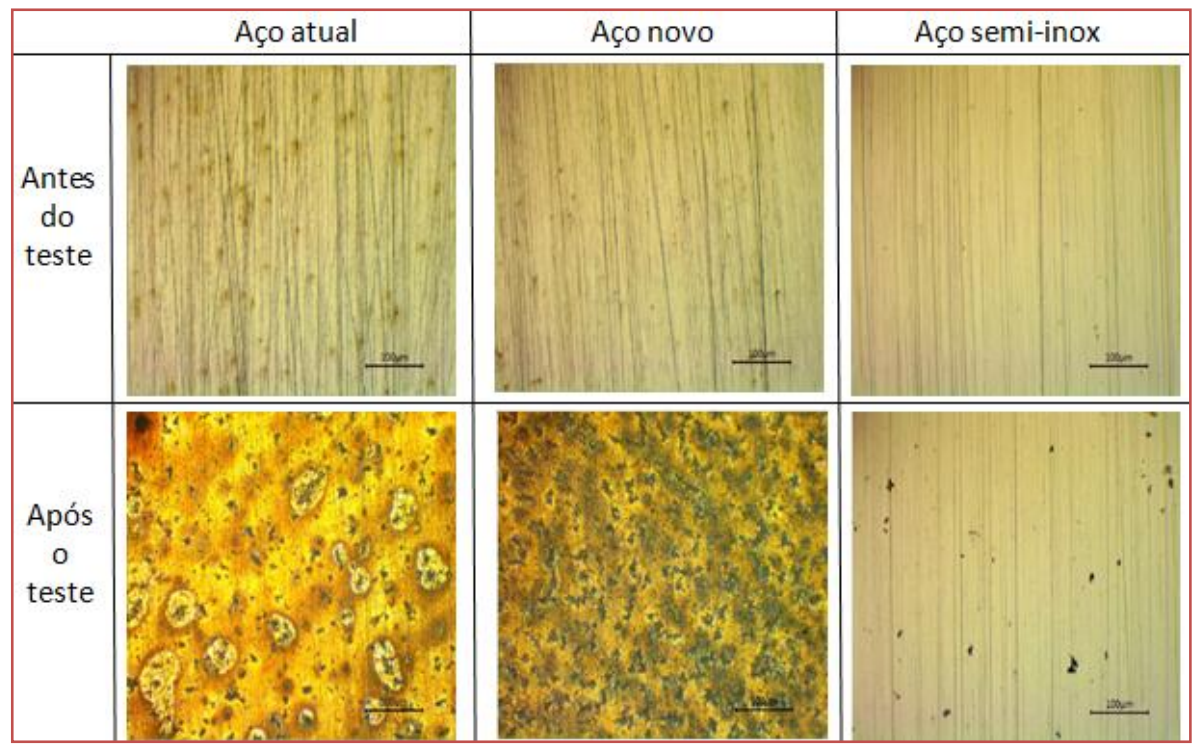




\subsection{RESULTADO DO CÁLCULO DO LCC}

Apesar da definição da norma NACE RP-07-7 sugerir que apenas o aço semi-inox é indicado para exposição à solução aquosa presente no minério de ferro, conforme os resultados dos testes feitos no laboratório de corrosão foi realizada uma comparação de custos entre aplicação do aço ASTM A-242 e o aço semi-inox. Assim como demonstram esses testes, foi identificado um desempenho 2,3 vezes maior do aço ASTM A-242 comparado ao aço atual conforme a tabela 3 "Parâmetros de Tafel". Como essa relação de proporção de durabilidade pôde ser confirmada com as medições feitas em campo, pode-se estimar com alto grau de certeza, que o desempenho da chapa de aço semi-inox segue a mesma projeção vista em laboratório e que seu desempenho com relação ao aço ASTM A-242, para o meio estudado, é 34,5 vezes maior, novamente conforme tabela 3.

Essa alta resistência à corrosão identificada no teste pôde ser observada em campo através da medição da espessura das laterais de um vagão GDT protótipo, que está em operação a 5 anos, cujas chapas de sua estrutura são de aço semi-inox e não apresentaram nenhuma redução de espessura e consequentemente nenhuma trinca em seus painéis de revestimento laterais e de cabeceira, conforme figuras 10 e 11 .

Figura 10: Lateral protótipo semi-inox

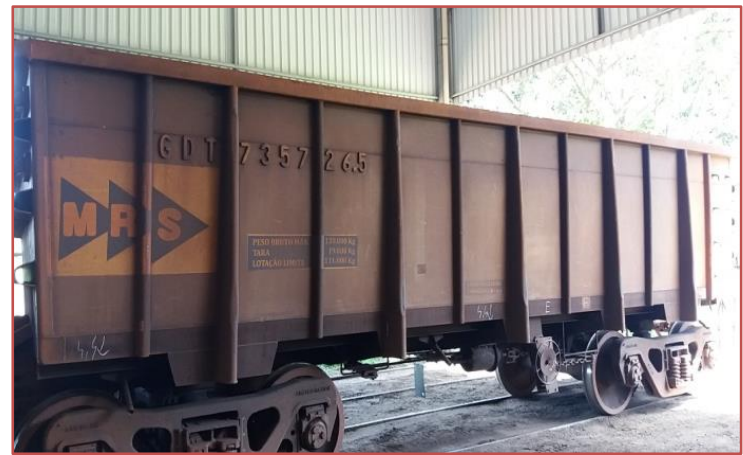

Figura 11: Interior protótipo semi-inox

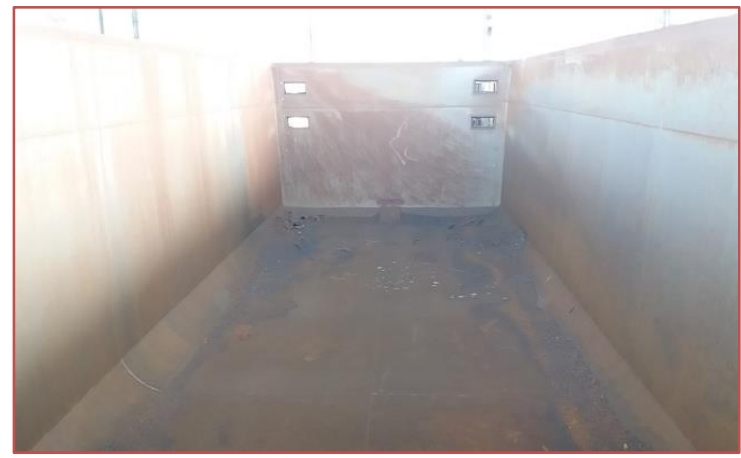

De acordo com o item 5.6.4.1 do documento técnico POP-ENG-1133 utilizado pela empresa o limite operacional de espessura das chapas laterais e de cabeceira, que originalmente apresenta a espessura de $3,2 \mathrm{~mm}$, deve ser de no mínimo de 2,5mm. Esse é o critério de condenação utilizado para realizar a troca das chapas. Com base nesse critério e, levando-se em conta as taxas calculadas a partir das medições feitas em campo apresentadas na figura 7, a vida útil do aço ASTM A-242 nos painéis laterais e de cabeceira, para a operação do vagão GDT é de 11,7 anos e para o assoalho essa vida útil é de 20,8 anos. A vida útil da chapa de aço semi-inox ultrapassa em muito a vida útil do ativo.

Meritório destacar que o cenário do LCC para aplicação do aço ASTM A-242, não leva em conta o impacto operacional na malha ferroviária da empresa que as intervenções em uma frota de 5015 vagões podem causar, mas apenas seu custo financeiro. Sendo assim, uma estimativa de ciclo de aplicação foi realizada levando em conta a capacidade produtiva das oficinas de manutenção que realizam reparo em estruturas, que atualmente atuam de forma corretiva e emergencial nos vagões que já entraram em colapso devido à perda de espessura das chapas, e estão atualmente dimensionadas para atender 70 vagões por mês, o que gera um ciclo de intervenção na frota de 6 anos conforme mostra a figura 12. 
Figura 12: Ciclo de aplicação dos aços

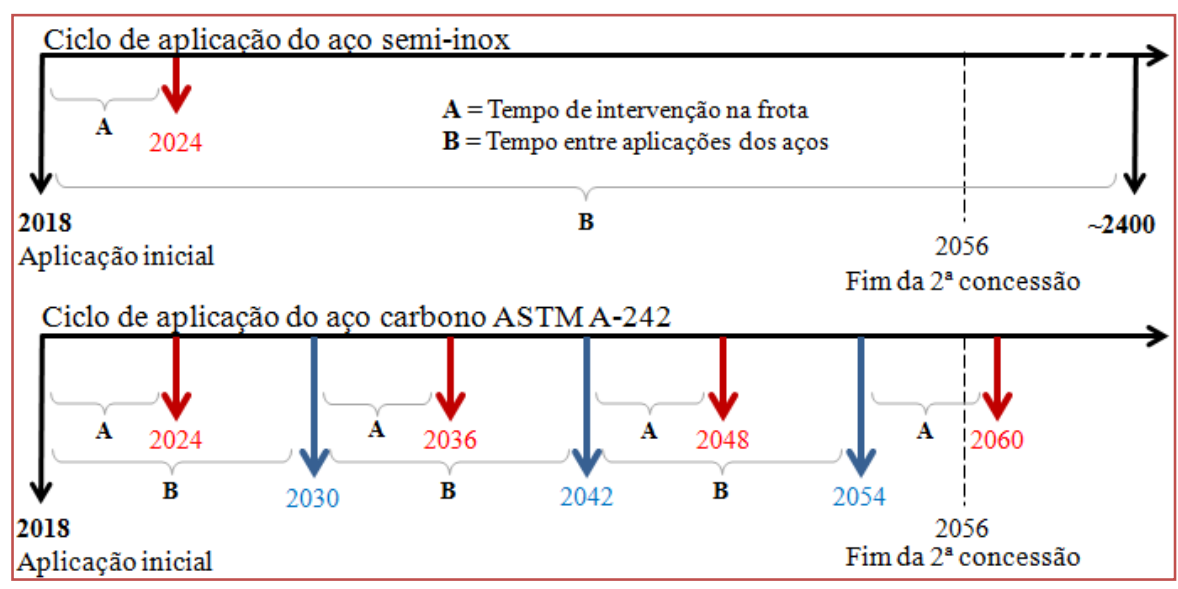

A tabela 5 permite verificar que para um cenário de fim da 1a concessão da empresa, o aço ASTM A-242, mesmo não recomendado para esse tipo de operação, traz um LCC satisfatório comparado ao aço semiinox, entretanto, ao analisar um cenário de fim de uma possível $2^{\underline{a}}$ concessão o aço semi-inox se faz mais econômico ao longo da vida útil do ativo.

Tabela 5: Cálculo do custo do ciclo de vida (LCC)

\begin{tabular}{|c|c|c|c|c|}
\hline \multirow[b]{2}{*}{ Custo das chapas laterais } & \multicolumn{2}{|c|}{ ASTM A-242 } & \multicolumn{2}{|c|}{ Semi inox 410D } \\
\hline & $\mathrm{RS}$ & $2.367,40$ & RS & $4.828,09$ \\
\hline Custo das chapas de assoalho & $\mathrm{RS}$ & $3.222,08$ & RS & $7.333,35$ \\
\hline Custo das chapas de cabeceira & $\mathrm{R} S$ & 783,20 & RS & $1.597,26$ \\
\hline Custo com Hxh de metalurgico para cabeceiras e laterais & $\mathrm{RS}$ & $2.472,07$ & $\mathrm{R} S$ & $2.472,07$ \\
\hline Custo com Hxh de metalurgico para assoalho & $\mathrm{RS}$ & $2.357,09$ & RS & $2.357,09$ \\
\hline Custo dos insumos para assoalho (gases, arames, discos) & $\mathrm{R} S$ & 646,11 & RS & $2.809,11$ \\
\hline Custo dos insumos para cabeceiras e laterais & $\mathrm{RS}$ & $1.021,29$ & RS & $4.420,29$ \\
\hline Custo de aplicação inicial (vida util ao final da $1^{\mathrm{a}}$ concessão) & RS & $12.869,25$ & RS & $25.817,26$ \\
\hline Quantidade de intervenções ao final da $2^{\mathrm{a}}$ concessão (2056) & & $4^{*}$ & & 1 \\
\hline Custo de aplicação ao final da $2^{a}$ concessão & RS & $39.026,42$ & RS & $25.817,26$ \\
\hline 5.015 Vagões & RS & $717.480,25$ & RS & $473.566,92$ \\
\hline
\end{tabular}

\section{CONCLUSÕES E RECOMENDAÇÕES}

Foi possível verificar com esse estudo que o comportamento visto no ensaio de polarização, com os parâmetros de Tafel, foi validado pelas medições de espessura realizadas em campo e a classificação de corrosividade indicada pela norma NACE pode ser adotada como premissa de projeto para novos ativos. Outra constatação importante, oriunda dos ensaios, é a de que o aço ASTM A-242 possui melhor desempenho comparado ao aço patinável da frota estudada.

Os cenários de LCC apresentados na tabela 5 possuem significativa relevância e podem servir de base para tomada de decisão sobre a melhor alternativa de intervenção da frota de vagões estudada, dado que para um marco de final da $1^{\mathfrak{a}}$ concessão a opção do aço carbono possui vantagem financeira, porém, para uma possível renovação de concessão, o aço semi-inox se torna a melhor alternativa financeira e com menor impacto operacional devido à sua necessidade de aplicação em uma única vez.

Recomenda-se para tomada de decisão final, a realização de um comparativo utilizando o método VPL (Valor Presente Líquido) adotando a taxa utilizada pela empresa, levando em conta o benefício secundário de menor carry back (peso morto residual após descarga do material) observado nos protótipos de vagões GDT que possuem chapas de aço semi-inox, que resultaram, em média, numa primeira avaliação, $640 \mathrm{~kg}$ a menos, comparados aos vagões dotados da chapa de aço carbono. Essa menor retenção de peso pode 
influenciar positivamente no consumo de combustível do trem quando circulando em vazio, viabilizando ainda mais essa opção.

\section{REFERÊNCIAS}

[1] ALVES, Maria Bernardete M.; ARRUDA, Susana M. Como Fazer referências: bibliográficas, eletrônicas e demais formas de documentos. Santa Catarina: UFSC, 2007, 21p.

[2] CALLISTER JR., Willian D, RETHWISCH, David G. Ciência e engenharia de materiais uma Introdução. 8 edição. Rio de Janeiro, LTC, 2012.

[3] CASTRO, Carmen. Metodologia da pesquisa científica. 03-07 de Out de 2016.54 p. Notas de Aula.

[4] CHIAVERINI, Vicente. Tecnologia mecânica. 2. Ed. - São Paulo : McGrawHill, 1986.

[5] ENGENHARIA DE MATERIAL RODANTE. Coordenação de Engenharia e Desenvolvimento. Relatório análise das trincas em caixas de vagões. Juiz de Fora. 2016. Relatório em Power point.

[6] ENGENHARIA DE MATERIAL RODANTE. Gerência de Engenharia e Material Rodante. POP-ENG-1133 Procedimento operacional padrão preventiva VR1, VR2 e VR4 em vagões de todas as frotas. Juiz de Fora. 2016. 77 p.

[7] Flanagan, R., G. Norman, J. Meadows, e G. Robinson (1989), Life Cycle Costing Theory and Practice, BSP Professional Books: Oxford.

[8] Hansen, D., e M. Mowen (2005), Cost Management: Accounting and Control, 5a Edição, Ohio: Thomson South Western.

[9] LINS, Vanessa de Freitas Cunha; SOARES, Renata Braga; FARIA; Ricardo Adriano Dorledo de. Relatório técnico resistência à corrosão de diferentes tipos de aços em vagões expostos a água coletada de dreno. Minas Gerais: UFMG, 2017. $9 \mathrm{p}$.

[10] NACE RP-07-75. Standard recommended practice, preparation, installation, analysis and interpretation of corrosion coupons in oilfield operations, 1999.

[11] NACE TM 01-69. Standard guide for laboratory immersion corrosion testing of metals, 2012. p. 10.

[12] NUNES, Laerce de Paula. Fundamentos de resistência à corrosão. , - Rio de Janeiro: Interciência: IBP: ABRACO, 2007.

[13] Woodward, D. (1997), "Life Cycle costing - theory, information acquisition and application", International Journal of Project Management, Vol.15, № 6, pp. 335-344. 


\section{Capítulo 12}

\section{Análise de tensões geradas no contato roda/trilho através de simulações numéricas}

\section{Rafael Soares Cardoso \\ Mateus Fortes Carvalho \\ Kamila da Silva Pompeu \\ Leonardo Dantas Rodrigues}

Resumo: Cátedras são instâncias acadêmicas destinadas a ensinar e investigar um tema de forma permanente. Em prática, a Cátedra Roda-Trilho foi criada em 2014 a partir de um convênio firmado pela Vale. 0 projeto tem por objetivo buscar melhorias de performance nas interações roda-trilho, uma vez que apenas nas Estradas de Ferro Carajás (EFC) são feitas 5 mil a 6 mil soldas aluminotérmicas anualmente e UFPA é uma das várias universidades envolvidas. Com um projeto liderado pelo professor José Maria do Vale Quaresma, responsável pelo Estudo de Defeitos em Trilhos, o grupo Núcleo de Análise Avançadas de Tensões (NAAT) da UFPA apresenta neste artigo uma contribuição para o entender do comportamento das distribuições de tensões de contato na interação Roda-Trilho por meio analítico e método de elementos finitos utilizando o software ANSYS.

Palavras-chave: Tensões de contato, roda-trilho, Tensões de Hertz. 


\section{INTRODUÇÃO}

A região Norte possui uma linha ferroviária de $1560 \mathrm{~km}$ de extensão, conforme a ANTT, dos quais $815 \mathrm{~km}$ foram construídas e/ou são operadas e utilizadas pela Vale do Rio Doce para escoar sua produção. Essas linhas possuem uma grande diversidade de condições operacionais, de fabricação e de manutenção.

A alta eficiência energética no transporte ferroviário só é possível devido às baixas perdas de energia no contato de rolamento entre as superfícies duras da roda e do trilho, que se tocam apenas em uma pequena área de contato (LEWIS, 2009). Em decorrência disso, elevadas tensões são observadas no contato (Ihha, 2001) e vários fenômenos indesejados ocorrem.

Segundo (Vínicius, 2017), por depender de uma gama de fatores, as tensões no contato apresentam diferentes magnitudes e variações. De modo que associadas a fatores metalúrgicos e operacionais, resultam em diferentes mecanismos de degradação, que alteram a geometria, as propriedades mecânicas e causa remoção de material do par roda-trilho, sendo então o principal causador de defeitos nos trilhos.

Dentro desse contexto, a Mineradora Vale em parceria com Instituições de Ciência e Tecnologia brasileiras criaram o Cátedra Roda-Trilho em 2014. A iniciativa busca tornar o transporte de minério mais eficiente e seguro, por meio de estudos em metalurgia, mecânica do contato, dinâmica do vagão, geometria e esforços na via permanente, superestrutura da via permanente e gestão do contato. Esperando que o conhecimento adquirido se traduza em melhorias na segurança dos veículos, no aumento da durabilidade das vias permanentes, parâmetros relevantes para a competitividade dos serviços de logística da Vale.

A Universidade Federal do Pará (UFPA) é uma das várias parceiras envolvidas nos trabalhos, e em um dos projetos liderado pelo professor José Maria do Vale Quaresma é responsável pelo Estudo de Defeitos em Trilhos.

Como forma de contribuir com os estudos, o grupo Núcleo de Análise Avançado de Tensões (NAAT) da UFPA apresenta nesse artigo o desenvolvimento de modelos numéricos pelo método de elementos finitos, com a utilização do Software ANSYS $®$, que forneçam boas estimativas das tensões ocasionadas pelo contato roda/trilho. Primeiro foram desenvolvidos modelos simples para avaliação de tensões de contato que possuam soluções analíticas, por meio do software MATLAB $®$, permitindo validar os modelos numéricos. As condições de malha são primordiais quando se trabalha com tensões de contato, dados os enormes gradientes existentes, por isto essas comparações são muito relevantes.

\subsection{OBJETIVOS}

0 artigo em questão, se compromete em:

Gerar modelos numéricos com tensões de contato que tenham solução analítica para comparação e validação dos resultados.

Analisar as tensões geradas no contato roda/trilho através simulações numéricas.

\section{FUNDAMENTAÇÃO TEÓRICA}

O transporte ferroviário é um dos meios mais práticos, eficazes e econômicos para realizar o deslocamento de grandes volumes de carga. 0 Brasil como grande produtor de minérios possui três das maiores ferrovias do mundo e cerca de 28 mil quilômetros de ferrovias que interligam as várias regiões do País (ABIFER).

Os trilhos estão sujeitos a defeitos de fabricação que vão desde defeitos metalúrgicos até originados a partir da ação repetida de carregamento exercidos pelas rodas no trilho durante a passagem do trem. Esses defeitos afetam a integridade dos trilhos ferroviários, já que aumentam os riscos de falhas que podem ocasionar acidentes (Schneider, 2005).

Entre os estudos sobre defeitos em trilhos, particular foco tem sido dado a um defeito transversal interno chamado de trinca transversal de fadiga (detail fracture) porque este é o defeito de fadiga mais comum encontrado em linhas continuamente soldadas. Este é um defeito sério, pois provoca a fratura com a passagem do trem, podendo assim ocasionar um descarrilamento do mesmo (Jeong, 2001). 


\subsection{TENSÕES DE CONTATO}

As tensões introduzidas nos materiais em contato em uma situação de rolamento são altamente dependentes da geometria das superfícies em contato, bem como do carregamento e das propriedades do material. No caso geral, é permitida qualquer geometria tridimensional em cada membro em contato e, como é de se esperar, seus cálculos são muito complexos. Duas geometrias especiais de interesse prático são, até certo modo, mais simples de serem analisadas. Elas são esfera contra esfera e cilindro contra cilindro. Em todos os casos, os raios de curvatura das superfícies em contato são fatores significativos (Robert L. Norton, 2013).

A primeira teoria desenvolvida para explicar o fenômeno de contato entre dois corpos foi apresentada por Hertz, no fim do século passado (Johnson, 1985).

0 modelo de Hertz postula que quando dois sólidos são postos em contato, eles inicialmente se tocam em um ponto (para contato entre duas esferas) ou ao longo de uma linha (para contato entre cilindro). Hertz também relaciona o crescimento da área de contato com a intensidade do carregamento aplicado entre os sólidos, se deformando ao redor do ponto inicial de contato (Fig. 1). Dessa maneira, o conhecimento das formas da área de contato é de extrema importância para determinar as tensões que atuam no contato.

Figura 1. (a) Distribuição da pressão elipsoidal para contato esférico. (b) Distribuição da pressão elipsoidal para contato cilíndrico.

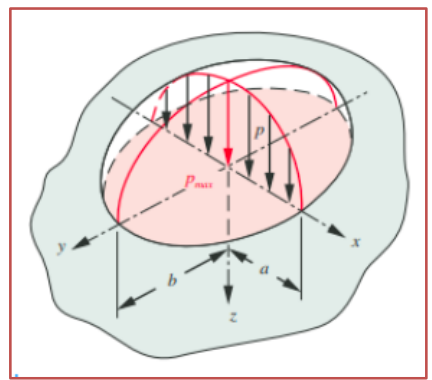

(a)

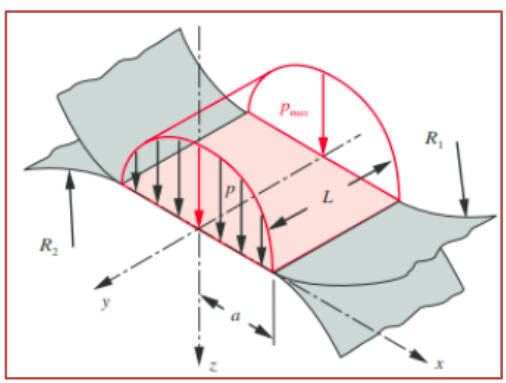

(b)

Pode-se confinar a atenção àquela parte de cada corpo muito próxima do contato, já que, ali, as tensões são muito maiores que as que ocorrem em qualquer outra parte. Para prevenir a possibilidade de falha da superfície, nesses casos, é necessário calcular e compreender os estados de tensão que resultam do carregamento de um corpo sobre o outro (Écio N. Duarte, 2016).

\subsection{MÉTODOS DE ELEMENTOS FINITOS}

A simulação computacional é amplamente utilizada nas empresas para realizar análises e melhorar a qualidade dos produtos e projetos. Grande parte dessas análises é realizada por meio de softwares que utilizam o Método dos Elementos Finitos, os quais possibilitam a obtenção de respostas para inúmeros problemas de engenharia.

A geometria submetida aos carregamentos e restrições é subdividida em pequenas partes, denominadas de elementos, os quais passam a representar o domínio contínuo do problema. A divisão da geometria em pequenos elementos permite resolver um problema complexo, subdividindo-o em problemas mais simples, o que possibilita ao computador realizar com eficiência estas tarefas.

0 método propõe que o número infinito de variáveis desconhecidas, sejam substituídas por um número limitado de elementos de comportamento bem definido. Essas divisões podem apresentar diferentes formas, tais como a triangular, quadrilateral, entre outras, em função do tipo e da dimensão do problema. Como são elementos de dimensões finitas, são chamados de "elementos finitos" - termo que nomeia o método.

Os elementos finitos são conectados entre si por pontos, os quais são denominados de nós ou pontos nodais. Ao conjunto de todos esses itens - elementos e nós - dá-se o nome de malha. Em função dessas subdivisões da geometria, as equações matemáticas que regem o comportamento físico não serão resolvidas de maneira exata, mas de forma aproximada por este método numérico. A precisão do Método 
dos Elementos Finitos depende da quantidade de nós e elementos, do tamanho e dos tipos de elementos da malha. Ou seja, quanto menor for o tamanho e maior for o número deles em uma determinada malha, maior a precisão nos resultados da análise.

\section{ESTUDOS DE CASO}

\subsection{CONTATO ENTRE ESFERAS}

Para o programa do cálculo analítico das tensões, primeiramente, foi realizado o estudo e desenvolvimento de modelos de tensões de contato conhecidos, foi utilizado o contato entre esferas, com base nos conhecimentos e formulações propostas por Heinrich Hertz. O estudo destes contatos mais simples possibilita um entendimento melhor do comportamento das tensões de contato de modo que seja possível evoluir para a análise de contato entre roda e trilho.

Os primeiros modelos de contato entre esferas foram gerados com base em um caso específico: duas esferas com 0,05 m de diâmetro e módulo de elasticidade de $200 \mathrm{GPa}$, ambas, e sendo pressionadas entre si por uma força de $50 \mathrm{~N}$. 0 progresso do estudo se deu pela análise dos cálculos analíticos das tensões de contato com embasamento na literatura e adaptado para a automatização dos resultados com o auxílio do software MATLAB 2016. Além disso, foi montado um código de forma que fornecesse a máxima tensão de contato entre as esferas e a distribuição ao longo do material, em conjunto com a área de contato e um gráfico que ilustre essas informações.

A figura 2 mostra o resultado para as tensões de Hertz e tensões cisalhante calculadas analiticamente por meio do programa para este caso específico, a tensão máxima de compressão atingida foi de 916 MPa.

Figura 2. Distribuições das tensões de hertz na região de contato.

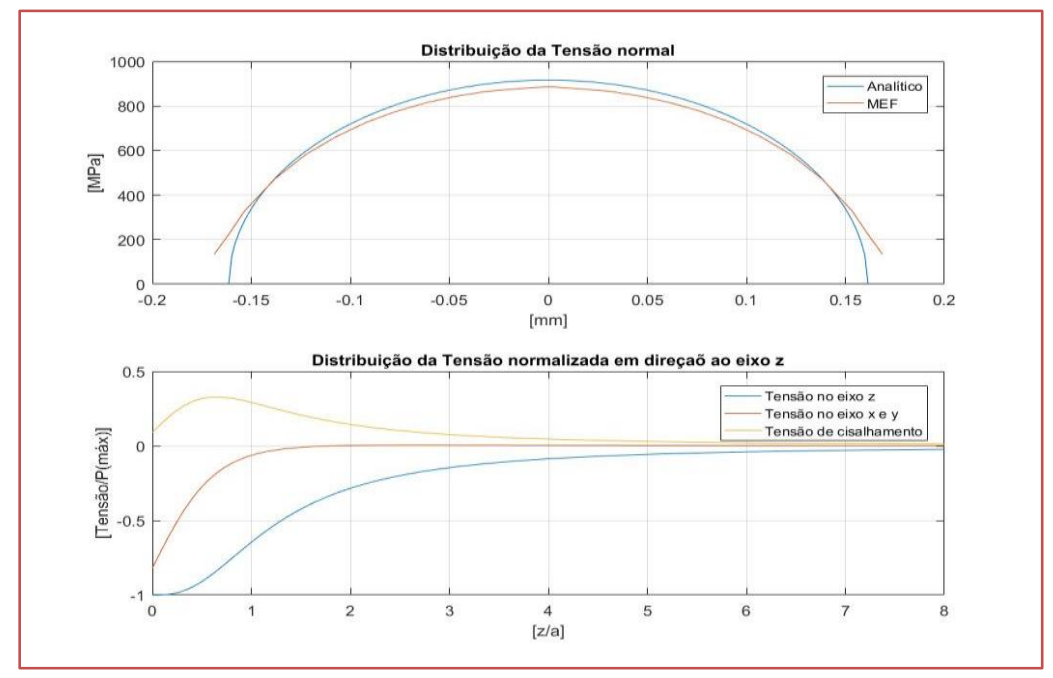

No modelo numérico, apenas um quarto de cada esfera foi desenhado e condições de contorno que fizessem a estrutura se comportar de forma simétrica foram aplicadas, as esferas também têm 0,05 $\mathrm{m}$ de diâmetro. 0 material das esferas tem as mesmas propriedades mecânicas do material utilizado para o cálculo analítico.

Para a malha foi utilizado o recurso sizing na configuração sphere of influence, essa condição foi aplicada nos polos da esfera em contato, o tamanho da esfera foi de $1 \mathrm{~mm}$ e o tamanho do elemento foi de $0,01 \mathrm{~mm}$.

Nas condições de contorno, foram aplicados frictionless supports às faces de simetria da esfera, restrição de deslocamento igual a zero no polo inferior da esfera inferior e uma força de $12,5 \mathrm{~N}$ orientada no sentido de um polo a outro foi aplicado no polo superior da esfera superior. A figura 3, mostra o resultado da simulação com as condições descritas e a figura 2, demostra os valores das tensões compressivas pelo metodo dos elementos finitos comparando ao analítico, dessa forma é possível notar que os valores encontrados foram próximos. 
Figura 3. A) Ilustração da distribuição de tensão compressiva na área de contato. B) Ilustração das tensões compressivas ao longo do material.

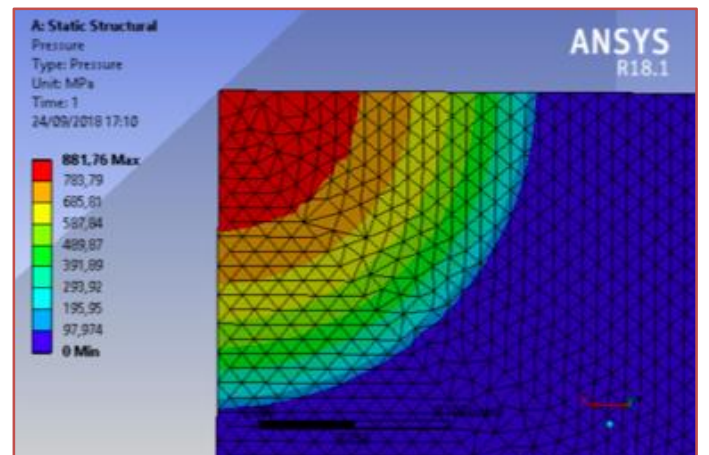

(a)

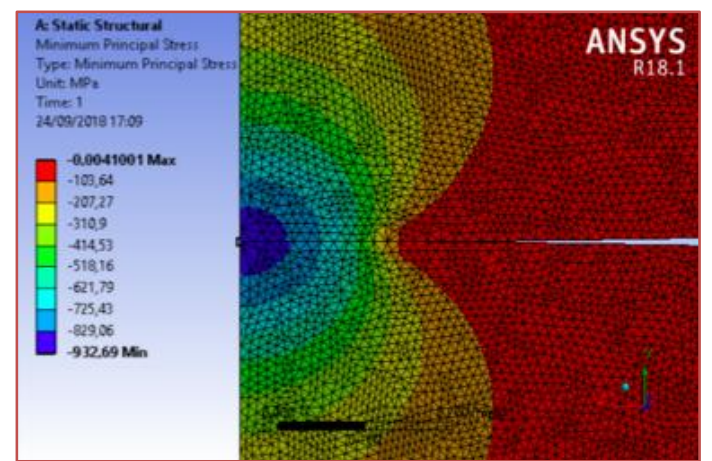

(b)

\subsection{CONTATO RODA TRILHO}

Para os modelos de contato roda trilho desenvolvidos em ANSYS foi utilizado o perfil TR 68. Foram desenvolvidos dois casos: roda sobre um dormente e roda entre dormentes, ambas sem inclinação.

A geometria da roda e do trilho foi feita no software SolidWorks $®$, o trilho foi dividido em quatro partes para que fosse mais fácil de criar uma malha mais refinada nos locais onde há o contato entre roda e trilho.

Para o contato entre roda e trilho foi adotado um coeficiente de atrito de 0,5 o mesmo utilizado por (ZHAO et al, 2016). Como a análise de contato é não linear, o comportamento foi escolhido como assimétrico, o método para o controle de passos no tempo foi a bisseção automática e a região de penetração foi determinada que não deveria ser maior que $1 \mathrm{~mm}$.

A malha foi refinada de modo que a região de contato entre a roda e o trilho tivesse um tamanho de elemento de $0,0005 \mathrm{~m}$ e o tipo de elemento utilizado foi o SOLID 187, tetraédrico de 10 nós. Devido a limitações de hardware, a malha foi feita de modo que o número de nós fosse sempre inferior a duzentos mil nós.

As condições de contorno foram frictionless supports nas faces longitudinais de simetria do trilho, fixed supports em sua base, na roda foram colocadas restrições de modo que a mesma só pudesse se mover verticalmente e, no centro da roda, foi adicionada uma força com a mesma magnitude que se espera no carregamento de uma roda que transporta minério.

Na parte das configurações de análise foi utilizada a configuração automática de subpassos no tempo, sendo o número mínimo de passos igual a vinte e o número máximo igual a cem, as grandes deformações foram ligadas e nos controles não lineares foi utilizado método de Newton-Raphson não simétrico. A figura 4, mostra uma representação do trilho, posição e orientação cartesiana do contato roda-trilho que será abordado a seguir.

Figura 4. Representação de posição e orientação do contato roda-trilho.

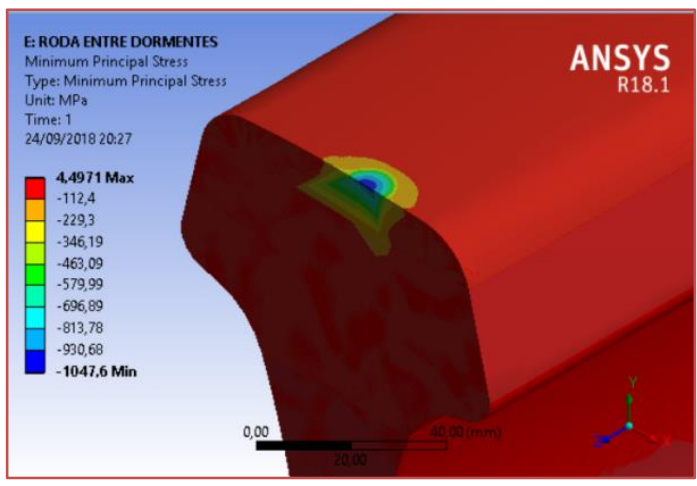




\subsection{RODA SOBRE DORMENTE E SEM INCLINAÇÃO}

Neste caso foi utilizada metade da roda e do trilho, de modo que se pudesse dar um foco na área de contato, condições de simetria foram aplicadas. A malha apresentou um total de 114256 nós e 59239 elementos.

O tempo decorrido durante a simulação foi de 4842 s, a memória alocada foi de 7595 MB.

A figura 5 mostrada os valores de tensão compressiva obtidos para este caso específico entre o contato roda trilho. Na figura 6 são comparadas as tensões e é possível ver que os valores de tensão são bem parecidos com os valores encontrados por (ZHAO et al, 2016).

Figura 5. Gráficos da tensão de contato na direção x e y, respectivamente, do plano de contato, para a condição de roda sobre dormente.

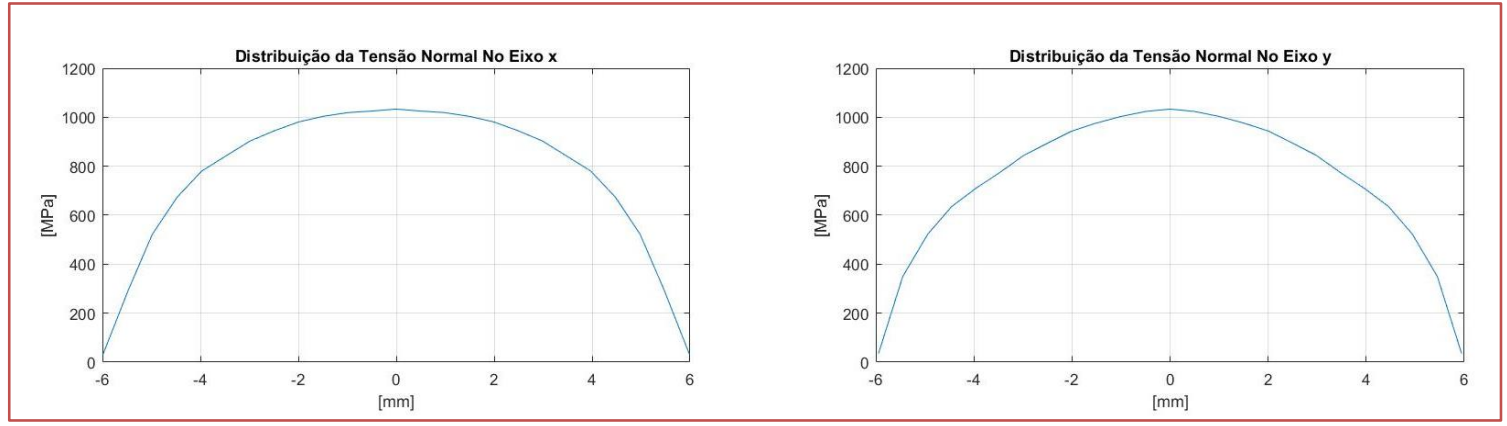

Figura 6. (a) Ilustração da distribuição das tensões de contato na superfície. (b) Pressão de contato estático e dinâmico (ZHAO et al, 2016).

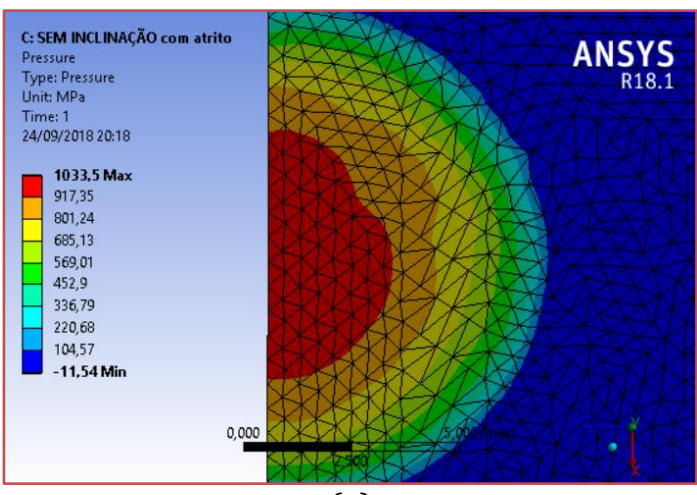

(a)

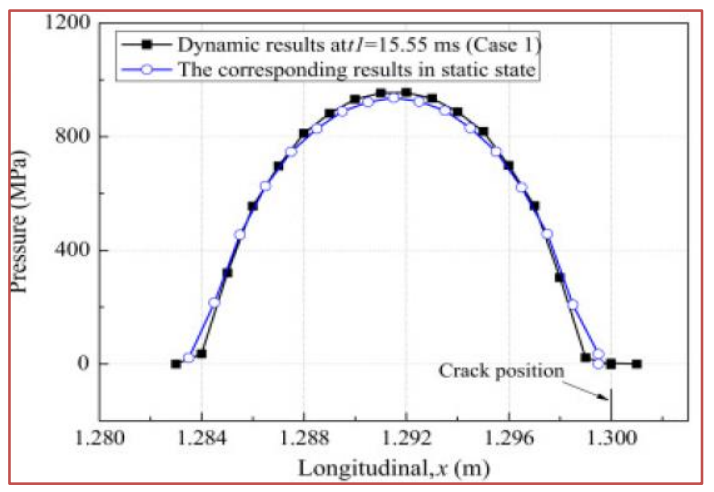

(b)

\subsection{RODA ENTRE DORMENTES E SEM INCLINAÇÃO}

Neste caso, o trilho foi desenhado do início do dormente até o espaço médio entre dois dormentes, sendo assim "meio trilho". Condições de simetria foram aplicadas à roda e ao trilho. A malha apresentou um total de 135979 nós e 71813 elementos. 0 tempo decorrido durante a simulação foi de 2791 s, a memória alocada foi de $8523 \mathrm{MB}$.

Na figura 6 são mostrados os valores de tensão compressiva obtidos para este caso específico entre o contato roda trilho. Novamente, nota-se que não houve uma alteração muito grande nas tensões de contato. 
Figura 7. Gráficos da tensão de contato na direção x e y, respectivamente, do plano de contato para a condição de roda entre dormentes.
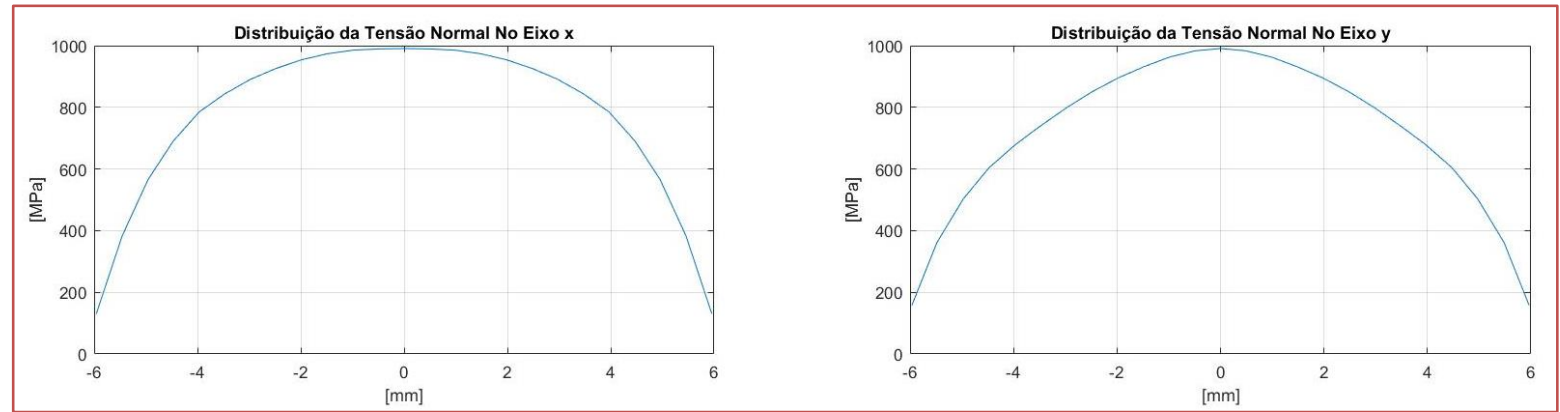

Figura 8. Ilustração da distribuição das tensões de contato na superfície.

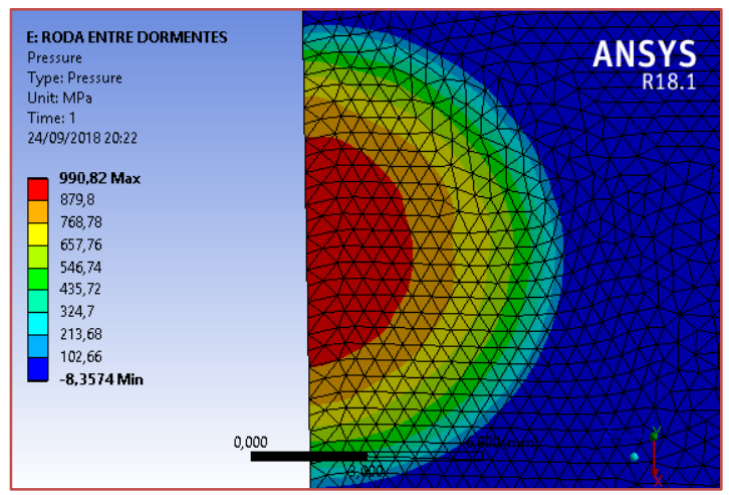

\section{CONCLUSÃO}

A determinação das tensões compressivas na superfície de contato por meio dos elementos finitos se mostrou bastante confiável. Na análise mais simples entre esferas, o gráfico da figura 2, reforça a similaridade dos resultados e o comportamento entre os dois métodos.

$\mathrm{Na}$ análise numérica aqui apresentada, foi realizado algumas modificações na geometria para a otimização do processamento e limitação do hardware. Dentro das condições de contorno e carregamento, a simulação apresentou compatibilidade satisfatória com os resultados de outros estudiosos. Isso mostra a viabilidade de tais modelos para o estudo posterior do surgimento de defeitos em trilhos.

Dessa forma, a compreensão do comportamento das tensões de contato no sistema roda-trilho é fundamental para o entendimento do surgimento de alguns defeitos superficiais em trilhos, surgimento de tricas e a quebra por fadiga.

A pesquisa do comportamento das tensões no sistema roda-trilho ainda irá continuar com novos desafios, mas fica a sugestão de novas análises para quem pretende pesquisar e conhecer mais:

Analisar o comportamento da tensão de cisalhamento ao longo do material do trilho pelo método dos elementos finitos.

Estudo da influência das tenções principais na propagação de trincas e rompimento por fadiga.

Análise dinâmica das tensões de contato na superfície de contato.

Os envolvidos direto ou indiretamente na pesquisa acreditam que o Cátedra Roda-Trilho é como uma via de mão dupla para a Universidade e a Empresa, que permite reter o conhecimento, aprofundá-lo e apresentar resultados, trazendo benefícios para ambos. 


\section{REFERÊNCIAS}

[1] Departamento Nacional de Infraestrutura de Transportes, DNIT. Disponível em: <http://www.dnit.gov.br/modais-2/ferrovias>. Acesso em: 06 de agosto de 2018.

[2] Agência Nacional de Transporte Terrestres, ANTT, 2016. Evolução Do Transporte Ferroviário De Cargas. Relatório elaborado com intermédio da SAFF.

[3] Associação Brasileira Da Indústria Ferroviária, ABIFER. Disponível em: <www.abifer.org.br/>. Acesso em: 03 abril 2018.

[4] COLPAERT, Hubertus. Metalografia dos Produtos Siderúrgicos Comuns. Editora Edgard Blücher. São Paulo, 1974.

[5] CVRD. Companhia Vale do Rio Doce. Manual de Defeitos em Trilhos Estrada de Ferro Carajás. Engenharia da Via Permanente - GAVIN, 2001.

[6] DUARTE, ÉCIO N., Mecânica Do Contato Entre Corpos Revestidos. Editora Edgard Blücher Ltda, 2016.

[7] IHHA - International Heavy Haul Association. Guidelines to best practices for heavy haul railway operations: wheel and rail interface issues. 1st edition, Virginia Beach, 2001.

[8] JEONG, D.Y., TANG, Y.H., ORRINGER, O. Estimation of Rail Wear Limits Based On Rail Strength Investigations. DOT/FRA/ORD-98/06, 1998.

[9] JEONG, D.Y., Progress in rail integrity research. DOT/FRA/ORD-01/18, 2001.

[10] JOHNSON, K. L. Contact Mechanics. Cambridge University Press, Cambridge, 1985.

[11] LEWIS, R.; OLOFSSON, U. Wheel-rail interface handbook. Woodhead Publishing, 1st Edition, 2009.

[12] Método Dos Elementos Finitos: O Que É?, ESSS. Disponível em: <https://www.esss.co/blog/ansys-discoverylive-simulacao-em-tempo-real/>. Acesso em: 03 abril 2018.

[13] NORTON, R. L., Projetos de Máquinas: Uma Abordagem Integrada. 4⿳亠丷厂 Edição, 2013.

[14] SCHNEIDER, Eduardo L., Análise Da Vida Remanescente De Trilhos Com Defeitos Transversais Desgastados Em Serviço. Dissertação de Mestrado, Universidade Federal Do Rio Grande Do Sul, 2005.

[15] ZHAO, X., ZHAO X., CHAO, L., WEN Z., JIN, X,. A study on dynamic stress intensity factors of rail cracks at high speeds by a 3D explicit finite element model of rolling contact. Wear, Elsevier, 2016, pp 60-70. 


\section{Capítulo 13}

\section{A influência do aumento da dureza na diminuição do desgaste em um sistema tribológico de pino-sobre- disco}

Claudio Victor da Silva e Silva

Beatriz Seabra Melo

Vinicius Silva dos Reis

Clóvis Iarlande Oliveira Santana

Emerson David Cavalcante Santos

José Maria do Vale Quaresma

Resumo: A parada ou as várias substituições de componentes das máquinas é causada principalmente pelo desgaste, o que acarreta no recrudescimento dos custos. Dessa forma, torna-se necessário pesquisar processos que diminuam a perda de massa por desgaste. 0 processo pino-sobre- disco é realizado com base no deslizamento das superfícies em contato. Nesse viés, tem-se uma carga fixa de $70 \mathrm{~N}$ sobre o pino de dureza $340 \mathrm{HV}$, a qual gera o efeito de atrito no disco, assim comparam-se os resultados de ensaios realizados em discos de 380 HV e 600 HV. A partir disso, analisa-se o desgaste em função da variação da dureza do disco em relação ao comportamento do coeficiente de atrito, da perda de massa, da medição de rugosidade, da microdureza e da caracterização das superfícies desgastadas. A metodologia seguiu a norma ASTM G-99. Ademais, as amostras utilizadas nos ensaios seguem o padrão SAE 4140 com 5 mm de diâmetro por 15 mm de comprimento para pinos de aço e o padrão SAE H13 com 76 mm de diâmetro por $4 \mathrm{~mm}$ de espessura para discos de aço. Portanto, os resultados obtidos demonstram que o aumento da dureza do disco condicionou a diminuição do coeficiente de atrito, a diminuição da perda de massa do pino e do disco e a redução da deformação plástica visualizadas nas imagens do MEV.

Palavras-chave: desgaste, tribologia, dureza, pino-sobre-disco. 


\section{INTRODUÇÃO}

O desgaste é um problema conhecido desde a antiguidade que ainda vem sendo enfrentado na idade contemporânea, principalmente, pela indústria. Tem como consequência a substituição de componentes e peças de engenharia. Além disso, caso não aconteça uma boa manutenção preditiva, também pode acarretar em falhas mecânicas dos componentes e, em especial, falhas tribológicas, estas podem prejudicar à linha de produção.

0 desgaste de superfícies produz altos custos de manutenção e de operação associados tanto à perda de massa, quanto à perda de energia e tempo. As utilizações de métodos de controle de desgaste adequados podem gerar à redução das perdas e contribuir para o aumento da vida útil dos componentes mecânicos. Essa serie de fatores garante maior confiabilidade e disponibilidade dos sistemas industriais, baseado em (VIÁFARA,2010).

A Figura 1 ilustra esquematicamente três situações de desgaste de componentes. Na primeira situação, o desgaste severo está começando já na fase inicial da operação, devido ao design mal sucedido. Na segunda situação, um estado de desgaste moderado é alcançado após um período de running-in onde seguidamente tem-se a atuação de um longo período com baixas taxas de desgaste até que as taxas lentamente procedem para um desgaste severo. Finalmente, na terceira situação, concepção bem sucedida, produziu condição de contato, o qual, depois de um curto running-in, resulta em um longo período de desgaste insignificante. A carga de contato repetido, em última instância resulta, no entanto, na falha por fadiga se encaminhando a um desgaste catastrófico (HOLMBERG, 2001).

Figura 1 - Diferentes mecanismos de desgaste e nível crítico de atrito pelo tempo. Fonte: HOLMBERG, 2001.

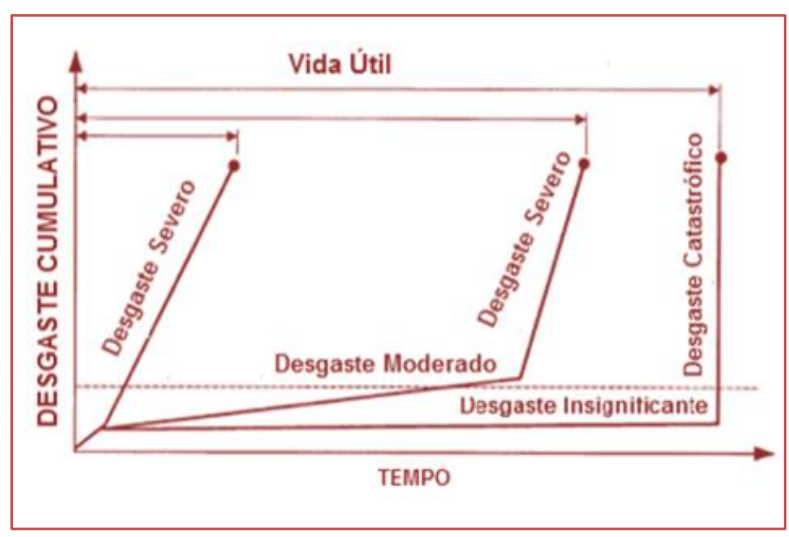

Ao determinar o comportamento do desgaste do material aborda-se como mitigar essa problemática do desgaste. Durante o uso de trabalho a quente, o desgaste do aço ferramenta é influenciado por vários parâmetros, tal quais a exposição do material a diferentes cargas e tensões, assim como o efeito do calor, da pressão, da corrosão e do deslizamento do material de trabalho. Isso exige do aço ferramenta boas propriedades mecânicas e anti-desgaste [1,2,3]. Ademais, o aumento da dureza do material da ferramenta é a abordagem mais comum com o objetivo de limitar ou melhorar a resistência ao desgaste [4].

Nessa conjectura, torna-se necessário conhecer, analisar e propor soluções aos fenômenos tribológicos através da quantificação de parâmetros e prevenção de falhas, por meio de analises laboratoriais objetivando o maior desenvolvimento dos sistemas mecânicos na indústria. Dessa maneira, este trabalho analisará a influência do aumento da dureza na diminuição do desgaste, com base no sistema pino-disco.

\section{MATERIAIS E MÉTODOS}

Os materiais utilizados para a aquisição de dados deste trabalho foram:

- Dois pinos de aço ABNT 4140 de $340 \mathrm{HV}$

- Dois discos de aço ABNT H13, sendo um de 380 HV e outro de 600 HV

- Tribômetro 
- Macrodurômetro

- Balança de precisão

- Microdurômetro

- Microscópio Eletrônico de Varredura (MEV)

- Rugosímetro

O fluxograma da figura 2 apresenta a metodologia utilizada para a execução deste trabalho.

Figura 2 - Metodologia utilizada para execução do trabalho.

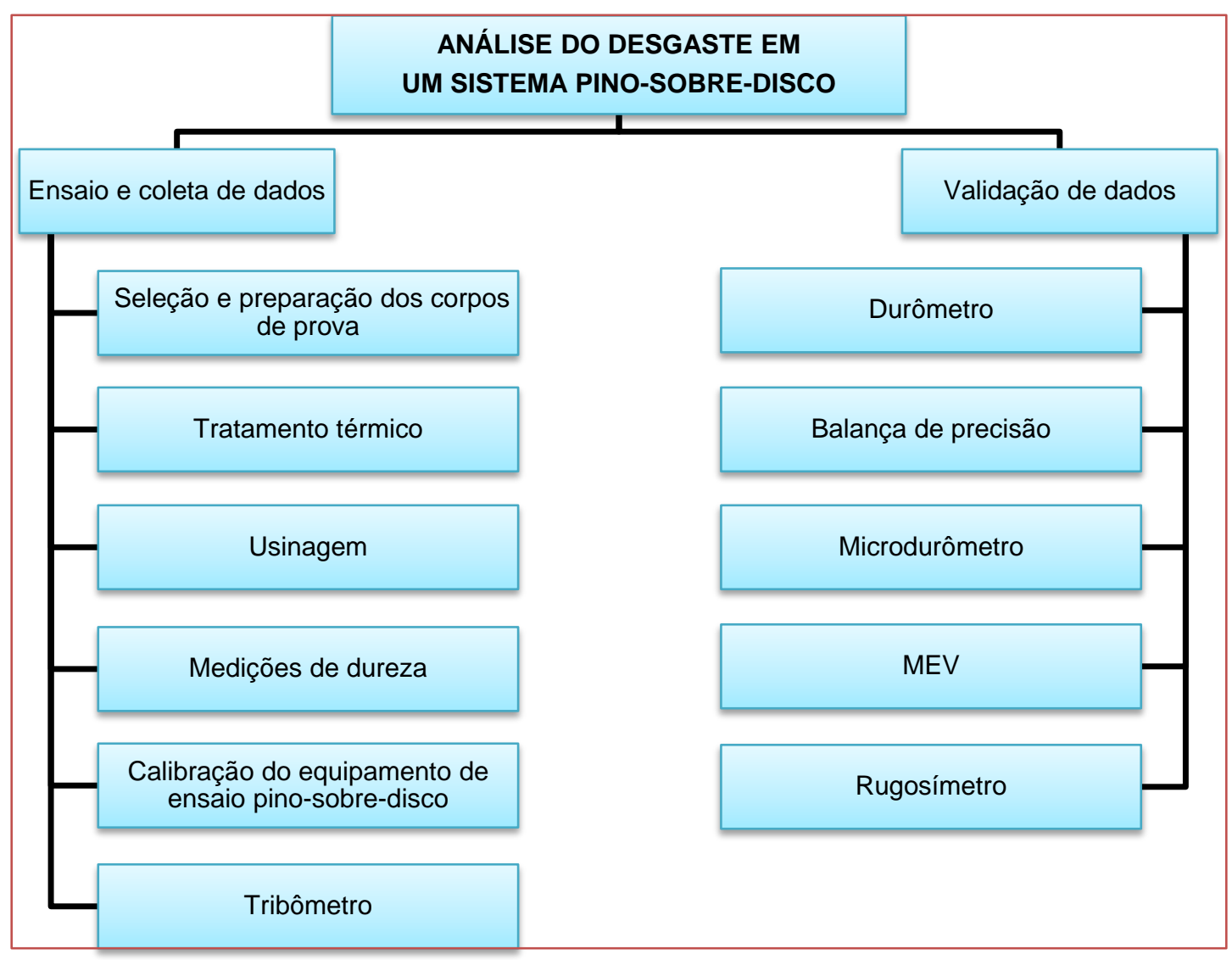

Os corpos de prova utilizados foram pinos de aço ABNT 4140 de alta resistência, adquiridos na condição de temperado com dureza em torno de $440 \mathrm{HV}$, tornando-se necessário um tratamento térmico para a dureza média de $340 \mathrm{HV}$ ser atingida, com dimensões de $5 \mathrm{~mm}$ de diâmetro por $15 \mathrm{~mm}$ de comprimento e discos de aço ABNT H13, os quais foram submetidos a tratamento térmico de têmpera mais revenido, com austenitização em $1050^{\circ} \mathrm{C}$ por 1 hora, variando-se as temperaturas e os tempos de revenido para obter dois níveis dureza (380 e $600 \mathrm{HV}$ ), com dimensões de $76 \mathrm{~mm}$ de diâmetro por $4 \mathrm{~mm}$ de espessura. Após esses processos, os corpos de prova foram usinados e medições de dureza realizadas. 
Figura 3 - Disco e pino utilizados nos ensaios.

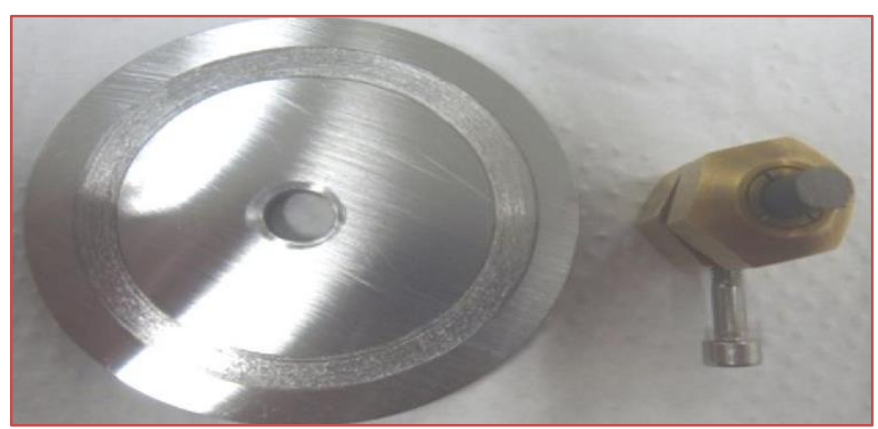

Os ensaios de desgaste por deslizamento foram realizados baseados na norma ASTM G-99 (G-99-90, 1992). O equipamento de ensaio pino-sobre-disco foi devidamente aferido e calibrado, e então foi realizada uma sequência de dez ensaios, sendo cinco ensaios para cada par pino x disco, mantendo a dureza dos pinos constante em $340 \mathrm{HV}$ e variando a dureza dos discos em $380 \mathrm{HV}$ e $600 \mathrm{HV}$.

Em seguida foi realizado ensaio de dureza nos pinos e discos em um no macrodurômetro digital Buehler. Além disso, foi utilizada uma balança especial com precisão de 0,00001 g utilizada para medir a massa de todas as amostras antes e depois do ensaio de deslizamento, com o objetivo de determinar a perda de massa dos pinos e discos.

As superficies de desgaste de pinos e discos foram caracterizadas primeiramente através da medição da microdureza por meio do microdurômetro digital, com carga de $50 \mathrm{~g}$, com objetivo de determinar o encruamento sofrido pelo ensaio por deslizamento. Segundamente, as amostras passaram pela análise das superfícies desgastadas no Microscópio Eletrônico de Varredura (MEV). Além disso, passaram pela medição de perfis e parâmetros de rugosidade da topografia em um rugosímetro, modelo Surftest SJ-301 da Mitutoyo.

\section{RESULTADOS E DISCUSSÃO}

\subsection{COEFICIENTE DE ATRITO}

As curvas de coeficiente de atrito vs. tempo de deslizamento foram determinadas para cada condição de ensaio de deslizamento. A Figura 4.1 (a) e (b) mostram curvas de coeficiente de atrito em função do tempo de deslizamento (900 e $1000 \mathrm{~s}$ ) para a carga normal de $70 \mathrm{~N}$ para as duas durezas de disco 380 e $600 \mathrm{HV}$, respectivamente.

Figura 4 - Curvas de coeficiente de atrito em função do tempo de deslizamento sob uma carga normal de $70 \mathrm{~N}$, com variação das durezas dos discos em (a) 380 e (b) $600 \mathrm{HV}$.

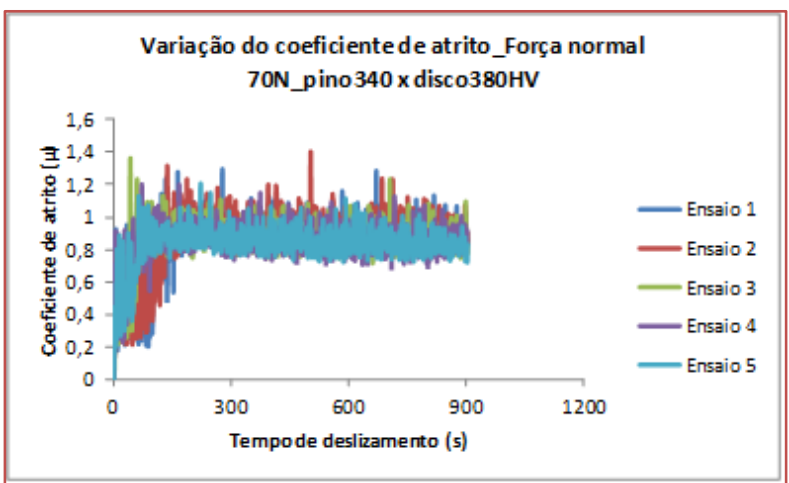

(a)

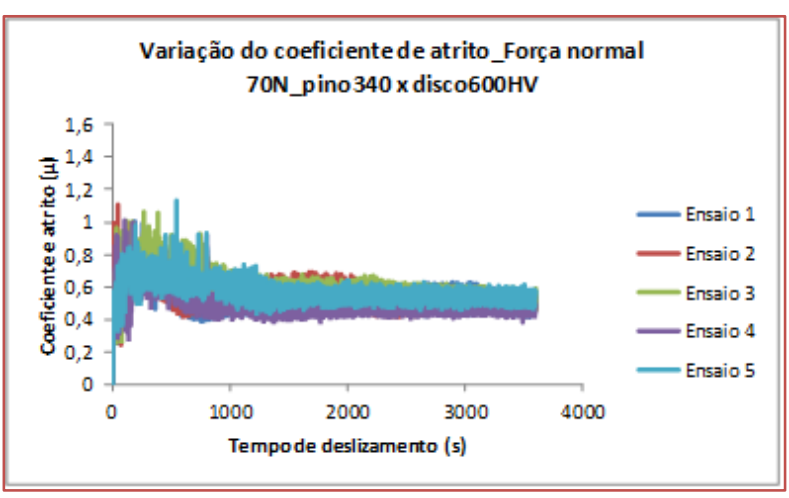

(b) 
No gráfico, da Figura 4(a), é mostrado os períodos de running-in e de regime permanente de atrito. 0 período do running-in ocorre nos primeiros $150 \mathrm{~s}$, no qual há um crescimento nos valores de coeficiente de atrito, chegando a acima de 1,0. Os valores de coeficiente de atrito variam em faixa constaste no gráfico, após o running-in, o que caracteriza o regime permanente de atrito.

Com o aumento da dureza do corpo mais duro (disco), o tempo de running-in aumenta para aproximadamente $220 \mathrm{~s}$ nas curvas do gráfico da Figura 4(b). Após o processo de running-in, os valores de coeficiente de atrito variam em faixa constante, abaixo dos valores do running-in, denotando regime permanente de atrito.

Os comportamentos mostrados nos gráficos anteriores podem ser explicados através da ocorrência dos mecanismos de desgaste, que promovem regimes diferenciados de desgaste. No período de running-in, o processo apresenta forte adesão das superfícies, gerando contato contínuo entre o pino e o disco, ocasionando deformação plástica no pino. Provavelmente, devido a este contato plástico, os óxidos são mais facilmente removidos do contato das superfícies, promovendo maiores valores de coeficiente de atrito. Após o amaciamento das superfícies, o regime de atrito torna-se permanente, com diferença significativa entre os discos estudados, ou seja, quando se aumentou a dureza do disco, o coeficiente de atrito diminuiu.

Nesse sentido, para os ensaios realizados para o disco de $380 \mathrm{HV}$ comparados ao disco de $600 \mathrm{HV}$, apresentam um maior coeficiente de atrito. Este fato não é benéfico para o aço ferramenta (H13), que em aplicação prática terá menor tempo de vida útil, devido ao aumento do coeficiente de atrito.

\subsection{DESGASTE}

0 efeito do desgaste nos corpos submetidos ao ensaio de deslizamento é representado pela medição de perda de massa dos pinos e discos desgastados. Nas Tabelas 1 e 2 encontram-se relacionadas os dados de perda de massa para cada condição e dureza de disco, assim como suas médias e desvios padrões. Para a carga normal de $70 \mathrm{~N}$ o tempo de deslizamento foi de $1800 \mathrm{~s}$ neste tempo houve um desgaste muito acentuado no ensaio 1 , o que contatou a interpretação da carga normal de $70 \mathrm{~N}$ ser muito alta, consequentemente, reduziu-se o tempo de deslizamento para $900 \mathrm{~s}$ para os outros quatro ensaios.

Tabela 1 - Resultados de perda de massa (mg/m) para os ensaios de pino $340 \mathrm{HV}$ x disco $380 \mathrm{HV}$

\begin{tabular}{|c|c|c|c|c|c|c|c|}
\multicolumn{7}{|c|}{ Perda de massa (mg/m) dos pinos (340 HV) e discos (380 HV) } \\
\hline Ensaios & 1 & 2 & 3 & 4 & 5 & Média & Desvio Padrão \\
\hline Pino & 5,17 & 5,19 & 5,79 & 7,75 & 5,48 & 5,48 & 0,29 \\
\hline Disco & 4,17 & 4,83 & 4,61 & 4,25 & 4,18 & 4,41 & 0,30 \\
\hline
\end{tabular}

Tabela 2 - Resultados de perda de massa (mg/m) para os ensaios de pino $340 \mathrm{HV}$ x disco $600 \mathrm{HV}$.

\begin{tabular}{|c|c|c|c|c|c|c|c|}
\multicolumn{7}{|c|}{ Perda de massa (mg/m) dos pinos (340 HV) e discos (600 HV) } \\
Ensaios & 1 & 2 & 3 & 4 & 5 & Média & Desvio Padrão \\
\hline Pino & 0,39 & 0,32 & 0,58 & 0,16 & 0,32 & 0,36 & 0,15 \\
\hline Disco & 0,23 & 0,18 & 0,20 & 0,07 & 0,08 & 0,15 & 0,07 \\
\hline
\end{tabular}

Nesse contexto, percebe-se que, analise das tabelas a respeito da perda de massa, evidencia que a perda de massa é maior para os discos de $380 \mathrm{HV}$ do que para disco de $600 \mathrm{HV}$. Com isso, mostrando a influência dureza sob a perda de massa. 


\subsection{ANÁLISE DAS SUPERFÍCIES DESGASTADAS}

As superfícies desgastadas dos pinos e discos foram caracterizadas em imagens obtidas através de Microscópio Eletrônico de Varredura (MEV). Foi selecionado um par pino x disco para cada condição de ensaio. Nessas imagens é possível perceber a mudança no comportamento do desgaste das superfícies, quando se aumenta a dureza do disco (corpo mais duro).

Figura 5 - Imagens do MEV das superfícies desgastadas do pino para (a) no ensaio de $380 \mathrm{HV}$ e (b) no ensaio de $600 \mathrm{HV}$.

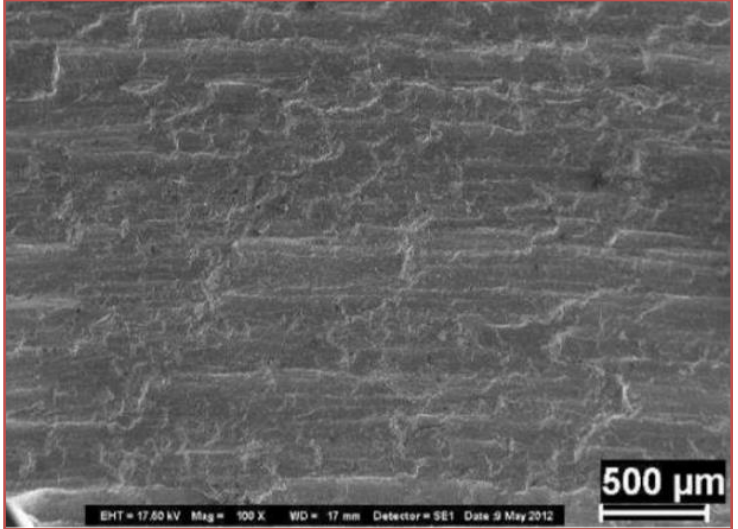

(a)

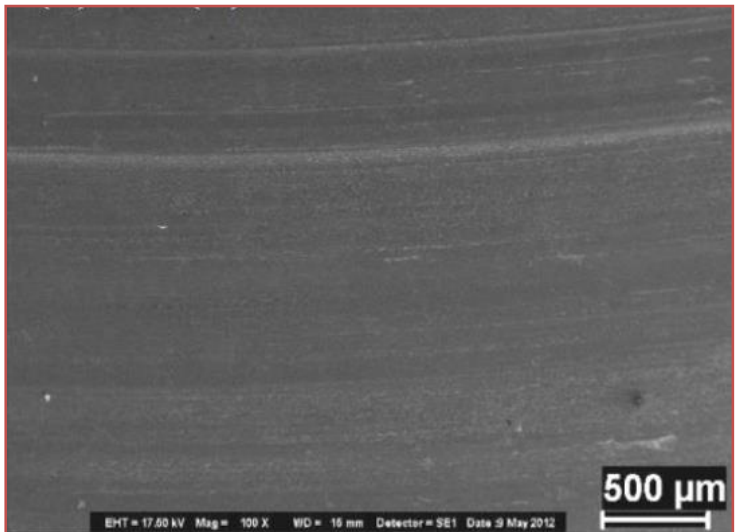

(b)

Na Figura 5 mostra imagens do MEV do pino, após o desgaste com carga normal de $70 \mathrm{~N}$ para um tempo de $900 \mathrm{~s}$, no caso do deslizamento do pino no disco de $380 \mathrm{HV}$, já para o disco de $600 \mathrm{HV}$ o pino deslizou no tempo de $1000 \mathrm{~s}$. Nesse viés, a análise das ampliações de $500 \mu \mathrm{m}$, ambas em modo elétrons secundários (es), possibilita inferir que na Figura 5(a) o pino apresentou maior deformação plástica se comparado ao pino da Figura 5(b).

Figura 6 - Comparação das micrografias do MEV das superfícies desgastadas. Disco 380 HV (a) e Disco 600 HV (b) ensaiados com carga normal $70 \mathrm{~N}$ (modo elétrons secundários).

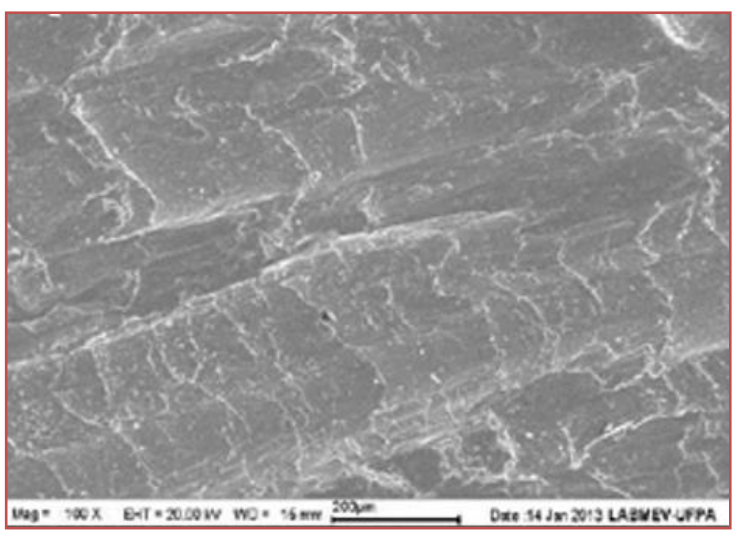

(a)

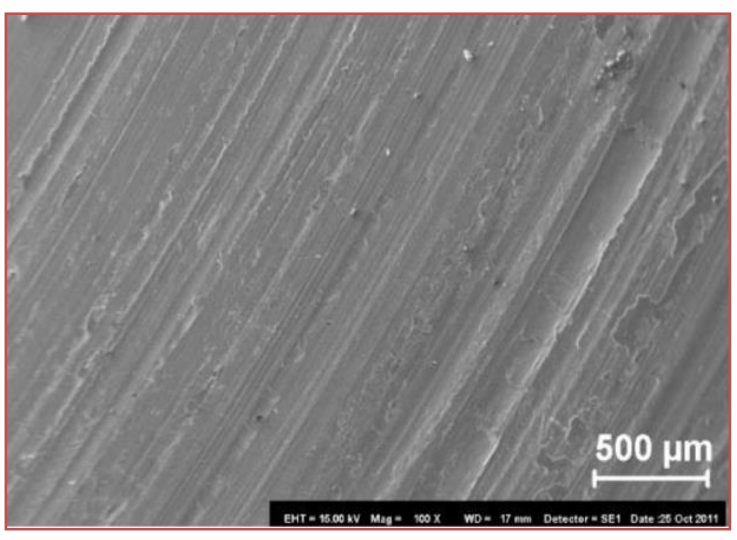

(b)

Foram destacadas duas micrografias, ambas em modo elétrons secundários (es) para uma carga de $70 \mathrm{~N}$ (disco 380 HV e disco 600 HV) na Figura 6. As micrografias (a) e (b) são discos ensaiados com carga normal $70 \mathrm{~N}$, onde se podem observar fortes marcas de deformação plástica, típicas de mecanismo severo de desgaste, criando marcas de desgaste acentuadas no disco. Apenas com a mudança da dureza do disco há a mudança do mecanismo de desgaste. 
O aumento na dureza do disco de $380 \mathrm{HV}$ para $600 \mathrm{HV}$, considerando a mesma dureza do pino (340 HV), provocou mudança significativa no mecanismo de desgaste (de adesivo para oxidativo), modificando as características das superfícies de desgaste.

\subsection{ANÁLISE DOS PARÂMETROS E PERFIS DE RUGOSIDADE DAS SUPERFÍCIES DESGASTADAS}

A Tabela 3 apresenta os valores médios dos parâmetros de rugosidade para as condições de ensaio com carga normal aplicada de $70 \mathrm{~N}$. Com isso, os parâmetros foram estudados e selecionados por apresentarem maior variação, o que os tornam mais representativos para analisar a condição de topografia superficial das amostras. $\mathrm{Rq}$ foi selecionado por ter maior sensibilidade que $\mathrm{Ra}$ aos grandes desvios na linha média. 0 Rv é importante, já que as modificações na topografia são mais relacionadas com o crescimento dos vales do que com os picos. Por fim, o Rsk é representativo na tendência da superfície apresentar picos removidos e vales profundos. Rdq representou as variações nas superfícies relacionadas com a inclinação do perfil (VIÁFARA, 2010).

Tabela 3 - Valores dos parâmetros de rugosidade para os pares pinos 340 HV x discos (380 HV e 600 HV).

\begin{tabular}{|c|c|c|c|c|c|}
\multicolumn{2}{|c}{ Ensaio } & Rq & Rv & \multicolumn{2}{c|}{ Rsk } \\
\hline \multirow{3}{*}{$\begin{array}{c}\text { Carga } \\
70 \mathrm{~N}\end{array}$} & Pino $340 \mathrm{HV}$ & $10,94 \pm 0,93$ & $21,31 \pm 1,70$ & $-0,01 \pm 0,06$ & $0,40 \pm 0,05$ \\
\cline { 2 - 6 } & Disco $380 \mathrm{HV}$ & $10,26 \pm 1,31$ & $20,88 \pm 3,17$ & $-0,16 \pm 0,12$ & $0,40 \pm 0,02$ \\
\cline { 2 - 6 } & Pino $340 \mathrm{HV}$ & $2,89 \pm 1,14$ & $6,34 \pm 2,94$ & $-0,08 \pm 0,23$ & $0,40 \pm 0,03$ \\
\cline { 2 - 6 } & Disco $600 \mathrm{HV}$ & $5,54 \pm 0,98$ & $11,83 \pm 1,50$ & $-0,29 \pm 0,12$ & $0,21 \pm 0,02$ \\
\hline
\end{tabular}

Na Figura 7 são apresentados os perfis de rugosidade das superfícies desgastadas, que confirmam o comportamento observado nos parâmetros de rugosidade.

Figura 7 - Perfis de rugosidade dos pinos e discos. (a) Pino 340 HV x (b) Disco 380 HV, (c) Pino 340 HV x (d) Disco $600 \mathrm{HV}$ para carga normal de $70 \mathrm{~N}$.

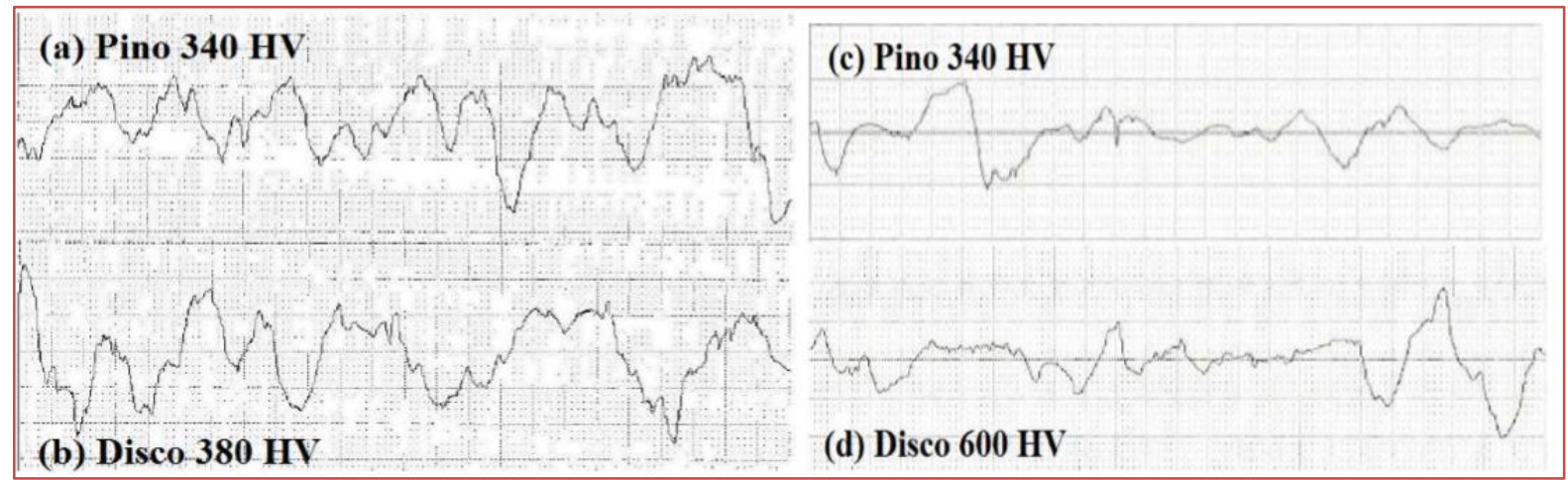

A análise da Tabela 3, evidencia que os valores para parâmetros de altura (Rq e Rv) são semelhantes entre os pinos e discos, e também, com características de rugosidade semelhantes para as duas superfícies. Isto pode ocorrer devido às durezas serem próximas ( $340 \mathrm{HV}$ para o pino e $380 \mathrm{HV}$ para o disco). 0 parâmetro Rsk, apresentou valores negativos para os ensaios (pino $340 \mathrm{HV}$ e disco $380 \mathrm{HV}$ ) estes valores representam a presença de vales profundos e picos removidos nas superfícies. Por fim, o parâmetro Rdq demonstrou valores próximos em todos os ensaios para o disco $380 \mathrm{HV}$, apresentados na Figura 7 (a) e (b).

Os perfis de rugosidade dos pinos e discos mostrados na Figura 7 (a) e (b) apresentam vales profundos e picos elevados, o que confirma os valores dos parâmetros mostrados na Tabela 3 . À medida que se aumenta a dureza, percebe-se a diminuição na amplitude das curvas para o pino $340 \mathrm{HV}$ e disco de 600 HV. 
A análise dos valores dos parâmetros obtidos para os ensaios com o disco de dureza 600 HV na Figura 7 (c) e (d), percebe-se um comportamento distinto das condições anteriores. Os valores dos parâmetros de altura (Rq e Rv) são diferentes para pinos e discos, sendo menores para os pinos. No entanto, os valores diminuíram bruscamente no disco de $600 \mathrm{HV}$ se comparados com o disco de $380 \mathrm{HV}$. Outrossim, observou-se que a inclinação dos picos (Rdq) diminuiu com o aumento da dureza do disco. Desse modo, comprova-se que quando a dureza é aumentada, em um par pino x disco, o mecanismo de desgaste é modificado e, consequentemente, alcançar-se superfícies menos rugosas.

\subsection{MEDIÇÕES DE MICRODUREZA}

A Figura 8 apresenta os gráficos de microdureza das superfícies desgastadas em função da carga normal aplicada para as durezas de $380 \mathrm{HV}$ e de $600 \mathrm{HV}$. Os valores de microdureza para a carga normal (zero) $0 \mathrm{~N}$, condizem aos resultados obtidos nas regiões não desgastadas das superfícies dos pinos e discos, assim pode-se comparar o quanto modificou a dureza após o desgaste.

Figura 8 - Gráfico de microdureza das superfícies do par pino 340 HV x disco 380 HV em função da carga normal $70 \mathrm{~N}$ (a), Gráfico de microdureza das superfícies do par pino 340 HV x disco $600 \mathrm{HV}$ em função da carga normal de $70 \mathrm{~N}$ (b).
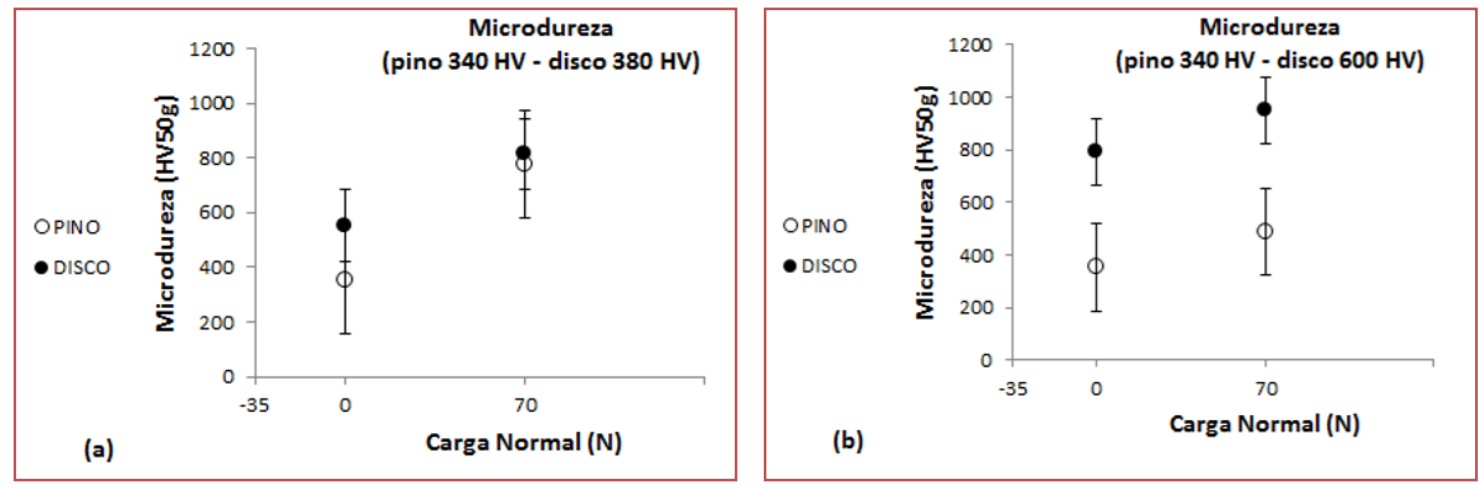

A análise da Figura 8 é possível constatar a diferença nos resultados da microdureza para os ensaios com o disco de 380 HV e de 600 HV. Para o primeiro disco, presente na Figura 8 (a) tem-se que os valores da microdureza são próximos para o pino e o disco na aplicação da carga de 70 N. Além disso, é notável que o disco possui maior microdureza em relação ao pino, em ambos os casos, por mais que este último tenha maior tido uma maior encruamento. A Figura 8 (b) apresenta os valores que os valores de microdureza dos pinos serão menores e a microdureza será maior para o disco de $600 \mathrm{HV}$, neste caso há uma diferença visível. É perceptível, que o pino para carga de $70 \mathrm{~N}$ terá maior encruamento na no ensaio com disco de $380 \mathrm{HV}$ do que no ensaio de disco de $600 \mathrm{HV}$.

\section{CONCLUSÃO}

As principais conclusões dos ensaios de desgaste por deslizamento realizados neste trabalho são sobre coeficiente de atrito, perda de massa, caracterização das superfícies desgastadas, rugosidade das superfícies desgastadas e microdureza.

\section{Coeficiente de atrito}

0 disco de $600 \mathrm{HV}$ por ser mais duro e ter um período de runnig-in maior que o disco de $380 \mathrm{HV}$, resulta em um deslizamento maior.

\section{Perda de massa}

Com o aumento da dureza do disco para $600 \mathrm{HV}$ ocorreu menor perda de massa em relação ao disco de dureza $380 \mathrm{HV}$. 


\section{Caracterização das superfícies desgastadas}

0 aumento da dureza do disco de $380 \mathrm{HV}$ para $600 \mathrm{HV}$, modificou as caraterísticas das superfícies de desgaste resultando em ser menos rugosa.

\section{Rugosidade das superfícies desgastadas}

Nota-se que com o aumento da dureza ocorre uma modificação no mecanismo de desgaste, e como consequência superfícies menos rugosas sendo alcançadas.

\section{Microdureza}

O aumento da dureza na mudança do disco ocasiona uma diminuição no valor da microdureza do pino, provocando menor índice de encruamento no disco.

\section{REFERÊNCIAS}

[1] ABNT NBR ISO 4287, Especificações geométricas do produto (GPS) - Rugosidade: método do perfil - Termos, definições e parâmetros de rugosidade. ABNT, 2002.

[2] LEITE, M.V. Conformação mecânica: efeito da topografia na transferência de material e no atrito. 2010, 148p. Tese (Doutorado em Engenharia Mecânica de Projeto e Conformação). Escola Politécnica da USP, São Paulo.

[3] SANTOS, E.D. Efeito da dureza de um corpo mais duro no coeficiente de atrito na rugosidade da superfície e na Resistência ao desgaste de um par aço x aço em função da variação da carga normal. 2013, 85p. Dissertação (Mestrado em engenharia mecânica). Programa de pós-graduação em engenharia mecânica, Universidade Federal do Pará. Belém-PA.

[4] STOETERAU, R.L. Tribologia. Universidade Federal de Santa Catarina - Santa TOMANIK, E. - Modelamento do desgaste por deslizamento em anéis de pistão de motores de combustão interna. 2000, 213p. Tese de Doutorado apresentada a Escola Politécnica da Universidade de São Paulo, para obtenção do título de Doutor em Engenharia, São Paulo.

[5] VIÁFARA, C.C., Sinátora, A. Influence of hardness of the harder body on wear regime transition in a sliding pair of steels. Wear, vol. 267, p. 425-432, 2009.

[6] VIÁFARA, C.C., Sinátora, A.The effect of hardness of sliding bodies on the wear regime transition of steels. First International Brazilian Conference on Tribology TriboBr, Rio de Janeiro, Brazil, 2010.

[7] VIÁFARA, C.C., Transição no regime de desgaste por deslizamento dos aços: Uma abordagem termodinâmica. 2010, 250p. Tese (Doutorado em engenharia mecânica). Programa de pós-graduação em engenharia mecânica, Escola Politécnica da USP, São Paulo. 


\section{Capítulo 14}

Estudo da obtenção de M02C por reação gás-sólido em reator de leito fixo e rotativo

\section{Camila Pacelly Brandão de Araújo}

Carlson Pereira de Souza

Maria Veronilda Macedo Souto

Cleonilson Mafra Barbosa

Antonia Vanessa Vasconcelos Martins Frota

Resumo: A obtenção de carbetos via reação gás-sólido permite superar muitas das dificuldades de outros processos. Na reação de síntese de carbetos em reatores de leito fixo (LF) o sólido precursor é permeado pela corrente gasosa formando um leito empacotado sem mobilidade. 0 uso de um reator cilindro rotativo (CR) permitiria acrescentar um caráter de mistura a esse processo. Neste trabalho HMA (heptamolibdato de amônio) foi submetido à reação de carbo-redução $(\mathrm{CH} 4 / \mathrm{H} 2)$ em ambos os reatores sob mesma vazão $(15 \mathrm{~L} / \mathrm{h})$ e temperatura $\left(660^{\circ} \mathrm{C}\right)$ por 180 minutos. Foi observada completa conversão a Mo2C ( $\mathrm{dp}=18.9 \mathrm{~nm}$ modal) no reator de leito fixo, apesar de no CR essa conversão ter sido parcial ( $\sim 80 \%)$ sendo identificadas por DRX as fases Mo2C e MoO3 ( $\mathrm{dp}=34 \mathrm{~nm}$ bimodal). A conversão parcial foi atribuída à necessidade de uso de maior carga de sólidos no reator CR (50\% superior) para evitar centrifugação.

Palavras-chave: carbeto de molibdênio, reator de leito fixo, reator rotativo, reação gássólido. 


\section{INTRODUÇÃO}

Materiais do tipo carbetos apresentam grande versatilidade. Seu uso fundamental se dá na produção de aços especiais, onde atua conferindo propriedades diferenciadas, como maiores resistências à temperatura e à abrasão, dureza, etc. $(1,2)$. Um segundo uso, mais recente e igualmente promissor, é em catálise heterogênea atuando em reações da indústria do refino de petróleo como hidrogenação, hidrodessulfurização (HDS) e hidrodesaromatização (HDA) de compostos leves e pesados (3-5).

As propriedades obtidas são, em grande extensão, decorrentes do processamento empregado: moagem de alta energia, plasma, deposição de vapor, etc. $(1,6,7)$. A síntese de carbetos via gás-sólido permite superar muitas das dificuldades dos outros processos, sendo capaz de produzir pós com bom controle de tamanho das partículas, forma e estrutura cristalina $(8,9)$ devido à interação fluido-partícula ser mais homogênea que as demais abordagens de síntese. Adicionalmente, a difusão das espécies se dá em meio gasoso, permitindo alcançar maiores velocidades de transferência de massa quando comparado com a rota metalúrgica tradicional.

Um reator de leito fixo caracteriza-se por um modo de contato no qual a fase gasosa permeia a fase sólida contida em um leito empacotado. Devido à sua simplicidade, associada a baixos custos de construção, operação e manutenção esse tipo de reator é amplamente usado na indústria química, apesar de se prestar mais adequadamente a processos em pequena escala. Para a síntese de carbetos nesse reator os sólidos são alimentados em barquetes ou cadinhos refratários, os quais são inseridos em um compartimento de forno (resistivo ou à queima de combustíveis) onde o fluxo de gases se dá. Nessas condições, as partículas de pó estão em um leito fixo, no sentido em que se encontram imobilizadas sobre o cadinho, porém não existe um empacotamento de leito em todo o volume do reator. As dificuldades usualmente relacionadas com o emprego de reatores de leito fixo em termos técnicos de processamento referem-se principalmente à transferência de calor. Isto se deve ao fato de que a taxa de liberação ou consumo de energia ao longo do comprimento do reator não ser uniforme.

Alternativamente, em reações gás-sólido em reator cilindro rotativo é permitido a mistura do material devido a rotação do leito, o qual é exposto ao calor da superfície interna do reator e ao fluxo de gases reagentes. Assim, a rotação permite a maior interação entre as fases gasosa e sólida, adicionando um fator fluidodinâmico importante é aos processos de transferência de calor e massa já observados no leito fixo. A utilização de reatores desse tipo almeja o aumento de escala da síntese desses materiais.

\section{MATERIAIS E MÉTODOS}

Molibdato de amônio (PMA) [(NH4)2MoO4] (SIGMA ALDRICH, 99\%) foi manualmente cominuido em almofariz de ágata até uniformidade de coloração para produzir o material de partida para as reações gássólido. Esse material foi caracterizado por (Bruker - D8 Advance, $\mathrm{Cu}-\mathrm{K} \alpha, 40 \mathrm{kV}, 40 \mathrm{~mA}$ ), MEV (QUANTA200FEG) e TG/DTA (NETZSCH TG 209F3).

Para as reações em leito fixo aproximadamente $2 \mathrm{~g}$ desse material foi adicionado a cadinho de alumina $2 \mathrm{~g}$, a qual foi carregada no reator de leito fixo de alumina (dext $=35 \mathrm{~mm}, \mathrm{~L}=80 \mathrm{~cm}$ ) acoplado a forno resistivo (EDG Túnel FTHI-40, Brasil), conforme ilustrado na Fig. 1, onde a reação gás-sólido foi processada. 0 reator foi purgado com Argônio (Linde, Brasil, 99\%) por aproximadamente $30 \mathrm{~min}$. e em seguida, o fluxo de CH4 (5\%) e H2 (Linde, Brasil, 95\%) foi iniciado à vazão de 15 L.h-1 controlada por rotâmetros e controladores mássicos. As amostras foram submetidas a aquecimento sob taxa de $5^{\circ} \mathrm{C}$.min-1, até a temperatura de $660^{\circ} \mathrm{C}$ tendo sido mantidas nesse patamar por $180 \mathrm{~min}$, conforme metodologia estabelecida por (10). 0 sistema foi resfriado naturalmente para que as amostras pudessem ser retiradas e acondicionadas em porta-amostras plásticos fechados. Esses materiais foram caracterizados por DR-X (SHIMADZU XRD- 6000, Cu-K $\alpha$ ), MEV (SHIMADZU MEV SSX550), Granulometria a laser ((CILAS 920 Líquido, de $0.30 \mathrm{mu}-400.00 \mathrm{mu} / 30$ classes.)e TOC (SHIMADZU TOC SSM 5000A).

Para a síntese em reator de cilindro rotativo, aproximadamente $3 \mathrm{~g}$ de precursor foi carregada no compartimento rotativo. O uso dessa quantidade de material foi necessário devido ao risco de centrifugação do pó internamente ao leito, o que não favoreceria a fluidodinâmica desejada ao se modificar o reator. 0 reator ilustrado na Fig.1 (b) foi acoplado ao mesmo sistema de fluxos de gases e forno do reator de leito fixo. As mesmas condições de fluxo de mistura gasosa, temperatura de reação, taxa de aquecimento e tempo de patamar foram utilizadas. Os produtos da reação foram caracterizador por DR-X, MEV, Granulometria a laser e TOC. 
Figura 1: Sistema utilizado para reações de carboredução. Em (a) sistema de leito fixo, indicando os equipamentos de controle de fluxo. Em (b) reator cilindro rotativo.

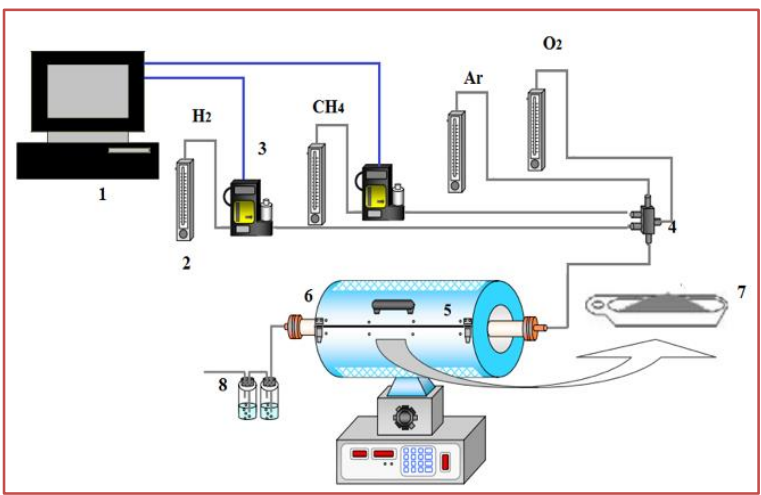

(a)

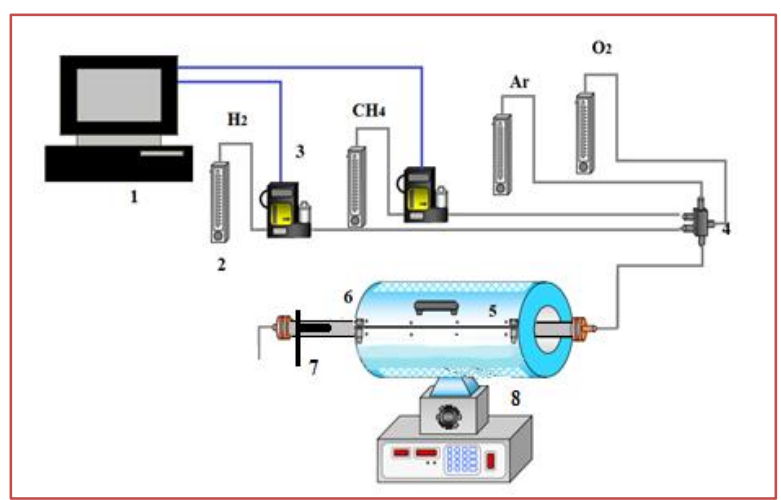

(b)

\section{RESULTADOS E DISCUSSÃo}

\subsection{AVALIAÇÃO DOS PRECURSORES:}

Avaliação de fases por DR-X: Para o precursor das reações de carbonetação foram observadas as seguintes fases cristalinas: (NH4)2MoO4 de estrutura monoclínica (ICSD - 408750) e (NH4)2Mo2O7 de estrutura triclínica (ICSD - 4152). A Figura 2 apresenta o padrão de difração.

Figura 2: DRX do molibdato do amônio. Picos indicados • por referem-se à fase (NH4)2Mo207, picos indicados por $\mathbf{\Delta}$ referem-se à fase (NH4)2MoO4. Picos indicados por $\square$ apresentam contribuição mista de ambas as fases. Principais planos cristalográficos destacados.

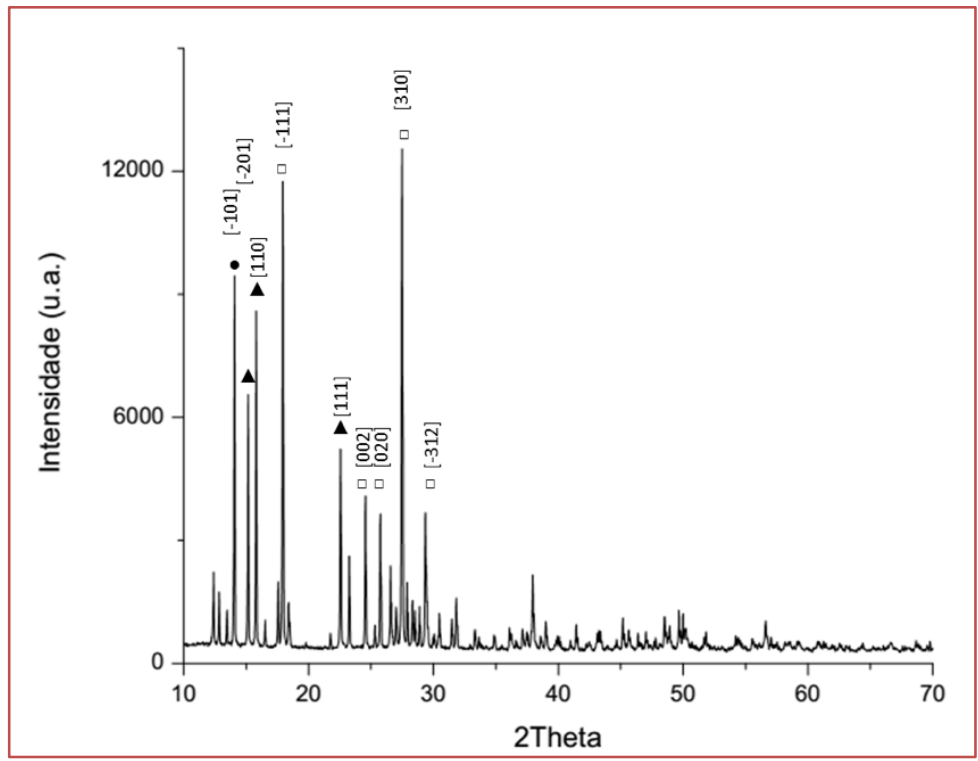

Avaliação morfológica por MEV: A Figura 3 apresenta imagens de MEV para o material de partida (PMA). Nota-se a grande variação de tamanhos de aglomerados (a) e ausência de porosidade aparente e a forma de plaquetas com contornos arredondados (b). Esse material teve seu tamanho médio de partícula estimado em $12.06 \mu \mathrm{m}$. 
Figura 3: Microscopia eletrônica para o PMA com aumentos de 150x (a) e 2000x (b).

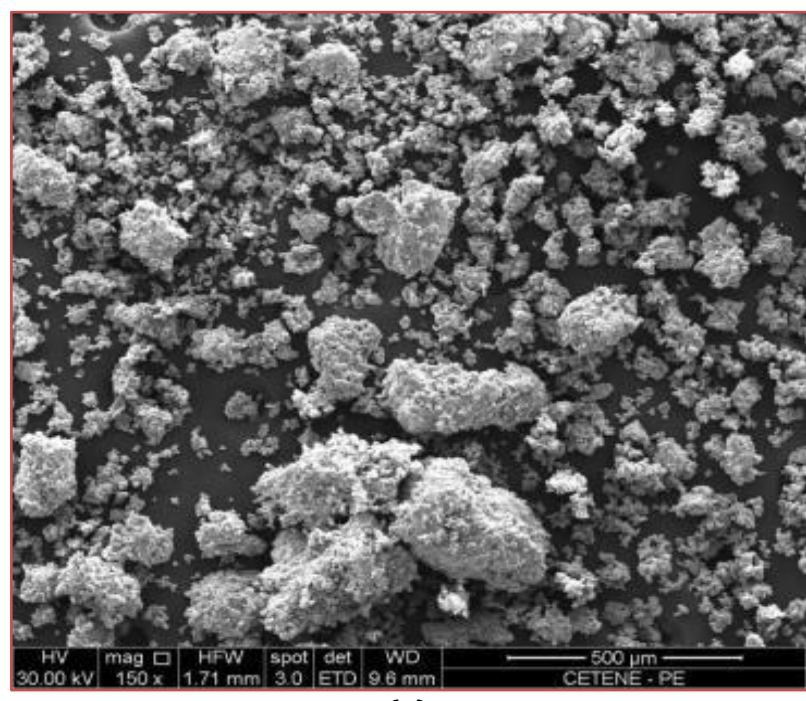

(a)

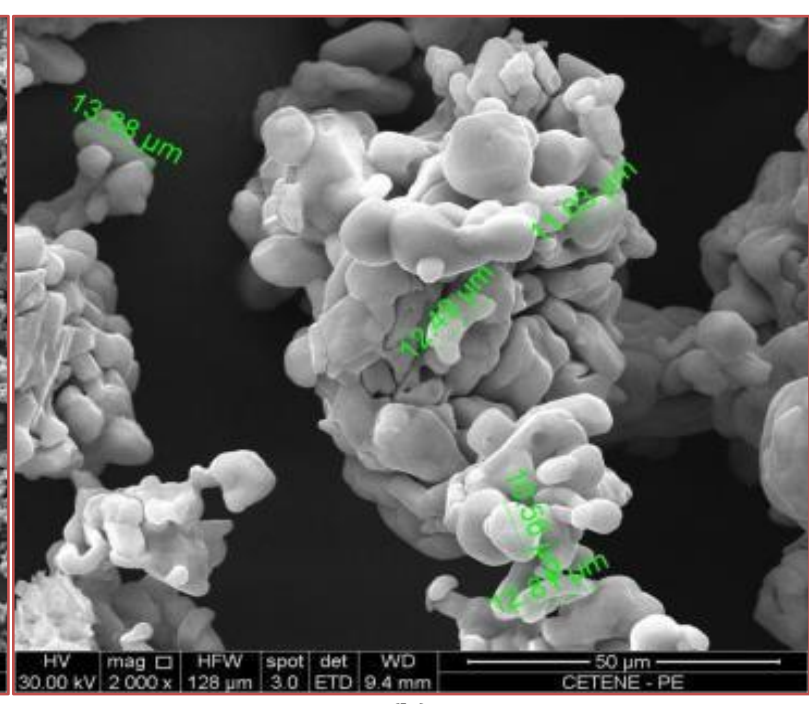

(b)

Avaliação de estabilidade térmica (TG/DTA): A Figura 4 apresenta o perfil de decomposição térmica para o precursor utilizado nesse estudo. A Tabela 1 indica os eventos de perda de massa e lhes quantifica. Cinco eventos de perda de massa foram observados, todos endotérmicos nos intervalos de temperatura de 90 a $160^{\circ} \mathrm{C}, 180$ a $210^{\circ} \mathrm{C}, 210$ a $245{ }^{\circ} \mathrm{C}, 250$ a $310{ }^{\circ} \mathrm{C}$ e 310 a $405{ }^{\circ} \mathrm{C}$, totalizando aproximadamente $24 \%$ de perda de massa. Esses eventos são relativos à volatilização da amônia e perda de água livre ao longo do intervalo de temperatura. Desse modo, o resultado está de acordo com a literatura se a obtenção de MoO3 é observada após a calcinação $(11,12)$, como foi o caso..

Figura 4: Perfil termogravimétrico para o PMA.

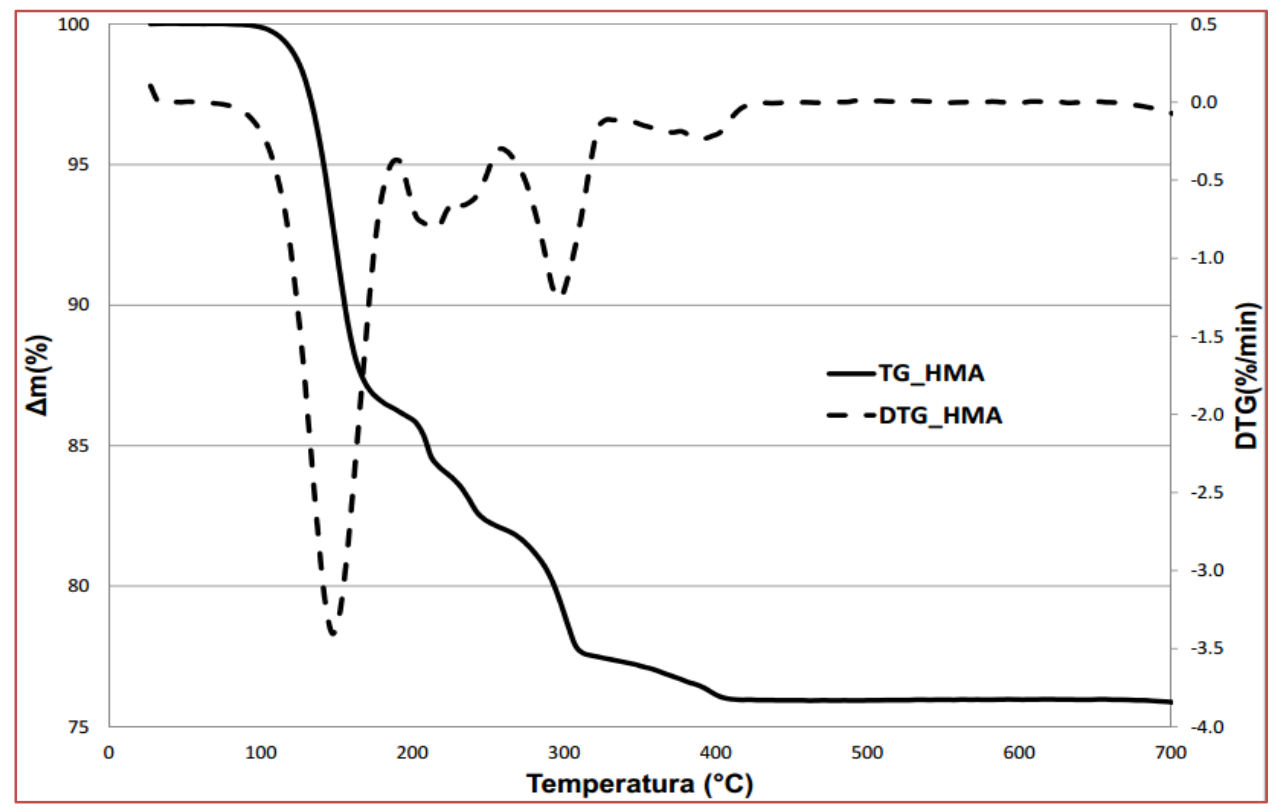


Tabela 1: Perfil de decomposição térmica do molibdato de amônio.

\begin{tabular}{|c|c|c|c|}
\hline Eventos & $\Delta \mathrm{m}$ & Tinício $\left({ }^{\circ} \mathrm{C}\right)$ & Tfinal $\left({ }^{\circ} \mathrm{C}\right)$ \\
\hline 1 & 11.9 & 90 & 160 \\
\hline 2 & 3.5 & 180 & 210 \\
\hline 3 & 2.4 & 210 & 245 \\
\hline 4 & 4.3 & 250 & 310 \\
\hline 5 & 1.9 & 310 & 405 \\
\hline Total & 24.0 & & \\
\hline
\end{tabular}

\subsection{AVALIAÇÃO DOS PRODUTOS DA REAÇÃO DE CARBOREDUÇÃO:}

Avaliação por DR-X: Os carbetos oriundos da reação de carbonetação foram analisados por difração de raios-X. 0 padrão obtido encontra-se na Figura 5. Os picos que não são referentes à fase Mo2C (ICSD: 001326 - Ortorrômbica) encontram-se destacados. Nota-se que esses picos são de baixa intensidade e se referem à fase MoO3(ICSD: 030258 - Ortorrômbica), intermediária na obtenção de carbetos por essa metodologia.

Figura 5: Padrão de difração para os produtos da reação de carbonetação.
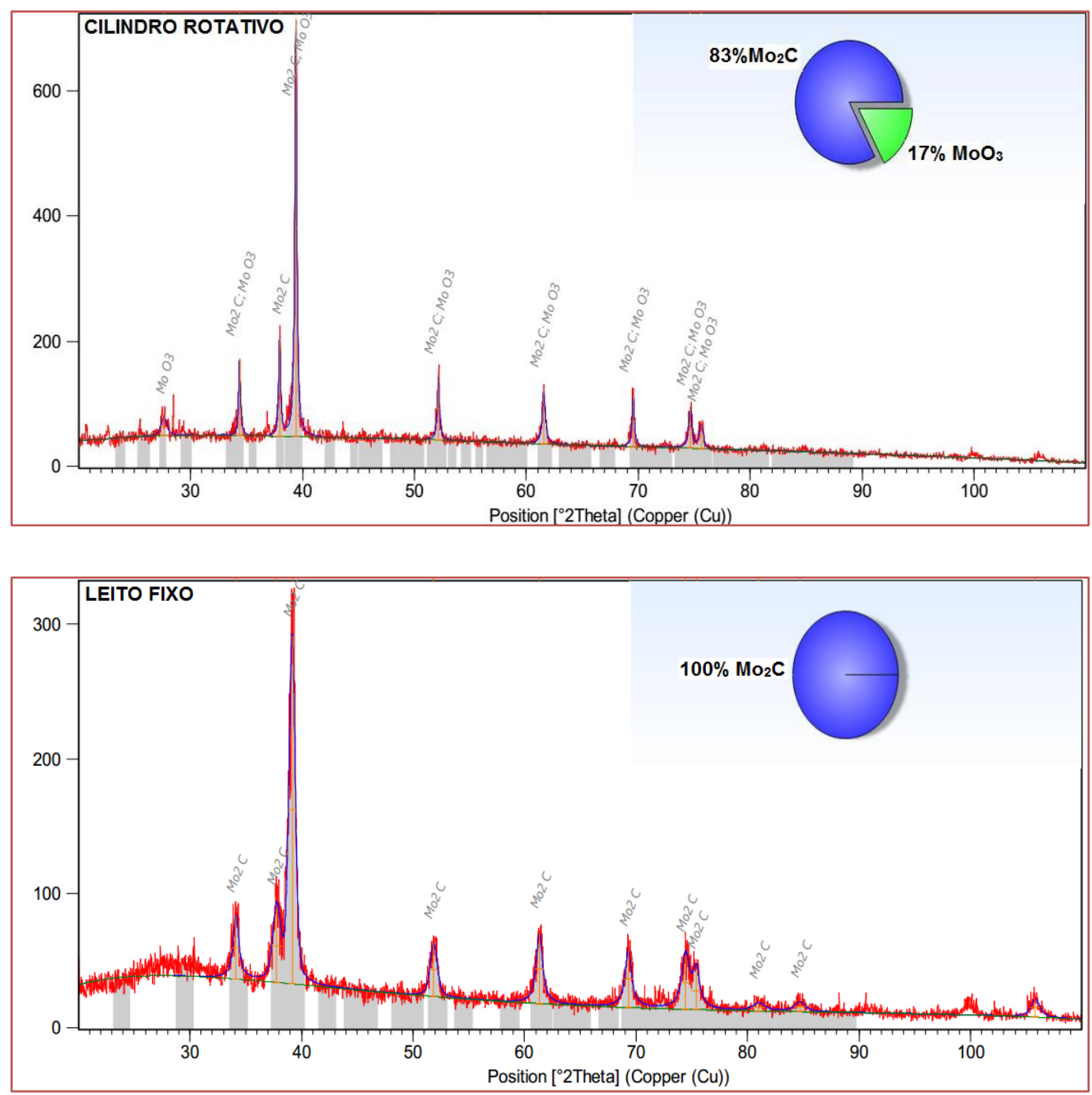
Estimativa do tamanho de cristalito: A estimativa do tamanho de cristalito para os produtos da reação de carbo-redução foi realizada com base no perfil de difração de raios-X obtido através da metodologia de Scherrer. Para os produtos oriundos da reação em leito fixo o diâmetro médio de partícula foi estimado em $11.8 \mathrm{~nm}$ e para os produtos oriundos do reator rotativo o diâmetro médio foi de $32.3 \mathrm{~nm}$. Es

se resultado é condizente com o observado na análise de DRX, a qual indica a presença de óxido no material do cilindro rotativo, uma vez que o mecanismo de produção de carbetos passa pela quebra das partículas de óxidos intermediários produzindo material de tamanho final menor(13).

Avaliação por TOC: Análises de teor de carbono foram realizadas em ambos os produtos da reação de carbonetação. Para o material produzido em leito fixo o teor de carbono foi próximo aos teóricos 5,88\% atingindo um valor de 5,67\% correspondendo a uma conversão de 96,4\%. Esse resultado está dentro da margem de erro experimental das metodologias de análise. Já no reator cilindro rotativo o percentual de carbono alcançado foi de 3,45\%. Esse teor corresponde a uma conversão de 41,32\% do material. Esse valor difere do calculado pelo padrão de difração desse material. Essa diferença pode ser devida ao fato de a última metodologia se aplicar a picos que estão simultaneamente presentes em ambas as fases, tornando a estimativa a partir do padrão de difração menos adequada à estimativa da conversão da reação.

Análise por Granulometria a laser: A amostra do produto da reação em reator de leito fixo apresentou diâmetro de aglomerados de 15, 29 m com uma distribuição bimodal. Por sua vez, a amostra do produto da reação em reator cilindro-rotativo, apresentou tamanho médio de aglomerados de 36,28 $\mu$ m e distribuição modal. Esses resultados são concordantes com as observações de microscopia e de difração de raios-X onde se observa aglomerados maiores para o produto do reator rotativo. Além disso, indica que a rotação utilizada pode ter sido superior à adequada para a fluidização do leito conforme movimento em cascata, tendo ocorrido centrifugação do material nas paredes do reator. 0 que levaria a um mecanismo homogêneo de reação.

Figura 7: Distribuição granulométrica para os produtos da reação de carbo-redução. Em (a) produto do leito fixo e em (b) do cilindro rotativo.

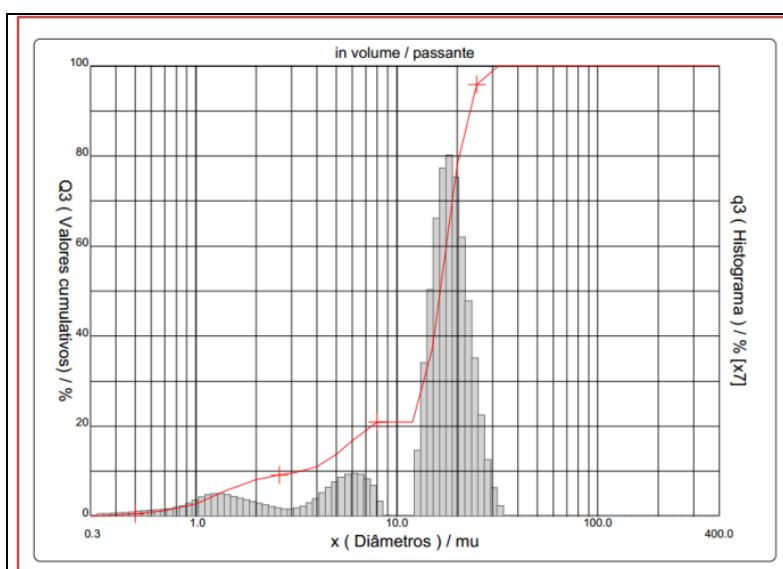

(a)

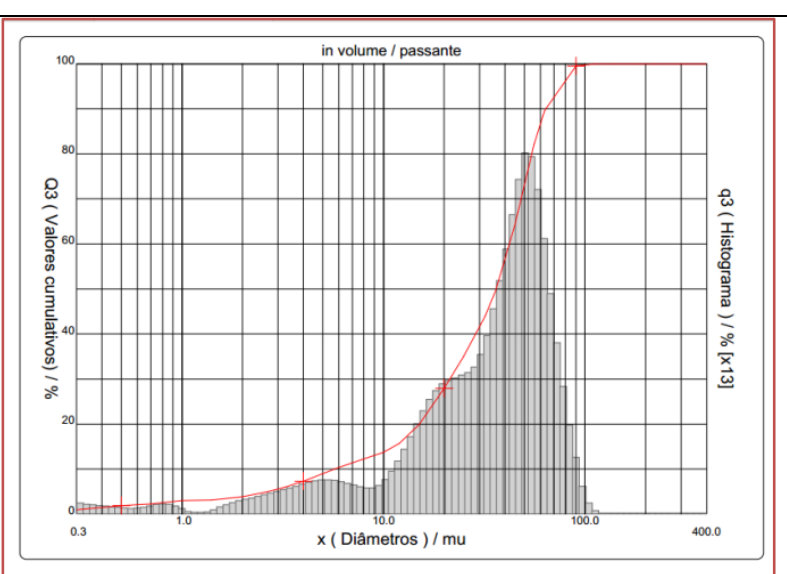

(b)

Análise por Microscopia Eletrônica de varredura (MEV): A análise morfológica para os produtos da reação de carbonetação é apresentada na Figura 6. A amostra do produto produzido em reator de leito fixo (a e c) apresentou particulado fino, de forma indefinida e aglomeradas cujo tamanho médio foi estimado em $73,15 \mu \mathrm{m}$. A formação de partículas de formato indefinido é característica da obtenção de carbeto de molibdênio $(10,14)$. Por sua vez, a amostra do produto da reação no cilindro rotativo (b), apresentou-se com forte aglomeração de partículas com tamanho médio de aglomerados estimado em 186,6 $\mu \mathrm{m}$ e características mistas entre carbetos (de formato indefinido) e óxido (com semelhança a plaquetas). A presença de partículas de maior tamanho nos produtos da carbo-redução em reator cilindro rotativo, confirma o resultado obtido por difração de raios-X e a estimativa de tamanho de cristalito realizada. Após a carburização, a morfologia do carbeto se apresenta como uma aglomeração de partículas isotrópicas a partir da quebra das plaquetas de óxido de molibdênio, o que indica um processo não-topotático devido à fonte de carbono utilizada(15). 
Figura 6: Imagens de microscopia para os produtos da reação de carbo-redução em reator de leito fixo (a) com aumento de 100x e (c) com aumento de 400x, e em reator cilindro rotativo (b) com aumento de 100x e (d) com aumento de 400x.

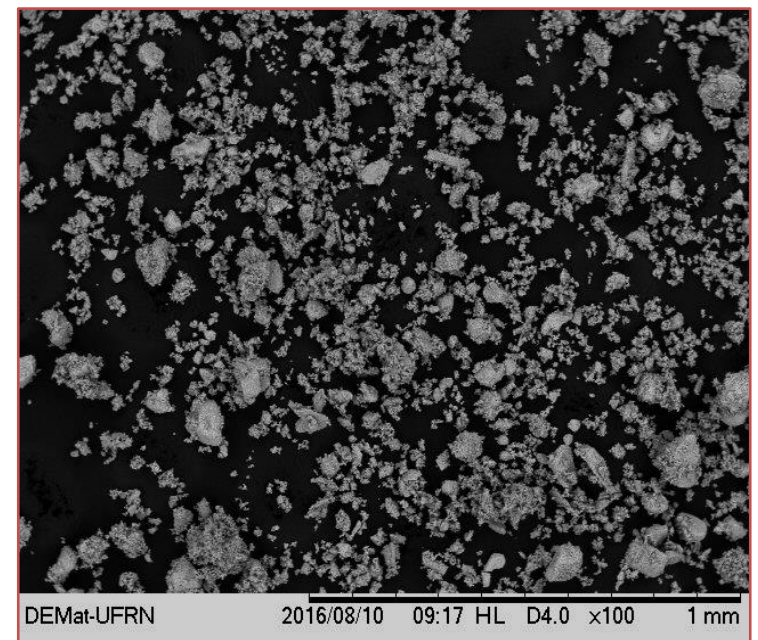

(a)

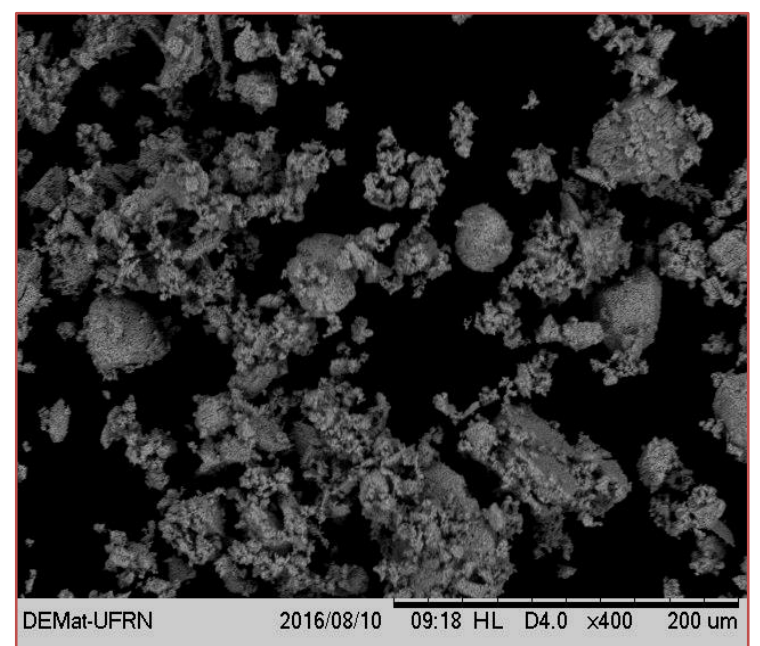

(c)

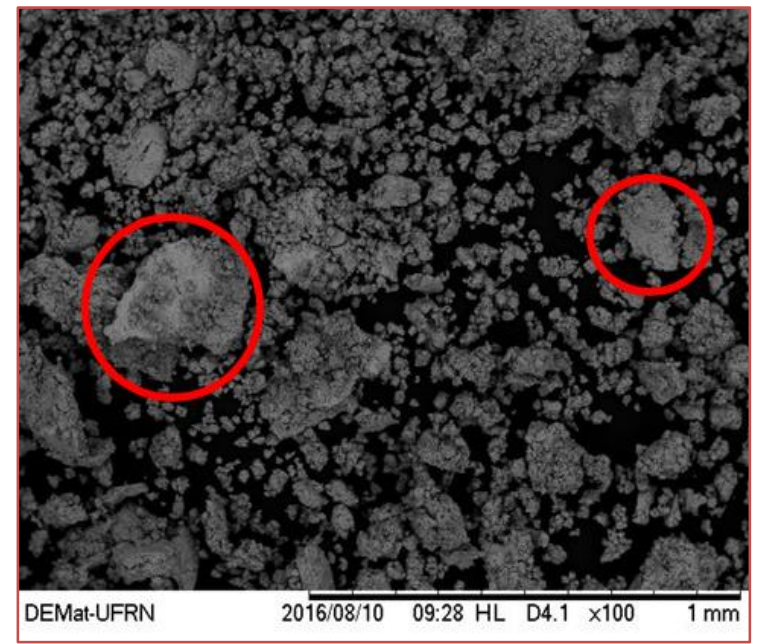

(b)

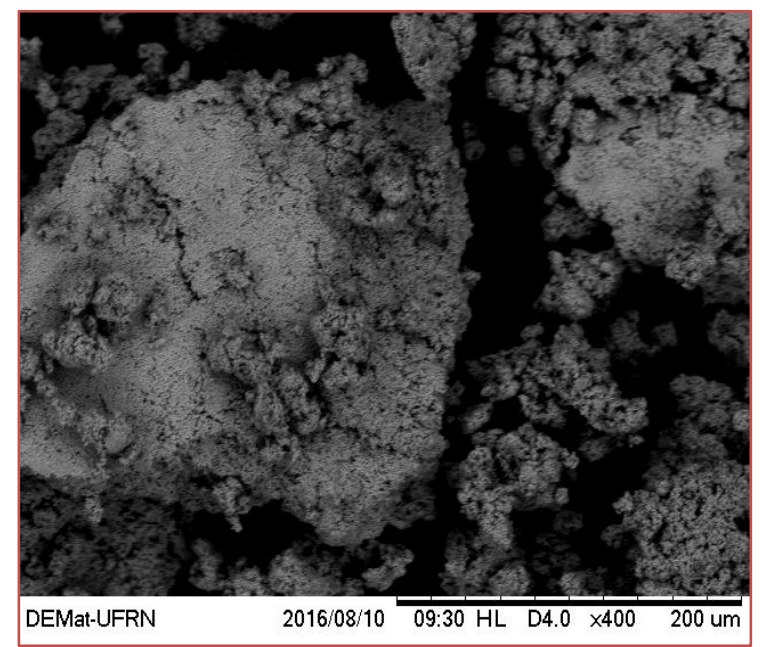

(d)

\section{CONCLUSÕES}

Com base no exposto, pode-se concluir que a obtenção de carbeto de molibdênio puro por meio de reação gás-sólido em atmosfera de $\mathrm{CH} 4$ e $\mathrm{H} 2$ com vazão de 15L/h é possível em reator de leito fixo à temperatura de $660^{\circ} \mathrm{C}$, com tempo de patamar de $180 \mathrm{~min}$. Em reator rotativo, porém, não foi possível alcançar a completa conversão nessas condições.

As análises de DRX dos produtos da reação de carbonetação indicaram para os materiais oriundos do reator de leito fixo a obtenção de Mo2C, para os do reator rotativo um material de composição mista de Mo2C e Mo03 foi obtido. A estimativa pelo software XPert Highscore indicou, a partir do padrão de difração $17 \%$ da fase óxido, e $83 \%$ de carbeto para o material produzido em reator rotativo. A avaliação, porém por teor de carbono, indicou uma conversão bastante inferior, próxima aos 50\%.

As avaliações morfológicas dos produtos da reação foram concordantes com as observações de difração de raios-X. Foi possível observar a formação de produto aglomerado isotrópico de finas partículas para o material oriundo de reator de leito fixo, e de um material com particulado maior para os produtos de reator rotativo. As características apresentadas pelo material produzido em leito fixo são condizentes com o observado na literatura para o carbeto de molibdênio. Já o material produzido em reator rotativo apresentou-se com aglomerados de plaquetas, indicativo da fase óxido, com carbeto de molibdênio de pequeno tamanho de partícula ao redor. 


\section{REFERÊNCIAS}

[1] Pierson HO. Handbook of refradory carbides and nitrides :properties, characteristics, processing and applications. Bunshah, Rointan F.; McGuire, G. E.; Rossnagel SM, editor. Westwood, New Jersey: Noyes Publications; 1996. $360 \mathrm{p}$.

[2] Buchel, K. H.; Moretto, H. H.; Woditsch P. Industrial Inorganic Chemistry. 2nd ed. Wiley-VCH; 2000.

[3] Grange P, Vanhaeren X. Hydrotreating catalysts, an old story with new challenges. Catal Today. 1997;36(4):375-91.

[4] Furimsky E. Metal carbides and nitrides as potential catalysts for hydroprocessing. Appl Catal A Gen. 2003;240(1-2):1-28.

[5] Furimsky E. Properties of catalysts for hydroprocessing of heavy feeds. In: Catalysts for Upgrading Heavy Petroleum Feeds. p. 23-41.

[6] L. E. Toth. Transition Metal Carbides and Nitrides. Acad Press [Internet]. 197AD;1(13):279. Available from: http://doi.wiley.com/10.1002/ange.19720841920

[7] Sarin VK. Comprehensive Hard Materials. Mari, Daniele; LLanes, Luis; Nebel CE, editor. Elsevier; 2014. 1774 p.

[8] Liu K. Tungsten Carbide - Processing and applications. . Borovinskaya, T. Ignatieva, V. Vershinnikov, A.K. Nanda Kumar, Kazuya Kurokawa, Marcin Madej, Zbigniew Pędzich, Paweł Twardowski, Szymon Wojciechowski YF, editor. Intechopen.com; 2012.146 p.

[9] Fang ZZ, Wang X, Ryu T, Hwang KS, Sohn HY. Synthesis, sintering, and mechanical properties of nanocrystalline cemented tungsten carbide - A review. Int J Refract Met Hard Mater [Internet]. Elsevier Ltd; 2009;27(2):288-99. Available from: http://dx.doi.org/10.1016/j.ijrmhm.2008.07.011

[10] Gomes KKP. Síntese e caracterização co carbeto de molibdênio nanoestruturado para fins catalíticos na reação de oxidação parcial do metano. Universidade Federal do Rio Grande do Norte; 2006.

[11] Wienold J, Jentoft RE, Ressler T. Structural Investigation of the thermal decomposition pof ammonium heptamolybdate by in-situ XAFS and XRD. 2002;

[12] Wienold J, Jentoft RE, Timpe 0, Ressler T. Insight in the thermal decomposition of Ammonium Heptamolybdate. 2001;4-5.

[13] Ma Y, Guan G, Shi C, Zhu A, Hao X, Wang Z, et al. Low-temperature steam reforming of methanol to produce hydrogen over various metal-doped molybdenum carbide catalysts. Int J Hydrogen Energy [Internet]. Elsevier Ltd; 2014;39(1):258-66. Available from: http://dx.doi.org/10.1016/j.ijhydene.2013.09.150

[14] Mo T, Xu J, Yang Y, Li Y. Effect of carburization protocols on molybdenum carbide synthesis and study on its performance in CO hydrogenation. Catal Today [Internet]. Elsevier B.V.; 2016;261:101-15. Available from: http://dx.doi.org/10.1016/j.cattod.2015.07.014

[15] Löfberg A, Frennet A, Leclercq G, Leclercq L, Giraudon JM. Mechanism of W03 Reduction and Carburization in $\mathrm{CH} 4 / \mathrm{H} 2$ Mixtures Leading to Bulk Tungsten Carbide Powder Catalysts. J Catal [Internet]. 2000;189(1):170-83. Available from: http://www.sciencedirect.com/science/article/pii/S0021951799926921\nhttp://linkinghub.elsevier.com/retrieve/ pii/S0021951799926921 


\section{Capítulo 15}

Effect of nitrogen treatment on $\mathrm{Nd}-\mathrm{Fe}$-B based powder

\section{Marcelo Demétrio Magalhães \\ Juliano Assis Baron Engerroff \\ Paulo Antônio Pereira Wendhausen}

Abstract: For high performance applications, one type of magnets used are Nd-Fe-B based magnets. In this context, to implement those components key properties must be enhanced, such as the intrinsic coercivity and remanence. To achieve this, it was proposed to explore the nitrogenation of $\mathrm{Nd} 2 \mathrm{Fe} 14 \mathrm{~B}$ powders, using as motivation its effect on R2Fe17 and RFe11Ti intermetallic compounds (R=Rare Earth Elements), improving its magnetic properties. From the results obtained of the processing routes under $\mathrm{N} 2$ atmosphere, main phase (Nd2Fe14B) decomposes at higher temperatures of processing, affecting magnetic properties. For longer times of exposition under N2 atmosphere and $673 \mathrm{~K}$, coercivity decreased.

Key Words: Permanent magnets; NdFeB; nitrogenation 


\section{INTRODUCTION}

Permanent magnets are critical components for electric motors and powers generators, therefore, for high performance applications their demand has been increasing. In order to adequate magnets for applications such as green energy generation, electronic devices and wind turbines, magnetic properties need to be enhanced. To this purpose, different methods have been studied, for example, the addition of substitutional elements such as Dy and Co to these alloys (1). Although this approach is effective to improve magnet properties, those elements are not cost effective, and due to the high supply risk of Rare Earth Elements such as Dy, these elements are listed as critical materials by the U.S. Department of Energy (2). In that case, other alternatives need to be explored.

A method that was already studied is the nitrogenation of intermetallic compounds R2Fe17 and RFe11Ti $(3,4)$. Through the insertion of interstitial nitrogen, magnetization and anisotropy field are increased, consequently improving remanence $(\mathrm{Br})$ and intrinsic coercivity (Hcj). Meanwhile, on R2Fe14B compounds the actual effect of this treatment vary, accordingly to results obtained by other authors. It was reported by Kou et al and Tsujikawa et al $(5,6)$ that the values decreased, opposite to Constantinescu et al and Liu et al $(7,8)$, that used materials obtained by thin films growth and mechanical alloying respectively.

On this context, it is aimed to investigate the effect of the nitrogen treatment on Nd2Fe14B powder and probable development of $\mathrm{Nd} 2 \mathrm{Fe} 14 \mathrm{BNx}$ phase, verifying its magnetic properties and microstructural characteristics.

\section{EXPERIMENTAL}

The starting material used for the process was Nd2Fe14B nanocrystalline powder obtained by atomization process, known as MQP-S-9-8, with a median particle size of 35 55 $\mu \mathrm{m}$.

Nitrogenation was performed heating the raw material (R.M) using two different routes: On route 1, temperature of processing for each sample was varied between $673 \mathrm{~K}$ and $1173 \mathrm{~K}$, with $100 \mathrm{~K}$ steps, for a total time of 10 hours under nitrogen atmosphere. On route 2, time exposition of the powder under N2 atmosphere was varied and processing temperature was $673 \mathrm{~K}$. Periods of processing used were 10, 30, 50,70 and 100 hours. The heating for both routes was carried out under vacuum, with a rate of $10 \mathrm{~K} / \mathrm{min}$. After reaching the desired temperature, a pressure of $100 \mathrm{kPa}$ of $\mathrm{N} 2$ gas was stablished.

Succeeding the nitrogenation, each sample undergone magnetic characterization using a hysteresigraph Brockhaus Messtechnik EM180. Values of intrinsic coercivity and remanence obtained were compared with the values of the raw material, not exposed to the heat treatment cycles. For microstructural evaluation and thermic behavior before and after processing, X-ray diffraction (XRD) and differential scanning calorimetry (DSC) with a nitrogen flux of $100 \mathrm{ml} / \mathrm{min}$ were conducted respectively.

\section{RESULTS AND DISCUSSION}

Demagnetization curves for samples processed on different temperatures are shown on Fig. 1. There was no significant changes on $\mathrm{Br}$ and $\mathrm{Hcj}$ for 673, 773 and $873 \mathrm{~K}$ curves. However, for temperatures of $973 \mathrm{~K}$ and higher, a reduction of those properties was noted and is discussed below. Values for each curve are observed on Table 1.

During nitrogenation of Sm2Fe17 phase, the main phase after processing, Sm2Fe17N3, decomposes into $\mathrm{SmN}$ and $\alpha-\mathrm{Fe}$ on temperatures close to $873 \mathrm{~K}$. Therefore, the same way as $\mathrm{Sm}-\mathrm{Fe}-\mathrm{N}$ based alloys, Nd2Fe14B phase could decompose on higher temperatures into neodymium nitrides, $\alpha$-iron and borides. Moreover, for higher temperatures, diffusion process is increased, possibly affecting magnetic properties because of microstructural changes. 
Figure 1 - Demagnetization curves for samples processed on different temperatures for an exposition time of $10 \mathrm{~h}$ under $\mathrm{N} 2$ atmosphere.

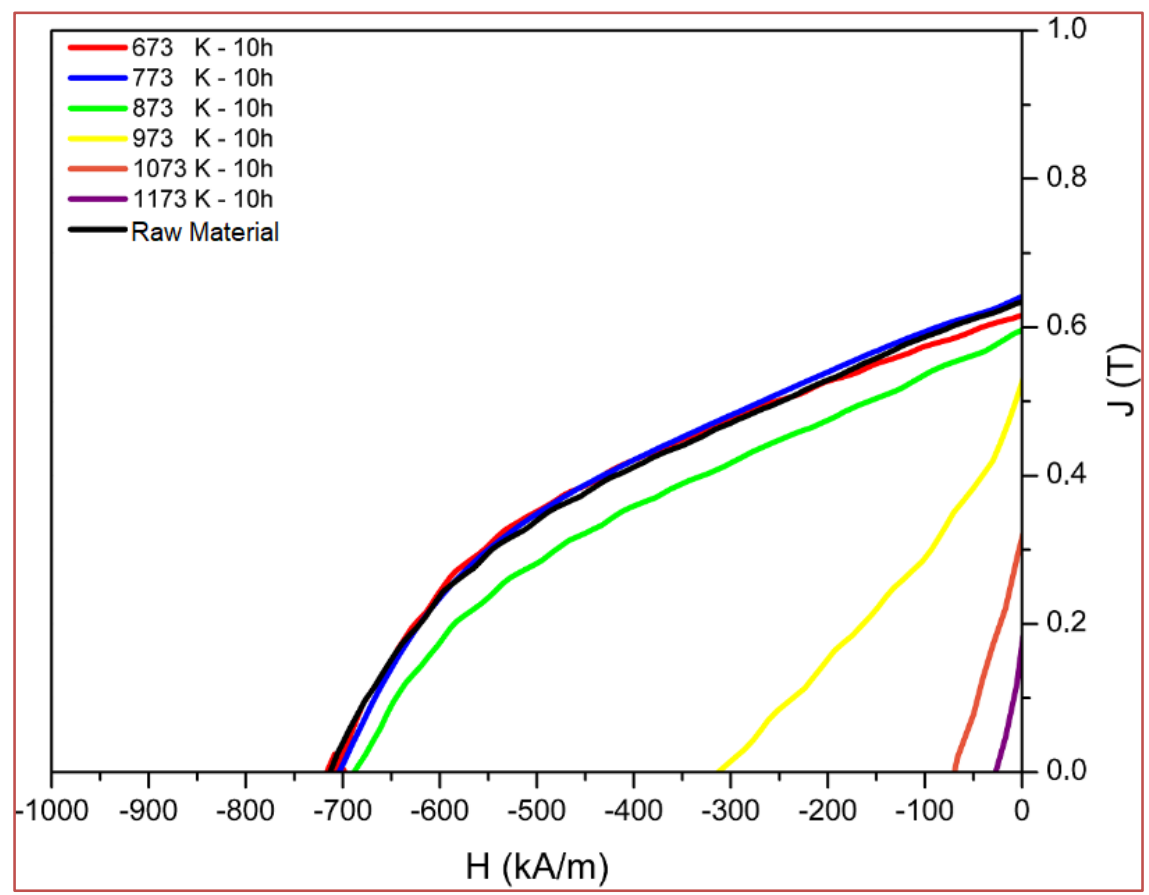

Table 1 - Br and Hcj values for samples undergone route 1.

\begin{tabular}{|c|c|c|}
\hline Temperature (K) & $\begin{array}{c}\mathrm{Br} \\
(\mathrm{T})\end{array}$ & $\begin{array}{c}\mathrm{Hcj} \\
(\mathrm{kA} / \mathrm{m})\end{array}$ \\
\hline Raw Material & 0.65 & 710.37 \\
\hline 673 & 0.62 & 707.96 \\
\hline 773 & 0.64 & 703.79 \\
\hline 873 & 0.60 & 688.25 \\
\hline 973 & 0.53 & 313.80 \\
\hline 1073 & 0.32 & 66.60 \\
\hline 1173 & 0.17 & 27.15 \\
\hline
\end{tabular}

Demagnetization curves for samples obtained through route 2 are displayed on Fig. 2, Table 2 exhibit its values of Br and Hcj. For lower periods of processing, samples did not present large variations on intrinsic coercivity, though for periods of 50, 70 and $100 \mathrm{~h}$, values started to decay. Lower values of Hcj when compared to the raw material may be a cause of higher nitrogen diffusion. Remanence values did not exhibit expressive changes for treatments where exposition time to N2 atmosphere varied. 
Figure 2 - Demagnetization curves for samples processed for different exposition periods under N2 and temperature of $673 \mathrm{~K}$.

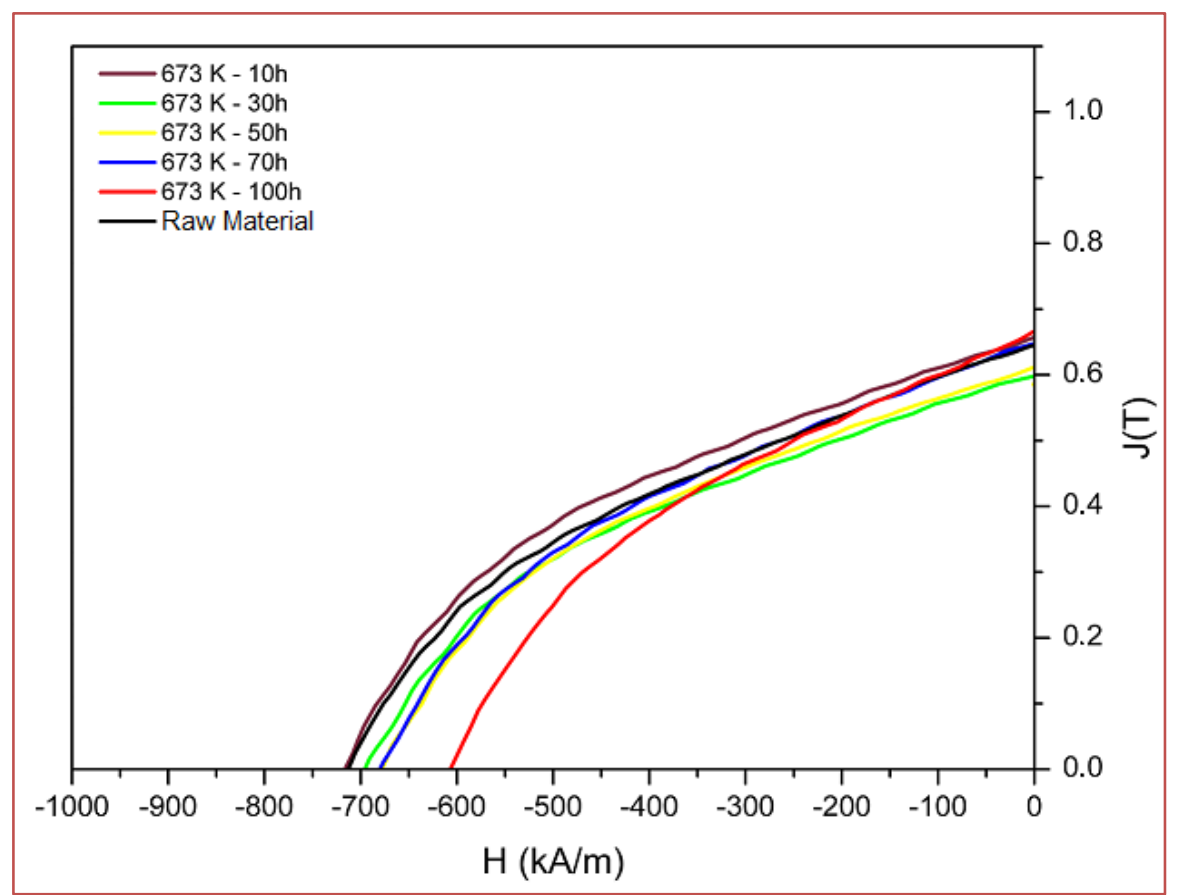

Table 2 - Br and Hcj values for samples undergone route 2.

\begin{tabular}{|c|c|c|}
\hline $\begin{array}{c}\text { Exposition Time } \\
{[\mathrm{h}]}\end{array}$ & $\begin{array}{c}\mathrm{Br} \\
{[\mathrm{T}]}\end{array}$ & $\begin{array}{c}\mathrm{Hcj} \\
{[\mathrm{kA} / \mathrm{m}]}\end{array}$ \\
\hline Raw Material & 0.65 & 710.37 \\
\hline 10 & 0.62 & 707.96 \\
\hline 30 & 0.60 & 695.87 \\
\hline 50 & 0.61 & 677.85 \\
\hline 70 & 0.65 & 680.07 \\
\hline 100 & 0.67 & 606.87 \\
\hline
\end{tabular}

Diffractograms obtained using XRD analysis for samples that were processed at different temperatures are displayed of Fig. 3. Nd2Fe14B phase was identified for temperatures of $673 \mathrm{~K}$ and $873 \mathrm{~K}$, for higher temperatures, $\alpha-\mathrm{Fe}$ and $\mathrm{NdN}$ phases were identified, confirming the phase decomposition. Hence, it was concluded that phase decomposition starts on temperatures close to $873 \mathrm{~K}$, reducing the magnetic properties, mainly intrinsic coercivity of the samples. It was not possible to identify the presence of phases containing Boron (B), probably due to the low fraction of those phases when compared to the others. Since the nitrogenation of the phase Nd2Fe14B dislocate its peaks, Nd2Fe14BNx could not be assured from the peaks positions observed. 
Figure 3 - XRD analysis for samples processed at different temperatures for a total exposition time of 10 hours.

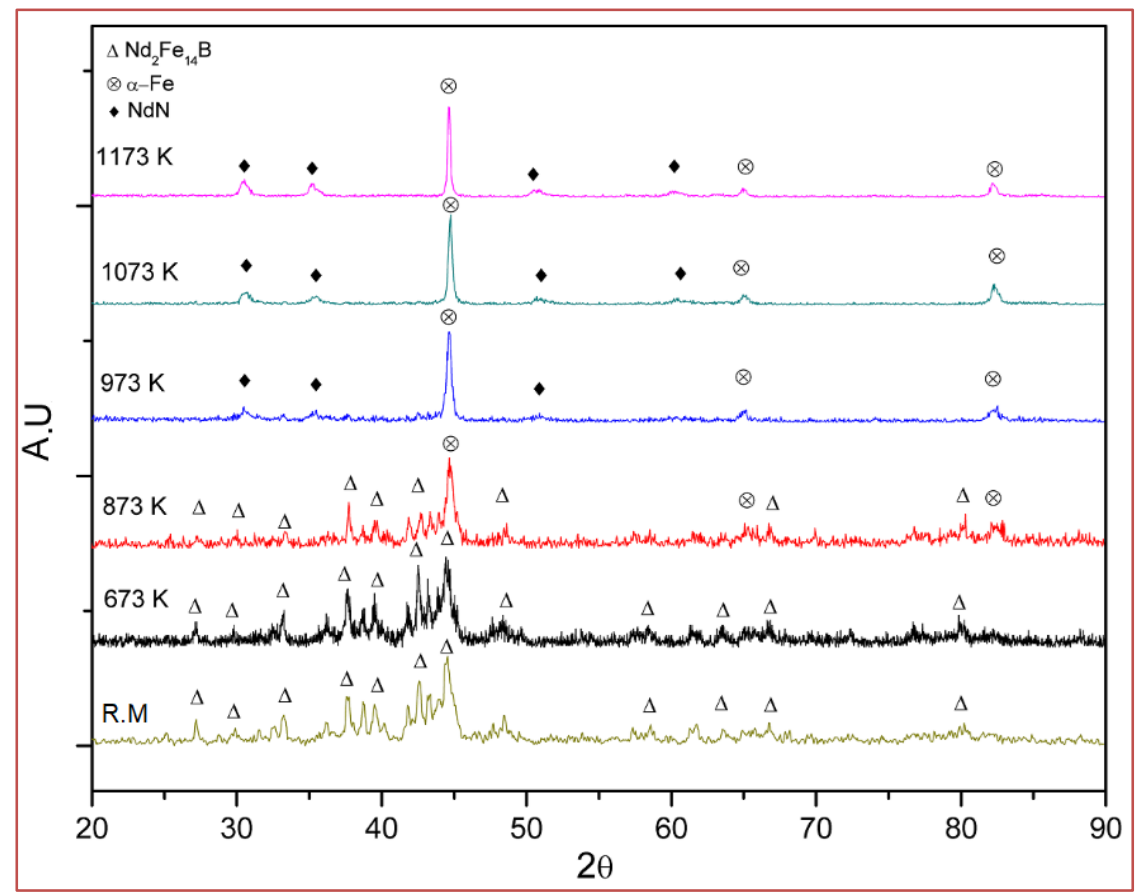

Curves obtained through DSC show an exothermic reaction between 660 and $780 \mathrm{~K}$ (Fig. 4). This reaction is likely to be a result of phase decomposition, supporting results obtained by XRD and magnetic properties analysis, that with further heating, fraction of $\mathrm{Nd} 2 \mathrm{Fe} 14 \mathrm{~B}$ decreases due to decomposition, reducing magnetic properties values consequently.

Figure 4 - DSC curves for raw material and samples processed at $673 \mathrm{~K}$ for different times of exposition under $\mathrm{N} 2$ atmosphere.

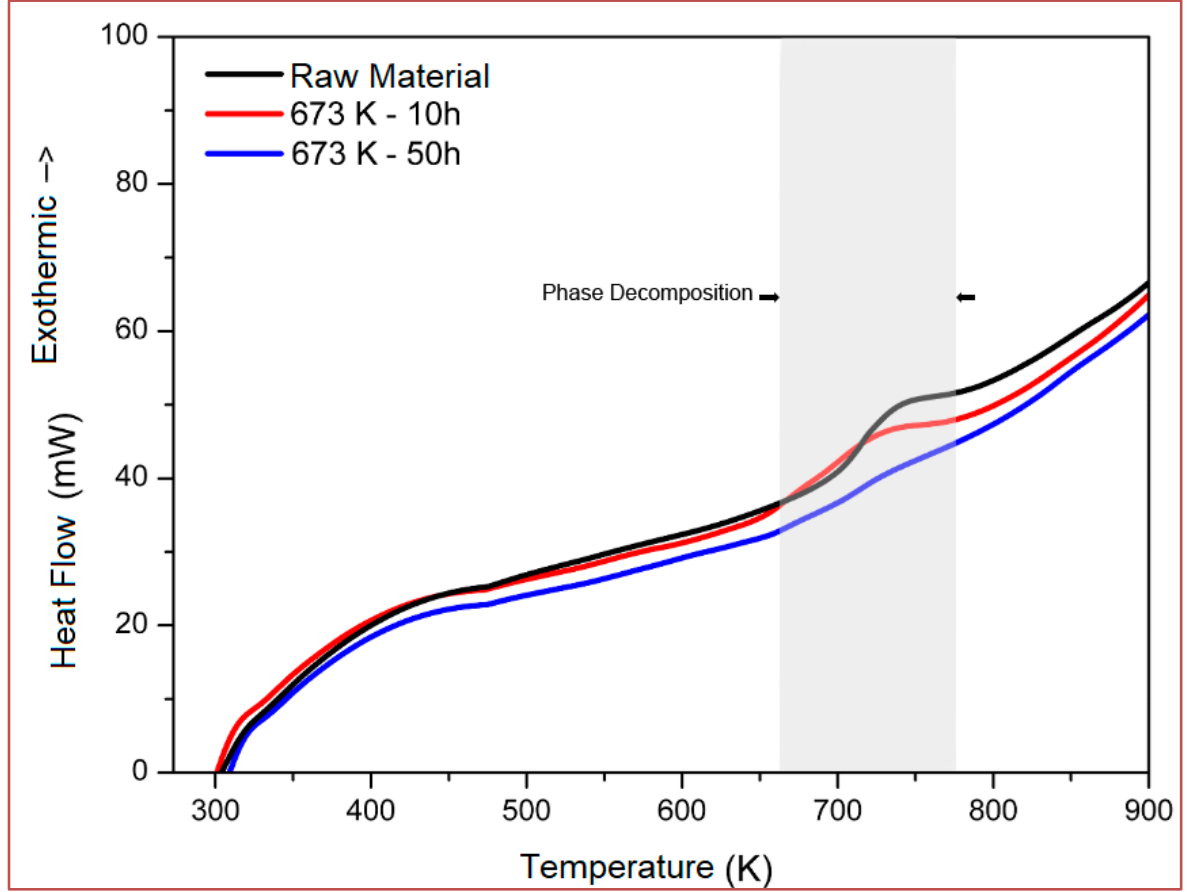




\section{CONCLUSIONS}

The heat treatment under $\mathrm{N} 2$ atmosphere applied to Nd-Fe-B based powders did not demonstrate as a viable alternative to increase magnetic properties, supporting results obtained from previous authors that rather than increasing magnetic properties, it decreases. Longer periods of processing decreased coercivity values, probably due to microstructural changes as cause of higher nitrogen diffusion. For higher temperatures, decomposition of the main phase was observed and values of $\mathrm{Br}$ and $\mathrm{Hcj}$ were lower than the raw material, due to the formation of $\mathrm{NdN}$ and $\alpha$-Fe. From the analysis conducted in this work, it was not possible to confirm interstitial nitrogen into the crystal lattice.

Although nitrogenation process did not improve magnetic properties, further analysis are under development to test other characteristics, such as corrosion resistance and thermal aging, critical properties for application of high performance magnets at higher temperatures.

\section{REFERENCES}

[1] PANDIAN, S. et al. Effect of Co, Dy and Ga on the magnetic properties and the microstructure of powder metallurgically processed Nd-Fe-B magnets. J. Alloys Compd, v. 364, p. 295-303, 2004.

[2] U.S. DEPARTMENT OF ENERGY. Critical Materials Strategy. Technical report, 2011.

[3] COEY, J. M. D.; HURLEY, D. P. F. New interstitial rare-earth iron intermetallics produced by gas phase reaction. J. Magn. Magn. Mater, v. 104-107, p. 1098-1101, 1992.

[4] YANG, Y. C. et al. Magnetic and crystallographic properties of novel Fe-rich rare-earth nitrides of the type RTiFe11N1- $\delta$ (invited). J. Appl. Phys. 70, 6001-6005 (1991).

[5] Kou, X. C., Zhao, T. S., Grossinger, R., Kirchmayr, H. R. \& Li, X. Magnetocrystalline Anisotropy of R2fe14bnx (R $=$ Pr,Nd). Phys. Rev. B. Condens. Matter, v. 46, p. 11204-11207, 1992.

[6] TSUJIKAWA, S., CHOI, P.; INO, H. Nitriding of Nd2Fe14B. Mater. Sci. Eng. A, v. 179-180, p. 408-411, 1994.

[7] CONSTANTINESCU, C. et al. Effect of nitrogen environment on NdFeB thin films grown by radio frequency plasma beam assisted pulsed laser deposition. Mater. Sci. Eng. B Solid-State Mater. Adv. Technol, v. 178, p. 267-271, 2013.

[8] LIU, W. et al. Structure and magnetic properties of $\mathrm{N}$-containing $\mathrm{Nd}-\mathrm{Fe}-\mathrm{B}$ alloys prepared by mechanical alloying. J. Appl. Phys, v. 87, p. 1-4, 2000. 


\section{Capítulo 16}

Síntese e caracterização de óxido de $\mathrm{Mn}$ nanoestruturado em camada (Ca-Ol-2) a partir de minérios da antiga mina de Serra do Navio (Amapá)

\section{Irlana Costa do Mar}

Bruno Apolo Miranda Figueira

Liliane Nogueira da Silva

José Manuel Rivas Mercury

Renata de Sousa Nascimento

Patrícia Teresa da Luz

Oscar Jesus Choque Fernandez

Resumo: Neste estudo, óxido de Mn nanoestruturado em camada, Ca-OL (octahedral layer), foi obtido a partir de minérios de Mn da Região Amazônica, os minérios de Mn de Serra do Navio (Amapá, Brasil). A rota sintética desenvolvida utilizou processos químicos de dissolução, precipitação, troca iônica e tratamento hidrotermal, respectivamente. Os resultados indicaram a presença de picos DRX na posição 12,5 e 25을 (20), confirmando a obtenção de oxido de Mn com estrutura Na-birnessita (Na-OL-1), que após troca iônica com Ca2+ se transformou em Ca-buserita (Ca-OL-2). Bandas FTIR de vibrações da ligação Mn-0 dos octaedros Mn06 foram identificadas entre 800 a 400 cm-1 e confirmam os dados obtidos por DRX. 0 comportamento termal de Ca-OL-2 obtido por TG-DTA mostrou estabilidade termal acima de $850 \stackrel{\circ}{\circ} \mathrm{C}$, demostrando dessa forma, que produtos como minérios podem ser transformados em nanolamelas de óxidos de Mn.

Palavras-chave: Amazônia, minério, síntese, óxidos de Mn, Ca-buserita. 


\section{INTRODUÇÃO}

Óxidos de Mn englobam um importante grupo de compostos inorgânicos de origem natural e sintética, que se destacam por sua diversidade estrutural, que normalmente se divide em duas principais famílias, filomanganatos e ectomanganatos. Os filomanganatos, são compostos estruturados em camada formados na natureza (minerais) a partir do compartilhamento de octaedros de $\mathrm{Mn}(3+, 4+) 06$ pelos vértices e arestas que geram estruturas em cadeias com déficit de carga que é compensado pela presença de cátions mono e divalentes, assim como moléculas de água. Dentro dessa família, pode-se destacar duas estruturas muito interessantes, sob o ponto de vista científico e tecnológico: birnessita e buserita [1-2].

Devido ao seu baixo grau de cristalinidade e presença de impurezas em amostras naturais, que dificultam a sua aplicação tecnológica, estes compostos comumente são sintetizados em laboratórios por diversos rotas sintéticas (solgel, processo oxi-redução, síntese termal e hidrotermal, dissolução e precipitação de $\mathrm{Mn}$, etc.) que em sua grande maioria utilizam reagentes comerciais como fonte de $\mathrm{Mn}$ [3-5].

0 interesse em estruturas como birnessita ou buserita, dentre outros, está na possibilidade de utilizá-las como catalisadores, adsorventes, trocadores iônicos, ou mesmo, transformá-las em outras estruturas de óxidos de manganês (túnel ou camada) ou nanotubos [6-8].

Este trabalho reporta a síntese de óxido de Mn com estrutura em camada tipo Ca-buserita obtido a partir de minérios de Mn da antiga mina de Serra de Navio (Amapá) com base nos estudos de Cornell e Giovanoli [9].

\section{MATERIAIS E MÉTODOS}

A amostra de minério (OREMN) de Mn de Serra do Navio (Amapá) foi coletado em trabalhos de campo quando a mina ainda estava em atividade, meados de 1990. Para o processo de transformação, a amostra foi tratada termalmente até formar uma única fase de óxido de Mn, que após tratamento hidrotermal com solução de $\mathrm{NaOH}$, formou um precipitado marrom (INABIR). Este produto foi secado, adicionado a uma solução de $\mathrm{CaCl} 2 * 4 \mathrm{H} 20$ por $12 \mathrm{~h}$ a $25{ }^{\circ} \mathrm{C}$ e codificado com IBUS. A caracterização dos produtos foi realizada por difração de raios X usando um difratômetro X'PERT PRO MPD, da PANalytical, com goniômetro PW3050/60 (Theta/Theta) e com tubo de raios X cerâmico de anodo de $\mathrm{Cu}(\mathrm{K} \alpha$ 1,56 ̊̊), 2200 W, $60 \mathrm{kV}$. 0 detector utilizado foi RTMS, X'Celerator. 0 espectro de infravermelho foi obtido através da mistura de 0,200 g de $\mathrm{KBr}$ e 0,0013 g de amostra pulverizada, que foi prensada a vácuo para gerar uma pastilha. Utilizou-se um espectrofotómetro FTIR Bruker Vertex 700. As curvas de TG e DTA foram obtidas num termoanalisador Stanton Redcroft de forno cilíndrico vertical. As análises foram feitas em um cadinho de platina, com aquecimento de $20^{\circ} \mathrm{C} / \mathrm{min}$, temperatura inicial e final variando de $25^{\circ} \mathrm{C}$ a $1100^{\circ} \mathrm{C}$, respectivamente.

\section{RESULTADOS E DISCUSSÕES}

A caracterização preliminar de OREMN foi realizada por difração de raios-X (DRX) e o resultado é apresentado na Fig. 1. Segundo o padrão obtido, o minério é formado principalmente por nsutita (JCPDS 014-0644), um mineral de óxido de Mn com picos a 22,7; 37,1; 42, 45; 56,2; 62, 22 e 68,77 o (20), que estão relacionados aos planos (120), (131), (300), (160), (421) e (003), respectivamente. Um pico próximo a $37,2 \stackrel{\circ}{\circ}(2 \theta)$, refere-se a presença de pirolusita (JCPDS 004-0591). 
Figura 1: Padrão de DRX de OREMN.

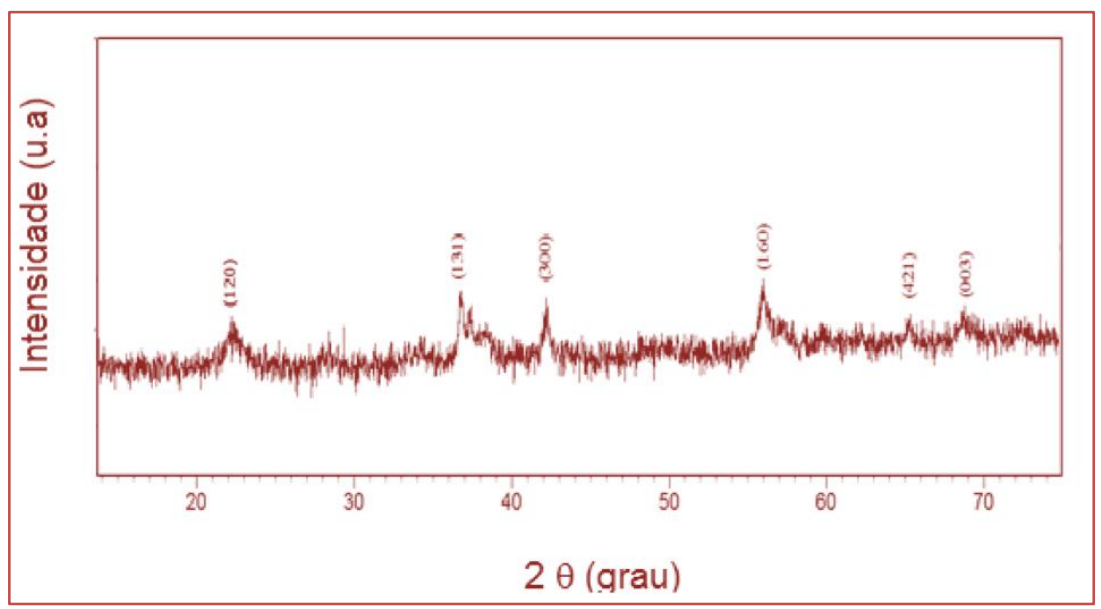

Para a amostra INABIR (Fig 2a), observa-se picos em 12,5 e 25o (20), que são típicos de produtos lamelares de óxidos de Mn e são referentes aos planos (001) e (002) da fase lamelar birnessita (PDF 0431456) com sistema monoclínico e grupo espacial $\mathrm{C} 2 / \mathrm{m}$ e distância de $7 \AA$ entre as camadas. Na Fig. 2 b, pode-se confirmar a expansão da estrutura birnessita, e consequentemente, transformação para Cabuserita (PDF 032-1128). Os três primeiros picos mais intensos são referentes aos planos (001), (241) e (262), com distância entre as camadas de 9,6 Å e sistema ortorrômbico.

Figura 2: Padrões de DRX das amostras NABIR (a) e IBUS (b).

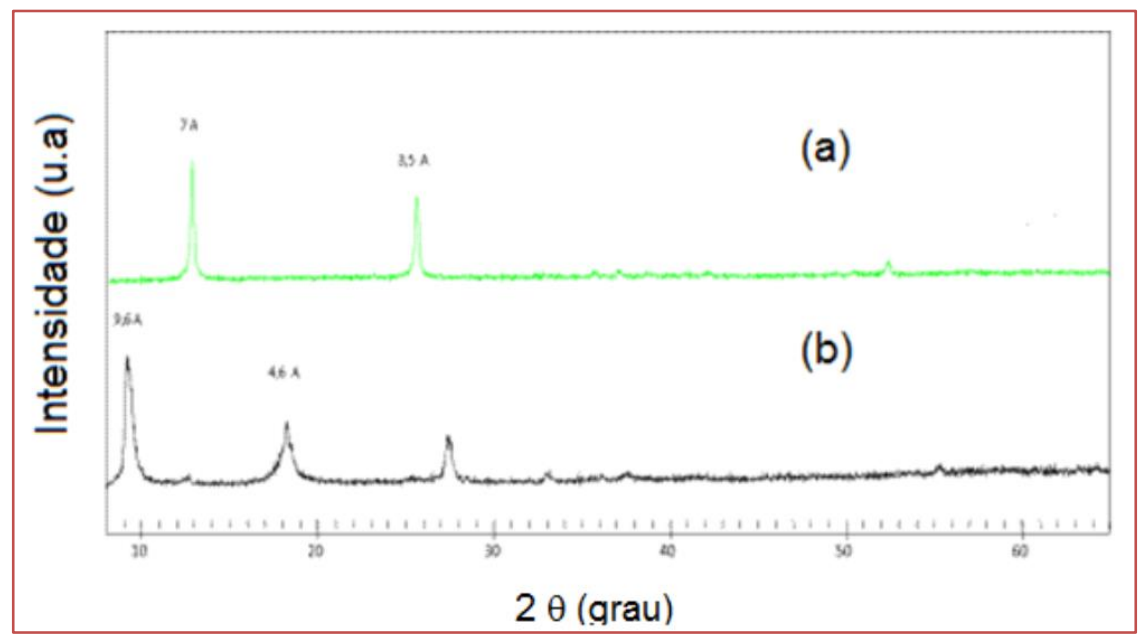

0 espectro de infravermelho FTIR na faixa de 400-800 cm-1 de IBUS é apresentado na Fig. 3. As cinco bandas mais intensas em torno de 715, 695, 661, 565 e $431 \mathrm{~cm}-1$ podem ser assinaladas às vibrações Metal-Oxigênio tanto nos octaedros Mn06, quanto no espaço interlamelar [10]. 
Figura 3: Espectro no infravermelho FTIR de IBUS.

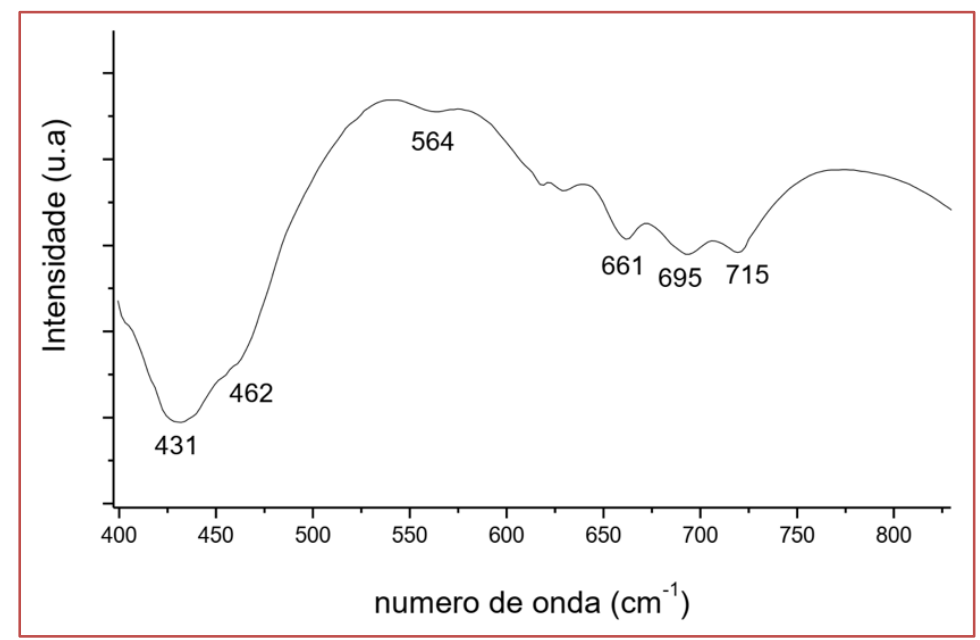

O efeito do tratamento termal na amostra IBUS foi estudado através das curvas TG/DTA e os resultados são apresentados na Fig 4.

Figura 4: Curvas TG/DTA de IBUS.

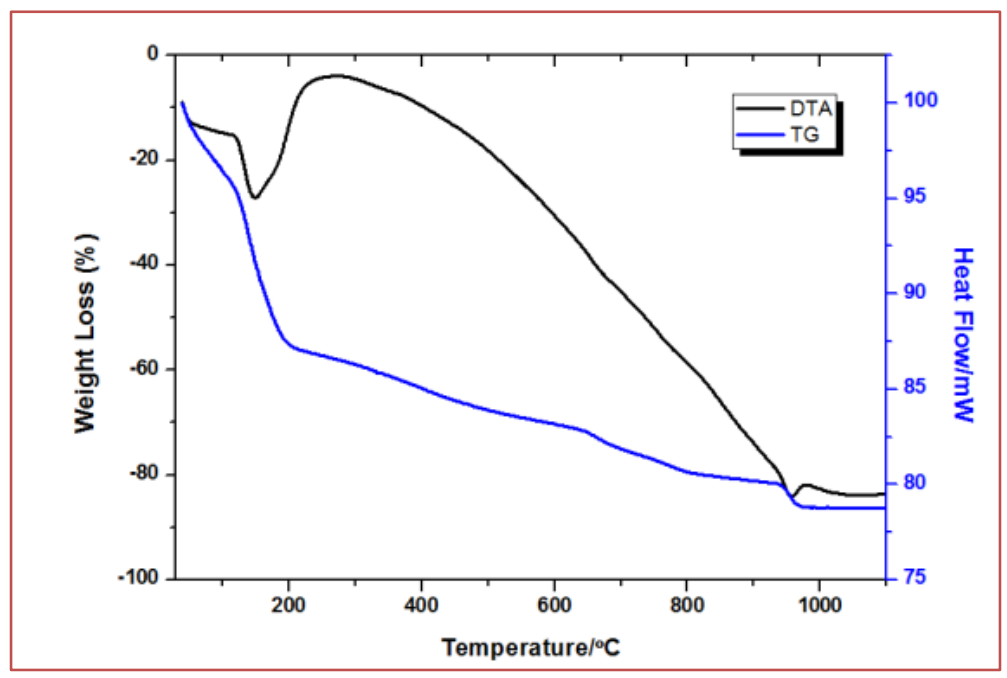

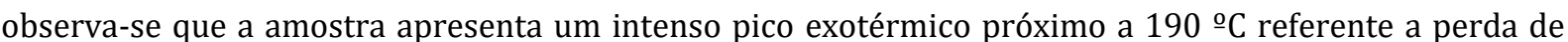
agua adsorvida e interlamelar da estrutura e formação de uma estrutura análoga a Ca-birnessita com distância de 7,15 Å. A perda de água interlamelar se mantém até $860^{\circ} \mathrm{C}$, acima desse intervalo ocorre um segundo evento exotérmico, que se refere a transformação da estrutura lamelar à fase Mn203 [11].

\section{CONCLUSÕES}

Minério de Mn de oxido de Mn pode ser utilizada como matéria-prima para a produção de material lamelar com estrutura Ca-Buserita. 0 produto possui elevada cristalinidade, bandas diagnósticas na espectroscopia de IV (FTIR) em 715, 695, 661, 565 e 431 cm-1 e elevada estabilidade termal.

\section{AGRADECIMENTOS}

Os autores agradecem o suporte financeiro do CNPQ (Universal n. 420169) e Capes (No. 88881.160695) e aos professor Prof. Dr. Marcondes Lima da Costa (UFPA) e Romulo Anglica (UFPA). 


\section{REFERÊNCIAS}

[1] Post, J. E. 1999. Manganese oxide minerals: crystal structures and economic and environment significance.

[2] Proc. Natl. Acad. Sci., 96: 3447-3454. Feng, Q.; Kanoh, H.; Ooi K. Manganese Oxide Porous Crystals. J. Mater.

[3] Chem., v. 9, p. 319- 333, 1998. Suib, S. L. Control of nanometer - scale tunnel sizes of porous manganese oxide octahedral molecular sieve nanomaterials. Adv. Mat., v. 17, p. 805-809, 2005.

[4] Ching, S. et al. Nonaqueous Sol-gel syntheses of microporous manganese oxides. Chem. Mat., v. 14, p. 1292-1299, 2002.

[5] DeGuzman, R.N.; Shen, Y.-F.; Neth, E.J.; Suib, S.L.; O’Young, C.-L; Levine, S.; Newsam, J.M.; "Synthesis and Characterization of Octahedral Molecular Sieves (OMS-2) Having the Hollandite Structure", Chem.Mater., v.6, p.815821, 1994.

[6] FENG, Q.; YANAGISAWA, K.; YAMASAKI, K.; Hydrothermal Soft Chemical Process for Synthesis of Manganese Oxides with Tunnel Structures, J. Porous Mat., v. 5, p. 153-161, 1999.

[7] BACH, S. et al. Birnessite manganese dioxide synthesized a sol-gel process: a new rechargeable cathodic material for lithium batteries. Electrochimica Acta, v. 36, p. 1595-1603, 1991.

[8] AL-ATTAR, L.; DYER, A.; Sorption behaviour of uranium on birnessite, a layered manganese oxide, J. Mater. Chem., v. 12, 1381-1386, 2002.

[9] CORNELL, R. M.; GIOVANOLLI, R.; Transformation of hausmannite into birnessite in alkaline media, Clay and Clay Minerals, v. 36, p. 249, 1988.

[10] JULIEN, C. M.; MASSOT, M.; POISIGNON, C.; Lattice vibrations of manganese oxides part i. periodic structures, Spectrochimica Acta Part, v. A 60, p. 689-700, 2004 


\section{Capítulo 17}

Influência da variação dos gases de proteção e parâmetros de soldagem na microestrutura $e$ microdureza do aço SAE 1035 soldado por Processo $M A G$

Perla Alves de Oliveira

Thiago Monteiro Maquiné

Márcia Cristina Gomes de Araújo Lima

Reinaldo de Almeida Rodrigues

José Costa de Macedo Neto

Resumo: 0 processo MAG é um dos processos de soldagem mais utilizados na indústria atualmente. Devido a sua importância na fabricação, caracteriza-se a necessidade de se garantir uma boa qualidade dos cordões de solda, como navios, pontes, máquinas de construção e motocicletas. 0 processo une metais usando o calor intenso gerado por um arco elétrico entre os metais a serem unidos e um fio de enchimento (sólido ou fluxo). 0 objetivo deste trabalho foi avaliar o efeito da alteração nos parâmetros de tensão, corrente elétrica e gases na microestrutura e microdureza do aço SAE 1035. 0 processo de soldagem aplicado nas amostras foi o modo MILF STELL-MAG na posição 4G. A preparação metalográfica foi realizada, seguindo a norma ASTM E3. As observações das microestruturais de cada região da junta soldada foram realizadas em um microscópio óptico (THS - 200 Olympus) e para análise de microdureza utilizou-se um microdurômetro (HM-100 Mitutoyo) com a carga 1,0 kgf o ensaio seguiu a norma ASTM E384 - 11 ambos realizados no Laboratório de Engenharia de Ciências e Materiais da Universidade do Estado do Amazonas (UEA). Para amostra 1 utilizou-se $170 \pm 30 \mathrm{~A} \mathrm{e}$ $100 \%$ CO2, para amostra 2 utilizou-se $175 \pm 30 \mathrm{~A}$ e $100 \%$ CO2 , para amostra 3 utilizouse $180 \pm 30 \mathrm{~A}$ e $100 \%$ CO2, para amostra 4 utilizou-se $190 \pm 30 \mathrm{~A}$ e $100 \% \mathrm{CO} 2$ e para amostra 5 utilizou-se $230 \pm 30 \mathrm{~A}$ e $100 \%$ Ar. Pela análise de microdureza observou-se que há um aumento na ZTA com o aumento da corrente utilizando o gás CO2. A soldagem utilizando o gás Argônio observou-se uma redução na microdureza da ZTA. Observa-se que houve um aumento da colônia de perlita do metal de base próximo a ZTA com o aumento da corrente elétrica. Houve um aumento da ZTA com o aumento da corrente elétrica.

Palavras-chave: Aço SAE 1035. Processo de Soldagem. Microestrutura. Microdureza. Proteção de gases 


\section{INTRODUÇÃO}

Devido a grande aplicação do aço SAE 1035, cada vez mais se fazem necessário conhecer melhor o comportamento mecânico da solda nesse tipo de material e em especial as microestruturas formadas em diferentes processos de soldagem, já que o tipo de processo de soldagem tem efeito significativo na microestrutura. A solda altera as características criando regiões com variadas microestruturas que alteram o comportamento mecânico do material, portanto, deve ser dada atenção redobrada para estas regiões, uma vez que se sabe que as microestruturas com as características adequadas, nestas regiões, garantem a resistência do produto final, além de garantir o pleno funcionamento mecânico do mesmo dentro de um determinado período de tempo estipulado pelo fabricante sem que ocasione algum tipo de ruptura ou deformação. A escolha do processo de soldagem envolve basicamente quatro fatores: projeto da junta, espessura do material, natureza do material a ser soldado, custo de fabricação [1].

Os materiais de base (MB), quando submetidos ao processo de soldagem a arco, dão origem às juntas soldadas. A junta soldada é composta de regiões distintas, conhecidas como zona de fusão (ZF), zona afetada pelo calor (ZAC) e a zona de ligação (ZL), que é a interface entre a ZF e a ZAC [2].

0 gás de proteção utilizado no processo $\mathrm{MIG} / \mathrm{MAG}$ afeta não somente as propriedades da solda, mas determina o formato do cordão de solda. Dependendo do tipo de transferência metálica, o gás de proteção interage com maior ou menor intensidade com o arame eletrodo, podendo alterar as propriedades mecânicas e principalmente a qualidade do cordão solda. 0 dióxido de carbono (CO2) é o mais barato entre os tipos de gases de proteção de solda e mais utilizado na soldagem MIG/MAG em aço com transferência por curto-circuito. $0 \mathrm{CO} 2$ se dissocia no arco para formar $\mathrm{CO}$ e $\mathrm{O}$ e o efeito global é o de gerar uma proteção oxidante. Exibe características de gás inerte em temperatura ambiente, não reagindo com outros elementos, mas é um gás ativo nas temperaturas de soldagem [3].

De acordo com [4], o argônio (Ar) é um gás inerte com baixo potencial de ionização, baixo potencial de oxidação e baixa condutividade térmica, a alta densidade do argônio em comparação com os outros gases (1,38 em relação ao ar) promove uma maior eficiência de proteção, porque o argônio facilmente substitui o ar em torno da solda. Por ser um gás inerte a proteção à base de argônio promove retenção de elementos de liga no cordão de solda, deixando o cordão de solda livre de inclusões, melhorando as propriedades mecânicas. Além disso, facilita a abertura do arco, melhora a estabilidade em baixas correntes, além de permitir transferência "spray".

A qualidade do cordão de solda conseguido pelos processos MIG/MAG é influenciada por alguns parâmetros, tais como intensidade de corrente, tensão e comprimento do arco, velocidade de soldagem, "stick-out", gases de proteção, diâmetro do eletrodo e posição da tocha, seus tipos e vazão [5].

Durante o processo de soldagem, os materiais envolvidos podem sofrer várias alterações em suas microestruturas e propriedades mecânicas, que influenciam em muito o desempenho e comportamento da peça ou equipamento. Desta forma, este trabalho teve como objetivo realizar um estudo da microestrutura e da microdureza, analisando o metal base, zona afetada pelo calor e zona de fundida do aço SAE 1035 submetido a diferentes parâmetros de soldagem MAG e variações dos gases de proteção CO2 e Ar.

\section{MATERIAIS E MÉTODOS}

\subsection{MATERIAIS}

O metal base SAE 1035 tem a característica de um aço médio teor de carbono com aplicações variadas como eixos, pinos, alavancas e molas de baixa solicitação, indicado para forjamento com boa resposta para têmpera. Tratamento adotado foi a austenitização a $900^{\circ} \mathrm{C}$, têmpera com água com forte agitação.

\subsection{COMPOSIÇÃO QUÍMICA E PROPRIEDADES MECÂNICAS}

Chapa SAE 1035 com garantia de composição química e propriedades mecânicas conforme a tabela 1, classificada pela Norma da SAE 1035 (Society of Automotive Engineers - EUA). 
Tabela 1. Composição Química e Propriedades Mecânicas

\begin{tabular}{|c|c|c|c|}
\hline ELEMENTO & COMPOSIÇÃO & Densidade & $7,87 \mathrm{~g} / \mathrm{cm}^{3}$ \\
\hline Carbono (C) & 0,31 a 0,38 & Limite de Escoam. & $550 \mathrm{Mpa}$ \\
\hline Manganês (Mn) & 0,60 a 0,90 & Resistencia Tração & $620 \mathrm{Mpa}$ \\
\hline Silício (Si) & 0,50 máx. & Alongamento & $24 \%$ mínimo \\
\hline Fósforo (P) & 0,04 máx. & Dureza Brinell & 179 \\
\hline Enxofre (S) & 0,05 máx. & Elasticidade & $190 \mathrm{GPa}$ \\
\hline Ferro (Fe) & O que sobra & & \\
\hline
\end{tabular}

Fonte: Fabricante AÇOVISA

O metal de adição usado foi o BME-04 AWS A5. 18 ER70S - 6, na tabela 2 mostra a composição química do arame em porcentagem (\%).

Tabela 2. Composição Química do Arame BME-04 AWS A5. 18 ER70S-6

\begin{tabular}{|c|c|}
\hline \multicolumn{2}{|c|}{ Composição Química do Arame \% } \\
\hline Carbono (C) & 0,06 a 0,15 \\
\hline Manganês (Mn) & 1,4 a 1,85 \\
\hline Silício (Si) & 0,8 a 1,15 \\
\hline Fósforo (P) & 0,025 máx \\
\hline Enxofre (S) & 0,0035 máx \\
\hline Cobre (Cu) & 0,5 máx \\
\hline \multicolumn{2}{|c|}{ Fonte: Fabricante Belgo Bekaert Arames } \\
\hline
\end{tabular}

\subsection{PARÂMETROS DE SOLDAGEM E GASES DE PROTEÇÕES}

0 processo de soldagem aplicado nas amostras foi o modo MILF STELL-MAG numa aplicação real na indústria do polo de Manaus, na tabela 3 estão dispostos os parâmetros de soldagem e gases proteção aplicada em cada amostra.

Tabela 3. Parâmetros de soldagem aplicada nas amostras

\begin{tabular}{|c|c|c|c|c|c|c|c|}
\hline Amostra & Gás & Amperagem & Voltagem & Stick- out & Vazão & Posição & Ângulo \\
\hline Peça 1 & $100 \%$ CO2 & $170 \pm 30 \mathrm{~A}$ & $23 \pm 3 V$ & $15 \pm 3 \mathrm{~mm}$ & $17 \pm 3 \mathrm{~L} / \mathrm{min}$ & $4 \mathrm{G}$ & $18^{\circ}$ \\
\hline Peça 2 & $100 \%$ CO2 & $175 \pm 30 \mathrm{~A}$ & $23 \pm 3 V$ & $15 \pm 3 \mathrm{~mm}$ & $17 \pm 3 \mathrm{~L} / \mathrm{min}$ & $4 \mathrm{G}$ & $18^{\circ}$ \\
\hline Peça 3 & $100 \%$ CO2 & $180 \pm 30 \mathrm{~A}$ & $24 \pm 3 V$ & $15 \pm 3 \mathrm{~mm}$ & $17 \pm 3 \mathrm{~L} / \mathrm{min}$ & $4 G$ & $18^{\circ}$ \\
\hline Peça 4 & $100 \%$ CO2 & $190 \pm 30 \mathrm{~A}$ & $24 \pm 3 V$ & $15 \pm 3 \mathrm{~mm}$ & $17 \pm 3 \mathrm{~L} / \mathrm{min}$ & $4 G$ & $18^{\circ}$ \\
\hline Peça 5 & $100 \% \mathrm{Ar}$ & $230 \pm 30 \mathrm{~A}$ & $24 \pm 3 V$ & $15 \pm 3 \mathrm{~mm}$ & $17 \pm 3 \mathrm{~L} / \mathrm{min}$ & $4 \mathrm{G}$ & $18^{\circ}$ \\
\hline
\end{tabular}

Fonte: Autores 


\subsection{PREPARAÇÃO DO CORPO DE PROVA PARA AS ANÁLISES METALOGRÁFICA}

A preparação metalográfica foi realizada, seguindo a norma ASTM E3, as amostras foram seccionadas no aço SAE 1035 trefilado a frio, numa cortadora metalográfica de marca Arotec, com disco abrasivo. Após esta etapa, as amostras foram embutidas, adotou-se resina fenólica em pó (Arotec) e a embutidora metalográfica (Arotec, PRE $30 \mathrm{Mi}$ ), esta etapa teve como finalidade facilitar o manuseio das amostras durante a preparação e ainda a função de preservar as bordas das amostras, ajudando a evitar o abaulamento. Em seguida, as amostras foram submetidas ao processo de desbaste, neste processo utilizamos uma lixadeira metalográfica (Prazis, Modelo ALM4) e lixas de carbeto de silício com diferentes granulações 120 a 1200 mesh. Para o polimento os corpos de prova foram submetidos ao uso de pasta abrasiva de $0,3 \mu \mathrm{m}$ e $0,05 \mu \mathrm{m}$, e posteriormente ao ataque químico por imersão com Nital $3 \%$ por 5 segundos.

As observações das microestruturas de cada região da junta soldada foram realizadas em um microscópio óptico (THS - 200 Olympus), no Laboratório de Engenharia de Ciências e Materiais da Universidade do Estado do Amazonas (UEA), sendo elas: metal de base; zona termicamente afetada e zona fundida. Para análise de microdureza utilizou-se um microdurômetro (HM-100 Mitutoyo) com a carga 1,0 kgf. 0 ensaio seguiu a norma ASTM E384 - 11. Adotando-se os corpos de prova usados na metalografia.

\section{RESULTADOS E DISCUSSÃO}

Figura 1 expõe a região que foram feitas as medidas de dureza na secção transversal da junta soldada, e em todas as amostras foi possível observado o mesmo aspecto que a ZTA contornou o metal de solda, dando assim um aspecto mais grosseiro nas suas estruturas e na figura 2 são observados o comportamento das curvas de dureza x profundidade comparativa entre juntas soldadas com $\mathrm{CO} 2$ e Argônio das amostras realizadas. Pelos valores de dureza figura 2 na faixa de $0,30 \mathrm{~mm}$ de distância da ZTA, logo após a zona de ligação para juntas soldadas com CO2, foram obtidas durezas entre 400 a 520 $\mathrm{HmV}$ ( 40 a 52HRC), e as amostra que apresentaram similaridades nos seus valores foram as peças 1 e 3 . Já em um intervalo maior, como o 0,50mm e 0,70 mm, a junta solda com Argônio, alcançamos valores de dureza compreendendo de 270 a $290 \mathrm{HmV}$ (27 a 29 HRC). Pois, a adição do CO2 como gás de proteção não altera a taxa de deposição e geometria do cordão de solda, e ainda elevando a taxa de diluição e valores de dureza do metal de solda, devido o mesmo ter um alto poder oxidante e alta condutividade térmica, possibilitando assim um resfriamento mais lento do material, quando comparado com o argônio, estas observações estão em concordância com os obtidos por [6].

Figura 1. Região de medida da dureza da junta soldada (Autores, 2018)

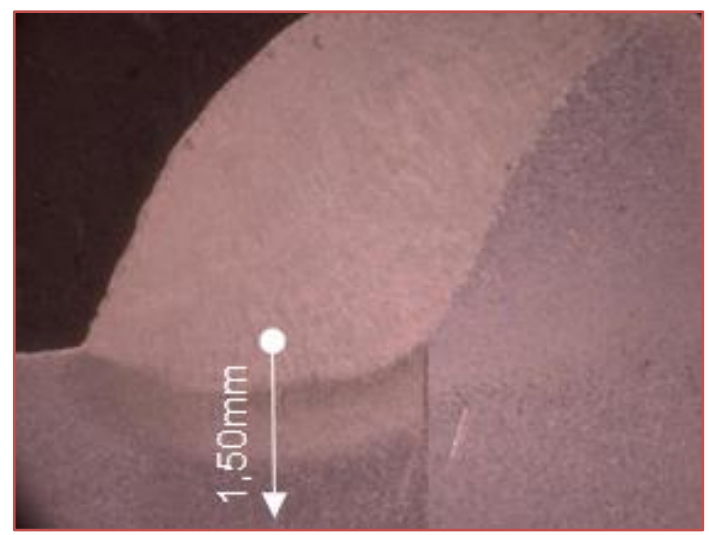


Figura 2. Curvas de dureza x profundidade comparativa entre juntas soldadas com CO2 e Argônio (Autores, 2018)

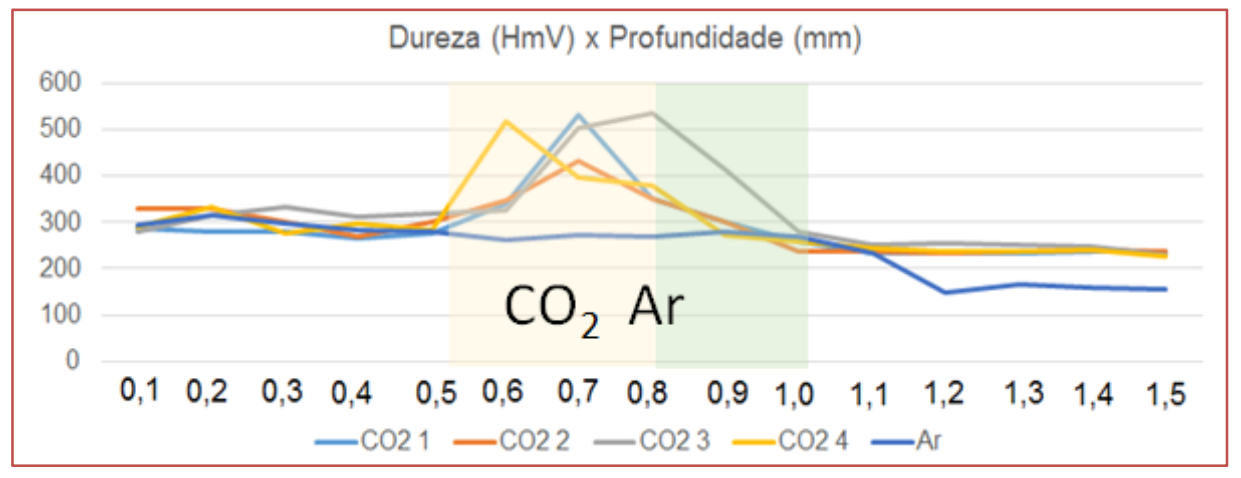

Nas análises metalográficas da junta soldada utilizando o gás argônio na figura 3 mostra secção da junta solda com Argônio e as figuras 4 e 5 são as microestruturas das regiões de ligação e recristalização respectivamente, observamos uma maior extensão da ZTA, este comportamento se deve ao fato de o gás de proteção ter como características o baixo potencial de ionização, oxidação e condutividade de térmica, e ainda tais aspectos do argônio alteram a sua microestrutura, e neste trabalho foi encontra a bainita e perlita, e estas refletem no comportamento de microdureza, pois o gás de proteção, também influência na formação geométrica do cordão de solda, estas características também foram relatadas por [7]. Outra observação que é pertinente é a amperagem empregada, na amostra 5, pois esta é entorno de 50 a $90 \mathrm{~A}$ maior, usando a margem de erro de $\pm 30 \mathrm{~A}$ empregada no trabalho, pois este fator influência diretamente nas propriedades mecânicas.

Figura 3. Secção da junta solda com Argônio (Autores, 2018)

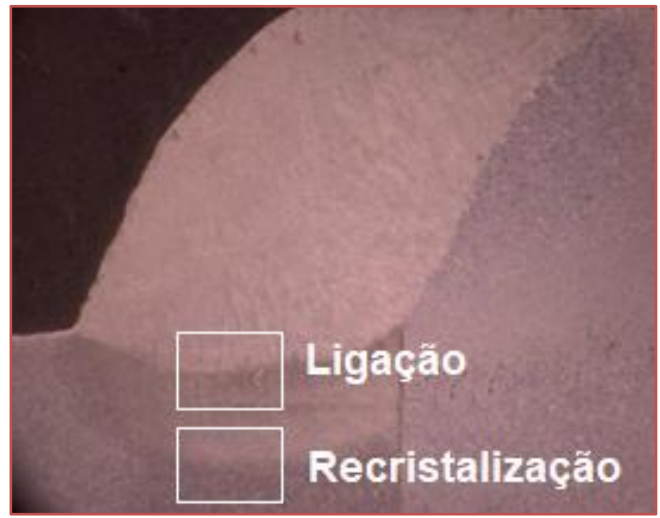

Figura 4. Microestrutura da região de ligação solda com Argônio (Autores, 2018)

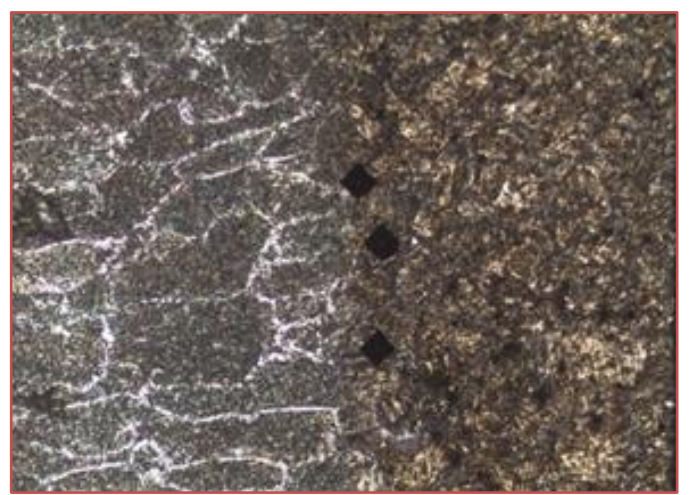


Figura 5. Microestrutura da região de recristalização solda com Argônio (Autores, 2018)

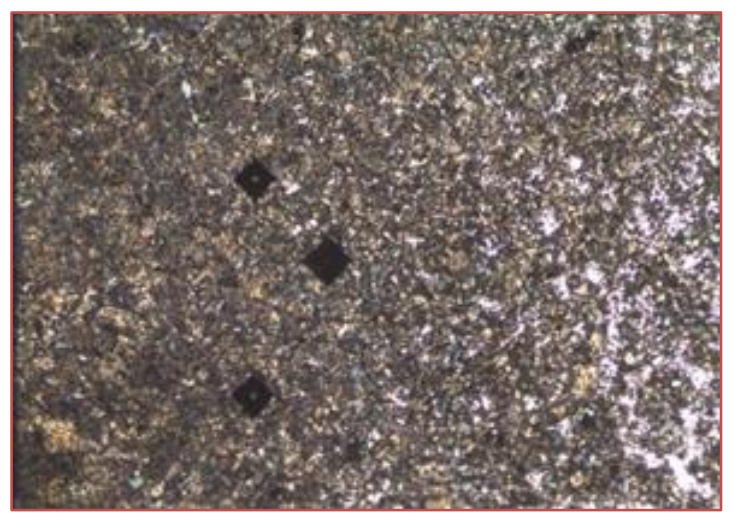

Na figura 6 mostra secção da junta solda com C02. Já nas figuras 7 e 8 mostram microestrutura das regiões de ligação e recristalização respectivamente, que pelas observações constatamos que não alterações significativas na ZTA, quando comparado com a amostra feita pelo gás de proteção de argônio, por ferritas e maternsita, estas microestruturas influenciam diretamente nas propriedades mecânicas, originando o tamanho de grãos menores, refletindo assim na microdureza. Na faixa estudada por este trabalho, os menores valores de amperagens soldados usando o CO2 como gás de proteção resultaram em soldas com microestruturas mais refinadas, podendo ser provenientes de maiores taxas de resfriamento, o que foi associado à maior condutividade térmica do $\mathrm{CO} 2$ em relação ao $\mathrm{Ar}$, pois a faixa de amperagem altera de forma significativa a taxa de deposição, geometria de solda e fração volumétrica da microestrutura, e tais observações resultaram em valores de microdurezas próximos entre uma amostra e outra.

Figura 6. Secção da junta solda com CO2 (Autores, 2018)

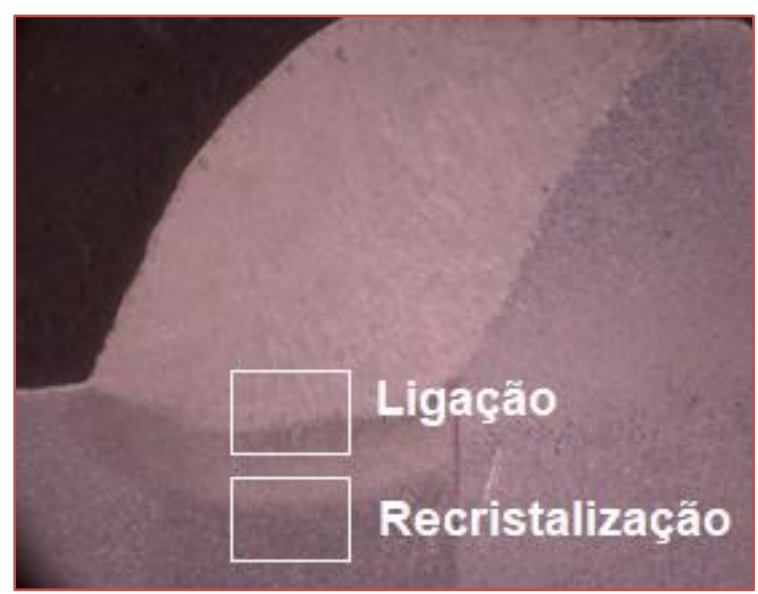


Figura 7. Microestrutura da região de ligação solda com CO2 (Autores, 2018)

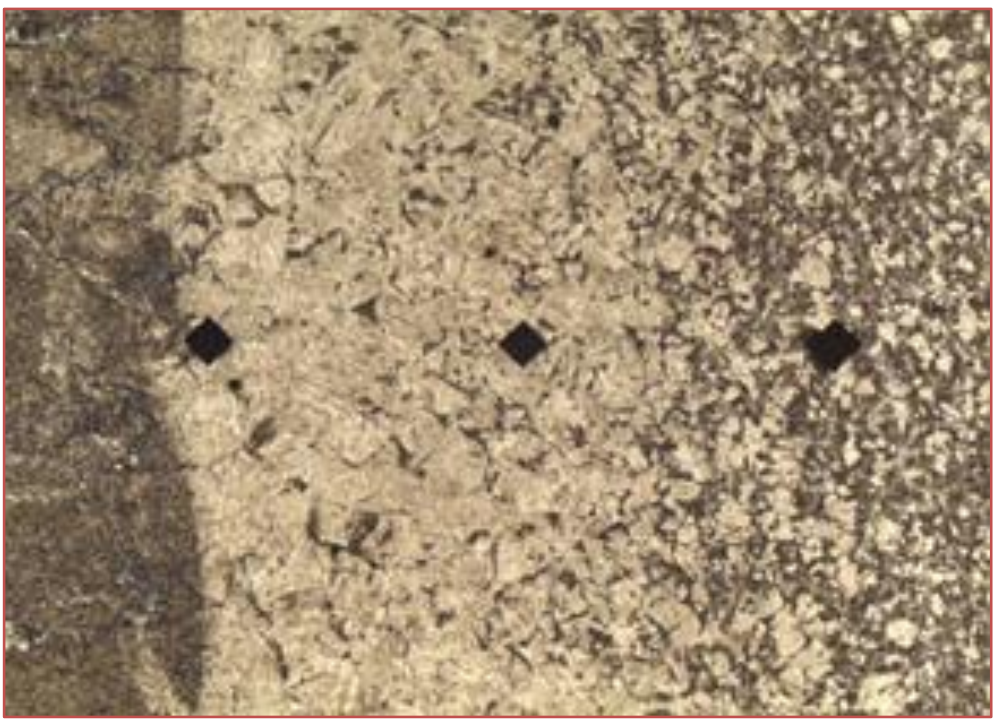

Figura 8. Microestrutura da região de recristalização solda com CO2 (Autores, 2018)

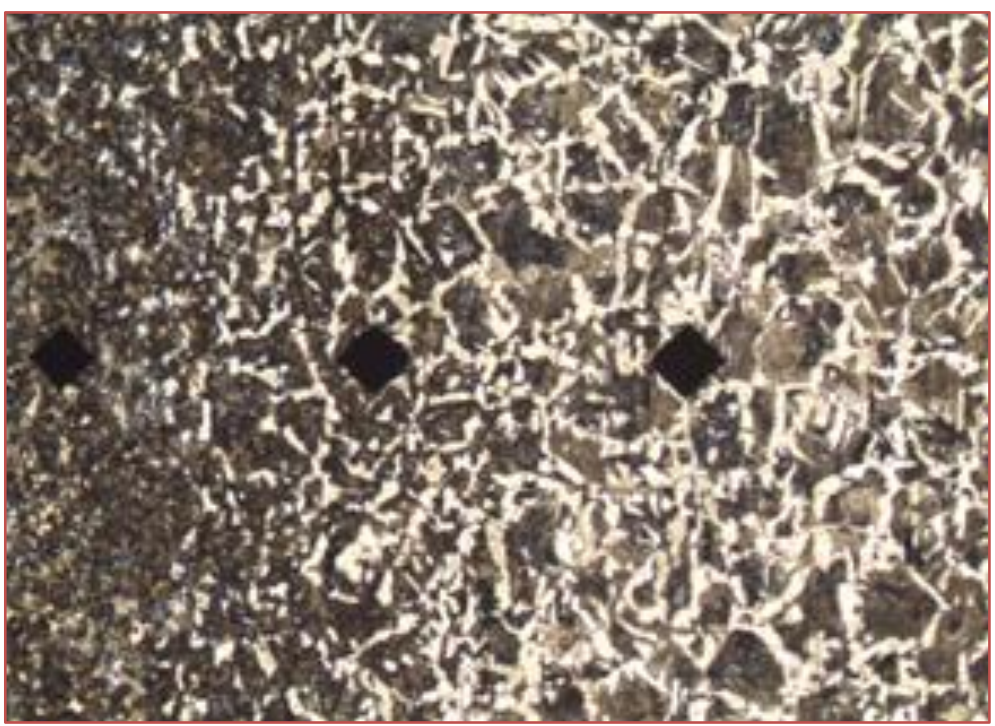

\section{CONCLUSÕES}

Observamos que os gases de proteção adotados alteram de formas significativas as propriedades das peças, pois a diferença em torno de aproximadamente $130 \mathrm{HmV}$ o que pode render $23 \mathrm{HRC}$, entre as amostras aferidas, irão ditar se é viável ou não processar a solda usando $\mathrm{CO} 2$ ou Ar, com determinadas condições, levando em conta a vazão e a amperagem da soldagem, constatamos ainda que o dióxido de carbono não alterou a taxa de deposição da solda, geometria do cordão de solda, a fração volumétrica das microestrutura e ainda elevou a os valores de durezas do material, enquanto, o argônio provou que não é um bom gás de proteção no processo de soldagem, já que as suas características físico-químicas são bem diferentes que o $\mathrm{CO} 2$, tais aspectos influenciaram de forma substancial da dureza obtida do material e que ainda se refletiu na alteração da zona do cordão de solda. 


\section{REFERÊNCIAS}

[1] Modenesi P. J., Marques Paulo Villani, Bracarense Alexandre Queiroz. Soldagem: fundamentos e tecnologias. Belo Horizonte: Ed. UFMG; 2017.

[2] Barros P. M. Metalurgia da Soldagem I. São Paulo: Faculdade de Tecnologia de São Paulo, Fatec/UNESP, 2002.

[3] Canto M. A. A. Influência dos gases de proteção empregados no processo MIG/MAG sobre as propriedades mecânicas do metal de solda. Dissertação UFRGS, p. 02-06, 1991.

[4] Couto J. G. V., Pessoa A. A. Processo C02, em solda versus misturas de argônio e dióxido de carbono. Separata da Revista Engenharia Industrial, p. 01-08, 2000.

[5] Bracarense A., Pereira U. A soldagem GMAW. Revista da Soldagem, nº 05, p. 01-12, 2005.

[6] Moreira A. F. M838i Influência da atmosfera protetora no cordão de solda obtido através dos processos de soldagem GMAW e FCAW. Ilha Solteira; 2008; p. 146.

[7] Figuerôa, D.W. Estudo da Influência do Teor de CO2 em Misturas de Ar + CO2 e do Metal de Adição na Soldagem Híbrida Laser - Gmaw Maw em Aço Estrutural. 22 CBECIMAT - Congresso Brasileiro de Engenharia e Ciência dos Materiais; 2016. 


\section{Capítulo 18}

Efeito da incorporação da enzima celulase e dos fatores abióticos na biodegradação aeróbia do PEBD

\section{Luisa Alban}

\section{Gabriela Messias Miranda}

Jéssica Pereira Pires

Gabriela Lagranha de Souza

Flávia Stürmer de Fraga

Rogério Vescia Lourega

Rosane Angélica Ligabue

Jeane Estela Ayres de Lima

Resumo: 0 consumo excessivo de plásticos e seu descarte inadequado no meio ambiente têm gerado muita preocupação, uma vez que são materiais de difícil degradação e que tem causado poluição em mares, oceanos, etc. Devido a isto, existe grande necessidade de soluções para tentar minimizar este problema. Uma das soluções é transformá-los em materiais biodegradáveis através da inserção de aditivos biodegradantes, os quais podem ser compostos, em sua grande parte, por enzimas, que são proteínas consideradas catalisadores biológicos. Tendo em vista que a adição de biomoléculas aos polímeros sintéticos e a exposição dos mesmos a fatores abióticos (UV e umidade) podem promover a biodegradação, foi produzido um biocompósito de PEBD com 4\% $\mathrm{m} / \mathrm{m}$ da enzima celulase. 0 ensaio de envelhecimento acelerado foi conduzido em uma câmera QUV (QLAB) sob as condições da norma ASTM G154-16 durante $1000 \mathrm{~h}$ (triplicata). A avalição da biodegradação aeróbia em solo foi realizada sob as condições da norma ASTM D5988-12 durante 56 dias a $30{ }^{\circ} \mathrm{C} \pm 2{ }^{\circ} \mathrm{C}$. Amido de milho foi utilizado como controle positivo. Os resultados da respirometria sugerem que a incorporação da celulase promove a biodegradação do PEBD. Ainda que a amostra de PEBD/celulase envelhecida tenha apresentado um comportamento similar à amostra não envelhecida até 51 dias, foi observado uma tendência de aumento na produção de $\mathrm{CO} 2$ a partir do último ponto obtido (56 dias).

Palavras-chave: celulase, intemperismo, PEBD, biodegradação. 


\section{INTRODUÇÃO}

Plásticos são, em sua grande parte, polímeros sintéticos obtidos a partir do petróleo. São materiais que apresentam características muito úteis, como baixa densidade quando comparados a outros materiais sólidos, relação força-peso significativamente alta, boa estabilidade a choques mecânicos, resistência química e a corrosão. Apesar dos plásticos terem influenciado numa grande melhora da qualidade de vida das pessoas, os problemas de poluição ambiental, associados ao consumo excessivo e descarte inadequado, são uma grande preocupação (FARZI et al., 2018). Os plásticos têm se acumulado nos oceanos, solos, fundo do mar e ilhas isoladas desde a década de 50, época em que a produção em massa de produtos plásticos iniciou. Cerca de 13 milhões de toneladas de plásticos são despejados dentro de oceanos de todo o mundo a cada ano, sendo então ingeridos por peixes, aves marinhas e outros organismos. No Brasil, a quantidade de resíduo sólido urbano gerado é em torno de 200.000 toneladas por dia, dos quais $17,7 \%$ se encontram em lixões, $58,1 \%$ em aterros sanitários e $24,2 \%$ em aterros sanitários controlados (SKARIYACHAN et al., 2018). Dentre os plásticos, podemos destacar a grande variedade de polietilenos, sendo que os polietilenos de baixa densidade (PEBD) são amplamente utilizados na produção embalagem e sacolas plásticas, devido às suas características de baixo peso e custo, além da alta durabilidade (MEHMOOD et al., 2016; SKARIYACHAN et al., 2018). O PEBD, entretanto, é um polímero resistente ao ataque de microrganismos (HADDAD et al., 2005).

0 processo de biodegradação de plásticos dentro das condições normais do ambiente é extremamente lento, uma vez que a atuação de microrganismos é fisicamente limitada. Isto ocorre pelo fato de apresentarem alto peso molar e ausência de grupos funcionais em suas estruturas, o que torna este material insolúvel em meios aquosos (RESTREPO-FLÓREZ et al., 2014, PEIXOTO et al., 2017). A degradação dos polímeros pode ocorrer de forma abiótica e biótica. Normalmente a abiótica ocorre antes da biodegradação, e pode iniciar tanto termicamente, hidroliticamente ou pela exposição à radiação ultravioleta (UV-fotodegradação), sendo degradada, primeiramente, a superfície do material, ficando exposta e disponível ao ataque químico e/ou enzimático (GEWERT et al., 2015). A inserção de aditivos comerciais como pró-degradantes ou biodegradantes, como por exemplo amido, celulose e enzimas já foi descrita na literatura como possível alternativa para conferir biodegradabilidade a poliolefinas (OJEDA et al., 2009; AMMALA et al., 2011; NOWAK et al., 2011; RESTREPO-FLÓREZ et al., 2014; SEN E RAUT, 2015; COSTA et al., 2015).

A incorporação de biomoléculas (como enzimas e peptídeos) vem sendo explorada como abordagem alternativa para degradação de PEBD, uma vez que as mesmas podem modificar a cadeia deste plástico (SKARIYACHAN et al., 2018). Estudos indicam que enzimas são capazes de degradar PEBD (MEHMOOD et al., 2016) devido a clivagem das cadeias do polímero em monômeros (ESMAELLI et al., 2013). JANCZAK et al. (2018) estudaram a biodegradação de PLA e PET por microrganismos da rizosfera do solo. Eles utilizaram cepas das bactérias Arthrobacter sulfonivorans e Serratia plymuthica, as quais foram isoladas da rizosfera da planta S. viminalis, crescendo em aterros sanitários de cinzas e de resíduo municipal, e cepas dos fungos ectomicorrizais Clitocybe sp. e Laccaria laccata foram isolados de ambientes antropologicamente degradados. As cepas foram capazes de produzir enzimas hidrolíticas como amilases, celulases e lipases. Além disso, a degradação dos materiais foi mais efetiva no solo que continha $40 \%$ de vermiculita enriquecido com enzimas como celulases, amilases, fosfatases e ácidos húmicos. A celulase é uma enzima multicomponente produzida principalmente por fungos, bactérias e protozoários (ZHANG et al., 2015), capaz de catalisar reações de quebra (AHIRWAR et al., 2017), se mostrando como uma ferramenta interessante no estudo da biodegradação de polímeros, como o polietileno. Portanto, a avaliação do comportamento de materiais plásticos após a incorporação de biomoléculas frente a fatores abióticos é de grande interesse. Neste sentido, o objetivo deste trabalho foi avaliar o comportamento de biodegradação de PEBD com incorporação da enzima celulase antes e após o envelhecimento acelerado deste compósito.

\section{MATERIAIS E MÉTODOS}

A produção do biocompósito de PEBD/enzima celulase (PEC) foi conduzida pela adição de 4\% em massa da Enzima Celulase (produzida pelo fungo Aspegillus Niger; Sigma Aldrich) ao PEBD (PB608 da Braskem), em um misturador Rheomix OS Haake acoplado a unidade motriz Polylab OS Rheodrive 7 da Thermo Scientific, sob as condições de $60 \mathrm{rpm}$, temperatura de $150^{\circ} \mathrm{C}$ durante 7 minutos. Filmes de PEBD puro e de PEC foram preparados em uma prensa hidráulica da marca Marconi, com capacidade de 15 toneladas. Os filmes com, aproximadamente, $0,2 \mathrm{~mm}$ de espessura foram obtidos por prensagem entre placas de aço revestidas de teflon, na temperatura de $110^{\circ} \mathrm{C}$ e uma carga de 3 toneladas por 2 minutos. 


\subsection{ENSAIO DE ENVELHECIMENTO ACELERADO}

Para o ensaio de envelhecimento acelerado da amostra PEC, utilizou-se uma Câmara de Envelhecimento Acelerado QUV spray (QLAB) sob as condições do Ciclo 1 da ASTM G154-16. Os filmes produzidos de PEC (95 mm x $65 \mathrm{~mm}$ ) foram irradiados com lâmpadas UVA (340 nm) provendo uma irradiância de 0,89 $\mathrm{W} / \mathrm{cm} 2$ com ciclos intervalados de $8 \mathrm{~h}$ de radiação e temperatura de $60^{\circ} \mathrm{C}$ e $4 \mathrm{~h}$ com spray de água potável, a $40^{\circ} \mathrm{C}$ e umidade relativa de $50 \%$. As amostras foram expostas durante $1000 \mathrm{~h}$ e em triplicata, resultando em amostras denominadas PEC 1000h.

\subsection{CARACTERIZAÇ̃̃O}

Antes e após o ensaio o envelhecimento acelerado, as amostras foram caracterizadas em relação à degradação térmica e às características estruturais conforme seguem os itens, respectivamente:

Análise Termogravimétrica (TGA): a avaliação da estabilidade térmica das amostras foi realizada em equipamento SDT, modelo Q600 (TA Instruments) utilizando taxa de aquecimento de $10{ }^{\circ} \mathrm{C} / \mathrm{min}$, da $30{ }^{\circ} \mathrm{C}$ até $600^{\circ} \mathrm{C}$ sob atmosfera de gás nitrogênio. A análise foi realizada em triplicata.

Espectroscopia de Infravermelho com Transformada de Fourier (FTIR): a análise de espectroscopia de infravermelho foi realizada a fim de investigar a presença de grupos funcionais na estrutura molecular do polímero antes e após envelhecimento. Para esta análise utilizou-se o equipamento Perkin Elmer Instruments Spectrum One FT-IR Spectrometer e a aquisição do espectro foi feita com o acessório de amostras UATR (acessório de refletância atenuada total universal) no intervalo de número de onda de 4000 a $650 \mathrm{~cm}-1$.

\subsection{ENSAIO DE BIODEGRADAÇÃO}

O ensaio de biodegradação aeróbia do PEC foi conduzido durante 56 dias em estufa microbiológica com temperatura controlada de $30^{\circ} \mathrm{C} \pm 2{ }^{\circ} \mathrm{C}$. A avaliação da biodegradação foi realizada segundo as condições

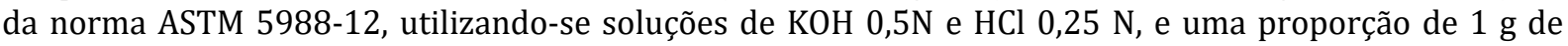
amostra para $500 \mathrm{~g}$ de solo (mistura em três partes iguais de areia, terra vermelha e esterco bovino). A fim de avaliar a qualidade do solo foi utilizado um sistema com controle positivo CP (amido de milho), bem como um sistema com PEC não envelhecido, para fins de comparação. PEBD puro foi utilizado como controle negativo (CN). Análise elementar dos materiais foi realizada em um Analisador Elementar TruSpec CHN da LECO, para quantificar o percentual de carbono de cada amostra e calcular o CO2 teórico produzido por meio da estequiometria das reações envolvendo as Equações 1, 2 e 3. Nas Equações 4, 5 e 6 são apresentadas as fórmulas que levam ao cálculo do percentual de biodegradação, onde x é o volume de $\mathrm{HCl}$ utilizado na titulação e y é a massa de carbono da amostra. PEC e PEC envelhecido foram considerados os materiais de teste (MT), e o sistema sem a presença de CP, CN e MT foi denominado de branco (B).

$$
\begin{aligned}
& \mathrm{C}+\mathrm{O}_{2} \rightarrow \mathrm{CO}_{2} \\
& 2 \mathrm{KOH}+\mathrm{CO}_{2} \rightarrow \mathrm{K}_{2} \mathrm{CO}_{3}+\mathrm{H}_{2} \mathrm{O} \\
& \mathrm{KOH}+\mathrm{HCl} \rightarrow \mathrm{KCl}+\mathrm{H}_{2} \mathrm{O}
\end{aligned}
$$

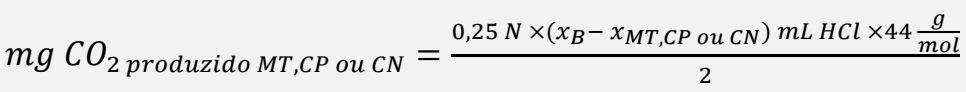

$$
\begin{aligned}
& \mathrm{mgCO}_{2} \text { teórico }=\frac{y \times 44 \frac{\mathrm{g}}{\mathrm{mol}}}{12 \frac{\mathrm{g}}{\mathrm{mol}}} \\
& \% \text { Biodegradação }=\frac{m g \mathrm{CO}_{2} \text { produzido }}{m g \mathrm{CO}_{2} \text { teórico }}
\end{aligned}
$$

\section{RESULTADOS E DISCUSSÕES}

Os resultados referentes a caracterização dos materiais produzidos e ao ensaio de biodegradação estão apresentados nos itens a seguir. 


\subsection{ANÁLISE TERMOGRAVIMÉTRICA (TGA)}

A Figura 1a apresenta os termogramas (TG) e a Figura 1b apresenta as derivadas das curvas termogravimétricas (DTG) para Celulase, PEBD, PEBD modificado com celulase (PEC) e PEC envelhecido por $1000 \mathrm{~h}$ (PEC 1000h). A degradação térmica da celulase e do PEBD ocorreu em uma etapa, entre $250 \mathrm{e}$ $400{ }^{\circ} \mathrm{C}$ e entre $400^{\circ} \mathrm{C}$ e $500^{\circ} \mathrm{C}$, respectivamente. A degradação do PEC apresenta duas etapas de degradação entre 200 e $400{ }^{\circ} \mathrm{C}$ e entre $400^{\circ} \mathrm{C}$ e $500^{\circ} \mathrm{C}$, referentes a degradação da celulase ao PEBD. Este resultado indica que a celulase foi efetivamente incorporada na amostra PEC. A curva de degradação de PEC $1000 \mathrm{~h}$ apresenta uma etapa de degradação de $250^{\circ} \mathrm{C}$ e $500{ }^{\circ} \mathrm{C}$, compreendendo a degradação da enzima e do polímero PEBD. Observa-se, entretanto, um alargamento da primeira etapa de degradação devido aos compostos voláteis gerados durante o processo de envelhecimento.

Figura 1- Curvas de a) TG e b) DTG de Celulase, PEBD e PEC e PEC 1000h.

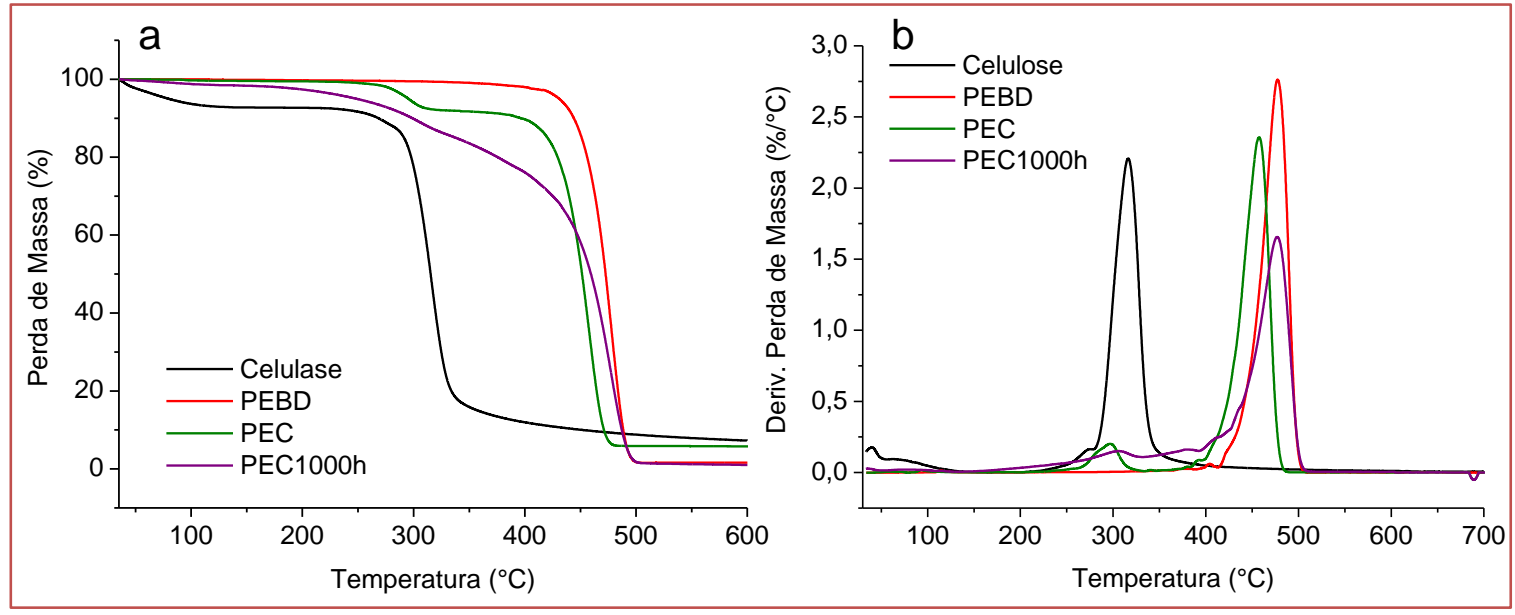

A Tabela 1 apresenta os valores para as temperaturas T10 (a 10\% de perda de massa), T50 (a 50\% de perda de massa), Tmáx1 (temperatura máxima do pico de degradação térmica da celulase) e Tmáx2 (temperatura máxima do pico de degradação térmica do PEBD) obtidas a partir das curvas TG e DTG da Figura 1. Os valores destas temperaturas demonstram o comportamento observado nas curvas da Figura 1.

Tabela 1 - Valores das temperaturas T10, T50, Tmáx1 e Tmáx2 para celulase, PEBD, PEC e PEC 1000h.

\begin{tabular}{|c|c|c|c|c|}
\hline & T10 $\left({ }^{\circ} \mathrm{C}\right)$ & $\mathrm{T} 50\left({ }^{\circ} \mathrm{C}\right)$ & Tmáx $1\left({ }^{\circ} \mathrm{C}\right.$ & Tmáx2 $\left({ }^{\circ} \mathrm{C}\right)$ \\
\hline Celulase & 268,4 & 315,3 & 316,1 & - \\
\hline PEBD & 440,2 & 468,0 & - & 473,5 \\
\hline PEC & 413,7 & 468,2 & 314,3 & 474,3 \\
\hline PEC $1000 \mathrm{~h}$ & 294,5 & 454,74 & 302,1 & 473,7 \\
\hline
\end{tabular}




\subsection{ESPECTROSCOPIA NO INFRAVERMELHO COM TRANSFORMADA DE FOURIER (FTIR)}

A Figura 2 apresenta os espectros de infravermelho obtidos para Celulase, PEBD, PEC e PEC $1000 \mathrm{~h}$.

Figura 2 - Espectros de infravermelho obtidos para Celulase, PEBD, PEC e PEC1000h.

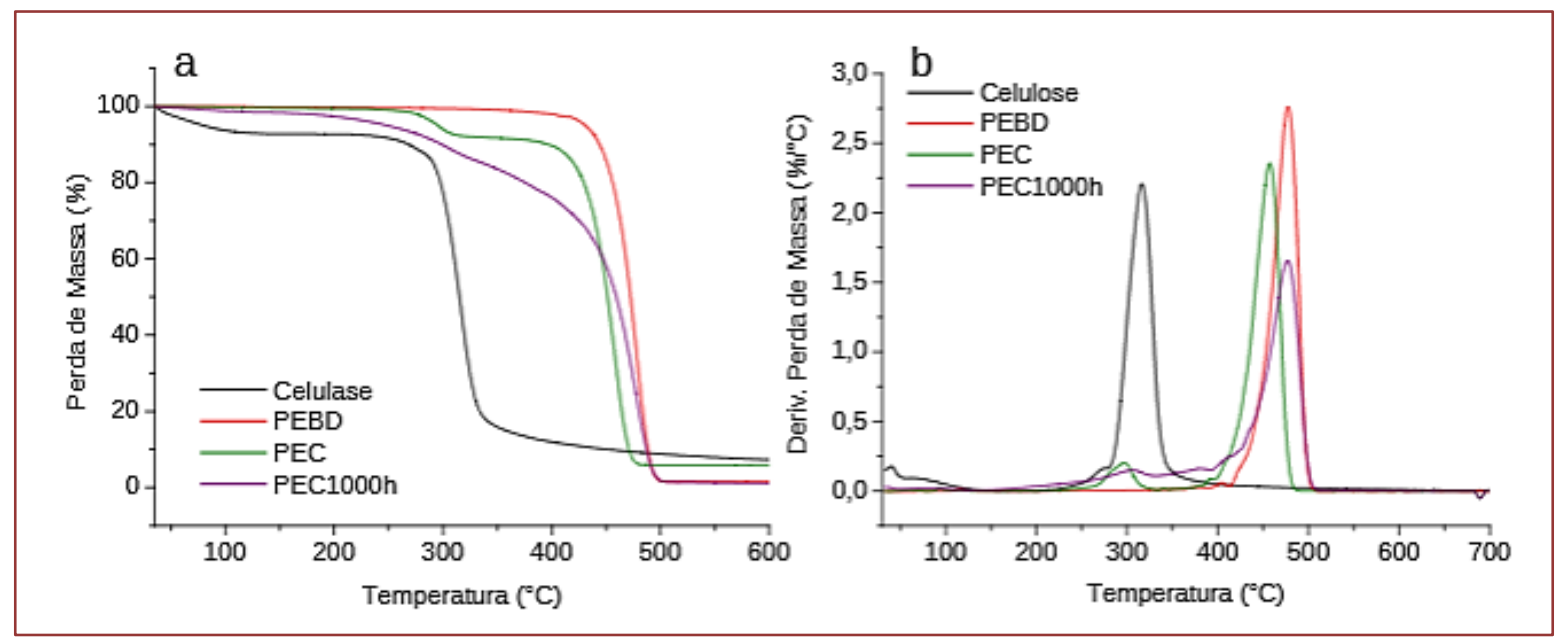

Os espectros obtidos para a amostra de PEBD mostram a presença de bandas em $2916 \mathrm{~cm}-1$ e $2844 \mathrm{~cm}-1$ referentes às deformações axiais de C-H alifáticos; em 1464 cm-1 e 1377 cm-1, correspondentes às deformações angulares simétricas de C-H alifáticos; e em $718 \mathrm{~cm}-1$, correspondente à deformação angular assimétrica no plano ( $\rho \mathrm{CH} 2)$. As mesmas bandas são encontradas nos espectros dos biocompósitos PEC e PEC 1000h.

Para a celulase foi observado a presença de uma banda entre $3000 \mathrm{~cm}-1$ e $3400 \mathrm{~cm}-1$ referentes a grupamentos -NH2 e -OH da enzima (MISHRA et al., 2015; POORAKBAR et al., 2018). 0 pico em $1650 \mathrm{~cm}-1$ é referente a ligação amida (MISHRA et al., 2015). Ainda, foram observadas bandas em $840 \mathrm{~cm}-1,990 \mathrm{~cm}-$ $1,1080 \mathrm{~cm}-1$ e $1152 \mathrm{~cm}-1$, já referenciadas anteriormente na literatura para a celulase (POORAKBAR et al., 2018).

O espectro da amostra PEC mostra o surgimento de uma banda fraca alargada entre $3000 \mathrm{~cm}-1$ e $3400 \mathrm{~cm}$ 1 referente a celulase, também observada em PEC 1000h. 0 sinal fraco pode estar relacionado a baixa concentração de enzima no biocompósito $(4 \% \mathrm{~m} / \mathrm{m})$, chegando próximo ao limite de detecção do equipamento. Já no espectro de PEC $1000 \mathrm{~h}$, foi observado o surgimento de uma banda forte em $1710 \mathrm{~cm}$ 1 , referente ao grupamento $\mathrm{C}=0$ de ácidos carboxílicos e outra em $1182 \mathrm{~cm}-1$ referente ao grupamento C0, ambas provenientes do processo de envelhecimento do PEC (GEWERT et al., 2015; PEIXOTO et al., 2017).

\subsection{ENSAIO DE BIODEGRADAÇÃO}

A Figura 3 apresenta as curvas de biodegradação obtidas para as amostras PEBD (controle negativo), PEC, PEC 1000h e as referências de solo e amido (controle positivo). A curva de PEBD apresentou inicialmente mineralização negativa, comportamento já relatado na literatura para polímeros não biodegradáveis como o PEBD, devido a barreira física oferecida pelo filme polimérico que limita a distribuição de carbono e nutrientes para os microrganismos (CASTRO-AGUIRRE et al., 2017). Entretanto no término do ensaio (56 dias), a biodegradação do PEBD alcançou o valor de 1,1\%, sendo comparável ao que foi reportado na literatura para a biodegradação de PEBD no mesmo tempo de ensaio (ESMAELLI et al., 2013). 
Figura 3 -Curvas de biodegradação de PEBD, PEC, PEC 1000h e referências de solo e amido.

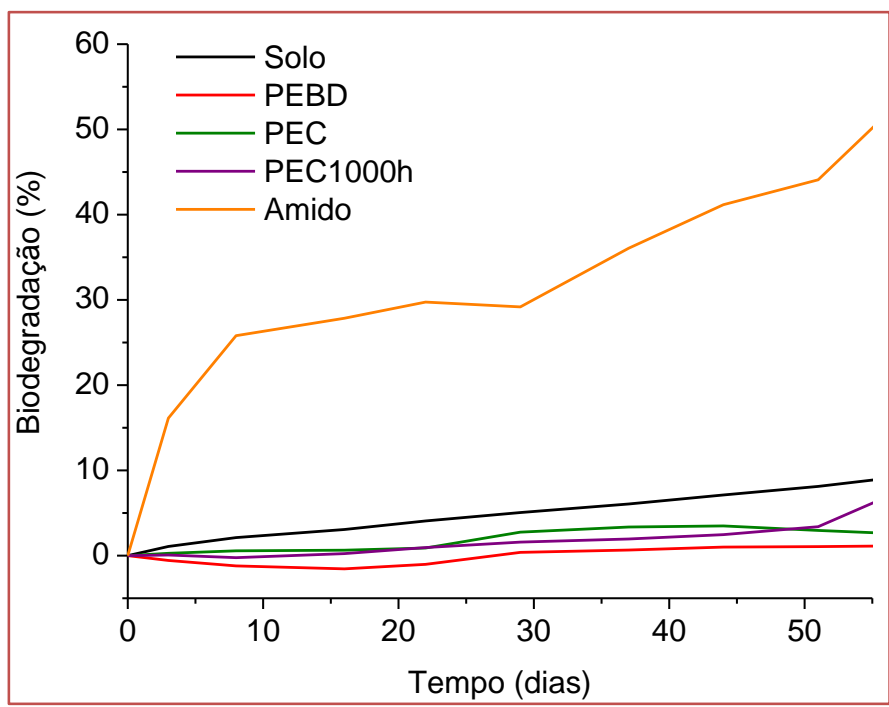

Já as curvas de biodegradação de PEC e PEC 1000h mostram que a adição da enzima na matriz do PEBD facilita a permeação de oxigênio no material e disponibiliza uma melhor fonte de nutrientes para os microrganismos do solo, uma vez que a amostra PEC não apresentou uma mineralização negativa, indicando que a incorporação da celulase pode facilitar a biodegradação do PEBD. Além disso, convém salientar que no término do ensaio estas amostras apresentaram 2,6\% e 6,8\% de biodegradação, respectivamente. Em relação a amostra PEC envelhecida por 1000 h, não foi possível perceber uma variação expressiva na curva de biodegradação em relação a mesma amostra não envelhecida até 50 dias de teste. Porém, a partir deste período, foi observado uma tendência de aumento na produção de CO2, comportamento o qual deve ser melhor estudado.

\section{CONSIDERAÇÕES FINAIS}

Este trabalho avaliou o comportamento de biodegradação de PEBD com incorporação da enzima celulase antes e após o envelhecimento acelerado do mesmo. As curvas de biodegradação indicaram que a incorporação da celulase pode facilitar a biodegradação do PEBD. Mais estudos devem ser conduzidos em relação a amostra envelhecida, porém os resultados obtidos até o momento mostraram que a combinação de PEBD e celulase se apresenta como um objeto de estudo atrativo na biodegradação de polímeros.

\section{AGRADECIMENTOS}

Á CAPES pelas bolsas concedidas (Código de Financiamento 001) e à empresa Brasilata S/A pelas bolsas e materiais concedidos para realização do trabalho.

\section{REFERÊNCIAS}

[1] FARZI, A.; Dehnad, A.; Fotouhi, A. Biodegradation of Polyethylene Terephthalate Waste using Streptomyces species and Kinetic Modeling of the Process. Biocatalysis and Agricultural Biotechnology, v. 17, p. 25-31, 2019.

[2] SKARIYACHAN, S.; Patil, A. A.; Shankar, A.; Manjunath, M.; Bachappanavar, N.; Kiran, S. Enhanced polymer degradation of polyethylene and polypropylene by novel thermophilic consortia of Brevibacillus sps. and Aneurinibacillus sp. screened from waste management landfills and sewage treatment plants. Polymer Degradation and Stability, v. 149, n. November 2017, p. 52-68, 2018.

[3] MEHMOOD, C. T.; Qazi, I. A.; Hashmi, I.; Bhargava, S.; Deepa, S. Biodegradation of low density polyethylene (LDPE) modified with dye sensitized titania and starch blend using Stenotrophomonas pavanii. Internernaional Biodeterioration and Biodegradation, v. 113, p. 276-286, 2016.

[4] HADAD, D.; Geresh, S.; Sivan, A. Biodegradation of polyethylene by the thermophilic bacterium Brevibacillus borstelensis. Journal of Applied Microbiology, v. 98, n. 5, p. 1093-1100, 2005. 
[5] RESTREPO-FLÓREZ, J.; Bassi, A.; Thompson, M. Microbial degradation anddeterioration of polyethylene - A review. International Biodeterioration and Biodegradation v. 88, p. 83-90, 2014.

[6] PEIXOTO, J.; Silva, L.; Krüger, R. Brazilian Cerrado soil reveals an untapped microbial potential for unpretreated polyethylene biodegradation. Journal of Hazardous Materials, v. 324, Parte B, p. 634-644, 2017.

[7] GEWERT, B.; Plassmann, M.; Macleod, M. Pathways for degradation of plastic polymers floating in the marine environment. Environ.Sci.: Proc. \& Imp., 17, 1513-1521, 2015.

[8] OJEDA, T.; Dalmolin, E.; Forte, M.; Jacques, R.; Bento, F.; Camargo, F. Abiotic and biotic degradation of oxobiodegradable polyethylenes. Polymer Degradation and Stability v. 94, p.965-970, 2009.

[9] AMMALA, A.; Bateman, S.; Dean, K.; Petinakis, E.; Sangwan, P.; Wong, S.; Yuan, Q.; Yu, L.; Patrick, C.; Leong, K. An overview of degradable and biodegradable polyolefins. Progress in Polymer Science v. 36, p. 1015-1049, 2011.

[10] NOWAK, B.; Pajak, J.; Drozd-Brarkowicz, M.; Rymarz, G. Microorganisms participating in the biodegradation of modified polyethylene films in different soils under laboratory conditions. International Biodeterioration and Biodegradation, v. 65, p. 757-767, 2011.

[11] SEN, S.; RAUT, S. Microbial degradation of low density polyethylene (LDPE): a Review. Journal Environmental Chemical Engineering, v. 3, 1, p. 462-473, 2015.

[12] COSTA, C.; Albuquerque, C.; Brum, M.; Castro, A. Degradação Microbiológica e Enzimática de Polímeros: Uma Revisão. Química Nova, v. 38, 2, p. 259-267, 2015.

[13] ESMAEILI, A., Pourbabaee, A. A., Alikhani, H. A., Shabani, F. And Esmaeili, E. Biodegradation of Low-Density Polyethylene (LDPE) by Mixed Culture of Lysinibacillus xylanilyticus and Aspergillus niger in Soil. PLoS ONE, v. 8, n. 9, 2013.

[14] JANCZAK, K.; Hrynkiewicz, K.; Znajewska, Z.; Dąbrowska, G. Use of rhizosphere microorganisms in the biodegradation of PLA and PET polymers in compost soil. International Biodeterioration \& Biodegradation v. 130, p. 65-75, 2018.

[15] ZHANG, X.-Z.; ZHANG, Y.-H. P. Cellulases: Characteristics, Sources, Production, and Applications. Bioprocess Technology in Bioreffinary for Sustaintable Production of Fuels, Chemicals and Polymers, p. 131-146, 2013.

[16] AHIRWAR, R., SHARMA, J. G., NAHAR, P. AND KUMAR, S. Immobilization studies of cellulase on three engineered polymer surfaces. Elsevier Ltd, 2017. v. 11

[17] MISHRA, A.; SARDAR, M. Cellulase assisted synthesis of nano-silver and gold: Application as immobilization matrix for biocatalysis. International Journal of Biological Macromolecules, v. 77, n. March, p. 105-113, 2015.

[18] PooraKBAR, E., Shafiee, A., Saboury, A. A., Rad, B. L., Khoshnevisan, K., Ma'mani, L., Derakhshankhah, H., Ganjali, M. R. And Hosseini, M. Synthesis of magnetic gold mesoporous silica nanoparticles core shell for cellulase enzyme immobilization: Improvement of enzymatic activity and thermal stability. Process Biochemistry, v. 71, n. December 2017, p. 92-100, 2018.

[19] CASTRO-AGUIRRE, E., Auras, R., Selke, S., Rubino, M. And Marsh, T. Insights on the aerobic biodegradation of polymers by analysis of evolved carbon dioxide in simulated composting conditions. Polymer Degradation and Stability, v. 137, p. 251-271, 2017. 


\section{Capítulo 19}

\section{Obtenção de liga de $\mathrm{NiCu}$ e Cu metálico com eletrodeposição pulsada variando corrente e pH}

\section{Thayane Carpanedo de Morais Nepel \\ Thales Antônio Amarante \\ Daniella Gonçalves Portela \\ Ambrósio Florêncio de Almeida Neto}

Resumo: A corrosão é responsável por perdas financeiras significativas, motivando o estudo e o desenvolvimento de novos materiais resistentes aos meios corrosivos, como as ligas metálicas de $\mathrm{NiCu}$. Nesse âmbito, este trabalho apresenta a influência da densidade de corrente elétrica, do pH e da concentração de íons de níquel no banho eletrolítico, na formação das ligas metálicas $\mathrm{NiCu}$, utilizando a eletrodeposição pulsada e um planejamento experimental fatorial completo $2^{3}$. Com pH 9 e densidade de corrente elétrica de $600 \mathrm{~mA}$ foi obtido um revestimento de $\mathrm{Ni}_{63} \mathrm{Cu}_{37}$, de composição semelhante à da resistente liga comercial Monel, homogêneo, aderente, com elevada cristalinidade e $81,05 \%$ de eficiência de deposição. Utilizando pH 2 e $200 \mathrm{~mA}$ foram produzidos depósitos de cobre metálico com 81,83\% de eficiência de deposição. Portanto, este trabalho concluiu que, a partir das variáveis estudadas, tanto a obtenção da liga $\mathrm{NiCu}$ como a eficiência de deposição podem ser alteradas. 


\section{INTRODUÇÃO}

A eletrodeposição consiste na passagem de corrente elétrica através de um banho eletrolítico condutor contendo íons metálicos, o que permite a redução desses íons com a deposição do metal na superfície do substrato, o qual se comporta como cátodo ${ }^{(1)}$. Esse processo possibilita ainda a utilização de efluentes com íons metálicos para a síntese de ligas, possibilitando a remoção desses íons e resultando no tratamento do efluente com a produção de um material com valor comercial( ${ }^{(2)}$.

Dentre as ligas metálicas que podem ser produzidas por eletrodeposição, as compostas por níquel e cobre destacam-se por suas propriedades magnéticas e térmicas, características de expansão, resistência à corrosão e aplicação decorativa ${ }^{(3,4)}$. 0 Monel-400 é um exemplo comercial de liga metálica de $\mathrm{NiCu}$, contendo de $30 \%$ a $40 \%$ de cobre em sua composição, conhecida pela sua elevada resistência à corrosão e sendo por isso utilizada em diversas aplicações, como em indústrias químicas na confecção de reatores, filtros, válvulas e tubulações ${ }^{(5)}$.

0 processo de eletrodeposição pode ser realizado por meio de diferentes técnicas eletroquímicas, incluindo corrente contínua e corrente pulsada. A corrente pulsada é aplicada em ciclos, onde cada ciclo é constituído de um intervalo curto de tempo no qual a corrente é aplicada $\left(\mathrm{t}_{o n}\right)$, seguido de um intervalo no qual não há aplicação de corrente $\left(\mathrm{t}_{o f f}\right)$. A utilização de corrente pulsada possibilita a reorganização dos cátions a serem depositados, garantindo assim melhores resultados na eletrodeposição.

0 uso da corrente pulsada é apontado na melhora de algumas propriedades dos materiais, como microdureza, aderência, homogeneidade, eficiência de deposição e resistência à corrosão(6-9). Ghosh e colaboradores (2000) mostram que a utilização de corrente pulsada permitiu obter uma liga de NiCu com melhor resistência à corrosão que o Monel, ao ser exposto a um meio contendo $\mathrm{NaCl} 3 \%(\mathrm{~m} / \mathrm{m})$ e elevadas temperaturas $(8)$.

Desta forma, o estudo de técnicas para obtenção de ligas metálicas com elevada qualidade mostra-se importante e necessário, inclusive para definição de parâmetros para a eletrodeposição utilizando resíduos industriais. Portanto, este trabalho objetivou estudar o processo de eletrodeposição, com corrente pulsada, para a síntese de ligas metálicas de $\mathrm{NiCu}$, variando a densidade de corrente elétrica utilizada, o pH e a concentração de íons níquel no banho eletrolítico, avaliando a influência destes parâmetros na composição das ligas formadas, suas características físicas e a eficiência de deposição do processo.

\section{MATERIAIS E MÉTODOS}

A técnica de eletrodeposição utilizada neste trabalho foi aplicada em um substrato de cobre no formato de uma placa quadrada com $2 \mathrm{~cm}$ de lado, tratado com polimento usando lixas de granulometria 400 e 1200 , seguido de tratamento químico sequencial em solução de hidróxido de sódio 10 \% e em ácido sulfúrico $1 \%(10)$.

O banho eletrolítico foi constituído por: sulfato de cobre e sulfato de níquel como sais, fonte de cobre e níquel; citrato de amônio como agente complexante; dodecilsulfato de sódio, a fim de evitar a formação de bolhas de hidrogênio no revestimento; e hidróxido de amônio ou ácido sulfúrico, para ajuste do $\mathrm{pH}$.

A concentração de sulfato de cobre foi fixada em $0,007 \mathrm{~mol} / \mathrm{L}$, sendo esta semelhante à do resíduo industrial procedente da indústria de bijuterias ${ }^{(11)}$. As variáveis $\mathrm{pH}$, concentração de sulfato de níquel e a corrente aplicada foram ajustadas de acordo com o planejamento experimental fatorial completo $2^{3}$, com três experimentos no ponto central, a fim de avaliar quantitativamente a influência dessas variáveis nos revestimentos formados. Os valores das variáveis de entrada estão dispostos na Tabela 1.

Tabela 1 - Valores das variáveis decodificadas.

\begin{tabular}{|c|c|c|c|}
\hline & \multicolumn{3}{|c|}{ Níveis } \\
\hline Variáveis & -1 & 0 & +1 \\
\hline $\mathrm{pH}$ & 2,0 & 5,5 & 9,0 \\
\hline CNi (mol/L) & 0,030 & 0,065 & 0,100 \\
\hline Corrente (mA) & 200 & 400 & 600 \\
\hline
\end{tabular}


Os experimentos de eletrodeposição foram realizados em uma célula eletroquímica de dois eletrodos, utilizando a técnica fast galvanic pulse, com pulsos de $1 \mathrm{~ms}$ aplicando corrente, seguidos de intervalos de 9 ms de circuito aberto.

Essa técnica foi aplicada por um potenciostato/galvanostato, sendo o contraeletrodo uma malha cilíndrica oca de platina. Acoplado ao substrato, utilizou-se ainda um eletrodo rotatório modelo 616A para controle da rotação catódica em 70 rpm, mantendo constantes as condições hidrodinâmicas do banho eletrolítico. 0 banho eletrolítico foi mantido a uma temperatura constante de $40^{\circ} \mathrm{C}$ através de um banho térmico, durante os 30 minutos de experimento.

A caracterização da composição e morfologia dos revestimentos obtidos, bem como a homogeneidade e presença de bolhas e/ou trincas no depósito foram realizadas por meio das técnicas de Microscopia Eletrônica de Varredura e Espectrometria de Energia Dispersiva de Raios X (EDX), conduzidas no equipamento LEO Electron Microscopy/Oxford 440i. A caracterização da cristalinidade dos revestimentos obtidos foi obtida por Difração de Raios X (DRX), com radiação $\mathrm{Cu} K \alpha$, comprimento de onda 1,52 , tamanho do passo 0,02 $2 \theta$ e tempo por passo de um segundo, realizada no equipamento Philips X'PERT.

A partir da composição determinada pelo EDX obteve-se a fração mássica de cada metal constituinte dos recobrimentos, sendo possível calcular a eficiência de deposição $\varepsilon$ (Equação 1).

$$
\varepsilon=\frac{m \cdot F}{i \cdot t} \cdot \sum_{m} \frac{n_{m} \cdot w_{m}}{M_{m}} \cdot 100
$$

sendo: $\varepsilon(\%)$, a eficiência de deposição; $\mathrm{m}(\mathrm{g})$ a massa do revestimento metálico; i (A) a corrente elétrica total aplicada no eletrodo de trabalho; $\mathrm{w}_{\mathrm{m}}$ a fração mássica do metal no revestimento, determinada por EDX; $\mathrm{n}_{\mathrm{m}}$ é o número de elétrons transferidos por cada átomo metálico $(\mathrm{m})$, considerando a redução completa do Ni (II) e Cu (II); $\mathrm{M}_{\mathrm{m}}$ (g/mol) a massa atômica de cada metal $\mathrm{m}$ e $\mathrm{F}$ a constante de Faraday igual a $96.485 \mathrm{C} / \mathrm{mol}$. A incógnita t é o tempo de aplicação de corrente e, considerando que a corrente é pulsada, sendo aplicada apenas por um segundo a cada 10 segundos de operação, tem-se 180 segundos de corrente aplicada durante todo o processo de eletrodeposição.

\section{RESULTADOS E DISCUSSÃO}

\subsection{ESTUDO DA INFLUÊNCIA DAS VARIÁVEIS NA EFICIÊNCIA DE DEPOSIÇÃO E COMPOSIÇÃO DOS REVESTIMENTOS METÁLICOS}

A porcentagem de níquel e de cobre nos recobrimentos metálicos obtidos por eletrodeposição foi determinada através da análise de Energia Dispersiva de Raios X (EDX). Com estas porcentagens, e utilizando a Equação 1, foram calculadas as eficiências de deposição dos experimentos. A Tabela 2 apresenta os resultados de eficiência de deposição, assim como a fração mássica de níquel e cobre para cada recobrimento obtido.

Tabela 2 - Planejamento fatorial $2^{3}$ em função da composição e da eficiência da deposição

\begin{tabular}{|c|c|c|c|c|c|c|}
\hline $\operatorname{Exp}$ & $\mathrm{CNi}$ & $\mathrm{pH}$ & Corrente & $\begin{array}{l}\text { Fração mássica Ni } \\
(\%)\end{array}$ & $\begin{array}{l}\text { Fração mássica } \mathrm{Cu} \\
(\%)\end{array}$ & Eficiência (\%) \\
\hline 1 & -1 & -1 & -1 & 0,00 & 100,00 & 81,83 \\
\hline 2 & +1 & -1 & -1 & 0,00 & 100,00 & 78,46 \\
\hline 3 & -1 & +1 & -1 & 0,38 & 99,62 & $-3,38$ \\
\hline 4 & +1 & +1 & -1 & 5,33 & 94,67 & 14,41 \\
\hline 5 & -1 & -1 & +1 & 0,73 & 99,27 & 21,67 \\
\hline 6 & +1 & -1 & +1 & 1,71 & 98,29 & 25,06 \\
\hline 7 & -1 & +1 & +1 & 62,67 & 37,33 & 57,38 \\
\hline 8 & +1 & +1 & +1 & 62,52 & 37,48 & 81,04 \\
\hline $9(\mathrm{C})$ & 0 & 0 & 0 & 0,67 & 99,33 & 37,57 \\
\hline $10(\mathrm{C})$ & 0 & 0 & 0 & 0,67 & 99,33 & 36,72 \\
\hline $11(\mathrm{C})$ & 0 & 0 & 0 & 0,67 & 99,33 & 38,41 \\
\hline
\end{tabular}


Analisando os resultados apresentados na Tabela 2, verifica-se que os maiores valores de eficiência de deposição foram obtidos para os experimentos 1 e 8 quando foram utilizados, respectivamente, os menores e maiores níveis das variáveis estudadas (concentração de níquel, corrente e pH). Entretanto, mantendo as variáveis no menor nível o depósito obtido é puramente de cobre metálico; enquanto no maior nível existe uma distribuição de cobre e níquel na liga com concentrações próximas a 37\% de cobre e 63\% de níquel, proporção esta característica das ligas comerciais Monel, a qual apresenta boas propriedades mecânicas e de resistência à corrosão(5).

Entre os experimentos 7 e 8, que foram conduzidos com máximos valores de corrente e pH, mas variando a concentração de níquel, obteve-se semelhante composição e nota-se que a diminuição na concentração de Níquel reduziu a eficiência de deposição em 23,66 \%. Relação inversa pode ser observada comparando os experimentos 1 e 2, uma vez que a diminuição da concentração de níquel no banho eletrolítico favorece a eletrodeposição do cobre metálico, aumentando assim a eficiência de deposição.

Os valores máximos de eficiência obtidos são comparáveis, quando não superiores, aos relatados na literatura para ligas $\mathrm{NiCu}$ com semelhante composição(6,8,12). A relação da eficiência com as variáveis estudadas, gerada no software Statística 10, é ilustrada na superfície de resposta apresentada na Figura 1. A superfície de resposta foi gerada mantendo a concentração de níquel 0,10 mol/L e mostrou que a eficiência tende a aumentar conforme os valores de pH e corrente, em conjunto, aumentam ou diminuem.

Figura 1 - Superfície de resposta ilustrando a influência das variáveis pH e corrente elétrica na Eficiência de deposição.

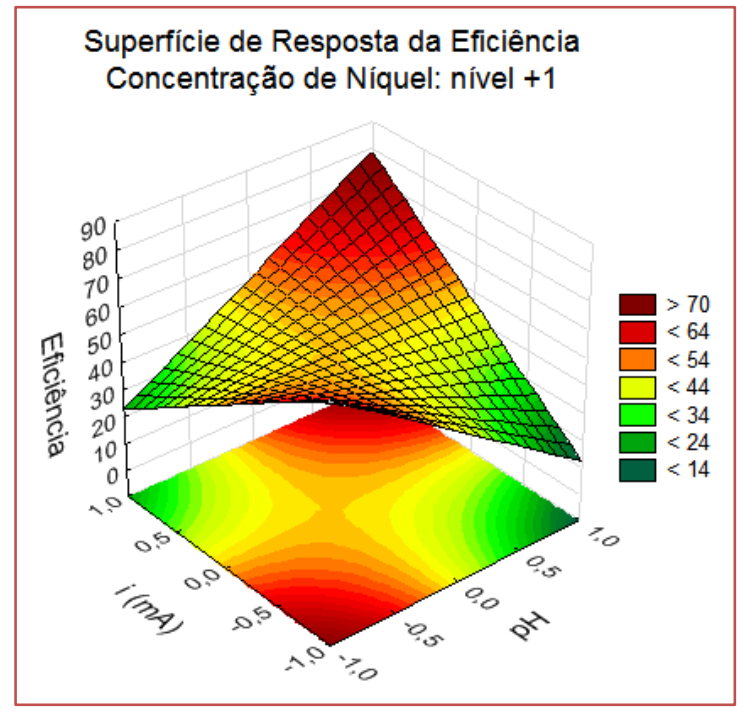

Os resultados apresentados na Tabela 2 foram analisados através do software Statistica 10 com $95 \%$ de confiança e erro puro, indicando que todas as variáveis estudadas influenciam significativamente a resposta de eficiência de deposição. A Figura 2 apresenta o gráfico de Pareto, ilustrando esta influência das variáveis e ressaltando a sinergia entre elas.

A análise pelo gráfico de Pareto aponta ainda que o fator que mais influência na eficiência de eletrodeposição é a sinergia entre as variáveis pH e a corrente. Essa sinergia foi também responsável pela composição do revestimento obtido, conforme pode ser observado na Tabela 2. 
Figura 2 - Gráfico de Pareto analisando a Eficiência de deposição como resposta em função das variáveis concentração de níquel, pH e corrente

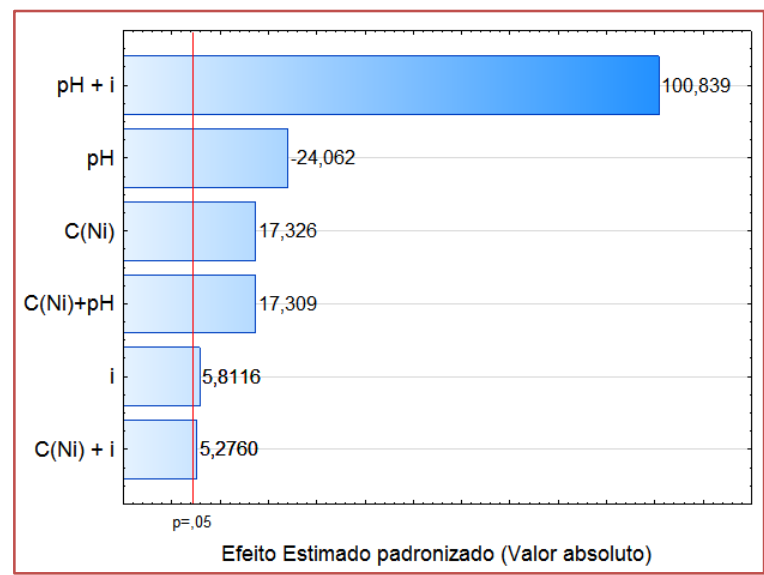

Outros autores $(9,13)$, utilizando banho de citrato, semelhante técnica e substrato que foram utilizadas no presente trabalho, apontaram que o aumento da corrente eleva a proporção de níquel na liga pelo fato de a eletrodeposição do cobre ser controlada pela transferência de massa, enquanto que a do níquel é controlada pela transferência de carga. Todavia, estes últimos não avaliaram a influência do pH e da concentração do banho eletrolítico.

Alper e colaboradores ${ }^{3}$ variaram o $\mathrm{pH}$ de 2,0 a 3,3, utilizando como substrato titânio e como técnica de eletrodeposição aplicação de potencial. Apontaram que o aumento do potencial hidrogeniônico diminuía a concentração de níquel na liga, o oposto do que indica os resultados acima apesentados, denotando a importância dos complexos formados de acordo com a composição, pH do banho eletrolítico, assim como a técnica pulsada. Portanto, o presente trabalho apresenta novas informações relevantes não somente sobre as variáveis analisadas, como também sobre a sinergia entre elas, e ressalta a importância de todos parâmetros envolvidos na eletrodeposição, incluindo a técnica eletroquímica utilizada.

\subsection{CARACTERIZAÇÃO DOS REVESTIMENTOS METÁLICOS}

A análise de MEV - EDS, além da composição dos revestimentos obtidos, forneceu informações sobre a morfologia dos mesmos. A liga obtida no experimento 8, que apresentou composição próxima ao Monel, maior eficiência de deposição e elevada aderência, também apresentou uma superfície uniforme, sem trincas, com apenas alguns pequenos pontos de depressão, conforme mostrado na Figura 3a.

Figura 3 - Micrografias de MEV dos revestimentos metálicos obtidas com ampliação de 5000x relativas aos experimentos 8, 7, 1 e 3 .
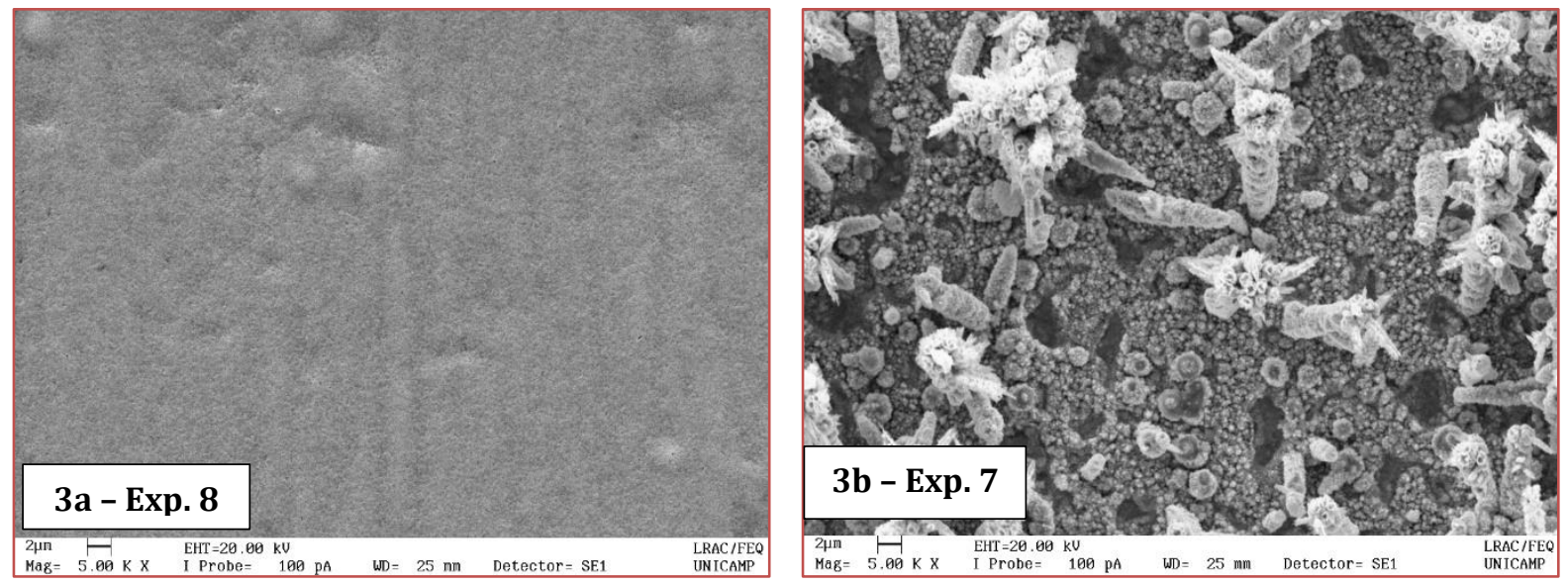
Figura 3 - Micrografias de MEV dos revestimentos metálicos obtidas com ampliação de 5000x relativas aos experimentos 8, 7, 1 e 3. (Continuação)
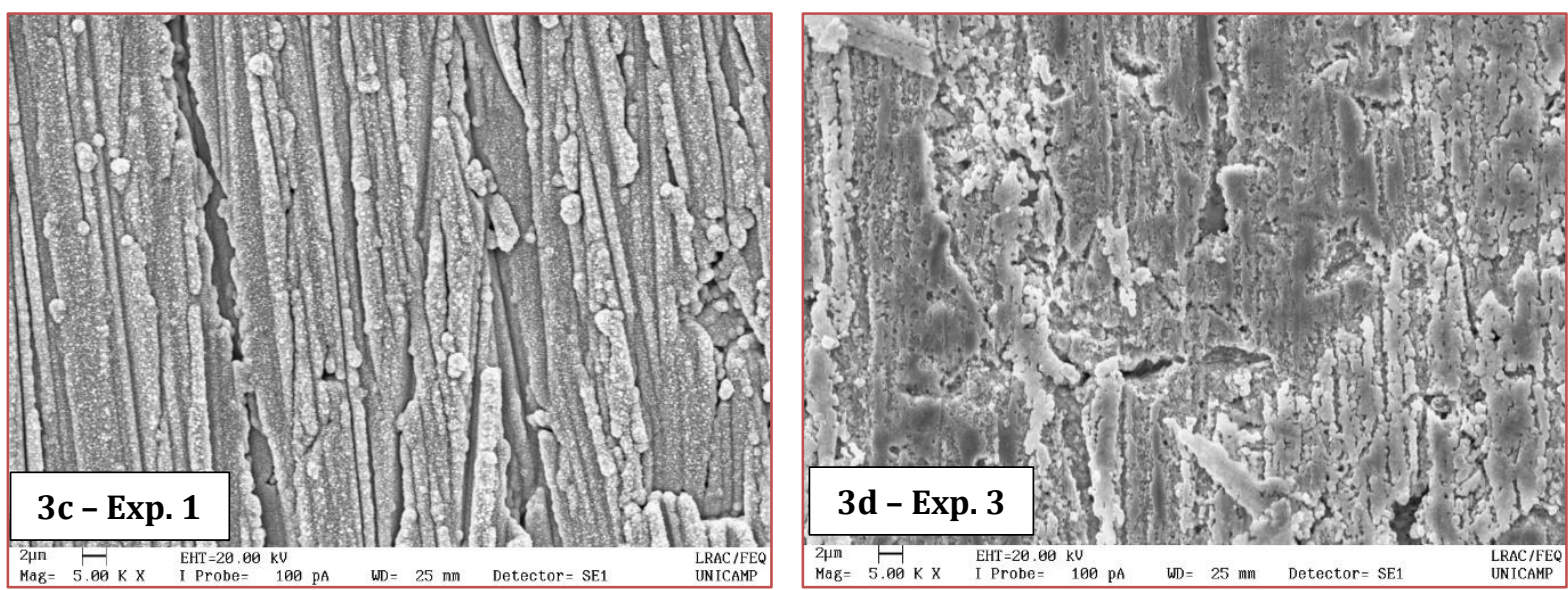

A liga obtida no experimento 7, que também teve composição semelhante ao Monel, mas menor eficiência de deposição, apresentou morfologia diferenciada com formações cristalinas pontiagudas. Semelhante às formações dendríticas, estas estruturas podem ter sido obtidas pela rápida transferência dos elétrons no cátodo substrato comparado à difusão dos cátions de níquel que se encontram em menor concentração no banho eletrolítico 7. Isso porque as formações dendríticas são preferidas quando a transferência de massa é favorecida pela deposição de átomos nas extremidades das formações cristalinas ${ }^{(1)}$.

Além disso, as formações dendríticas podem apresentar baixa aderência, como foi observado neste trabalho, visto que a liga 7 apresentou uma espécie de pó cinza pouco aderente sobre o recobrimento metálico.

A micrografia do recobrimento de cobre metálico obtido no experimento 1 é apresentada na Figura 3c onde observa-se homogeneidade e pequenas depressões devido ao processo de lixamento do substrato. A figura 3d, que apresenta a micrografia do experimento 3, indica não só as ranhuras do processo de lixamento, mas também a corrosão(14) ${ }^{(1)}$ iginada pela baixa concentração de níquel, associada à baixa corrente e ao alto valor de pH. Essa corrosão foi confirmada pelo valor negativo da eficiência de deposição, apresentada na Tabela 2, e é explicada pelo fato da associação dos parâmetros nesse experimento terem dificultado a eletrodeposição contribuindo para a corrosão do substrato e resultando em perda de massa do mesmo.

A Figura 4 apresenta os difratogramas de raio-x dos recobrimentos metálicos obtidos nos experimentos 1 e 8. 0 difratograma do cobre metálico apresenta os picos típicos para o cobre em $2 \theta=43.3^{\circ}$ e $50.5^{\circ}(15)$.

Conforme apontado por outros autores, quando ocorre a formação da liga $\mathrm{NiCu}$ os picos característicos do cobre são deslocados para valores superiores de $2 \theta$, sendo observado os picos relativos à liga $\mathrm{NiCu}$ em $2 \theta$ $\approx 44^{\circ}, 51^{\circ}, 76^{\circ}, 90^{\circ}$, os quais podem ser indexados como os planos (111), (200), (220) e (311) (15,1615). Os difratogramas indicam ainda a elevada cristalinidade dos recobrimentos metálicos obtidos, independentemente da composição dos mesmos.

Figura 4 - Difratogramas de NiCu obtidos nos experimentos 1 e 8.

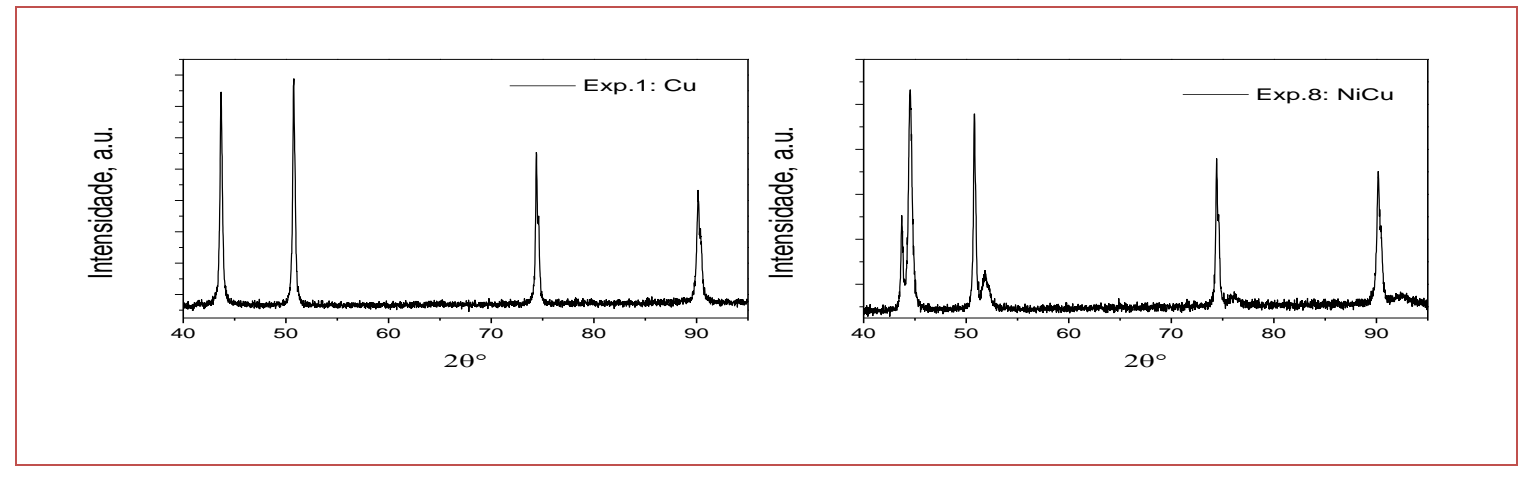




\section{CONCLUSÃO}

Os resultados apontam que no maior nível das variáveis estudadas (concentração de níquel no banho eletrolítico igual à $0,100 \mathrm{~mol} / \mathrm{L}$, em pH 9 e corrente de $600 \mathrm{~mA}$ ) obtém-se a maior eficiência de deposição $(81,05 \%)$. Utilizando estes parâmetros foi obtida a liga $\mathrm{Ni}_{63} \mathrm{Cu}_{37}$, aderente, cristalina, homogênea e isenta de trincas ou descontinuidades, com composição semelhante às ligas comerciais Monel, as quais são conhecidas por sua resistência à corrosão e ampla aplicabilidade.

Já empregando as variáveis no menor nível (concentração de níquel no banho eletrolítico de 0,030, pH 2 e 200mA de corrente) obteve-se um depósito de cobre metálico com 81,83\% de eficiência de deposição.

Portanto, o presente estudo apontou a influência das variáveis estudadas nas respostas de eficiência de deposição e composição dos revestimentos metálicos obtidos, permitindo assim a definição de parâmetros para a eletrodeposição de ligas de $\mathrm{NiCu}$.

\section{AGRADECIMENTOS}

Os autores agradecem ao CNPq e à FAPESP pelo apoio financeiro.

\section{REFERÊNCIAS}

[1] Pletcher, D.; Walsh F.C. Industrial Electrochemistry. 2a ed. (Professional CBA\&, ed.). London: Chapman \& Hall, 1990.

[2] Santos, I.C.; de A. Monteiro, L.P.C.; Mainier F.B. Tratamento de efluentes aquosos contendo cádmio, chumbo e cobre, a partir da técnica de eletrodeposição. Rev Augustus., v.20, n.40, p.143-154, 2015.

[3] Alper, M.; Kockar, H.; Safak, M.; Baykul, MC. Comparison of Ni-Cu alloy films electrodeposited at low and high pH levels. J Alloys Compd., v.453, n.1, p.15-19, 2008.

[4] Romankov, S.; Park, Y.C.; Komarov, S. V. Formation of composite CuWNi layers on ceramic substrates under shot impact treatment. J Alloys Compd., v.689, p.777-786, 2016.

[5] Singh, V.B.; Gupta, A. The electrochemical corrosion and passivation behaviour of Monel (400) in concentrated acids and their mixtures. J Mater Sci., v.36, n.6, p.1433-1442, 2001.

[6] Cherkaoui, M.; Chassaing, E.; Vu Quang, K. Pulse plating of Ni-Cu alloys. Surf Coatings Technol., v. 34, n.3, p.243-252, 1988.

[7] Donten, MX.; Cesiulis, H.; Stojek, Z. Electrodeposition and properties of Ni-W, Fe-W and Fe-Ni-W amorphous alloys. A comparative study. Electrochim Acta., v.45, n.20, p.3389-3396, 2000.

[8] Ghosh, S.K.; Grover, A.K.; Dey G.K.; Totlani, M.K. Nanocrystalline Ni-Cu alloy plating by pulse electrolysis. Surf Coatings Technol., v.126, n.1, p.48-63, 2000.

[9] Baskaran, I.; Sankara Narayanan T.S.N.; Stephen, A. Pulsed electrodeposition of nanocrystalline Cu-Ni alloy films and evaluation of their characteristic properties. Mater Lett., v.60, n.16, p.1990-1995, 2006.

[10] Baldessin C.F.; Nepel, T.C.D.M.; de Almeida Neto A.F. The influence of Ni and Co concentration in the electroplating bath on Ni-Co-W alloys properties. Can J Chem Eng., v.9999, p.1-6, 2017.

[11] Nepel, T.C.D.M.; Vieira, M.G.A.; Neto, A.F.D.A. Copper removal kinetics from real electroplating wastewater using pulsed electrodeposition. In:IMCRRE 2018, Mazatlan, México, 2018. Anais:p.13-14.

[12] Silaimani, S.M.; Vivekanandan, G.; Veeramani, P. Nano-nickel-copper alloy deposit for improved corrosion resistance in marine environment. Int J Environ Sci Technol., v.12, n.7, p.2299-2306, 2015.

[13] Srinivas, P.; Hamann, S.; Wambach, M.; Kieschnick, M.; Ludwig, A.; Dey SR. Development of Ni-Cu materials library by using combinatorial pulsed electrodeposition. Trans Indian Inst Met., v. 66, n.4, p.429-432,2013.

[14] Fazal, M.A.; Suhaila, N.R.; Haseeb, ASMA.; Rubaiee, S.; Al-Zahrani A. Influence of copper on the instability and corrosiveness of palm biodiesel and its blends: An assessment on biodiesel sustainability. J Clean Prod., v.171, p.1407$1414,2018$.

[15] Pellicer, E.; Varea, A.; Pané S.; et, al.; A comparison between fine-grained and nanocrystalline electrodeposited $\mathrm{Cu}$-Ni films. Insights on mechanical and corrosion performance. Surf Coatings Technol., v.205, v.2324, p.5285-5293, 2011.

[16] Nath, P.; Kumar, D.; Mallik, A. Surface \& Coatings Technology Physicochemical and corrosion properties of sono-electrodeposited $\mathrm{Cu}-\mathrm{Ni}$ thin fi lms., v.307, p.772-780, 2016. 


\section{Capítulo 20}

Caracterização mecânica e térmica de blendas de PP Virgem/PP Reciclado com destino à fabricação de para-choques

Wallisson Alves da Silva

Carlos Bruno Barreto Luna

João Baptista da Costa Agra de Melo

Edcleide Maria Araújo

Resumo: Estudos têm sido realizados com o intuito de reaproveitar os polímeros commodities, visando à minimizar os efeitos negativos no meio ambiente, assim como valorizando um material que seria descartado. Neste trabalho, analisaram-se as propriedades mecânicas e térmicas de blendas de PP virgem/PP reciclado, contendo 20, 40, e $60 \%$ de material reciclado, com o intuito da aplicação do material na indústria automobilística, produzindo para-choques. As blendas foram inicialmente preparadas em uma extrusora de rosca dupla e, posteriormente, os grânulos extrudados foram moldados por injeção. Verificou-se que as propriedades de tração e flexão (módulo elástico e resistência) aumentaram em relação à resina virgem, sendo atribuídas ao aumento do grau de cristalinidade, conforme verificado na análise de calorimetria exploratória diferencial (DSC). Por outro lado, o alongamento na ruptura e a resistência ao impacto reduziram, indicando um aumento na fragilidade à medida que aumenta o teor de PP reciclado. No geral, as blendas contendo 20 e $40 \%$ de PP reciclado apresentam conformidade com as normas exigidas para para-choques.

Palavras-chave: Reaproveitamento, para-choques, polipropileno, blendas poliméricas, propriedades mecânicas. 


\section{INTRODUÇÃO}

A vida contemporânea tem causado um aumento considerável na geração de resíduos sólidos, principalmente em decorrência do consumo de produtos industrializados, que necessitam de embalagens de plásticos. Geralmente, grande parte destes materiais permanecem por centenas e milhares de anos no ambiente, causando não só uma agressão aos ecossistemas, como também um problema econômico e social [1].

Os resíduos poliméricos pós-consumo e pós-industriais são fontes de poluição que causam inúmeros problemas, representando um desafio para o gerenciamento do lixo em grandes cidades. Com o consumo crescente de polímeros em diversos setores da indústria, estes problemas tendem a ser agravados se não forem adotadas políticas eficientes de reaproveitamento destes materiais [2]. 0 reaproveitamento de plásticos é uma prática consolidada e constitui-se uma alternativa para a redução da demanda por matérias-primas petroquímicas, contribuindo assim, para minimizar os impactos ambientais e favorecer o desenvolvimento sustentável [3].

Os tipos de polímeros mais consumidos (considerados commodities) são os polietilenos (PE), polipropilenos (PP), policloreto de vinila (PVC), poliestirenos (PS), polietileno tereftalato (PET) e poliuretanos (PU) [4]. Atualmente, a questão do reaproveitamento dos polímeros commodities é uma das principais preocupações para a comunidade científica e da indústria, bem como dos ambientalistas [5]. Uma das alternativas utilizadas para o reaproveitamento dos polímeros é por meio do desenvolvimento de blendas poliméricas, ou seja, a mistura física de dois ou mais polímeros [6]. Por uma outra perspectiva, a indústria automobilística vem progressivamente substituindo componentes metálicos por peças plásticas, visto que acarreta num melhor desempenho no que tange a absorção de impacto e maior segurança para os ocupantes do veículo. Embasado nesses aspectos, fica evidente a necessidade crescente da reciclagem de materiais plásticos, e dentre as peças automotivas, o para-choques, devido ao seu tamanho e composição química será o objeto de destinação da pesquisa.

Os para-choques são feitos majoritariamente de um único material, o polipropileno (PP), que é um polímero termoplástico, possibilitando o processo de reciclagem. No entanto, ao ser reciclado suas características mecânicas são alteradas, tornando-se mais frágeis a esforços mecânicos [7].

Portanto, foi tomado como objetivo, analisar a influência da concentração de polipropileno reciclado (PPR) em misturas com polipropileno copolímero virgem (PPV), objetivando determinar até que ponto poderíamos utilizar PP reciclado na fabricação de para-choques de forma a preservar as características mecânicas exigidas em norma.

\section{REVISÃO BIBLIOGRÁFICA}

\subsection{POLÍMEROS: POLIPROPILENO}

O polipropileno ou PP, cuja fórmula molecular é (C3H6)n, é um termoplástico semicristalino produzido a partir da polimerização do gás propeno, sendo o petróleo a principal fonte para produção desse polímero atualmente.

Algumas de suas principais características são: baixo custo, alta resistência química a solventes, atóxico, fácil moldagem, fácil de realizar pigmentação, alta resistência à fratura por flexão ou fadiga, moderada resistência ao impacto, elevada rigidez e boa estabilidade térmica.

Figura 1 - Fórmula estrutural do monômero.

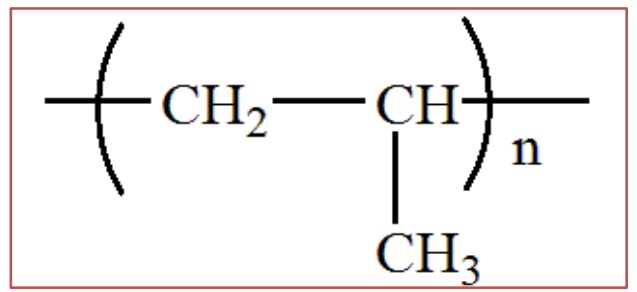

Fonte: Imagem da Internet. 
Há uma vasta gama de produtos onde o material é empregado no dia a dia, tais como cadeiras plásticas, brinquedos, baldes, seringas de injeção, tampas de refrigerantes, embalagens, eletrodomésticos, autopeças, entre outros.

O tempo médio de decomposição na natureza do PP chega a ser alguns séculos (um copo descartável confeccionado com PP, por exemplo, leva entre 250 e 400 anos para biodegradar-se completamente), mostrando assim a importância da utilização desse material de forma consciente.

O polipropileno pode ser reciclado com certa facilidade, dessa forma para facilitar a identificação desse material, todo plástico produzido a partir da polimerização do gás propeno tem um selo ou marca de identificação em seus produtos, que pode ser reconhecida facilmente pelo símbolo triangular (que se refere a produtos recicláveis), com o número cinco dentro e com a nomenclatura "PP" escrita nele.

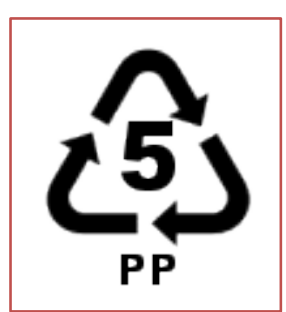

\subsection{POLÍMEROS: CRISTALINIDADE}

A cristalinidade em polímeros é uma medida do grau de organização em que os esferulitos do polímero encontram-se. Quanto mais organizada a estrutura for, mais cristalino é o polímero. Quando não há qualquer ordem nas cadeias poliméricas, ou seja, estão elas completamente emaranhadas, dizemos que trata-se de um polímero amorfo.

Na prática a maioria dos polímeros são semicristalinos, isto é, parte da sua microestrutura é formada por regiões bem ordenadas e parte é formada por regiões completamente desordenada.

Figura 2 - Representação das cadeias poliméricas de um polímero semicristalino, no qual há regiões cristalinas e regiões amorfas.

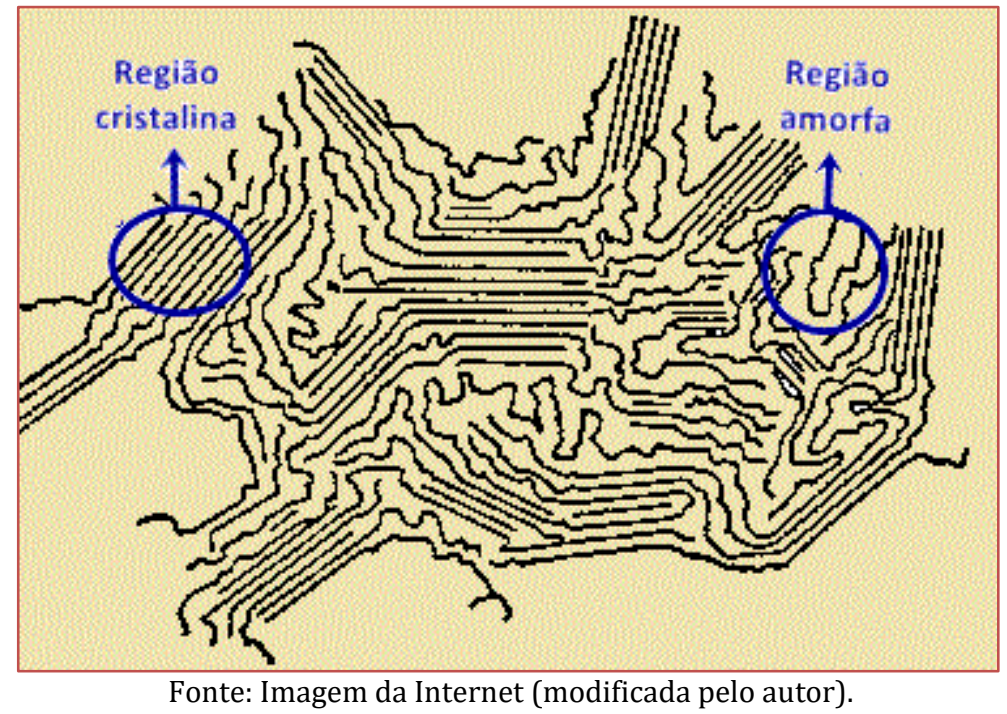

As propriedades mudam muito de acordo com o quão cristalino um polímero é. Regiões amorfas impedem as cadeias de se aproximarem e organizarem, consequentemente, há um espaço muito grande entre cada cadeia e a densidade do polímero diminui. 0 contrário ocorre em regiões cristalinas, as cadeias ficam bem próximas umas das outras tornando assim o material mais denso e rígido, por consequência, sofre perdas em sua capacidade plástica. 


\subsection{PROCESSO DE EXTRUSÃO}

O processo de conformação mecânica denominado extrusão é utilizado para a transformação de termoplásticos que consiste em empurrar o material (normalmente em seu estado fundido) através de uma matriz de extrusão, gerando a forma planejada. Os materiais plásticos são misturados conforme o produto final a ser fabricado, e colocados na Extrusora que irá empurrá-los até a matriz de extrusão.

A Extrusora é uma máquina que, como princípio geral, possuí uma entrada de material chamada de funil de alimentação, vindo em seguida um corpo formado por um cilindro, dentro do qual gira um parafuso sem fim (rosca) e uma cabeça que serve de suporte para a matriz de extrusão.

Figura 3 - Equipamentos presentes na máquina Extrusora de plástico.

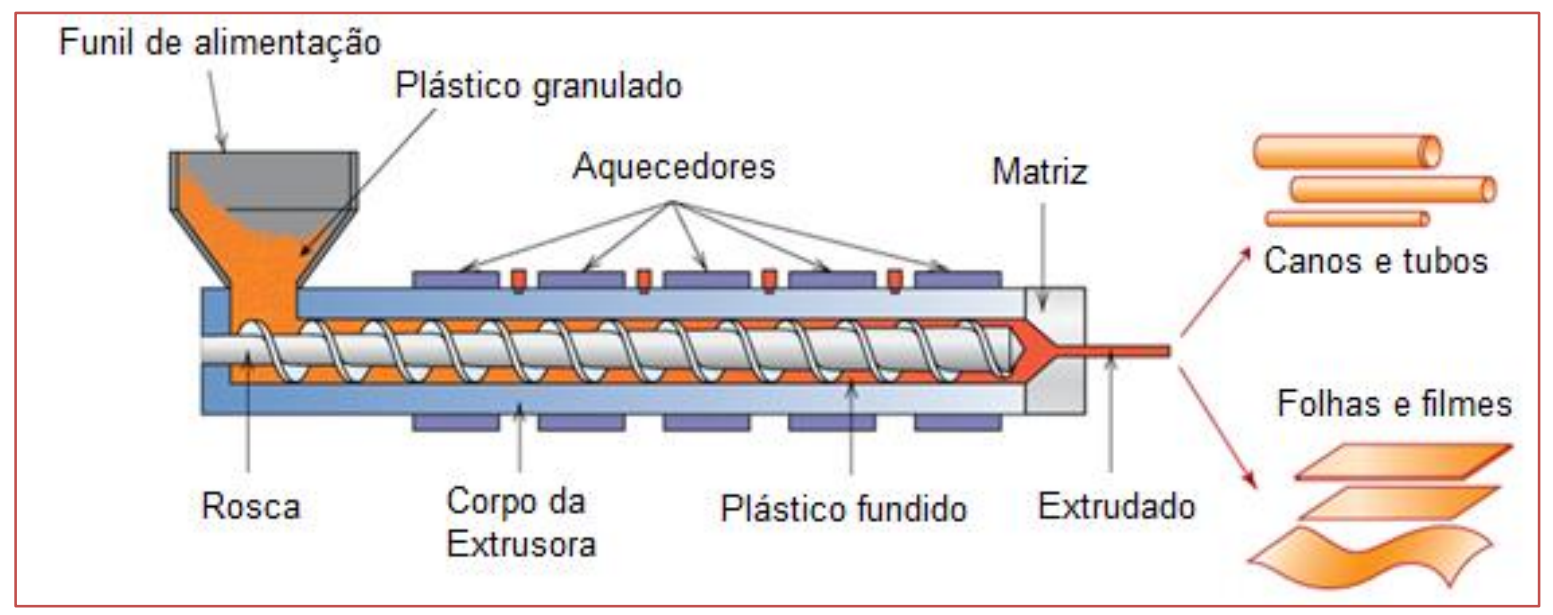

Fonte: Imagem da Internet (modificada pelo autor).

Os filmes de polipropileno extrudados podem ser empregados diretamente para embalagens em geral. Ademais, é muito comum utilizar a máquina de extrusão quando se quer confeccionar blendas poliméricas, visto que a rotação da rosca atrelado à elevada temperatura no interior do corpo da máquina, favorecem a homogeneização dos dois ou mais fundidos.

\subsection{ENSAIO DE TRAÇÃO}

No ensaio de tração, uma carga de tração uniaxial crescente é aplicada em um corpo de prova específicado até a ruptura. Mede-se a variação no comprimento como função da carga aplicada, e após o tratamento adequado dos resultados, obtêm-se uma curva tensão-deformação do corpo de prova.

O ensaio de tração é bastante utilizado como teste para o controle das especificações da entrada de matéria-prima e controle de processo. Os resultados fornecidos pelo ensaio são fortemente influenciados pela temperatura, velocidade de deformação, anisotropia do material, tamanho do grão, porcentagem de impurezas, bem como pelas condições ambientais [8].

A figura a seguir mostra uma representação esquemática da máquina utilizada nesse ensaio. 
Figura 4 - Esboço de uma máquina para ensaio de tração/flexão (três pontos).

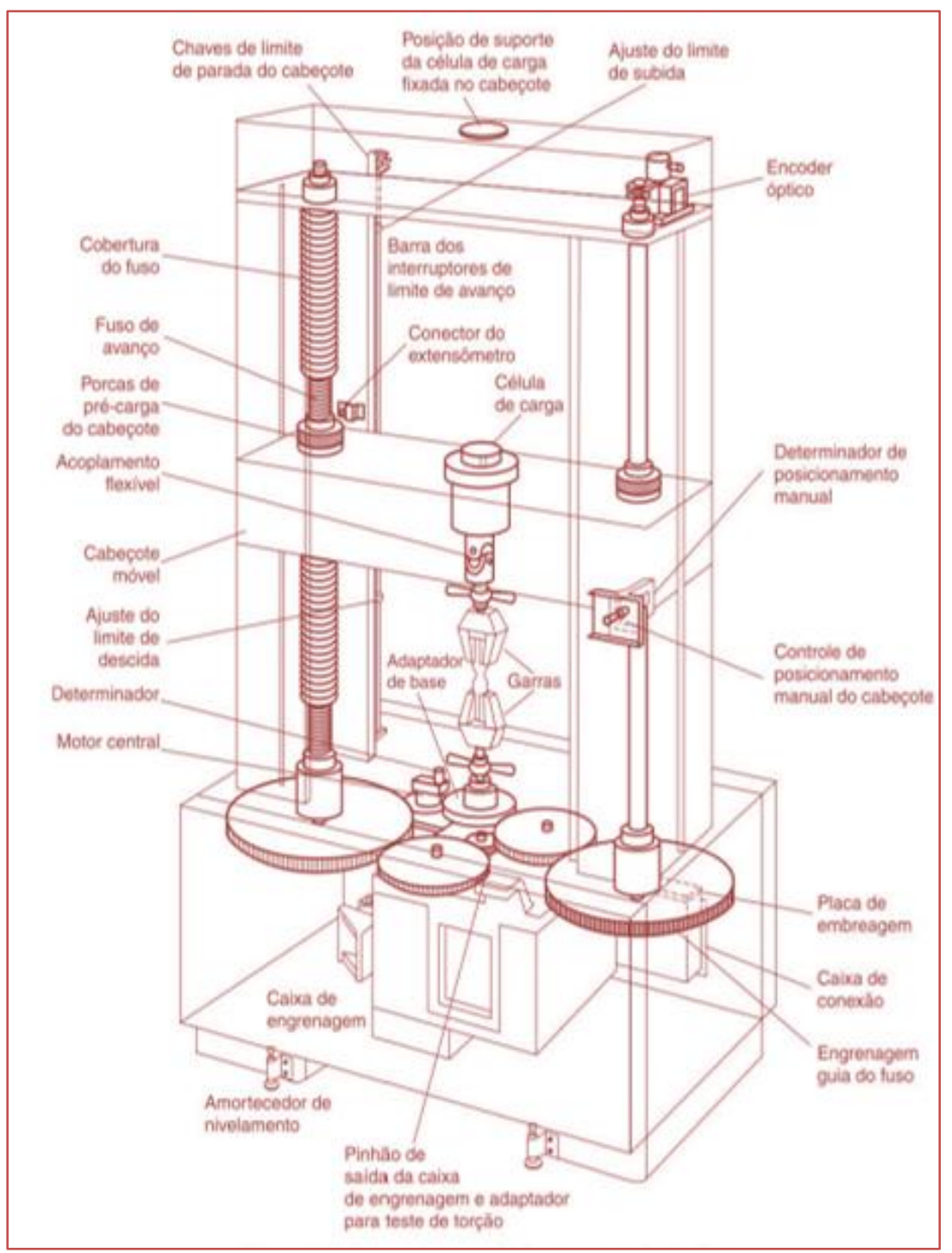

Fonte: Ensaios dos Materiais. Amauri Garcia - 2ª edição [8].

\subsection{ENSAIO DE FLEXÃO}

No ensaio de flexão, uma carga crescente é aplicada em determinados pontos de uma barra de geometria padronizada, a qual pode estar na condição biapoiada ou engastada em uma das extremidades. Mede-se o valor da carga versus a deformação máxima, ou a flecha, atingida na flexão. Existem três tipos principais desse ensaio: o ensaio de flexão em três pontos, em que a barra a ser testada é biapoiada nas extremidades e a carga é aplicada no centro do comprimento do corpo de prova; o ensaio de flexão em quatro pontos, em que a barra a ser testada é biapoiada nas extremidades e a carga é aplicada em dois pontos na região central do comprimento, separados por uma distância padronizada; e o chamado método engastado, que consiste em engastar uma extremidade do corpo de prova e há aplicação da carga na outra extremidade.

É um ensaio bastante empregado para o controle das especificações mecânicas de componentes. Os resultados fornecidos pelo ensaio de flexão podem variar com a temperatura, a velocidade de aplicação da carga, defeitos superficiais e características microscópicas e, principalmente, com a geometria da seção transversal da amostra [8].

A máquina utilizada no ensaio de tração também pode ser utilizada para o ensaio de flexão em três pontos (assim como também para outros tipos de esforços), bastando modificar as garras do equipamento para garras apropriadas à flexão. 


\subsection{ENSAIO DE IMPACTO}

No ensaio de impacto, uma carga é aplicada na forma de esforços por choques dinâmicos, e o impacto é obtido por meio da queda de um martelo ou pendulo, de uma altura determinada, sobre a peça a examinar.

As massas utilizadas nos ensaios são intercambiáveis, possuem diferentes pesos e podem cair de alturas variáveis. Os ensaios mais conhecidos são denominados Charpy e Izod, a depender da configuração geométrica do entalhe e do modo de fixação do corpo de prova na máquina [8].

Figura 5 - Esboço de uma máquina para Ensaio de Impacto (Charpy/Izod).

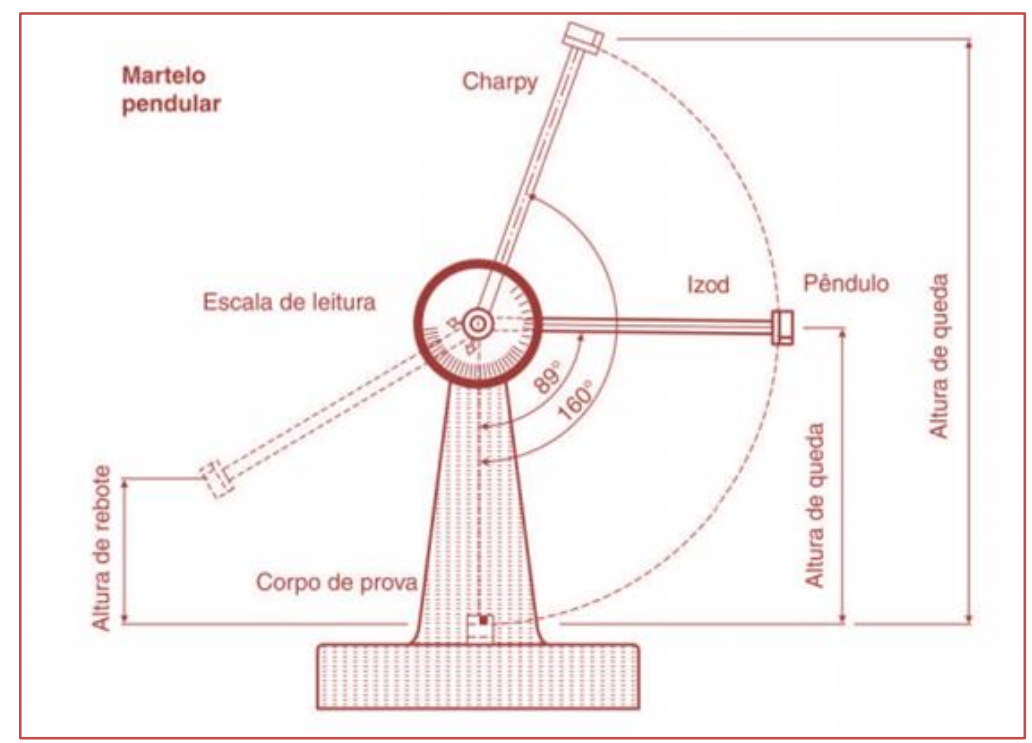

Fonte: Ensaios dos Materiais. Amauri Garcia - 2ª edição [8].

Como resultado do ensaio, obtém-se a energia absorvida pelo material até a fratura, ou seja, a tenacidade ao impacto, além da resistência ao impacto relacionando-se a energia absorvida com a área da seção resistente. Além disso, o comportamento dúctil-frágil dos materiais pode ser amplamente caracterizado pelo ensaio de impacto.

Esse tipo de ensaio é amplamente utilizado nas indústrias naval e bélica, e, em particular, nas construções que deverão suportar baixas temperaturas.

\section{MATERIAIS E MÉTODOS}

\subsection{MATERIAIS}

As blendas foram preparadas a partir do polipropileno copolímero heterofásico (PPV), comercializado com o código EP440P, na forma de grânulos, densidade de 0,895 g/cm3 e com índice de fluidez de 6 $\mathrm{g} / 10 \mathrm{~min}$, adquirido da Braskem. Foi utilizado como material reciclado o polipropileno (PPr) proveniente de baldes industriais cuja função original é o armazenamento de margarina.

\subsection{PREPARAÇÃO DO POLIPROPILENO RECICLADO}

Inicialmente, os baldes de polipropileno reciclado foram submetidos ao processo de separação, onde os rótulos de adesivos foram removidos. Os baldes foram triturados em um moinho de facas dando origem aos flocos. Posteriormente, os fragmentos dos baldes passaram por um processo de secagem em uma estufa com vácuo por $24 \mathrm{~h}$ em temperatura de $60^{\circ} \mathrm{C}$. 


\subsection{PREPARAÇÃO DAS BLENDAS}

As blendas foram misturadas a seco e, posteriormente, processadas em uma extrusora de rosca dupla corrotacional modular, modelo ZSK ( $D=18 \mathrm{~mm}$ e L/D = 40), da Coperion Werner-Pfleiderer, com temperatura de $185^{\circ} \mathrm{C}$ em todas as zonas, velocidade de rotação da rosca de $250 \mathrm{rpm}$ e taxa de alimentação controlada de $4 \mathrm{~kg} / \mathrm{h}$, com perfil de rosca configurado com elementos de misturas distributivos e dispersivos. Após o processamento dos materiais por extrusão, os mesmos foram granulados e secos em uma estufa com vácuo por $24 \mathrm{~h}$ em temperatura de $60^{\circ} \mathrm{C}$. 0 polipropileno virgem (PPV) foi processado nas mesmas condições das blendas.

A Tabela 1 ilustra as composições desenvolvidas das blendas com as proporções em massa (\%).

Tabela 1. Composições das blendas com as proporções em massa (\%).

\begin{tabular}{|c|c|c|}
\hline Material & Virgem (\%) & Reciclado (\%) \\
\hline PPV & 100 & - \\
\hline PPV/PP20\%R & 80 & 20 \\
\hline PPV/PP40\%R & 60 & 40 \\
\hline PPV/PP60\%R & 40 & 60 \\
\hline
\end{tabular}

Fonte: Autoria própria.

O PPV e as blendas foram obtidas por extrusão e então moldados por meio de injeção em uma injetora Arburg, modelo Allrounder 207C Golden Edition para obtendo-se os corpos de prova de impacto, tração e flexão, segundo as normas ASTM D256, D638 e D790, respectivamente. As especificações de moldagem foram: perfil de temperatura $185^{\circ} \mathrm{C}$ (constante em todas as zonas); temperatura do molde de $20^{\circ} \mathrm{C}$; pressão de injeção e recalque, 1000 e 500 bar, respectivamente.

\subsection{CARACTERIZAÇÃO DOS ENSAIOS}

0 ensaio de resistência ao impacto Izod foi realizado em 10 corpos de prova entalhados segundo a norma ASTM D256, em um aparelho da marca Ceast modelo Resil 5,5 J, operando com martelo de 2,75 J, em temperatura ambiente $(23 \pm 2)^{\circ} \mathrm{C}$.

Os testes de flexão foram realizados em uma máquina de ensaio universal da marca EMIC DL 2000, segundo a norma ASTM D790, operando em modo de flexão em três pontos a uma velocidade de 1,6 $\mathrm{mm} / \mathrm{min}$, separação entre os apoios de $40 \mathrm{~mm}$ e célula de carga de $2 \mathrm{kN}$. Os testes foram conduzidos à temperatura ambiente e os resultados analisados com uma média de 8 corpos de prova.

Os ensaios de tração foram realizados em corpos de prova injetados segundo a norma ASTM D638, utilizando uma máquina de ensaios universal da marca EMIC DL 2000, com velocidade de carregamento de $5 \mathrm{~mm} / \mathrm{min}$ e célula de carga de $2 \mathrm{kN}$. Os testes foram conduzidos à temperatura ambiente e os resultados analisados a partir da média de 5 corpos de prova.

A análise de calorimetria exploratória diferencial (DSC) foi realizada em um aparelho DSC Q20 da TA Instruments, sob as seguintes condições: aquecimento da temperatura de aproximadamente 30 até 250 ${ }^{\circ} \mathrm{C}$, a uma taxa de aquecimento de $10 \stackrel{\circ}{\circ} \mathrm{C} / \mathrm{min}$, sob atmosfera de nitrogênio $(50 \mathrm{~mL} / \mathrm{min})$, rampa de $1 \mathrm{~min}$ de isoterma. 0 resfriamento foi realizado nas mesmas condições anteriores, partindo-se de 250 até $30 \stackrel{\circ}{\circ}$. Foram utilizadas amostras de cerca de $5 \mathrm{mg}$, previamente pesadas em balança analítica e acondicionadas em panelinhas de alumínio fechadas.

\section{RESULTADOS E DISCUSSÃO}

\subsection{CALORIMETRIA EXPLORATÓRIA DIFERENCIAL (DSC)}

0 PP virgem e as misturas PP virgem/PP reciclado foram analisadas por calorimetria exploratória diferencial (DSC), visando avaliação de suas propriedades térmicas. Na Tabela 2 são apresentados os 
resultados obtidos por DSC referentes ao grau de cristalinidade (Xc), as temperaturas de fusão (Tm) e de cristalização (Tc) e os calores de fusão ( $\Delta \mathrm{Hf}$ ) para o componente puro (PP virgem) e para as misturas.

Os valores de cristalinidade (Xc) das amostras em estudo foram determinados utilizando o calor de fusão ( $\Delta$ Ho) de 209 J.g-1 para o PP $100 \%$ cristalino [9], conforme a Equação (I), onde $\Delta$ Ho é a entalpia de fusão do material $100 \%$ cristalino, $\Delta$ Hf é a entalpia de fusão das amostras.

$$
\mathrm{Xc}=\frac{\Delta H f}{\Delta H o} \times 100 \%
$$

Tabela 2. Parâmetros de fusão e de cristalização do polipropileno (PPv) e das blendas PPv/PP reciclado.

\begin{tabular}{|c|c|c|c|c|}
\hline \multicolumn{2}{|c|}{ Amostras } & $\mathrm{Tm}\left({ }^{\circ} \mathrm{C}\right)$ & $\mathrm{TC}\left({ }^{\circ} \mathrm{C}\right)$ & \multicolumn{2}{c|}{ XC (\%) $(\mathrm{J} / \mathrm{g})$} \\
\hline PPV & 163,7 & 122,9 & 69,3 & 33,1 \\
\hline PPV/PP (20\% reciclado) & 164,9 & 122,9 & 72,78 & 34,8 \\
\hline PPV/PP (40\% reciclado) & 165 & 123 & 83,23 & 39,8 \\
\hline PPV/PP (60\% reciclado) & 163,9 & 122,9 & 84 & 40,2 \\
\hline
\end{tabular}

$\mathrm{Tm}=$ Temperatura do pico de fusão; $\Delta \mathrm{Hf}=$ Entalpia de fusão; Xc = Grau de cristalinidade.

Fonte: Autoria própria.

De acordo com a Tabela 2, o percentual do grau de cristalinidade para o PP virgem foi de 33,1\% com temperatura de fusão em torno de $163,7^{\circ} \mathrm{C}$. Ao analisar as temperaturas de cristalização (TC), nota-se que praticamente os valores de TC não apresentaram variações significativas entre o PPV e as misturas $\mathrm{PPV} / \mathrm{PP}$ reciclado. Todavia pode ser observado um aumento no grau de cristalinidade à medida que aumenta a proporção de PP reciclado, sendo mais pronunciado com 60\%. Tal comportamento deve-se ao efeito do PP reciclado apresentar possivelmente uma massa molar menor quando comparado com a resina virgem utilizada e, consequentemente, reduzindo a viscosidade, o que favorece o aumento do grau de cristalinidade. Os resultados da calorimetria exploratória diferencial corroboram com as propriedades mecânicas.

\subsection{ENSAIO DE RESISTÊNCIA À TRAÇÃO}

A Tabela 3 apresenta os resultados das propriedades tração do PP virgem e as misturas PP/PPr em função do aumento do teor de reciclado.

Tabela 3. Propriedades de tração do polipropileno virgem (PPv) e das misturas binárias (PPv/PPr) em função do aumento do material reciclado.

\begin{tabular}{|c|c|c|c|}
\hline Amostras & Módulo Elástico (MPa) & Tensão Máxima (MPa) & Alongamento (\%) \\
\hline PPV & $452,42 \pm 12,22$ & $21,57 \pm 0,16$ & $494,73 \pm 7,36$ \\
\hline PPV/PP (20\% rec.) & $458,07 \pm 24,00$ & $20,44 \pm 0,23$ & $446,97 \pm 11,92$ \\
\hline PPV/PP (40\% rec.) & $476,52 \pm 38,54$ & $20,72 \pm 0,10$ & $240,53 \pm 15,25$ \\
\hline PPV/PP (60\% rec.) & $532,10 \pm 23,87$ & $21,17 \pm 0,18$ & $70,32 \pm 6,89$ \\
\hline
\end{tabular}


Conforme se pode observar, a introdução do PP reciclado no PP virgem levou, dentro da faixa de concentração em estudo, ao aumento do módulo elástico, sugerindo que as misturas tornaram-se mais frágeis e corroborando com os resultados de resistência ao impacto. Sabe-se que o grau de cristalinidade pode ter influência significativa sobre as propriedades mecânicas. Para os polímeros semicristalinos, o módulo de elasticidade aumenta significativamente com o grau de cristalinidade.

Na Tabela 3, pode-se notar uma diminuição da deformação na ruptura das misturas, com o aumento da porcentagem de PP reciclado. Essa menor deformação acarreta em um aumento do módulo elástico do material, ou seja, este se torna mais rígido. É importante pontuar que, as misturas (PP/PP reciclado) apresentaram valores de deformação na ruptura menor quando comparado ao PP virgem, produzindo uma curva tensão-deformação com uma menor área interna, o que confirma a menor capacidade de absorção de energia desses materiais. Todavia, o material com 20\% de PP reciclado apresentou um comportamento próximo ao do virgem. Acima de $20 \%$, pode-se perceber uma brusca diminuição no alongamento, inviabilizando a utilização para aplicação de para-choques.

Fica evidenciado que, para a tensão máxima, o aumento do teor de polipropileno reciclado não influência significativamente nesta propriedade. Nesse caso, obteve-se propriedades mecânicas de resistência à tração comparáveis às do PP virgem, que foi processado e moldado em condições idênticas às das misturas. Para a maioria dos fabricantes de para-choques, a tensão máxima de tração deve estar em cerca de $20 \mathrm{MPa}$ [10]. Através dos valores expostos na Tabela 3, nota-se que a resistência à tração de todos os materiais encontra-se próximo ao valor exigido.

\subsection{ENSAIO DE RESISTÊNCIA À FLEXÃO}

A Figura 6 apresenta os resultados de resistência e módulo à flexão do PP virgem e das misturas $P P / P P r$ em função do aumento do teor de reciclado, respectivamente.

Figura 6 - Resistência e módulo à flexão do PP virgem e das misturas PP/PPr em função do aumento do teor de reciclado, respectivamente.

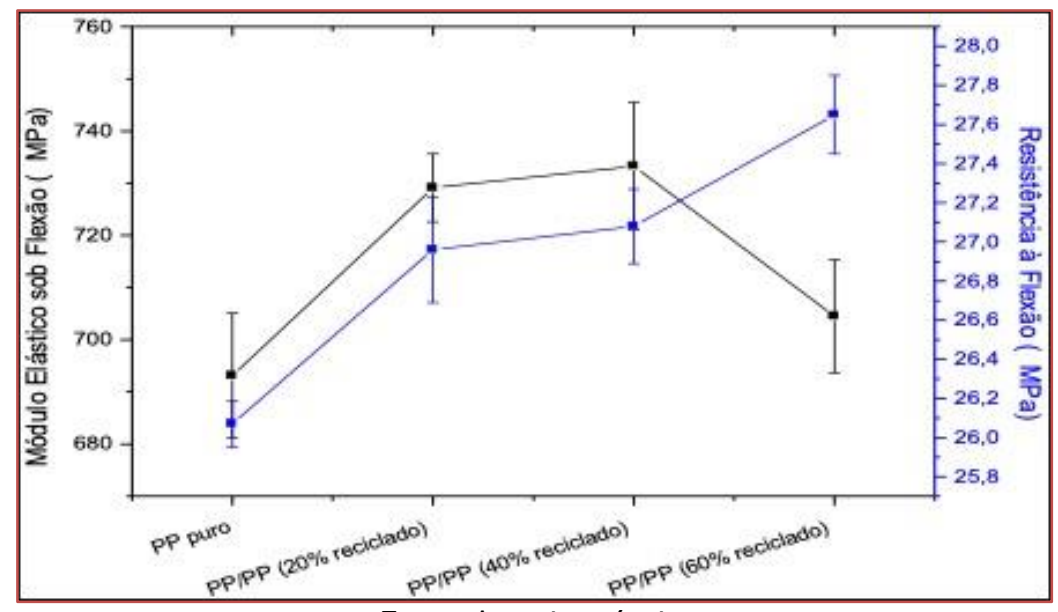

Fonte: Autoria própria.

Verifica-se na Figura 6, que o PP virgem apresentou o menor valor de módulo elástico. A introdução de até $40 \%$ de PP reciclado no PP virgem levou a um aumento no módulo elástico sob flexão em relação ao PP virgem. Dentro da faixa de composição investigada, nota-se que $60 \%$ de PP reciclado ficou dentro da margem de erro experimental em comparação ao PP virgem e, neste caso, obteve-se propriedade de módulo sob flexão comparáveis. A razão para a inversão do comportamento do módulo elástico da mistura contendo $60 \%$ de reciclado não é clara, pois o esperado era que o módulo sob flexão seguisse a tendência de aumento. Para a resistência à flexão, verifica-se um aumento à medida que eleva a quantidade de PP reciclado, sendo mais pronunciado o aumento ao utilizar 60\%. As composições com 20 e $40 \%$ de reciclados estão dentro da margem do erro experimental, sugerindo que não há diferenças significativas entre si. Como os parâmetros mecânicos flexivos não são significativamente modificados independentemente da quantidade presente de reciclado no material, a blenda mais indicada, analisando somente esse aspecto, seria a que possuir maior percentual de reciclado. 
No geral, os resultados de flexão confirmam o aumento do grau de fragilidade dos materiais desenvolvidos.

\subsection{ENSAIO DE RESISTÊNCIA AO IMPACTO}

A Figura 7 apresenta os resultados de resistência ao impacto do PP virgem e das misturas PP/PPr em função do aumento do teor de reciclado.

Figura 7 - Resistência ao impacto do polipropileno virgem (PPv) e das misturas binárias (PPv/PPr) em função do aumento do material reciclado.

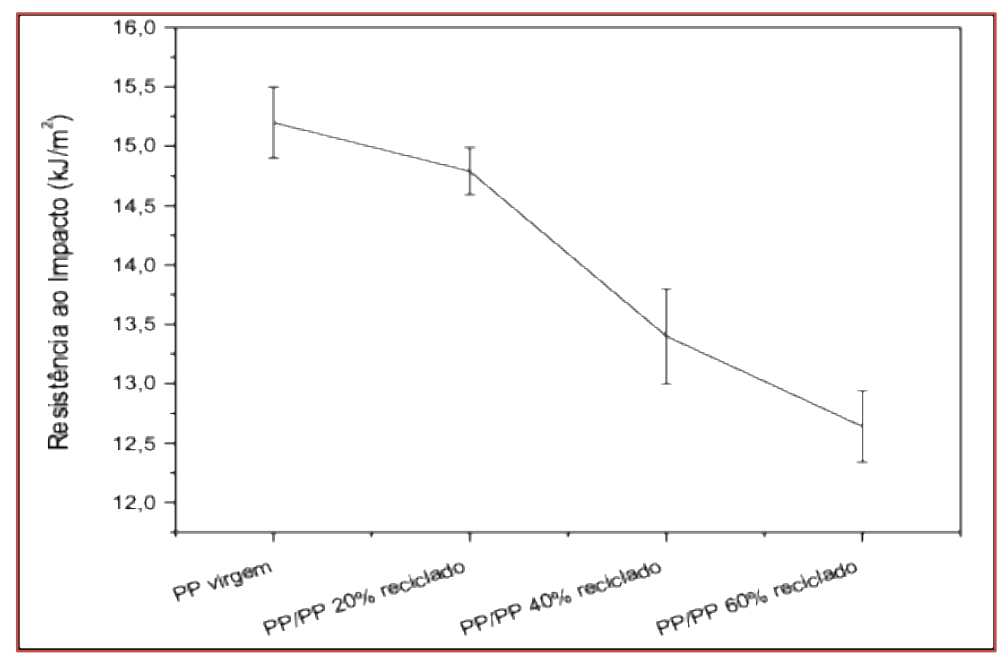

Fonte: Autoria própria.

Conforme se pode observar, houve um decréscimo na resistência ao impacto com o aumento do teor de polipropileno reciclado, indicando um aumento na fragilidade das misturas em comparação ao PP virgem. Para a produção de para-choques é necessário uma resistência ao impacto Izod mínima de impacto de $12,8 \mathrm{~kJ} / \mathrm{m}^{2}$ [10], [11]. Observando os valores expostos na Figura 7, pode-se perceber que, à exceção da mistura contendo $60 \%$ de reciclado, todas as outras misturas apresentaram valor superior ao exigido.

O ensaio de impacto confirmou a fragilização do PP, principalmente com misturas acima de $20 \%$ de reciclado, corroborando com os resultados de cristalinidade observados por DSC.

\section{CONCLUSÕES}

- Todas as blendas atenderam as exigências para fabricação de para-choques na tensão máxima de tração;

- $\quad$ As blendas apresentaram boas propriedades de flexão;

- $\quad$ A blenda PP virgem/PP (60\% reciclado) foi à única reprovada no teste de impacto, indicando que o alto teor de material reciclado fragiliza acentuadamente;

- $\quad 0$ grau de cristalinidade (Xc) tende a aumentar com aumento do teor de reciclado, consequentemente as propriedades de resistência ao impacto e alongamento reduziram;

- $\quad$ Os resultados evidenciam que é possível obter materiais com boas propriedades, podendo agregar valor a um material que seria descartado.

Fica evidente por meio dos resultados que a mistura PP virgem/PP 20\% reciclado seria uma excelente escolha para fabricação de para-choques pelas indústrias de automóveis, visto que possui bom balanço de rigidez e resistência ao impacto. A mesma satisfaz todas as exigências da norma com elevada margem de segurança. 
0 alto teor de material reciclado reduz o custo do preço final do para-choques, pois como o polipropileno reciclado é em média 40\% mais barato, a indústria automotiva economizaria cerca de 12\% ao utilizar a blenda de $20 \%$ de PP reciclado, além de colaborar no desenvolvimento de materiais que contribuem para preservar o meio ambiente.

\section{REFERÊNCIAS}

[1] LANDiM, A. P. M.; BERNARDO, C. O.; MARTINS, I. B. A.; FRANCISCO, M. R.; SANTOS, M. B.; MELO, N. R. Sustentabilidade quanto às embalagens de alimentos no Brasil. Polímeros: Ciência e Tecnologia, v. 26, n. especial, p. 82-92, 2016

[2] FERREIRA, C. T.; FONSECA, J. B..; SARON, C. Reciclagem de rejeitos de poli(tereftalato de etileno) (PET) e de poliamida (PA) por meio de extrusão reativa para a preparação de blendas. Polímeros: Ciência e Tecnologia, v. 21, n. 2, p. 118-122, 2011.

[3] RIBEIRO, V. F.; DOMINGOS J.R. N. S.; RIEGEL I. C. Estudo da recuperação das propriedades de poliestireno de alto impacto (HIPS) através da incorporação de borracha termoplástica tipo estireno-butadieno-estireno (SBS). Polímeros: Ciência e Tecnologia, v. 22, n. 2, p. 186-192, 2012.

[4] SILVA, E. P.; NETO, J. M. M. Possibilidades de melhorias ambientais no processo de reciclagem do polietileno. Polímeros: Ciência e Tecnologia, v. 26, n. especial, p. 49-54, 2016.

[5] ARAUJO, L. M. G.; MORALES, A. R. Compatibilization of recycled polypropylene and recycled poly (ethylene terephthalate) blends with SEBS-g-MA. Polímeros: Ciência e Tecnologia, v. 28, n. 1, p. 84-91, 2018.

[6] PEREIRA, L. M.; CORRÊA, A. C.; FILHO, M. S. M. S.; ROSA, M. F.; ITO, E. N. Rheological, morphological and mechanical characterization of recycled poly (Ethylene Terephthalate) blends and composites. Materials Research, $\mathrm{v}$. 20, n. 3, p. 791-800, 2017.

[7] SANTOS, L. S.; SILVA, A. H. M. F. T.; PACHECO, E. B. A. V.; SILVA, A. L. N. Estudo do efeito da adição de PP reciclado nas propriedades mecânicas e de escoamento de misturas de PP/EPDM. Polímeros: Ciência e Tecnologia, v. 23, n. 3, p. 389-394, 2013.

[8] Garcia, A.; Spim, J. A.; Santos, C. A.; Ensaios dos materiais. 2. ed. São Paulo. LTC Editora, 2000-247 p.

[9] OLIVEIRA, R. V. N.; FERREIRA, C. L.; PEIXOTO, L. J. F.; BIANCHI, O.; SILVA, P. A.; DEMORI, R.; SILVA, R. P.; VERONESE, V. B. Mistura polipropileno/poliestireno: Um exemplo da relação processamento-estrutura-propriedade no ensino de polímeros. Polímeros: Ciência e Tecnologia, v. 23, n. 1, p. 91-96, 2013.

[10] FERNANDES, B. L.; DOMINGUES, A. J. Caracterização mecânica de polipropileno reciclado para a indústria automotiva. Polímeros: Ciência e Tecnologia, v. 17, n. 2, p. 85-87, 2007.

[11] Verification of pendulum impact-testing machines: Charpy, Izod and tensile impact testing; ISO 13802:1999, Plastics; 2008. 


\section{Capítulo 21}

Eletrofiação de poli ( $\varepsilon$-caprolactona) contendo óleo de andiroba (carapa guianensis aublet)

Tainah Vasconcelos Pessoa

João de Deus Pereira de Moraes Segundo

Maria Oneide Silva de Moraes

Rosemeire dos Santos Almeida

Marcos Akira d'Ávila

Karen Segala

Walter Ricardo Brito

Rudyere Nascimento Silva

Resumo: A poli ( $\varepsilon$-caprolactona) (PCL) é um polímero da classe de poliésteres alifáticos, que é visto como um dos polímeros biodegradáveis mais importantes da atualidade. No presente trabalho são produzidas e caracterizadas as microfibras de PCL funcionalizadas com o anti-inflamatório óleo de andiroba mediante o emprego da técnica de eletrofiação. As membranas receberam caracterizações morfológicas por microscopia eletrônica de varredura (MEV), química por espectroscopia FTIR e molhabilidade. Foram estudados a influência da concentração do óleo $(0,1 ; 0,4 ; 0,7 ; 1 ; 5 ; 10$ e 25\%wt) nas caraterísticas finais das fibras produzidas. Deste modo, foi possível identificar que não houve alterações morfológicas e nem o surgimento de pérolas nas fibras eletrofiadas. 0 uso excessivo de óleo de andiroba na solução de PCL resultou em membrana oleosa e não impediu a formação das fibras.

Palavras-chave: Eletrofiação; PCL; Óleo de Andiroba; Carapa Guianensis Aublet. 


\section{INTRODUÇÃO}

A poli ( $\varepsilon$-caprolactona) (PCL) é um polímero da classe de poliésteres alifáticos que apresenta propriedades interessantes tais como biodegradabilidade e biocompatibilidade. Visto como um dos polímeros biodegradáveis mais importantes da atualidade é, um polímero semicristalino, hidrofóbico, boas propriedades mecânicas, facilidade de processamento à baixa temperatura de fusão e afinidade de mistura com outros polímeros(1).

A PCL é considerada eletrofiável do inglês "electrospinnable" e tem sido bastante utilizado na obtenção de fibras por meio da eletrofiação, que é uma técnica capaz de produzir fibras poliméricas em dimensões micrométricas e nanométricas por meio de um jato carregado eletricamente. A deposição contínua das fibras, umas sobre as outras, formam uma membrana porosa, leve e flexível, o que é interessante para aplicações nas áreas de sensores, biomedicina, engenharia tecidual e farmacologia $(1,2)$.

A Carapa guianensis Aublet da família Meliaceae é uma árvore comumente encontrada na região amazônica, o óleo extraído da semente desta árvore conhecido como óleo de andiroba, é antialérgica e ótima para cicatriação de feridas, apresenta importantes aplicações medicinais e é considerado um excelente anti-inflamatório $(3,4,5)$.

Neste trabalho, o objetivo foi encontrar uma concentração máxima de óleo de andiroba que seja eletrofiável juntamente com a PCL e realizar caracterizações morfológica, química e estudo de molhabilidade por ângulo de contato.

\section{MATERIAIS E MÉTODOS}

\subsection{MATERIAIS}

Foi utilizado poli ( $\varepsilon$-caprolactona) (PCL, MM $=80.000 \mathrm{~g} / \mathrm{mol}$ ) fornecido pelo Sigma Aldrich, óleo de andiroba (OA) (Shelf life, Lote R20007), clorofórmio (99\% de pureza) fornecido pela Biotec e Acetona (99,5\% de pureza) fornecida pela Synth. Todos os produtos foram utilizados como recebidos.

\subsection{PREPARO DAS SOLUÇõES}

Em um frasco foram adicionados os solventes acetona e clorofórmio na proporção de 1:1 em massa, em seguida, a mistura foi agitada por um agitador magnético por 15 minutos. Posteriormente, 13,6\% de PCL em pellets foi adicionado no frasco, vedou-se e levou-se à agitação por 16hrs. Após o preparo da solução de PCL foram adicionadas diferentes concentrações $(0,1 ; 0,4 ; 0,7 ; 1 ; 5 ; 10$ e 25wt\%) do OA sob a agitação mecânica por 40 minutos.

\subsection{ELETROFIAÇÃO DAS SOLUÇÕES DE PCL/OA}

Soluções de PCL/AO com concentrações distintas foram introduzidas em uma seringa descartável de polietileno da marca SR, a seringa foi acomodada em uma bomba de infusão altamente sensível (SAMTRONIC, ST670) e ajustada para aplicar uma vazão de $8 \mathrm{ml} / \mathrm{h}$, na ponta da seringa foi conectado um capilar metálico com diâmetro de $0,8 \mathrm{~mm}$. 0 anteparo utilizado foi um coletor metálico rotativo aterrado com rotação fixa de 450 RPM, o coletor metálico foi recoberto com papel alumínio para posterior remoção das membranas. A distância da ponta da agulha ao anteparo foi de $18 \mathrm{~cm}$. A tensão aplicada variou de $15 \mathrm{kv}$ - 18kv conforme a estabilidade do jato ou cone de Taylor observados durante a eletrofiação. A tensão foi proveniente de uma fonte de alta tensão (3AS Engenharias) com capacidade máxima de 30kv. 0 eletrodo positivo da fonte de alta tensão foi conectado na ponta da agulha enquanto que o negativo foi conectado no coletor rotativo. Os parâmetros ambientais registrados foram: umidade $U=51 \pm 1,2 \%$ e temperatura $\mathrm{T}=24 \pm 1,5^{\circ} \mathrm{C}$.

\subsection{EQUIPAMENTOS DE CARACTERIZAÇÕES}

As membranas eletrofiadas receberam caracterização morfológica por microscopia eletrônica de varredura - MEV (ZEISS, Evo MA-15). Antes da análise, as amostras foram cortadas nas dimensões de $1 \mathrm{X} 1 \mathrm{~cm}$ e colocadas sobre o stub com a ajuda de uma fita de carbono, em seguida as amostras receberam revestimento com uma fina camada de ouro por um sputter (BAL TEC, CPD 050). 
Foi realizado o estudo estatístico das medidas dos diâmetros das fibras que foram representadas em micrometros $(\mu \mathrm{m})$. 0 software analisador de imagem ImageJ (versão gratuita) foi utilizado para a obtenção das medidas dos diâmetros das fibras. Foram realizadas 100 medidas dos diâmetros das fibras em regiões diferentes para cada imagem de MEV.

A caracterização química foi feita por espectroscopia na região do infravermelho - FTIR (NICOMET, IR 200) na faixa de 400 à $4000 \mathrm{~cm}-1$. As amostras foram preparadas com pastilha de brometo de potássio (KBr).

O ensaio de molhabilidade e as medidas do ângulo de contato foram feitos utilizando um microscópio digital (DINO - lite plus) com capacidade de ampliação de 1000X. Colocou-se cuidadosamente uma gota de água deionizada de $10 \mu \mathrm{L}$ à temperatura ambiente sobre a superfície das amostras, o comportamento da gota de água foi observado por 120 segundos. As medidas do ângulo de contato foram obtidas com o auxílio do software ImageJ.

\section{RESULTADOS E DISCUSSÕES}

\subsection{MORFOLOGIA E ESTUDO ESTATÍSTICO DOS DIÂMETROS DAS FIBRAS}

A Figura 1 mostra as imagens micrográficas de MEV das membranas obtidas com diferentes concentrações de OA juntamente com as respectivas distribuições dos diâmetros das fibras. A membrana sem adição de OA apresentou diâmetro médio e desvio padrão de 4,19 $\pm 2,18 \mu \mathrm{m}$. A pequena quantidade de $0 \mathrm{~A}(0,1 \mathrm{wt} \%)$ que foi acrescentada na solução de PCL resultou na diminuição do diâmetro médio e desvio padrão das

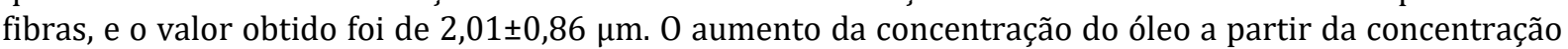
de 0,1 até $5 \%$ wt não resultou em reduções expressivas nos diâmetros das fibras. Este efeito pode ser observado comparando os valores dos diâmetros médios e os desvios padrões no estudo estatístico das fibras. Este fato pode ter ocorrido devido a boa solubilidade do OA na solução de PCL.

As quantidades de $\mathrm{OA}$ associadas às concentrações 10 e $25 \mathrm{wt} \%$ resultaram em fibras com diâmetros

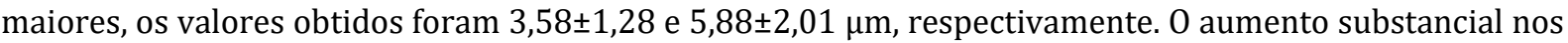
diâmetros está diretamente relacionado com o aumento da concentração do $0 A$. 0 comportamento aleatório das fibras foi predominante em todos os casos, isto confere às membranas a presença de porosidades, que pode ser aumentada com a diminuição dos diâmetros das fibras(6). Esta morfologia é típica em membranas produzidas em coletores rotativos com rotações baixas(7).

As membranas com as concentrações de 10 e 25wt\% de OA apresentaram aspecto oleoso, ou seja, foi possível observar visualmente o excesso de OA nas membranas, entretanto, estas concentrações elevadas de OA não impediram a formação das membranas sobre o coletor.

Figura 1. Imagens micrográficas de MEV em magnitudes de 500X e 5000X e estudo estatístico dos diâmetros das fibras com a) 0; b) 0,1; c) 0,4; d) 0,7; e) 1; f) 5; g) 10 e h) 25wt\% de OA, respectivamente.

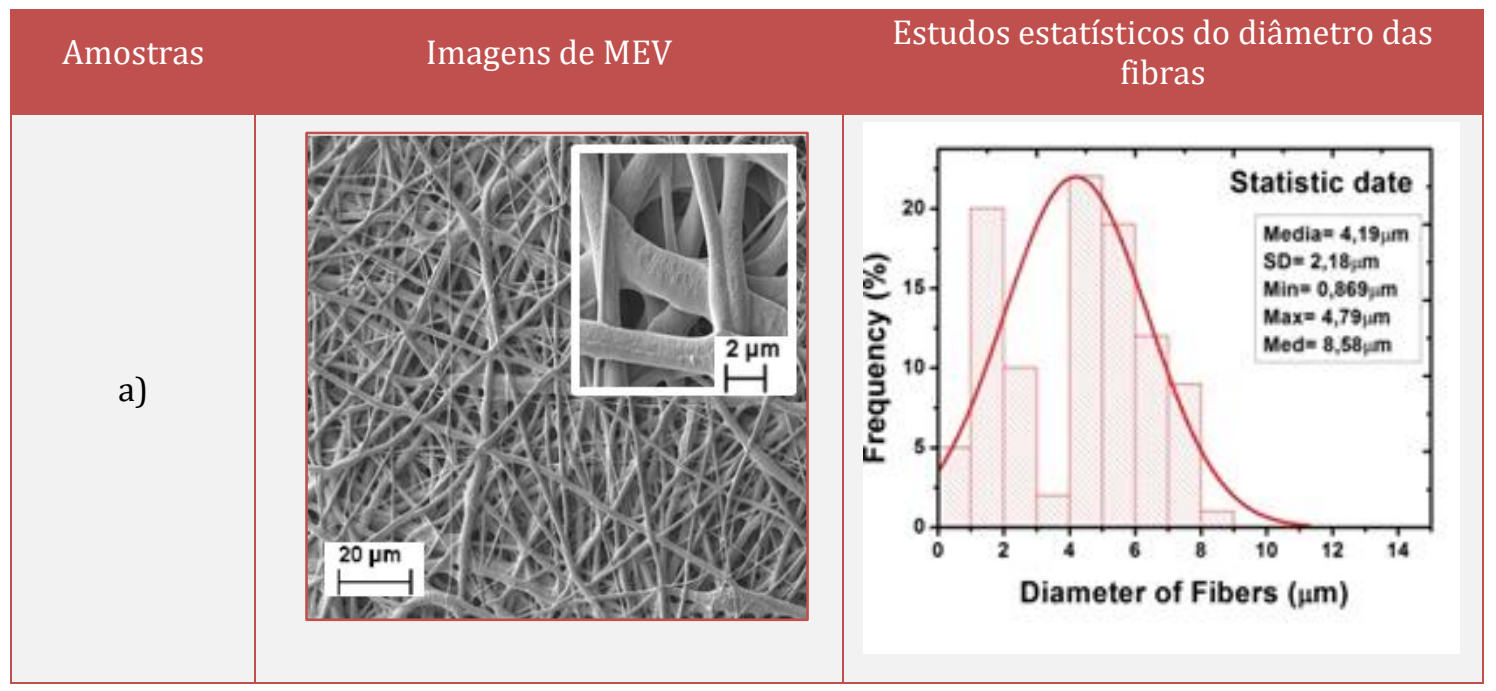


(continuação...)

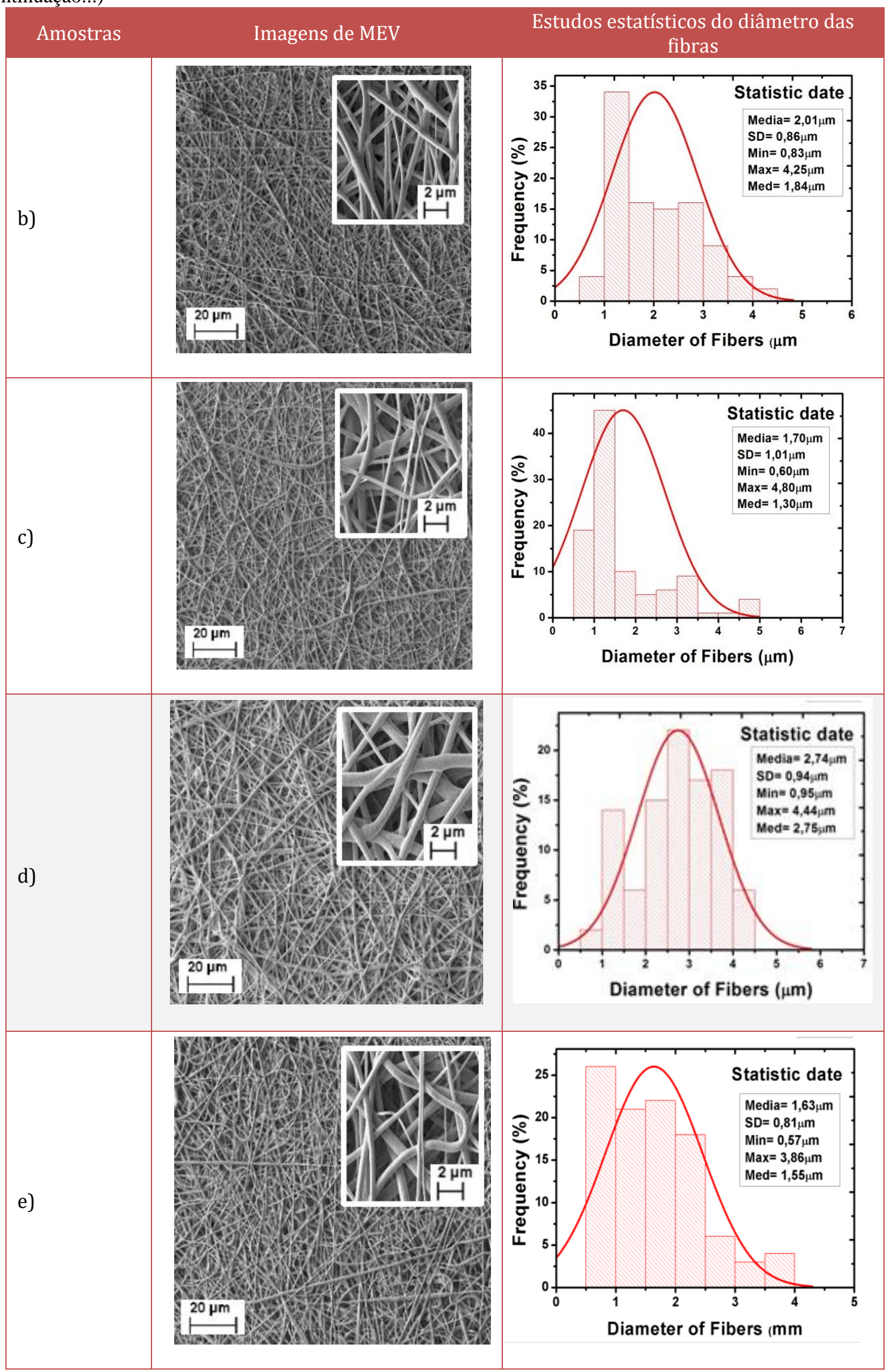


(continuação...)

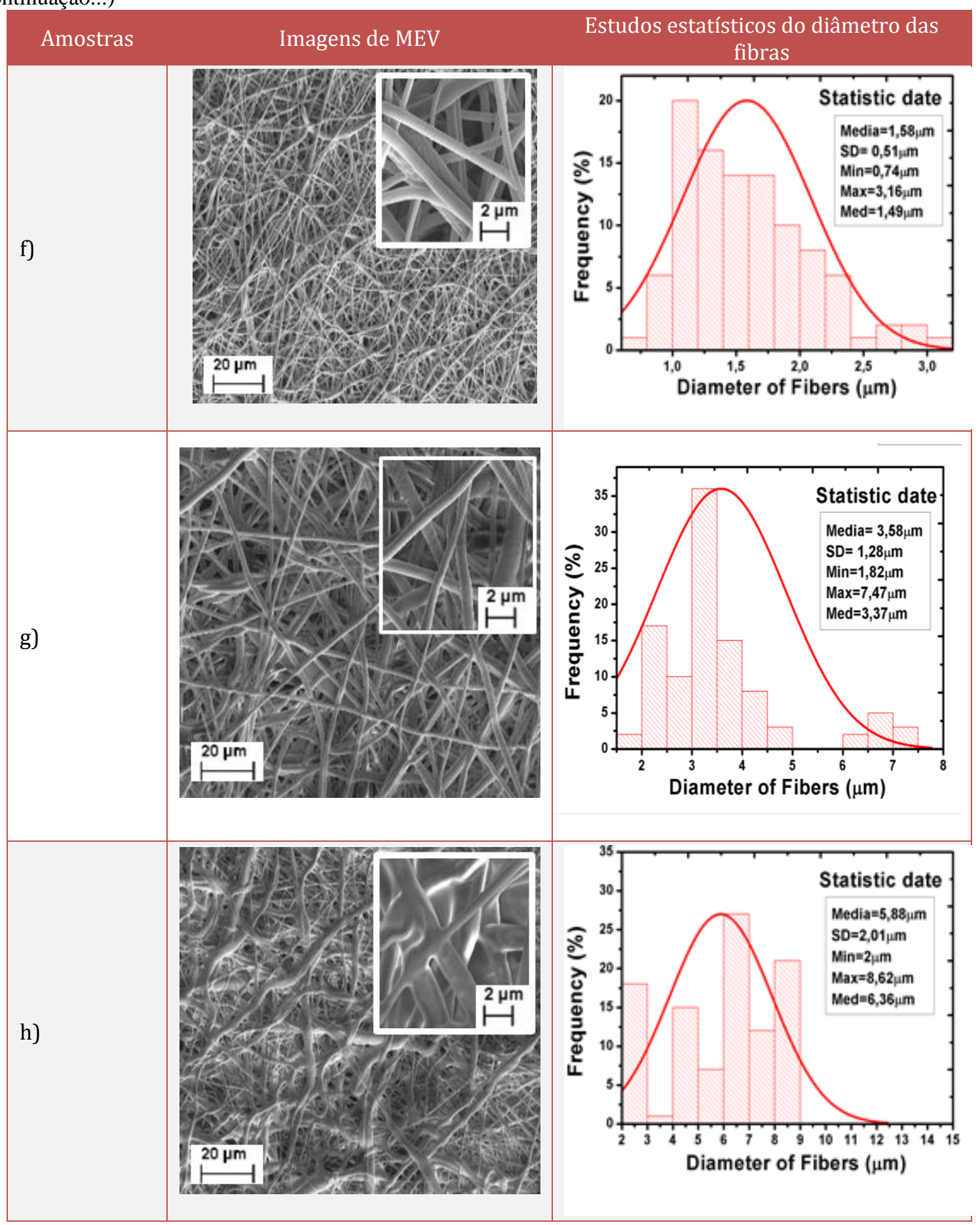

\subsection{CARACTERIZAÇÃO QUÍMICA - FTIR}

Foi realizada a caracterização química da PCL quanto aos modos vibracionais associadas as bandas presentes no espectro de FTIR. Na Figura 2, foram encontradas as bandas vibracionais em 2945,86, 2870,50 e 1724,88 cm-1 que correspondem ao estiramento assimétrico de $\mathrm{CH} 2$, simétrico de $\mathrm{CH} 2$ e carbonila $(\mathrm{C}=0)$, respectivamente. A banda vibracional em $1293 \mathrm{~cm}-1$ corresponde aos estiramentos de C$\mathrm{C}$ e C-O que ocorrem na fase cristalina, enquanto que a banda vibracional em $1110 \mathrm{~cm}-1$ corresponde aos estiramentos de C-C e C-O associados à fase amorfa da PCL. Os estiramentos, assimétrico e simétrico da ligação C-0-C, também foram observados nas bandas vibracionais em 1239,69 e 1167,14 cm-1, respectivamente. As bandas vibracionais observadas neste trabalho estão de acordo a literatura(8). 
As características químicas do OA estão apresentadas nos espectros de FTIR na Figura 2. A posição da banda vibracional em $3006 \mathrm{~cm}-1$ está associada ao estiramento de $=\mathrm{C}-\mathrm{H}$ (trans), assim como os modos vibracionais em 2924 e $2854 \mathrm{~cm}-1$ que correspondem aos estiramentos de $\mathrm{CH} 3$ e $\mathrm{CH} 2$, respectivamente. A banda $1747 \mathrm{~cm}-1$ é referente ao grupo éster $(-\mathrm{C}=0), 1658 \mathrm{~cm}-1$ está associado ao estiramento de $\mathrm{C}=\mathrm{C}$ e o dobramento angular de CH2 foi observado em $1466 \mathrm{~cm}-1$. A ligação simétrica de CH3 foi identificada em $1376 \mathrm{~cm}-1$, enquanto que os estiramentos de -C-O foram observados em 1164 e $1044 \mathrm{~cm}-1$. As ligações trans e cis de $-\mathrm{CH}=\mathrm{CH}$ - (fora do plano) foram encontradas em 947 e $875 \mathrm{~cm}-1$, respectivamente(9).

Na Figura 2 é mostrado os espectros de FTIR das membranas eletrofiadas de PCL com diferentes concentrações do OA. De forma geral, a intensidade das bandas vibracionais das membranas eletrofiadas aumentam à medida que as concentrações de OA aumentam. Os espectros de FTIR para as membranas com concentrações de 1,0 até 25\%wt de OA apresentam uma banda vibracional em torno de $3006 \mathrm{~cm}-1$ atribuída ao estiramento de $=\mathrm{C}-\mathrm{H}$ (trans) pertencente ao $\mathrm{OA}$ em que foi observado um aumento gradual de intensidade. Entretanto, para concentrações menores de 1,0\% não foi observado esta banda. Além disso, foi possível observar as sobreposições de bandas dos espectros de PCL e do OA, indicando uma boa incorporação do OA nas fibras da membrana de PCL.

Figura 2. Espectros de FTIR da PCL, óleo de andiroba puro e das membranas de PCL com diferentes concentrações de óleo de andiroba.

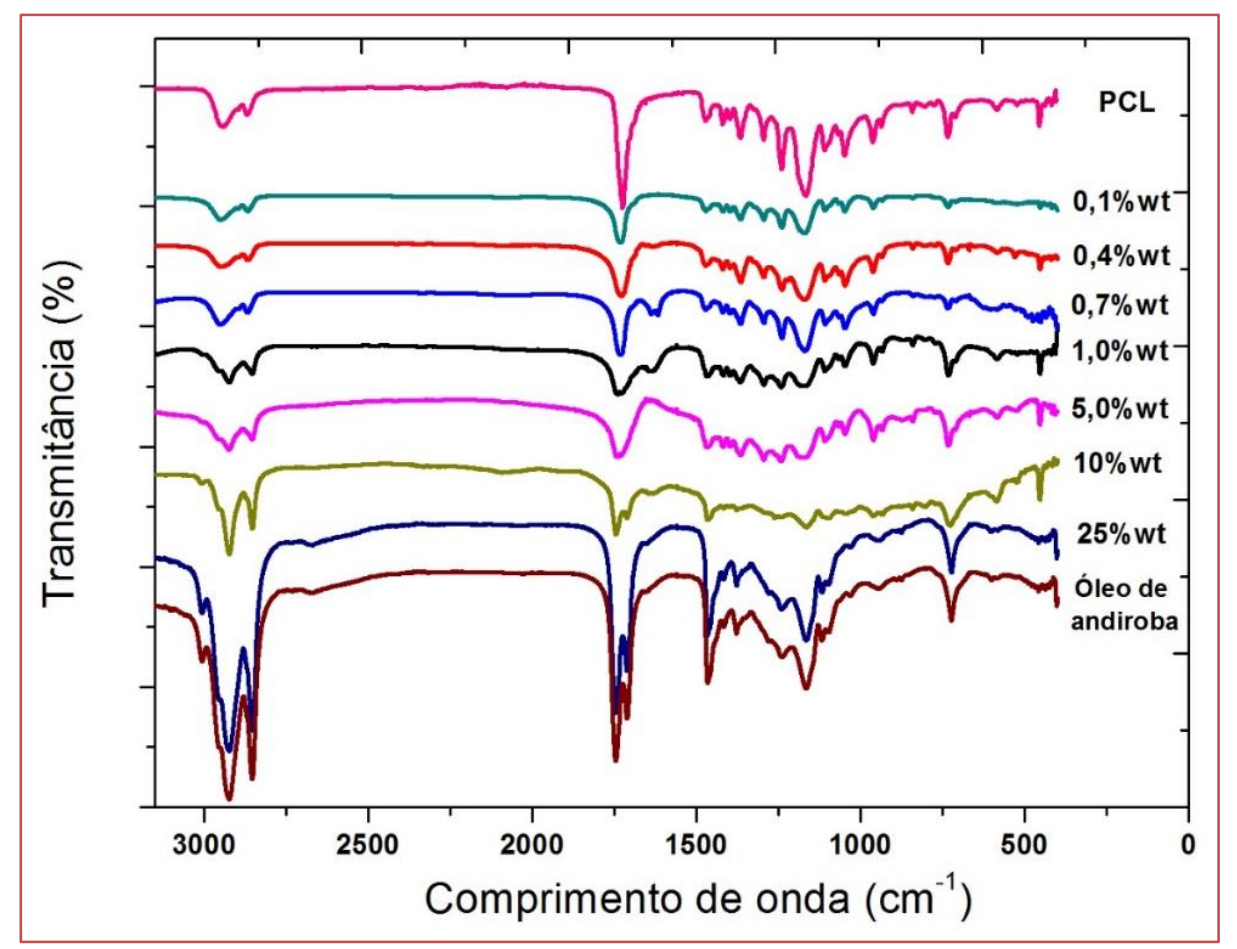

\section{3 ÂNGULO DE CONTATO}

As medidas dos ângulos de contato em função do tempo estão representadas na Figura 3. As adições do A0 com concentrações $0 ; 0,1 ; 0,4 ; 0,7 ; 1$ e 5\%wt apresentaram ângulo de contato de $142 \pm 0,30,128 \pm 0,20 ; 129$ $\pm 0,10 ; 124 \pm 0,130 ; 113 \pm 0,22$ o e $109 \pm 0,40$, respectivamente.

A gota de água sobre a membrana com concentração de 10\%wt de AO apresentou comportamento distinto, observou-se um espalhamento da gota sobre a membrana. Este resultado mostra a mudança na hidrofobicidade da membrana que pode estar relacionada com a concentração do OA. Na membrana com concentração de $25 \%$ wt de $\mathrm{AO}$, no tempo $\mathrm{t}=0 \mathrm{~s}$, observou-se o comportamento espalhado da gota de água sem apresentar mudanças significativas no tempo $t=120$ s. 0 ângulo de contato obtido foi de $51 \pm 0,1$ o que estar associado ao comportamento hidrofílico da membrana. A molhabilidade nas membranas foi influenciada pela adição do óleo de andiroba. 
Figura 3. Gráfico do ângulo de contato em função do tempo de permanência da gota de água sobre as membranas em diferentes concentrações de OA.

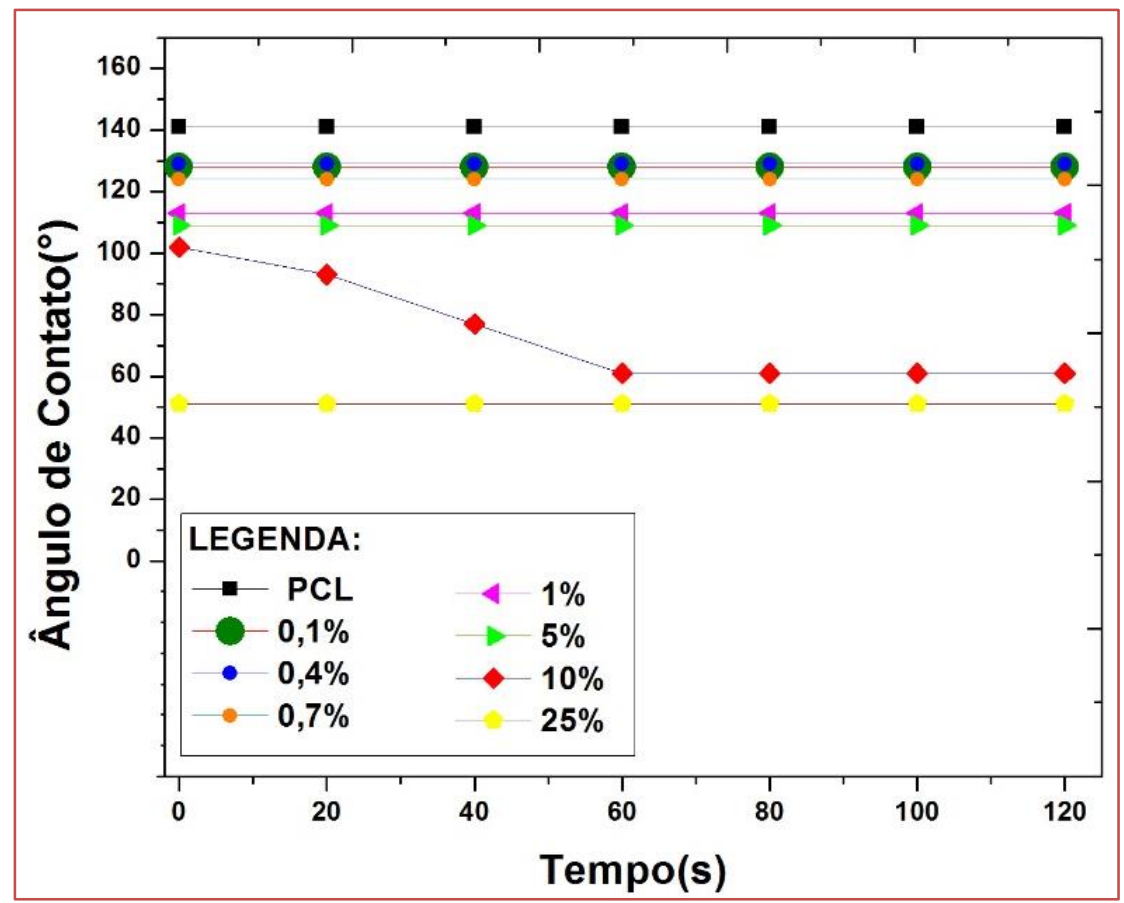

\section{CONCLUSÃO}

Fibras de PCL com óleo de andiroba foram obtidas com sucesso pelo processo de eletrofiação, o aumento da concentração de óleo interferiu no diâmetro médio das fibras que foi confirmado pelo estudo estatístico e pela caracterização morfológica. As composições químicas foram confirmadas por FTIR e o ângulo de contato mudou drasticamente com o aumento da concentração do óleo de andiroba. $\mathrm{O}$ uso excessivo de $\mathrm{OA}$ (10 e 25\%wt) não impediu o surgimento das fibras e nem a formação das membranas.

\section{AGRADECIMENTOS}

Os agradecimentos são para Fundação de Amparo à Pesquisa do Estado do Amazonas (FAPEAM), Conselho Nacional de Desenvolvimento Científico e Tecnológico (CNPq) e à Técnica em Microscopia Jackieline Souza Veras Lima do Laboratório Temático de Microscopia Óptica e Eletrônica (LTMOE).

\section{REFERÊNCIAS}

[1] GUARINO, V.; CRUZ-MAYA, L.; ALTOBELLI, R.; ABDUL KHODIR, W. K.; AMBROSIO, L.; ALVAREZ PÈREZ, M. A.; FLORES, A. A. Electrospun polycaprolactone nanofibres decorated by drug loaded chitosan nano-reservoirs for antibacterial treatments. Nanotechnology, v.28, n.50, p.505103, 2017.

[2] KATSOGIANNiS, K. A. G.; VladisAVljEVIĆ, G. T.; GEORGIAdOU, S. 2015. Porous electrospun polycaprolactone (PCL) fibres by phase separation. European Polymer Journal, v.69, p.284-295, 2015.

[3] KIMURA, V. T.; MIYASATO, C. S.; GENESI, B. P.; LOPES, P. S.; YOSHIDA, C. M. P.; SILVA, C. F. The effect of andiroba oil and chitosan concentration on the physical properties of chitosan emulsion film. Polímeros, v.26, n.2, p.168-175, 2016.

[4] MILHOMEM-PAIXÃO, S. S. R.; FASCINELI, M. L.; MUEHLMANN, L. A.; MELO, K. M.; SALGADO, H. L. C.; JOANITTI, G. A.; GRISOLIA, C. K. Andiroba Oil (Carapa guianensis Aublet) Nanoemulsions: Development and Assessment of Cytotoxicity, Genotoxicity, and Hematotoxicity. Journal of Nanomaterials, p.11, 2017.

[5] MELO, K. M.; FASCINELI, M. L.; MILHOMEM-PAIXÃO, S. S. R.; GRISOLIA, C. K.; SANTOS, A. S.; SALGADO, H. L. C.; NAGAMACHI, C. Y. 2018. Evaluation of the Genotoxic and Antigenotoxic Effects of Andiroba (Carapa guianensis Aublet) Oil and Nanoemulsion on Swiss Mice. Journal of Nanomaterials, p.8, 2018. 
[6] SEGUNDO, J. D. P. M. Influência da adição de surfactantes em fibras altamente alinhadas de poli(caprolactona) obtidas por eletrofiação. 2015, 129p. Dissertação (Mestrado em Engenharia Mecânica) - Faculdade de Engenharia Mecânica, Universidade Estadual de Campinas, UNICAMP/SP. SÃO PAULO.

[7] MEDEIROS, E.S.; MATTOSO, L.H.C.; ITO, E.N.; GREGORSKI, K.S.; ROBERTSON, G.H.; OFFEMAN, R.D.; WOOD, D.F.; William J. ORTS, W.J.; IMAM, S.H. Electrospun Nanofibers of Poly(vinyl alcohol) Reinforced with Cellulose Nanofibrils. Journal of Biobased Materials and Bioenergy. vol.2, 1-12, 2008.

[8] GURLEK, A.C.; SEVINC, B.; BAYRAK, E.; ERISKEN, C. Synthesis and characterization of polycaprolactone for anterior cruciate ligament regeneration. Materials Science and Engineering C. v.71.820-826, 2017.

[9] SANTANA, F.B.; MAZIVILA, S.J.; GONTIJO, L.C.; NETO, W.B.; POPPI, R.J. Rapid Discrimination Between Authentic and Adulterated Andiroba Oil Using FTIR-HATR Spectroscopy and Random Forest. Food Analytical Methods. vol.11,1927-1935, (2018). 


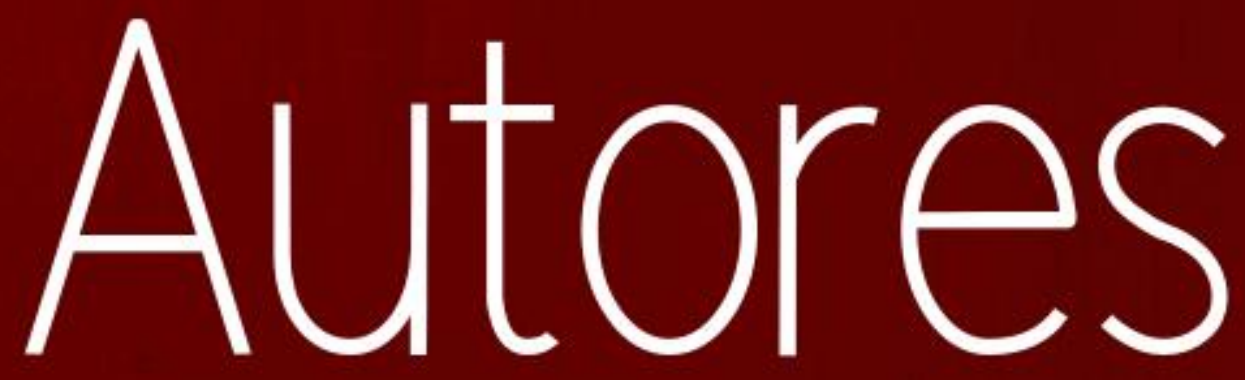




\section{ALEXANDRE DA SILVA ROCHA}

Graduou-se em Engenharia Mecânica em 1994 pela Universidade Federal do Rio Grande do Sul (UFRGS). Em 1996 formou-se Mestre em Engenharia e em 2000 obteve o título de Doutor em Engenharia pelo Programa de Pós-graduação em Engenharia de Minas, Metalúrgica e de Materiais (PPGE3M) da UFRGS (conceito CAPES 7). Foi professor e pesquisador da Universidade do Vale do Rio dos Sinos de 1999 a 2001. De 2001 a 2004 atuou como pesquisador do Materials Science Institut (Stiftung Institut fuer Werkstofftechnik, IWT) em Bremen na Alemanha, tendo participado do projeto SFB 570 - Distortion Engineering do DFG, sendo responsável por desenvolvimentos na área de Análise de Tensões Residuais. Em 2005 iniciou sua carreira na UFRGS como professor do Departamento de Metalurgia, atuando na docência, orientador de mestrado e doutorado, em ações de extensão e como pesquisador. Professor permanente do PPGE3M, suas principais linhas de atuação são a Engenharia de Superfícies, a Conformação Mecânica e a Análise de Tensões Residuais.

\section{AMBRÓSIO FLORÊNCIO DE ALMEIDA NETO}

Graduado em Engenharia Química pela UFCG (2006)e Licenciatura Plena Em Química pela Universidade Estadual da Paraíba (2002), mestrado em Engenharia Química pela UFCG (2007) e doutorado em Engenharia Química pela Universidade Estadual de Campinas (2011). Atualmente é Professor Doutor no Departamento de Desenvolvimento de Processos e Produtos (DDPP) da Faculdade de Engenharia Química (FEQ) da UNICAMP. Tem experiência na área de Corrosão e Adsorção, com ênfase em Eletrodeposição de Ligas Metálicas e Remoção de Metais Tóxicos, atuando principalmente nos seguintes temas: eletrometria, ligas metálicas, argilas, caracterização de adsorventes e remoção de metais tóxicos. Desde 2014, vem atuando mormente na área de eletroquímica e corrosão.

\section{ANA CAROLINE FIRMIANO DE JESUS}

Possui ensino medio pelo Externato Santa Terezinha (2010). Atualmente é Estagiária da Peres Diesel Mercedez Bens. Tem experiência na área de Engenharia de Produção.

\section{ANA CLAUDIA DE MELO CALDAS BATISTA}

Possui graduação em Engenharia Mecânica pela Universidade Federal do Rio Grande do Norte (2012), graduação em Licenciatura plena em Física pelo Instituto Federal de Educação, Ciência e Tecnologia do Rio Grande do Norte (2007), Mestrado em Engenharia Mecânica pela Universidade Federal do Rio Grande do Norte (2013) e Doutorado pela Universidade Federal do Rio Grande do Norte (2017). Atualmente é professora efetiva da Universidade Federal Rural do Semi-Árido (UFERSA). Pesquisadora na área de Compósitos poliméricos

\section{ANDERSON MAIA}

Professor e Pesquisador no SENAI Mario Amato - SBC e no Centro Paula Souza, na área de Tecnologia e Engenharia de Polímeros, Engenharia de Embalagens. Atua no Instituto SENAI de Materiais Avançados e Nanocompósitos como Pesquisador e Coordenador no departamento de Relações com Indústria em projetos de plataforma Tecnológica. Graduado em Química pelo Centro Universitário Fundação Santo André. Mestre em Engenharia Mecânica - Fabricação de Materiais Unicamp e atualmente Doutorando do mesmo Departamento. Possui 25 anos de atividades relacionadas em Inovação e modificação de materiais aplicados em setores como embalagens, automotivo, eletrônico, têxtil e agronegócio. 


\section{ANDREA BETTANIN}

Possui graduação em Engenharia de Materiais pela Universidade Federal do Rio Grande do Sul (UFRGS). Tem experiência na área de reciclagem de Resíduos de Equipamentos Elétricos e Eletrônicos (REEE), em especial com resíduos de módulos fotovoltaicos de primeira geração. Atualmente é mestranda em Engenharia na área de Ciência e Tecnologia de Materiais pelo programa de pós-graduação em Engenharia de Minas, Metalúrgica e de Materiais (PPGE3M) da UFRGS. Atua na área de Materiais com ênfase em reciclagem de Resíduos Sólidos Urbanos (RSU), principalmente na linha de pesquisa: Processos de reciclagem de rejeitos de RSU oriundos da coleta seletiva.

\section{ANTONIA VANESSA VASCONCELOS MARTINS FROTA}

Graduada em engenharia química na Universidade Federal do Rio Grande do Norte. Tem experiência na área de Engenharia Química, com ênfase em Materiais.

\section{ASSIS VICENTE BENEDETTI}

Possui graduação em Licenciatura Em Química pela Fundação de Ensino e Tecnologia de Alfenas, Faculdade de Filosofia Ciências e Letras de Alfenas, atual UNIFENAS, Minas Gerais (1975), diploma registrado na Universidade Federal de Juiz de Fora (1980), Minas Gerais, graduação em Farmácia e Bioquímica pela Universidade Federal de Alfenas (1973), mestrado em Química (Físico-Química) pela Universidade de São Paulo (1977), doutorado em Química (Físico-Química) pela Universidade de São Paulo (1980) e pós-doutorado pela Universidade de Barcelona, Espanha (1990). Atualmente é professor titular aposentado e com vínculo como Professor Voluntário do Instituto de Química, Universidade Estadual Paulista Júlio de Mesquita Filho.

\section{BEATRIZ SEABRA MELO}

Acadêmica em Engenharia Mecânica da Universidade Federal do Pará. Técnica em Eletrotécnica formada pelo Instituto Federal de Educação, Ciência e Tecnologia do Pará. Integrante da Equipe Uirapuru Aerodesign na área de aerodinâmica e manufatura. Participante do Grupo de Pesquisas em Engenharia de Materiais atuante nas áreas de tribologia e ligas ferrosas e não-ferrosas.

\section{BRUNO APOLO MIRANDA FIGUEIRA}

Possui Graduação em Química Industrial pela Universidade Federal do Pará (2005), Doutorado Sandwiche (Brasil-Alemanha) em Ciências (Geoquímica) pela Universidade Federal do Pará e Martin Luther Universität (2012) e Pós doutorado em mineralogia e geoquímica pelo Museu Paraense Emílio Goeldi (2013) e Instituto de Geociências da UFPA (2014). É professor do Instituto de Engenharia e Geociências (IEG) da Universidade Federal do Oeste do Pará (UFOPA) e atualmente desenvolve pesquisa em química ambiental e de materiais. É coordenador de dois projetos financiados pelo CNPQ (Universal/2016) e Capes (Recém doutor/2015) em que aborda o reaproveitamento de rejeitos da mineração da Amazônia para obtenção de materiais de importância tecnológica. Atualmente coordena o Laboratório de Síntese e Caracterização de Materiais do Instituto de Geociências da UFOPA e participa como vice-coordenador do Programa de Pós Graduação em Sociedade, Ambiente e Qualidade de Vida (PPGSAQ/UFOPA).

\section{CAMILA PACELLY BRANDÃO DE ARAÚJO}

Graduada, mestre e doutora em Engenharia Química pela Universidade Federal do Rio Grande do Norte (2013, 2015 e 2018, respectivamente). Atualmente é Professora Adjunta (A1) do Magistério Superior na Universidade Federal do Rio Grande do Norte atuando na disciplina de Mecânica dos Fluidos para a Escola de Ciência e Tecnologia atuando nas áreas de simulação de arrasto sobre elementos aeroespaciais e desenvolvimento de materiais refratários para aplicações aeroespaciais. 


\section{CARLOS BRUNO BARRETO LUNA}

Mestre em Engenharia de Materiais pela Universidade Federal de Campina Grande (UFCG). Possui aperfeiçoamento em Engenharia de Segurança do Trabalho e Engenharia de Qualidade, sendo ambas pela Universidade Cândido Mendes (Rio de Janeiro). Durante a graduação foi bolsista PIBIC (2012-2013), (2013-2014) e (2014-2015). Tem experiência na área de engenharia de materiais e metalúrgica, com ênfase em materiais poliméricos, bem como participação em trabalhos com materiais cerâmicos tradicionais e biomaterial metálico. Atualmente doutorando em Ciência e Engenharia de Materiais pela UFCG (Conceito Capes 5).

\section{CARLSON PEREIRA DE SOUZA}

Graduado em Engenharia Quimica pela Universidade Federal do Rio Grande do Norte (1980), mestrado em Engenharia Mecânica com enfase em Extração Liquido-Liquido pela UFRN (1987) e doutorado em Engenharia Química - Université Claude Bernard - Lyon 1- INSA (1992), França. Pós Doutorado na Université de Toulon et du Var, Toulon, França (2000). Atualmente é professor Titular da UFRN, lotado no Departamento de Engenharia Quimica, participando como professor permanente nos programas de Pós-Graduação em Engenharia Química e Ciência e Engenharia de Materiais da UFRN. Além disso tem desenvolvido atividades como professor visitante na Université de Toulon et du Var, França. Tem experiência na área de Engenharia Química, com ênfase em Processos de Separação e Mistura, Termodinâmica dos Materiais, com ênfase em Nanociência/Nanotecnologia e Reatores Químicos.

\section{CARMEN IARA WALTER CALCAGNO}

Doutora em Ciência dos Materiais e mestre em Química pela Universidade Federal do Rio Grande do Sul. Desde 1998, atua como professora do Instituto Federal de Educação, Ciência e Tecnologia Sul-Rio-Grandense (IFSUL), no Campus Sapucaia do Sul, na região metropolitana de Porto Alegre, nas áreas de desenvolvimento, processamento e caracterização de materiais poliméricos e cerâmicos. Responsável pela criação e implantação do Laboratório de Desenvolvimento Integrado de Materiais e Produtos (DIMP).

\section{CECÍLIO SADAO FUGIVARA}

Possui graduação em Bacharelado em Química pela Universidade Estadual Paulista Júlio de Mesquita Filho (1982), mestrado em Química (Físico-Química) pela Universidade de São Paulo (1989) e doutorado em Química (Físico-Química) pela Universidade de São Paulo (1997). Atualmente é professor assistente doutor da Universidade Estadual Paulista Júlio de Mesquita Filho. Tem experiência na área de Química, com ênfase em Eletroquímica, atuando principalmente nos seguintes temas: inibidores voláteis de corrosão, revestimentos metálicos e permeação do hidrogênio em aços.

\section{CLÁUDIA CICERI CESA}

Professora de Educação Física (PUC-RS), Mestre e Doutora em Ciências da Saúde: Cardiologia (ICFUC). Professora EBTT do IFSul.

\section{CLAUDIO VICTOR DA SILVA E SILVA}

Estudante de Engenharia Mecânica da Universidade Federal do Pará.

\section{CLEONILSON MAFRA BARBOSA}

Possui graduação em Química-Licenciatura pela Universidade Federal do Rio Grande do Norte (UFRN). Especialista em Docência no Ensino Superior pela Universidade Potiguar (UnP). Mestre e Doutor em Ciências e Engenharia de Materiais pela UFRN. Realizou o doutorado sanduíche nos Estados Unidos, com duração de 1 ano, na Case Western Reserve University em Cleveland/Ohio no Eletronics Design Center sob orientação do Prof Dr. Chung Chiun Liu e atualmente realizando o PhD 
em Ciências e Engenharia de Materiais na UFRN. Desde o ano de 2010 é professor permanente de Processos Químicos no Instituto Federal do Rio Grande do Norte (IFRN), em regime de Dedicação Exclusiva lotado no Campus Natal Central.

\section{CLÓVIS IARLANDE OLIVEIRA SANTANA}

Mestrando em Engenharia Mecânica pela Universidade Federal do Pará, com linha de pesquisa em Processamento e Caracterização dos Materiais. Formado em Engenharia Mecânica pela Universidade Federal do Pará (2016). Participante do Grupo de Pesquisa Em Engenharia de Materiais - GPEMAT, atuando principalmente nas linhas de pesquisa: Tribologia, caracterização de materiais metálicos e metalurgia da transformação de ligas de Alumínio.

\section{DANIELLA GONCCALVES PORTELA}

Graduada em Engenharia Civil pela Universidade Tecnológica Federal do Paraná (2015). Possui graduação sanduíche em Engenharia Civil pela Universidade Nova de Lisboa (2013). Estagiou em empresas desenvolvendo laudos de pericias e avaliações (2015) e trabalhou com projeto hidrossanitários (2016). Concluiu o mestrado na Faculdade de Engenharia Química da Unicamp, em pesquisas para remoção de metais tóxicos de efluente industrial e formação de ligas metálicas anticorrosivas por eletrodeposição. Tem experiência na área de Engenharia Civil, com ênfase em corrosão e efluentes sintético e biológicos. Atualmente é doutoranda na Faculdade de Engenharia Civil da Unicamp, trabalhando com remoção de nitrogênio e processo Anammox.

\section{DAVID ROZA JOSÉ}

Professor do Ensino Básico, Técnico e Tecnológico do Instituto Federal Catarinense, Campus Luzerna. Mestre em Engenharia Mecânica (2014), na área de Análise e Projeto Mecânico, pela Universidade Federal de Santa Catarina - UFSC. Graduado em Engenharia Mecânica (2012) na Universidade do Estado de Santa Catarina - UDESC. Possui experiência na área de simulação numérica, tendo atuado com: Elementos Finitos, Mecânica do Dano, Pesquisa Estrutural e Fluidodinâmica Computacional.

\section{DAYANE IZABELITA SANTOS LACERDA}

Aluna de doutorado do Programa de Pós-Graduação em Química da Universidade Federal do Amazonas na área Físico-Química com ênfase em Química dos materiais (2014-2018). Possui graduação em Engenharia Química pela Universidade Federal do Pará (2000). Possui especialização em Óleos Vegetais pela Universidade Federal do Pará (2002). Possui Pós-graduação em Ciências na Área de Geoquímica e Petrologia pela Universidade Federal do Pará (2004).

\section{DOUGLAS DIAS DE OLIVEIRA}

Analista de Laboratório na Transcor Indústria de Pigmentos e Corantes. Possui Graduação em Polímeros pela FATEC-Mauá, Centro Estadual Paula Souza, onde realizou pesquisas de Iniciação Científica.

\section{DURVAL J. DE BARBA JR.}

Possui graduação em ENGENHARIA MECÂNICA pela Universidade Federal de Santa Catarina (1993), mestrado em Engenharia Mecânica pela Universidade Federal de Santa Catarina (1997) e doutorado em Engenharia Aeronâutica e Mecânica pelo Instituto Tecnológico de Aeronáutica (2015). Atualmente é professor do Instituto Federal Sul-Rio-Grandense. Tem experiência na área de Engenharia de Produção, com ênfase em Sustentabilidade, atuando principalmente nos seguintes temas: sustentabilidade, paredes finas, fabricação, life cycle assessment e usinagem. 


\section{EDCLEIDE MARIA ARAÚJO}

Possui graduação em Engenharia de Materiais pela UFPB (1991), mestrado em Engenharia Química na UFPB (1995) e doutorado em Ciência e Engenharia dos Materiais pela UFSCar (2001). Desde 2002, é professora do Curso de Graduação em Engenharia de Materiais na Universidade Federal de Campina Grande (UFCG). Orienta alunos de graduação, mestrado e doutorado. Supervisiona pesquisadores de pós-doutorado. Atua também como consultor Ad hoc do CNPq, como revisor e parecerista de vários periódicos indexados, bem como, de projetos. É membro do Conselho Diretor da Associação Brasileira de Polímeros (ABPol). É bolsista de produtividade em pesquisa do CNPq, nível 1D.

\section{EDUARDO AUGUSTO FLESCH}

Possui graduação em Engenharia Mecânica pela Universidade Federal de Santa Maria e mestrado pela Universidade Federal de Santa Catarina. Tem experiência na área de Engenharia Mecânica, com ênfase em Projeto de Sistemas Mecânicos.

\section{ELANDIR ANTONIO DESIDÉRIO}

Possui graduação em Engenharia de Produção Mecânica pela Universidade do Oeste de Santa Catarina (2006). Atualmente é PROFESSOR SUBSTITUTO do Instituto Federal Catarinense. Tem experiência na área de Engenharia Mecânica

\section{EMERSON DAVID CAVALCANTE SANTOS}

Possui graduação em Engenharia Mecânica pela Universidade Federal do Pará (2003), pósgraduação a nível de Especialização em Tecnologia Mineral e Metalurgia (2004) e Mestrado em Engenharia Mecânica na Área de Materiais e Processos de Fabricação, com ênfase em Desgaste de Metais (2013), ambos pela UFPA - Universidade Federal do Pará. Atualmente é Engenheiro de Manutenção Sênior na Albras - Alumínio Brasileiro S.A. Tem experiência na área de Engenharia de Materiais e Metalúrgica, com ênfase em Tratamentos Térmicos, Mecânicos e Químicos, atuando principalmente nos seguintes temas: liga 6101, propriedades mecânicas, envelhecimento natural, solidificação unidirecional e tratamento térmico.

\section{ENIO CÉSAR MACHADO FAGUNDES}

Professor do Instituto Federal de Educação, Ciência e Tecnologia Sul-Rio-Grandense (IFSUL) desde 2003. Atua nas áreas de Transformação de Termoplásticos, Elastômeros, Térmica e Técnicas Estatísticas Aplicadas. Possui experiência na indústria e em produção, na área de Polímeros.

\section{EVE MARIA FREIRE DE AQUINO}

Possui graduação em Engenharia Mecânica pela Universidade Federal da Paraíba, mestrado em Engenharia Mecânica pela Universidade Federal do Rio de Janeiro - COPPE e doutorado em Engenharia Industrial - Universidad Politécnica de Madrid. Atualmente é professor Titular da Universidade Federal do Rio Grande do Norte. Tem experiência na área de fadiga, mecanismo da fratura e comportamento mecânico com ênfase em Materiais Compósitos. Principais temas: Fadiga em compósitos poliméricos, fratura, concentração de tensões, envelhcimento ambiental, fibras naturais e sintéticas. Bolsista de produtividade PQ2

\section{FELIPE CANAL}

Graduando em Engenharia mecânica, tem experiência na área de produção mecânica, 


\section{FERNANDO MICHELON MARQUES}

Possui Doutorado em andamento em Engenharia de Minas, Metalurgia e Materiais pela Universidade Federal do Rio Grande do Sul (UFRGS), é Mestre em Engenharia de Minas, Metalurgia e Materiais pela Universidade Federal do Rio Grande do Sul- UFRGS (2012), possui Especialização em Psicopedagogia pela ESUCRI (2010) e possui graduação em Tecnologia em Eletromecânica pela Universidade do Extremo Sul Catarinense - UNESC (2004). Atualmente é professor de Nível Básico Técnico e Tecnológico do Instituto Federal de Santa Catarina IFSC-Campus Chapecó. Tem experiência na área de Engenharia Mecânica, com ênfase em Maquinas de Usinagem CNC, Convencionais e de Conformação, incluindo Sistemas Hidráulicos e Pneumáticos Industriais. Desenvolve projetos de pesquisa na área de usinagem e engenharia de superfície.

\section{FERNANDO PRANDO DACAS}

Engenheiro Mecânico com experiência na área de Manutenção Mecânica de motores e geradores de pequeno e médio porte, manutenção e certificação em motores para área classificada Exd e Ext, Manutenção industrial de empresas de fundição de chumbo e reciclagem de baterias, montagem e manutenção de redutores e moto-redutores, conhecimento nos processos de soldagem Mig/Mag, arame tubular e eletrodo revestido, sistemas de medição industrial, usinagem em trono convencional, operação e programação de torno CNC, e centro de usinagem.

\section{FLÁVIA STÜRMER DE FRAGA}

Graduanda em Química Industrial e Licenciatura (PUCRS). Tem experiência na degradação e biodegradação de polietileno via enzimática.

\section{GABRIELA LAGRANHA DE SOUZA}

Graduanda em Química Industrial (PUCRS). Tem experiência na degradação e biodegradação de polietileno via enzimática.

\section{GABRIELA MESSIAS MIRANDA}

Doutoranda no Programa de Pós-Graduação em Engenharia e Tecnologia de Materiais. Mestrado em Engenharia e Tecnologia de Materiais pela Pontifícia Universidade Católica do Rio Grande do Sul. Graduação em Engenharia Química na Pontifícia Universidade Católica do Rio Grande do Sul. Tem experiência na degradação e biodegradação de polietileno via enzimática, no desenvolvimento de nanodispersões aquosas de poliuretano com adição de cargas inorgânicas para aplicação em tintas especiais, em atendimentos a empresas alimentícias além de consultoria a essas empresas em boas práticas de fabricação, orçamentos, normas e legislações a cerca de análises microbiológicas e físico quimicas em alimentos, gestão do transporte de produtos perigosos em relação ao âmbito ambiental, além de atividades administrativas.

\section{GHISANA FEDRIGO}

Graduanda em Engenharia Mecânica pelo IFC- Instituto Federal Catarinense e fundadora da empresa Protus. Têm experiência em soldagem por fricção em ligas de alumínio, especialmente na liga Al7075. Têm experiência em tratamento térmico na liga de titânio Ti6AL4V-ELI. Atualmente é diretora técnica da Protus e também dedica-se a pesquisa de processos de fabricação e tratamento de superfícies em ligas de titânio para aplicação médica e odontológica

\section{GIOVANNA AMÁBILE DUARTE ROSA}

Assistente de Laboratório do SENAI Mario Amato - SBC. É graduada em Polímeros pela FATECMauá, Centro Estadual Paula Souza, onde realizou pesquisas de Iniciação Científica. Além desse, possui curso técnico em Química pelo SENAI Maio Amato. 


\section{GUSTAVO CÉSAR PAMPLONA DE SOUSA}

Engenheiro mecânico pela Universidade Federal de Campina Grande (2016), possui Mestrado (2019) em Engenharia Mecânica também pela UFCG. Atua na área de materiais aplicados às energias e processos de fabricação com enfoque em engenharia de superfície, superfícies solar seletivas, filmes finos, recursos renováveis, tratamentos termoquímicos e caracterização dos materiais.

\section{IRLANA COSTA DO MAR}

Possui graduação em Engenharia Física pela Universidade Federal do Oeste do Pará (2018) e graduação em Bacharelado interdisciplinar em Ciência e Tecnologia pela Universidade Federal do Oeste do Pará (2017), com estudos direcionados à área de Ciência dos Materiais e foco em síntese, caracterização e aplicação de nanomateriais.

\section{JEAN CARLO TAVARES}

Técnico em Manutenção Mecânica pela Escola Técnica Municipal "Os Padres do Trabalho" (2004), Engenheiro de Produção pela Universidade Presidente Antônio Carlos (2008) e especialista em Transporte Ferroviário de Carga pelo IME - Instituto Militar de Engenharia (2017). Atua no setor ferroviário desde 2004, acumulando experiência como técnico de manutenção, coordenador de equipes e atualmente como especialista ferroviário sênior, na empresa MRS Logística na Gerência Geral de Manutenção de Vagões. Tem experiência em análise de falhas, gestão de estoque, gestão de pessoas, gestão de processos gerenciais, gerenciamento pelas diretrizes (GPD), gerenciamento de rotina e auditorias de diversos segmentos como segurança do trabalho e processos de manutenção e operação.

\section{JEANE ESTELA AYRES DE LIMA}

Possui graduação em Engenharia Química pela Universidade Federal do Rio Grande do Sul (1993), mestrado em Química pela UFRGS (1996) e doutorado em Ciências pelo Programa de PósGraduação em Ciência dos Materiais pela UFRGS (2002). Atualmente é professora adjunto da Pontifícia Universidade Católica do Rio Grande do Sul. Tem experiência na área de Química, com ênfase em Cinética Química e Catálise, atuando principalmente nos seguintes temas: reciclagem de materiais, sequestro de carbono, biomassa e biocombustíveis.

\section{JÉSSICA PEREIRA PIRES}

Graduada em Engenharia Química (2016), e mestre em Engenharia e Tecnologias de Materiais (2019) pela Pontifícia Universidade Católica do Rio Grande do Sul. Pertenço ao Instituto do Petróleo e dos Recursos Naturais (IPR), onde as principais áreas da minha atuação são: biodegradação de plásticos comerciais, utilização de casca de banana para adsorção de metais pesados e análise de isótopos estáveis em vinhos e espumantes. Nestas áreas de pesquisa, estou habituada a realizar as caracterizações dos mesmos, utilizando diversas técnicas analíticas instrumentais, tais como: Infravermelho, Analisador Elementar, Espectrômetro de Massas de Razão Isotópica, Cromatógrafo a Gás, Análises termogravimétricas e Calorimetria Exploratória Diferencial.

\section{JHONATAS SANTOS MORAIS}

Atua no setor de qualidade da fundição na empresa Showa do Brasil LTDA, trabalhando no laboratório de análise química e controle de qualidade. Realizando análise química do alumínio, testes de flexão, dureza e tração. Possui graduação em Engenharia Mecânica na UNINORTE, cursando atualmente Pós-Graduação em Processos de Fabricação Mecânica. Possui participação em trabalhos de melhoria sobre nucleação do alumínio no processo de fundição da liga de alumínio A356. 


\section{JOÃO BAPTISTA DA COSTA AGRA DE MELO}

Possui graduação em Engenharia Mecânica pela UFPB (1986), especialização em Qualidade e Produtividade pela UFPB (1996), especialização em Especialização Em Higiene e Segurança no Trabalho pela UFPB (2000) e mestrado em Engenharia Mecânica pela UFPB (2001). Possui doutorado pela UFCG (2014) na área de Engenharia de Processos. Atualmente é Professor efetivo da Universidade Federal de Campina Grande.

\section{JOÃO DE DEUS PEREIRA DE MORAES SEGUNDO}

Possui graduação em Engenharia Mecânica pela Universidade do Estado do Amazonas (2013) e mestrado em Engenharia Mecânica pela Universidade Estadual de Campinas (2015). Atualmente faz doutorado em Engenharia Mecânica pela Universidade Estadual de Campinas (2015-2019) . Tem experiência na área de Engenharia Mecânica, com ênfase em Engenharia de Manufatura e Materiais, atuando na pesquisa para o desenvolvimento de novos materiais por meio de síntese de nanopartículas poliméricas e produção de fibras poliméricas na escala nano e submicrometro.

\section{JOSÉ COSTA DE MACÊDO NETO}

Possui graduação em Ciência e Engenharia de Materiais pela Universidade Federal de Campina Grande (UFCG, 2003), Mestrado em Ciência e Engenharia de Materiais pela Universidade Federal de Campina Grande (UFCG, 2006) e Doutorado em Engenharia Química pela Faculdade de Engenharia Química da Universidade Estadual de Campinas (FEQ/UNICAMP, 2011) . Atualmente é professor Doutor, Classe-Adjunto, Nível-C, da Escola Superior de Tecnologia da Universidade do Estado do Amazonas (EST/UEA). Tem experiência na área de Engenharia de Materiais e Metalúrgica, atuando principalmente nos seguintes temas: Solidificação rápida, nanocompósitos poliméricos e polimerização em emulsão.

\section{JOSÉ MANUEL RIVAS MERCURY}

Professor Titular EBTT (2017) do Departamento de Química do Instituto Federal do Maranhão (IFMA). Pós-doutorado em Mineralogia Aplicada no Instituto de Geociências da UFPA (2010). Doutorado em Química pela Universidade Autônoma de Madri, Espanha (2004). Mestrado em Engenharia Química pela Universidade Federal do Pará (1995). Especialização em Engenharia de Materiais pela Universidade Federal de São Carlos (1992). Graduação em Engenharia Química pela Universidade Federal do Pará (1987). Professor de EBTT atualmente docente e coordenador do programa de Pós-Graduação em Engenharia de Materiais (Mestrado) do IFMA, Bolsista de Produtividade em Pesquisa (BEPP) da Fundação de Amparo à Pesquisa e ao Desenvolvimento Científico e Tecnológico do Maranhão (FAPEMA), consultor ad hoc da FAPEMA e do Instituto Federal Farroupilha e Revisor cientifico das revistas: Revista Escola de Minas, Cerâmica, Extensão em Foco, Revista de Ensino de Engenharia, Journal of the American Ceramic Society, Industrial \& Engineering Chemistry Research e Journal of Thermal Analysis and Calorimetry. Membro efetivo da Academia Maranhense de Ciências. Tem experiência nas áreas de Operações Unitárias, Processamento de Materiais Cerâmicos, Caracterização de materiais, Tratamento de resíduos, cerâmica vermelha, Cimentos de aluminatos de cálcio e cimentos.

\section{JOSÉ MARIA DO VALE QUARESMA}

Possui graduação em Engenharia Mecânica pela Universidade Federal do Pará (1977), mestrado em Engenharia Mecânica pela Universidade Estadual de Campinas (1982), doutorado em Engenharia Mecânica pela Universidade Estadual de Campinas (1999) e Pós-Doutorado em Engenharia Mecânica pela Universidade stadual de Campinas (2006/2007). Atualmente é Professor Titular da Universidade Federal do Pará. Tem experiência na área de Engenharia de Materiais e Metalúrgica, com ênfase em Solidificação, atuando principalmente nos seguintes temas: condições de solidificação, solidificação unidirecional horizontal, caracterização estruturais, mecânicas e elétricas de ligas não ferrosas, liga 6101, 6201 e 7000 e coeficiente de transferência de calor na interface metal/molde; para produção de fios e cabos para transmissão [Tx] e distribuição [Dx] de 
energia elétrica. É coordenador do Grupo de Pesquisa Em Engenharia de Materiais - GPEMAT, atuando principalmente nas linhas de pesquisa: Tribologia, caracterização de materiais metálicos e metalurgia da transformação de ligas de Alumínio.

\section{JOSIEL BRUNO DE OLIVEIRA}

Monitor do Laboratório de Materiais e Processamento, (LabMatPro) atua no laboratório em projetos de extensão e pesquisa acadêmica, auxilia os alunos de graduação e pós-graduação a desenvolverem suas atividades no laboratório. Possui experiência em metalografia do aço e alumínio. Desenvolveu atividades para a empresa Caloi com através do estágio voluntário. Atualmente está cursando Engenharia de Materiais na Universidade do Estado do Amazonas (UEA).

\section{JOSUÉ BOAROLI}

Possui graduação em Tecnologia em Manutenção Industrial pela Faculdade SATC - FASATC. É especialista em caracterização de materiais metálicos fundidos.

\section{JULIANO ASSIS BARON ENGERROFF}

Possui graduação em Ciência e Engenharia de Materiais pela Universidade Federal de Santa Catarina (2013), mestrado em Ciência e Engenharia de Materiais pela Universidade Federal de Santa Catarina (2015). Atualmente doutorando em Ciência e Engenharia de Materiais pela Universidade Federal de Santa Catarina com foco na obtenção de ímãs de terras raras via técnicas de manufatura aditiva. Ao longo dos últimos anos, vem fazendo parte de projetos para estabilização da cadeia produtiva de terras raras no Brasil, matérias-primas essenciais para fabricação de ímãs permanentes. Possui experiência na área de Ciência e Engenharia de Materiais, com ênfase em Metalurgia do Pó, reciclagem de materiais eletrônicos, ímãs permanentes e magnetismo, manufatura aditiva e também na concepção de projetos de fábrica e análise de viabilidade econômica.

\section{KAMILA DA SILVA POMPEU}

Atualmente é estagiária na Empresa de Tecnologia e Informação do Estado do Pará, onde realiza projetos e análises relacionadas aos esforços mecânicos provocados sobre torres de telecomunicações. Também é bolsista e vice coordenadora de ensino no programa de educação tutorial - PET da Universidade Federal do Pará. Tem experiência acadêmica de pesquisa na área de materiais, em relação ao estudo do comportamento de ligas metálicas; $\mathrm{Na}$ área espacial, onde realiza análises de materiais para confecção de revestimentos de satélites; E na área estrutural, onde realiza análise de esforços mecânicos sobre torres.

\section{KAREN SEGALA}

Possui Bacharelado (1998) e Licenciatura plena (2000) em Química pelas Faculdades Oswaldo Cruz. Mestrado em Química (Físico-Química) pela Universidade de São Paulo (2003) e Doutorado em Química (Química Inorgânica) pela Universidade Federal de Santa Catarina (2009). Atualmente é Professora Adjunto II na Universidade Federal do Amazonas (UFAM) e pesquisador colaborador no Departamento de Engenharia de Materiais e de Bioprocessos da Faculdade de Engenharia Química da UNICAMP, atuando no desenvolvimento de nano e biomateriais aplicados nas áreas médica, ambiental, de fármacos e de cosméticos. Tem experiência na área de Química, com ênfase em Química Inorgânica Nanotecnológica, e em Nanobiotecnologia.

\section{LEANDRO DA CONCEIÇÃO MEDEIROS}

Atualmente cursando disciplinas de Mestrado em Engenharia Elétrica na UFSJ. Possui MBA em Gestão de Negócios pelo Ibmec (2013), graduação em Engenharia Elétrica pela Universidade Federal do Rio de Janeiro (1994). Atualmente é gerente geral de manutenção de locomotivas - MRS. 
Tem experiência na área de Engenharia de Transportes, com grande experiência Engenharia de Produção em processos industriais.

\section{LEONARDO DANTAS RODRIGUES}

Possui graduação em Engenharia Mecânica pela Universidade Federal do Pará (2004), mestrado em Engenharia Mecânica pela Pontifícia Universidade Católica do Rio de Janeiro (2007) e doutorado em Engenharia Mecânica também na PUC-Rio (2014), com tese intitulada "Aplicação da técnica DIC a espécimes com diferentes formas, materiais e gradientes de deformação". Tem experiência na área de Engenharia Mecânica, com ênfase em Análise de Tensões e Integridade estrutural. Em 2008 fundou a empresa PRIMA-7S Integridade Estrutural, da qual foi sócio até julho de 2014. Foi engenheiro do Instituto de Tecnologia da PUC-Rio de julho 2013 a julho 2014 e professor horista da PUC-Rio de março a julho de 2014. Desde julho de 2014 é professor adjunto efetivo do Instituto de Tecnologia da Universidade Federal do Pará. Desde 2015 coordena o Núcleo Avançado de Análise de Tensões, grupo de pesquisa que se decida a análises numéricas e experimentais de estruturas e ao estudo do comportamento mecânico de materiais

\section{LILIANE NOGUEIRA DA SILVA}

Possui graduação em Engenharia Química pela Universidade Federal do Pará (2011), mestrado em Geologia e Geoquímica pela Universidade Federal do Pará (2013) e doutorado em Geologia e Geoquímica pela Universidade Federal do Pará (2018). Tem experiência na área de Engenharia Química, com ênfase em Processos Inorgânicos

\section{LUCAS BARP}

Técnico em mecânica formado pelo SENAI de Luzerna-SC (2013). Engenheiro Mecânico formado pelo Instituto Federal Catarinense - Campus Luzerna (2013-2019). Possui experiência na área de P\&D - Pesquisa e Desenvolvimento de projetos, desenhos CAD, prototipagem, com atuação na empresa NMT - New Medical Techonology (2014-2015); Experiência na área de Manutenção Mecânica ( Corretiva, Preventiva e Preditiva) - Setor de PCM e Engenharia - Na empresa Laticínios Tirol - Estágio (2017); Atualmente acionista na empresa Foccosul Automação, na qual atua como gerente de projetos e produção mecânica. (Desde início de 2018). A empresa atua no ramo de manutenções e soluções industriais, desde o desenvolvimento de novos projetos (inovadores), fabricação e montagem de máquinas.

\section{LUCAS CARVALHO CRUZ}

Concluindo a graduação no curso de Engenharia de Materiais pela Universidade do Estado do Amazonas UEA - EST. Desenvolveu projetos de extensão aplicados ao Polo Industrial de Manaus (PIM) em diversas áreas no Laboratório de Materiais e Processamento (LabMatPro). Trabalhou em projeto de iniciação científica com compósitos reforçados com fibras, cerâmica indígena reforçada, extração de biossílica através de esponja de água doce e fundição de alumínio como bolsista FAPEAM. Já foi estagiário na área de injeção plástica na área da manutenção e no polo duas rodas na área de fundição de alumínio.

\section{LUIS HENRIQUE GUILHERME}

Possui graduação em Engenharia de Produção pela Universidade de Araraquara (2008), mestrado (2011) e doutorado (2017) em Ciências e Engenharia de Materiais pela Escola de Engenharia de São Carlos da Universidade de São Paulo (EESC-USP), e pós-doutorado em Físico-Química pelo Instituto de Química da Universidade Estadual Paulista - UNESP (2017-2018) com período de estágio técnico no departamento Corrosion \& Protection Centre - University of Manchester (UK). Atua há 15 anos no setor metal-mecânico no segmento de construções soldadas tais como tanques, trocadores de calor, vasos de pressão, tubulações industriais e estruturas metálicas. Ocupou cargos nos departamentos de engenharia de projeto, controle de qualidade e supervisão de fabricação / montagem. 


\section{LUÍSA ALBAN}

Tem formação em Engenharia Química pela Pontifícia Universidade Católica do Rio Grande do Sul e experiência complementar na Universidade de Birmingham City, Inglaterra. Atuou na área da pesquisa nos Laboratório de Química Analítica, de Processos Ambientais e de Organometálicos e Resinas da PUCRS. Além disso, tem experiência na Secretaria do Meio Ambiente de Porto Alegre e Petroquímica Braskem. Mestra em Engenharia e Tecnologia de Materiais pela PUCRS.

\section{LUIZ HENRIQUE CAVALCANTE DAMACENA}

Assistente de Sistema de Gestão da Qualidade na KRISOLL RESINAS PLÁSTICAS. Mestrando em Engenharia Mecânica, Materiais, Processos e Polímeros pela FEI. Possui Graduação em Polímeros pela FATEC-Mauá, Centro Estadual Paula Souza, onde realizou pesquisas de Iniciação Científica. Além desse, é Técnico em Qualidade pelo SENAI Almirante Tamandaré.

\section{MARCELO DEMETRIO DE MAGALHÃES}

Graduando de Engenharia de Materiais pela Universidade Federal de Santa Catarina. Iniciou suas atividades de Iniciação Científica (2016) atuando na área de materiais magnéticos. Possui experiência na área de Ciência e Engenharia de Materiais, com ênfase em suas atividades realizadas até o momento, como processamento de ímãs permanentes e magnetismo, manufatura aditiva e propriedades mecânicas de materiais como aço, cobre, alumínio e suas respectivas ligas.

\section{MARCONI ANDRADE FARIAS}

Possui graduação em Engenharia Mecânica pela Universidade Federal da Paraíba (1985), Licenciatura Plena em Matemática pela Universidade Estadual da Paraíba (1987) e mestrado em Engenharia Mecânica pela Universidade Federal da Paraíba (1994). Atualmente é Professor terceiro Grau da Universidade Federal de Campina Grande. Tem experiência na área de Engenharia Mecânica , com ênfase em Processos de Fabricação, atuando principalmente nos seguintes temas: Corrosão-fadiga, Proteção superficial, Estruturas offshore, Fraturas assistida pelo ambiente.

\section{MARCOS AKIRA D'ÁVILA}

Possui graduação em Engenharia de Materiais pela Universidade Federal de São Carlos (1994), mestrado em Engenharia Mecânica pela Universidade Federal de Santa Catarina (1997) e doutorado em Engenharia Química - University Of California At Davis (2003). Atualmente é professor no Departamento de Engenharia de Manufatura e Materiais da Faculdade de Engenharia Mecânica da UNICAMP. Possui experiência nas áreas de reologia, processamento e caracterização de polímeros, modelagem e simulação de processos. Atualmente atua em pesquisas em fabricação e caracterização de biomateriais poliméricos, reologia de polímeros naturais e simulação por CFD de fluidos viscoelásticos.

\section{MÁRCIA CRISTINA GOMES DE ARAÚJO LIMA}

Graduado em Engenharia de Produção -UNIVERSO- Universidade Salgado de Oliveira, PE, Brasil em 2016 . Pós Graduação em Engenharia de Segurança do Trabalho pela Faculdade Joaquim Nabuco, Recife, PE, Brasil em 2017. Pós Graduação em Ciências e engenharia dos Materiais pela Universidade do Estado do Amazonas, Manaus - AM em 2018. Mestranda em Ciências e Engenharia dos Materiais na área de Nano partículas (Antioxidantes) UFAM - Universidade Federal da Amazonas, AM, Brasil. Atualmente sua área de pesquisa está relacionada à degradação térmica dos Antioxidantes.

\section{MARIA ONEIDE SILVA DE MORAES}

Doutoranda em Química na linha de pesquisa Química de Materiais pela Universidade Federal do Amazonas (2015-2019). Mestra em Química na área de concentração Físico-Química pela Universidade Federal do Amazonas (2011-2013). Graduada em Bacharel em Química pela Universidade Federal do Amazonas (2007-2011). Competências e habilidades como Mestra no 
Programa de Pós-Graduação em Química (UFAM/AM). Competências e habilidades como Trainee nível mestre do Programa RHAE Trainee CNPq-IEL no Instituto SENAI de Inovação (ISI). Atuando com ênfase em Química Geral, Química Inorgânica, Química Orgânica, Físico-Química, Termodinâmica, Espectroscopia.

\section{MARIA VERONILDA MACEDO SOUTO}

Graduada em licenciatura em Química pela Universidade Federal de campina Grande (2011). Nesse período adquiriu experiência com na área de eletroquímica, com também na área e biocombustíveis. Também lecionou por dois anos na escola Estadual José Vitorino de Medeiros. Em seguida, ingressou no mestrado em ciências e engenharia de matérias na Universidade Federal do Rio. Nesse período atuou como pesquisadora na área de carbetos de metais refratários dopados. Este curso foi concluído em 2013. Doutora em Ciências e Engenharia de Materiais pela Universidade Federal do Rio Grande do Norte- UFRN. Atualmente atua na gestão de Escola Estadual José Vitorino de Medeiros na Cidade de Sossego-PB.

\section{MÁRIO WOLFART JUNIOR}

Possui graduação em Engenharia Metalúrgica - Departamento de Metalurgia (1993), mestrado na área de concentração de Ciência Tecnologia dos Materiais pelo curso do programa em Engenharia de Minas, Metalúrgica e de Materiais (1996) e Doutorado em Engenharia na área de concentração de Ciência Tecnologia dos Materiais pelo curso do programa em Engenharia de Minas, Metalúrgica e de Materiais (2002). Possui Graduação em Licenciatura para Educação Profissional e Tecnológ. Atualmente, é professor de nível básico, técnico e tecnológico do IFC - Instituto Federal de Educação, Ciência e Tecnologia Catarinense - Câmpus Luzerna - SC na área de Engenharia Mecânica e Técnico em Mecânica

\section{MATEUS FELIPE BALD}

Técnico em mecânica formado pelo SENAI de Concórdia-SC (2015). Atualmente é acadêmico no curso de Engenharia Mecânica no Instituto Federal Catarinense - Campus Luzerna (2016/2). Participou na Shell Eco-marathon (2017) e é bolsista em projetos de pesquisa financiados pelo Instituto Federal Catarinense.

\section{MATEUS FORTES CARVALHO}

Graduado em Engenharia Mecânica e atualmente mestrando em Engenharia Mecânica. Possui experiência acadêmica em mecânica dos sólidos, atuando com materiais compósitos, caracterização de materiais, ensaios e testes monitorados por extensometria e modelagem numérica para análises estruturais. Membro do Núcleo Avançado de Análise de Tensões da UFPA desde 2015, onde tem contribuido com novas pesquisas e com a capacitação de novos estudantes da engenharia.

\section{NEIMAR JOÃO BALAN}

Discente de Engenharia Mecânica no Instituto Federal Catarinense Campus Luzerna. Também é bolsista de pesquisa na mesma instituição. Tem experiência na área Metalmecânica.

\section{OSCAR JESUS FERNANDEZ CHOQUE}

Pós-doutorado em Geoquímica e Mineralogia na Universidade de Halle-Alemanha (2014), Doutorado em Geologia e Geoquímica pela Universidade Federal do Pará (2002). Professor temporário-pesquisador da Universidade Federal do Pará de 2002 a 2005. Especialista em Gemologia e em Tecnologias da Educação Atualmente e professor do Curso de Mestrado em Engenharia de Materiais, Curso de Engenharia de Materiais e Curso Técnico em Metalurgia do Instituto Federal do Pará. Tem experiência na área de Ciências dos Materiais, Engenharia Metalúrgica, Mineralogia Aplicada e Técnicas Analíticas. Atuação em processamento mineral e operações unitárias, extração metalúrgica e processametno de materiais residuais da indústria 
mínero-metalúrgica. Em 2008 tem criado o laboratório de caracterização de materiais LCM do IFPA, do qual é colaborador.

\section{PATRÍCIA TERESA DA LUZ}

Engenheira Química (1996), Mestre em Físico-Química pela Universidade Federal do Pará (2002) e Doutora em Físico- Química também pela Universidade Federal do Pará UFPA (2015). Trabalhou como Analista Ambiental na Secretaria Municipal de Meio Ambiente de Belém/PA onde desenvolveu atividades de licenciamento ambiental, fiscalização e regulamentação em seguida trabalho na empresa Terra Meio Ambiente, também como analista ambiental. Foi professora contratada da UEPA, CIABA e UFRA. Atualmente é professora de Química do Instituto Federal de Educação, Ciência e Tecnologia do Pará - IFPA, onde foi Chefa do Departamento de Ciências e Formação de Professores - DEPRO e Diretora de Ensino Substituta do IFPA Campus Belém (2018/2019). Ministra aulas nos cursos de Licenciatura em Química, Técnico em Química e Engenharia de Materiais, é Coordenadora do Laboratório de Química Pesquisa do IFPA. Atua nas áreas de Biocombustíveis e Biomassas Residuais, preparação de catalisadores e biocatalisadores, além de estudos com óleos e gorduras vegetais e biopolímeros. Está vinculado aos Programas de Pós-Graduação em Engenharia de Materiais (PPGQEMAT) e Programa de Pós-Graduação em Educação Profissional e Tecnológica (PROFEPT). Atualmente orienta 5 mestrados, 4 IC. Tem experiência na área de Química, com ênfase em Cinética Química e Catálise, atuando principalmente na síntese e caracterização de catalisadores heterogêneos.

\section{PAULO ANTÔNIO PEREIRA WENDHAUSEN}

Possui graduação em Engenharia Mecânica pela Universidade Federal de Santa Catarina (1987), mestrado em Engenharia Mecânica pela Universidade Federal de Santa Catarina (1990) e doutorado em Engenharia Mecânica - Technische Universitaet Dreden (1995). Atualmente é professor associado da Universidade Federal de Santa Catarina. Tem experiência na área de Engenharia de Materiais e Metalúrgica, com ênfase em Metalurgia de Pó, atuando principalmente nos seguintes temas: metalurgia do po, magnetismo, moldagem de pós por injeção, ímas e terrasraras.

\section{PERLA ALVES DE OLIVEIRA}

Graduada em Engenharia Mecânica pelo Centro Universitário do Norte (UNINORTE), Manaus - AM em 2012. Pós Graduada em Ciências e Engenharia dos Materiais pela Universidade do Estado do Amazonas, Manaus - AM em 2018.

\section{RAFAEL SOARES CARDOSO}

Graduando em engenharia mecânica, experiência acadêmica em mecânica dos sólidos e análise de tensões.

\section{RAPHAEL SIQUEIRA FONTES}

Doutorado em Engenharia Mecânica pela Universidade Federal do Rio Grande do Norte, Brasil(2018). Professor EBTT do Instituto Federal de Educação, Ciência e Tecnologia do Rio Grande do Norte

\section{RAQUEL ROSA DE SOUZA}

Engenheira Mecânica pelo IFSUL (Instituto Federal Sul-Rio-Grandense), Sapucaia do Sul (2019/1). Ênfase em materiais e estruturas na instituição SIGMA-CLERMONT pelo programa BRAFITEC/França com duração de dois semestres. Possui experiência em pesquisa e 
desenvolvimento de produtos e materiais através de projetos de iniciação científica. Atualmente trabalha na área de projetos e gestão de processos e pessoas na Metalúrgica São Francisco.

\section{RENATA DE SOUSA NASCIMENTO}

Geóloga formada pela Universidade Federal do Oeste do Pará em 2018 e mestre em mestrado interdisciplinar em Sociedade, Ambiente e Qualidade de Vida. Atualmente desenvolve trabalhos de caracterização tecnológica de rejeitos da mineração da Amazônia para transformação em produtos de valor agregados (nanomateriais). Possui experiência em técnicas como difração de raios-X, fluorescencia de raios-X, espectroscopia Raman e de Infravermelho e analise termica por TG-DSCDTA.

\section{REINALDO DE ALMEIDA RODRIGUES}

Está realizando graduação em Engenharia de Materiais pela Universidade do Estado do Amazonas UEA, possui curso técnico em Mecânica pelo Instituto Federal de Educação, Ciência e Tecnologia do Amazonas (IFAM). Atualmente é analista de qualidade na empresa Showa do Brasil Ltda. sendo responsável técnico no laboratório de metrologia/calibração/ensaios, atuando nas seguintes áreas:ensaios destrutivos e não destrutivos de materiais metálicos; calibração de equipamentos de medição; elaboração de documentação técnica

\section{RODRIGO CARDOSO COSTA}

Mestre em Engenharia pelo PPGE3M da UFRGS. Psicopedagogo Institucional pela UCB. Tecnólogo em Eletromecânica pela UNESC. Atualmente sou professor do Instituto Federal Catarinense. Área de concentração profissional: Fabricação Mecânica com ênfase em Processos de Soldagem.

\section{ROGÉRIO VESCIA LOUREGA}

Possui graduação em Química Industrial pela Universidade Federal de Santa Maria (1999), mestrado em Química pela Universidade Federal de Santa Maria (2002) e doutorado em Química pela Universidade Federal de Santa Maria (2006). Atuou como professor substituto na UFRGS (2007-2008) e atualmente sou professor adjunto na PUCRS - Pontifícia Universidade Católica do Rio Grande do Sul. Pertenço ao CEPAC - Centro de Excelência em Pesquisa e Inovação sobre Patróleo, Recursos Minerais e Armazenamento de Carbono, onde atuo como coordenador dos laboratorios em diversos projetos, destacando-se também pela interdisciplinariedade dos projetos em andamento. As principais áreas da minha atuação são: fontes não convencionais de energia relacionadas a combustíveis fósseis, como hidratos de gás e também geração de gases de síntese em camadas de carvão. Nestas 2 grandes áreas de pesquisa, atuo na síntese, utilizando reatores de alta pressão e diferentes escalas e caracterização dos mesmos, utilizando diversas técnicas analíticas, tais como: Difratômetro de Raios-X, ICP-OES, Infra vermelho, Analisadores Elementar (C, H, N, S), CG-IR-MS (Cromatógrafo a gás, com análise isotópica e espectrômetro de massas), CG-FID-TCDFPD, PTGA (analisador termogravimétrico a altas pressões).

\section{RONDES FERREIRA DA SILVA TORIN}

Professora e Pesquisadora na Faculdade de Tecnologia de Mauá (FATEC - Mauá), Centro Estadual de Educação Tecnológica Paula Souza - CPS. Possui graduação em Física pela UFMT, Mestrado em Ciência e Tecnologia de Materiais pela Unesp-Bauru, Doutora em Nanociências e Materiais Avançados pela UFABC, dois anos de Pós-Doutorado na área de Materiais poliméricos/ embalagens ativas - UFABC (2017). Tem experiência na área de Caracterização de materiais compósitos nanoestruturados; Reologia de polímeros; Estabilização e (bio)degradação de polímeros; Desenvolvimento de embalagens poliméricas ativas; Análise de radicais livres por Ressonância Paramagnética Eletrônica; Estudo de propriedades físico-químicas da matéria. 


\section{ROSANE ANGÉLICA LIGABUE}

Possui graduação em Química Industrial pela Universidade Federal do Rio Grande do Sul (1991), mestrado em Química pela Universidade Federal do Rio Grande do Sul (1995) e doutorado em Química pela Universidade Estadual Paulista Júlio de Mesquita Filho (2000). Possui pós-doutorado na Université de Bourgogne (2002). Atualmente é professor adjunto da Faculdade de Química e professor permanente do Programa de Pós-Graduação de Engenharia e Tecnologia de Materiais da Pontifícia Universidade Católica do Rio Grande do Sul. Tem experiência na área de química de materiais, com ênfase em compostos organometálicos, catálise e carbonatação em CO2 supercrítico, atuando principalmente nos seguintes temas: síntese de biopolímeros, síntese de dispersões aquosas poliméricas, nanopartículas poliméricas, nanocompósitos poliméricos, reciclagem química de polímeros, líquidos iônicos, captura e transformação do CO2.

\section{ROSEMEIRE DOS SANTOS ALMEIDA}

Possui graduação em Tecnologia Mecânica - Modalidade Projetos pela Faculdade de Tecnologia de São Paulo (2001), Mestrado em Ciência e Tecnologia de Materiais da Faculdade de Engenharia Química pela Universidade Estadual de Campinas - UNICAMP (2010), Doutorado em Materiais e Processos de Fabricação da Faculdade de Engenharia Mecânica pela Universidade Estadual de Campinas da UNICAMP (2014), Pós-doutorado em Materiais e Manufatura da Faculdade de Engenharia Mecânica pela Universidade Estadual de Campinas da UNICAMP (2016) e Pósdoutorado no Dpto. de Engenharia Mecânica da Escola Politécnica da Faculdade de Engenharia Mecânica, pela Pontifícia Universidade Católica do Paraná / PUC (2016).

\section{RUDYERE NASCIMENTO SILVA}

Atualmente atua como Professor do Ensino Básico, Técnico e Tecnológico no Instituto Federal de Educação, Ciência

\section{RUTH MARLENE CAMPOMANES SANTANA}

Formada em Engenharia Química na Universidade Nacional Mayor de San Marcos-UNMSM,(1988), Lima-Perú. Realizou o mestrado e o doutorado na UNICAMP (1993-1999), Pós-doutorado no PPGCEM da UFSCar (1999-2004). Foi docente no Departamento de Engenharia Ambiental da UNISC, RS. Atualmente, é docente no Departamento de Materiais da Universidade Federal do Rio Grande do Sul, UFRGS/RS. Bolsista de Produtividade em Pesquisa PQ nível 2 (2012-2015). Participou em vários projetos financiados pelo CNPq, FAPESP; PROCAD, PROADEFAPERG, QUATTOR, BRASKEM, PAQUETÁ, SIBRATEC entre outros. Participa também em projetos de pesquisa com as universidades, UCS, UNIVILLE e UFMT. Trabalha na área de Materiais com ênfase em Polímeros, atuando principalmente nas seguintes linhas de pesquisa: Reciclagem de resíduos sólidos com ênfase em polímeros; Degradação abiótica e biótica de polímeros; Polímeros biodegradáveis; Processamento de termoplásticos e compósitos poliméricos; Funcionalização de polímeros hidrofóbicos para promover adesão; Desenvolvimento de espumas de PU ecológicas entre os mais importantes. Possui mais de 300 publicações de trabalhos completos entre artigos em revistas e eventos científicos nacionais e internacionais.

\section{SÉRGIO RENAN LOPES TINÔ}

Possui graduação em Engenharia Mecânica pela Universidade Federal do Rio Grande do Norte (2008), graduação em TECNOLOGIA EM MATERIAIS pelo CENTRO FEDERAL DE EDUCAÇÃO TECNOLÓGICA DO RIO GRANDE DO NORTE (2004), mestrado em Engenharia Mecânica pela Universidade Federal do Rio Grande do Norte (2010) e doutorado em Engenharia Mecânica pela Universidade Federal do Rio Grande do Norte (2014). Atualmente é professor do Instituto Federal de Educação, Ciência e Tecnologia de Goiás. Tem experiência na área de Engenharia Mecânica, com ênfase em Engenharia Mecânica/Materiais, atuando principalmente nos seguintes temas: mecânica dos sólidos e materiais compósitos 


\section{TAINAH VASCONCELOS PESSOA}

Graduanda em Engenharia Mecânica pelo Instituto Federal do Amazonas-IFAM (2016-2020). Técnica em Química pelo Instituto Federal do Amazonas - IFAM (2013-2015). Voluntária no Programa Institucional de Bolsas de Iniciação Científica (PIBIC) na Universidade Federal do Amazonas (2017/2018) em projetos que envolvem Polímero Molecularmente Impresso e produção de Nanofibras Poliméricas. Bolsista Programa Institucional de Bolsas de Iniciação Científica (PIBIC/CNPq) no Instituto Federal do Amazonas (2018/2019) em projetos que envolvem produção Nanofibras Poliméricas.

\section{THALES ANTÔNIO AMARANTE}

Técnico em Química pela Escola Técnica Estadual Conselheiro Antônio Prado. Cursando Engenharia Química pela Universidade Estadual de Campinas (Conclusão prevista para 2019). Tem experiência na área de Corrosão, com ênfase em Eletrodeposição de Ligas Metálicas, tendo desenvolvido dois projetos de iniciação científica nesta área, incluindo ligas de $\mathrm{Zn}-\mathrm{Ni}$ e CuNi. Estagiário em Manutenção e Projetos na empresa Lubrizol do Brasil Aditivos - Paulínia, desde 2017.

\section{THAYANE CARPANEDO DE MORAIS NEPEL}

Graduada em Química, com ênfase Tecnológica, pela Universidade Federal de Viçosa-UFV (2010) e Licenciatura em Química pela UFV (2010). Mestre em Ciências, na área Físico-Química, pelo Instituto de Química de São Carlos (IQSC-USP) (2012), desenvolvendo catalisadores anódicos para célula combustível. Concluiu o doutorado na Faculdade de Engenharia Química da Unicamp (2019), com pesquisa para remoção de metais tóxicos de efluente industrial e formação de liga metálica $\mathrm{NiCu}$ anticorrosivas, por eletrodeposição. Tem experiência em Química com ênfase nas áreas de Eletroquímica, Corrosão e Química Orgânica, atuando principalmente no desenvolvimento de novos produtos e instrumentação laboratorial.

\section{THIAGO FARIAS BUJES}

Médico Ortopedista e Traumatologista Especialista em Traumatologia do Esporte.

\section{THIAGO MONTEIRO MAQUINÉ}

Graduado em Engenharia Mecânica pela Universidade do Estado do Amazonas, Manaus - AM em 2009. Pós Graduado em Engenharia de Segurança do Trabalho pela UNINORTE, Manaus - AM em 2012. Pós Graduado em Ciências e Engenharia dos Materiais pela Universidade do Estado do Amazonas, Manaus - AM em 2018. Atualmente é coordenador de engenharia na área de construção naval, gasoduto com ênfase em processo de soldagem.

\section{VINICIUS DA SILVA REIS}

Graduando em Engenharia Mecânica, atualmente exercendo pesquisas no Grupo de Pesquisa em Engenharia de Materiais, atuando nas áreas de caracterização de matérias metálicos ferrosos e não ferrosos, tribologia. Além disso, bolsista do projeto CATEDRA/Vale.

\section{WALDEIR SILVA DIAS}

Atualmente é bolsista de iniciação cientifica da Fundação de Amparo a Pesquisa do Estado do Amazonas. Empenhado em desenvolver novos materiais e em investigar as propriedades e características dos materiais. Tem experiência na área de Engenharia de Materiais e Metalúrgica, com ênfase em Engenharia de Materiais, atuando principalmente nos seguintes temas: materiais cerâmicos, materiais poliméricos, compósitos com fibras naturais, biocompósitos e análises metalográficas. 


\section{WALLISSON ALVES DA SILVA}

Graduando em Engenharia Mecânica pela Universidade Federal de Campina Grande (previsão de término para 2020) . Membro do Programa de Educação Tutorial, possuindo experiências acadêmicas em ensino, pesquisa e extensão em nível de graduação. Além de razoável conhecimento nas áreas de Engenharia de Projetos e Engenharia de Materiais.

\section{WALTER RICARDO BRITO}

Possui graduação em Ciências Químicas (2000) pela Universidade de Oriente, Santiago de Cuba, Cuba. Mestrado em Química Inorgânica (Menção em Química de Estado Sólido)(2004) pela Faculdade de Química da Universidade da Havana, Havana, Cuba. Doutorado em Ciências, em Química (2010), pela Universidade Federal do Rio de Janeiro, Instituto de Química, Departamento de Físico - Química. Tem experiência na área de Química com ênfase em Ciência de Materiais, Química de Materiais e Físico-Química, nos temas: estudos de fotodegradação de dispositivos orgânicos emissores de luz (OLED), técnicas de caracterização espectroscópica como dessorção iônica induzida por impacto de elétrons e fótons, dessorção iônica induzida por laser, assim como estudos de superfícies empregando luz síncrotron, fotoabsorção e fotoemissão de luz síncrotron em matéria condensada, filmes finos, tecnologias de vácuo, espectrometria de massa, tratamento de materiais com micro-ondas, caracterização de materiais mediante técnicas de analise térmico, difração de raios $\mathrm{X}$, espectroscopia infravermelha com transformada de Fourier. Experiencia em processo de acreditação de Laboratório em norma ISO/IEC 17025 e implementação de ISO 9001 em sistema de Gestão da Qualidade em laboratórios. Atua no desenvolvimento e caracterização de sensores bioeletrônicos e dispositivos fotovoltaicos. Coordena projetos de pesquisa relacionados com o desenvolvimento de sensores, funcionalização de materiais e dispositivos fotovoltaicos. Líder do grupo de Pesquisa em Bioeletrônica, dispositivos fotovoltaicos e química de Materiais e coordenador do Laboratório de Bioeletrônica - LABEL da Central Analítica da UFAM. 


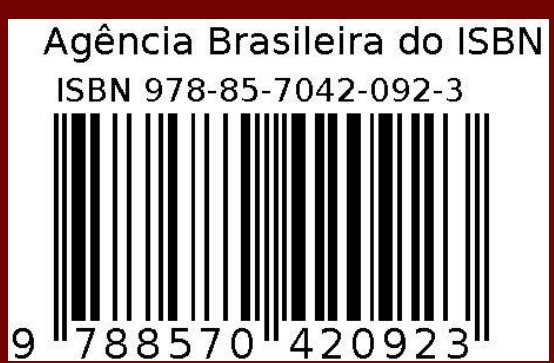

